Prepared in cooperation with the U.S. Navy

\title{
Geophysical and Video Logs of Selected Wells at and near the Former Naval Air Warfare Center Warminster, Bucks County, Pennsylvania, 2017-19
}

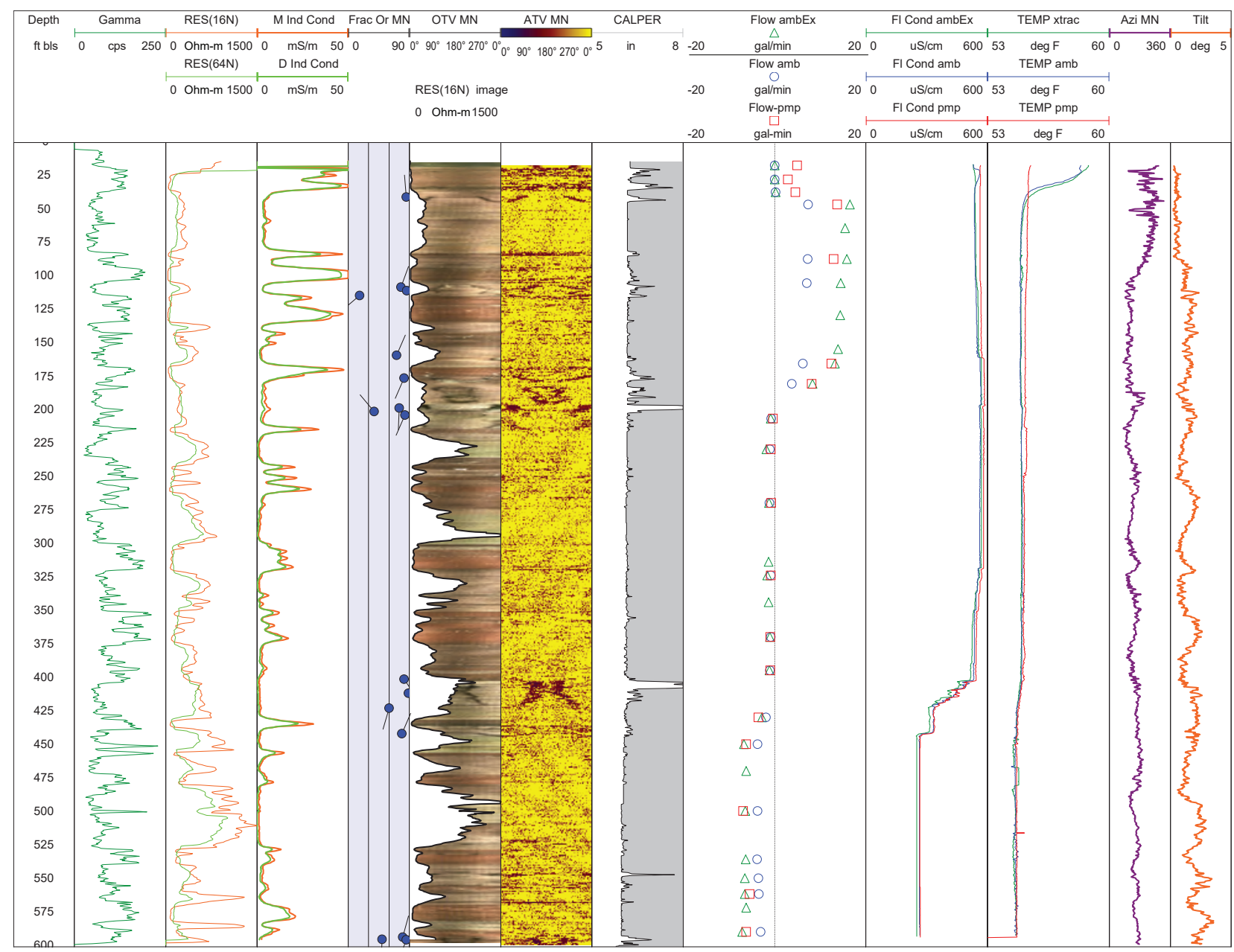

Open-File Report 2021-1025 
Cover: Geophysical logs collected by the U.S. Geological Survey in well BK-3063 (Navy well HN-116), Warminster Township, Bucks County, Pennsylvania, May 24-25, 2018. 


\section{Geophysical and Video Logs of Selected Wells at and near the Former Naval Air Warfare Center Warminster, Bucks County, Pennsylvania, 2017-19}

By Lisa A. Senior, J. Alton Anderson, and Philip H. Bird

Prepared in cooperation with the U.S. Navy

Open-File Report 2021-1025 


\section{U.S. Geological Survey, Reston, Virginia: 2021}

For more information on the USGS - the Federal source for science about the Earth, its natural and living resources, natural hazards, and the environment—visit https://www.usgs.gov or call 1-888-ASK-USGS.

For an overview of USGS information products, including maps, imagery, and publications, visit https://store.usgs.gov/.

Any use of trade, firm, or product names is for descriptive purposes only and does not imply endorsement by the U.S. Government.

Although this information product, for the most part, is in the public domain, it also may contain copyrighted materials as noted in the text. Permission to reproduce copyrighted items must be secured from the copyright owner.

Suggested citation:

Senior, L.A., Anderson, J.A., and Bird, P.H., 2021, Geophysical and video logs of selected wells at and near the former Naval Air Warfare Center Warminster, Bucks County, Pennsylvania, 2017-19: U.S. Geological Survey Open-File Report 2021-1025, 92 p., https://doi.org/10.3133/ofr20211025.

ISSN 2331-1258 (online) 


\section{Acknowledgments}

The support of U.S. Navy personnel and their contractors, Battelle Memorial Institute and Tetra Tech Incorporated, is gratefully acknowledged. Data and other technical support, as well as permission to access wells from the Warminster Township Municipal Authority, Warwick Township Water and Sewer Authority, Northampton Bucks County Municipal Authority, and Ivyland Borough is appreciated.

Numerous U.S. Geological Survey colleagues provided assistance to the project, including Dennis W. Risser for assistance in geophysical log archiving, and Mark Kozar and John Williams for colleague technical reviews. 



\section{Contents}

Acknowledgments ……...................................................................................................................

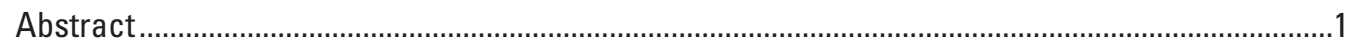

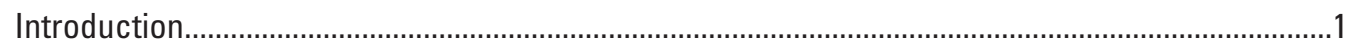

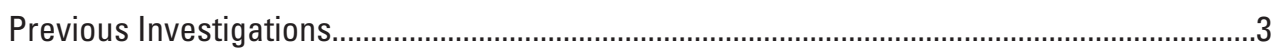

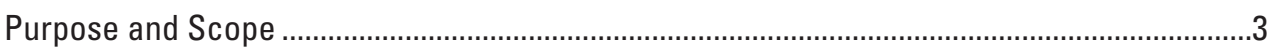

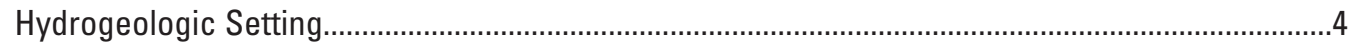

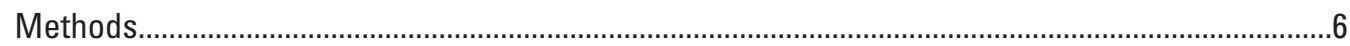

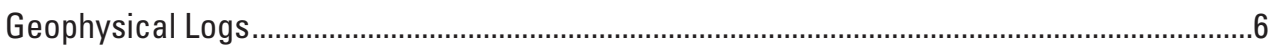

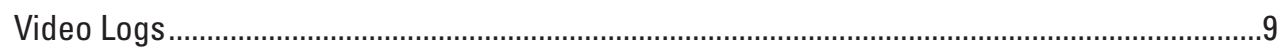

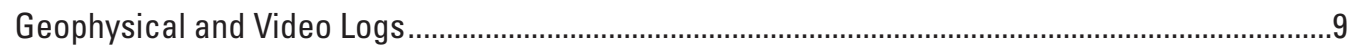

Interpretation of Individual Well Geophysical and Video Logs ...............................................12

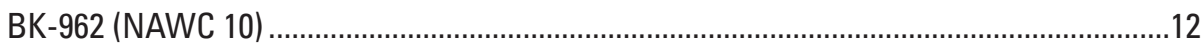

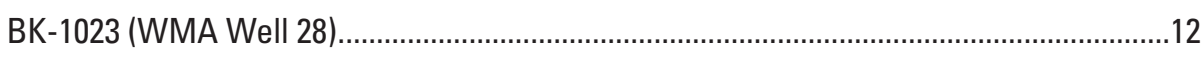

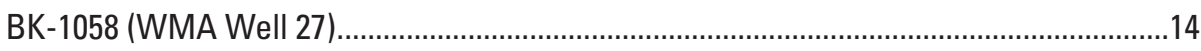

BK-1087 (WMA Well 25) ......................................................................................

BK-1129 (Warminster Well 36) ..................................................................................

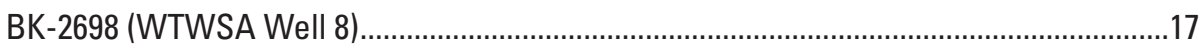

BK-2861 (WTWSA Well 11) ...................................................................................17

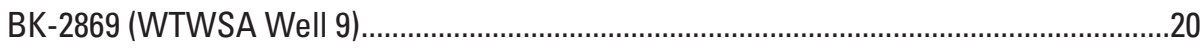

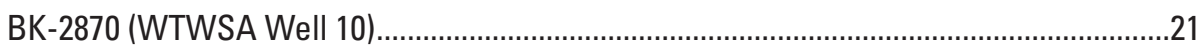

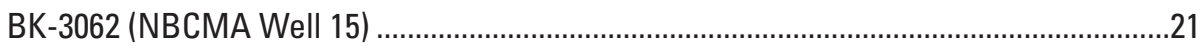

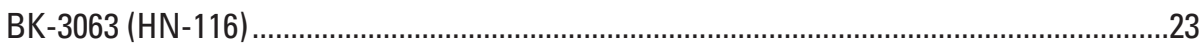

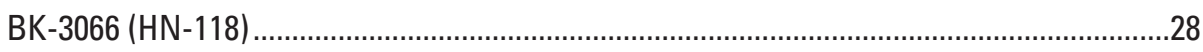

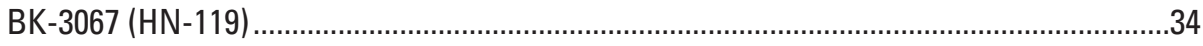

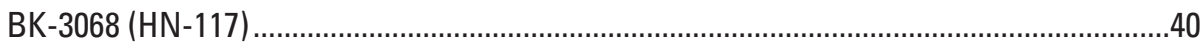

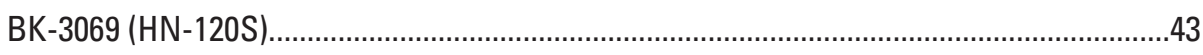

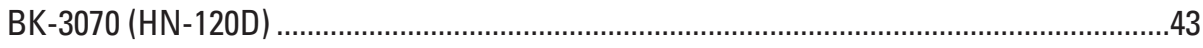

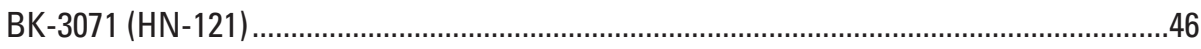

Discussion of Log Lithology, Fracture Orientation, Borehole Deviation, and Borehole-flow Directions............................................................................................48

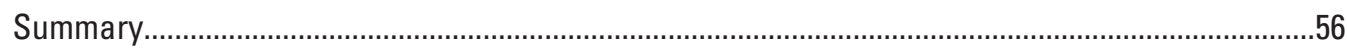

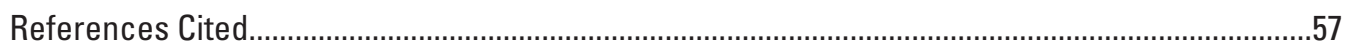

Appendix 1. Orientation of Selected Water-bearing Fractures in Wells......................................61

Appendix 2. Deviation and Drift of Boreholes .............................................................................77

\section{Figures}

1. Location of former Naval Air Warfare Center Warminster, former Naval Air Station Joint Reserve Base Willow Grove, and active Horsham Air Guard Station, land-surface elevations, streams, and location of wells with geophysical and video logs collected by U.S. Geological Survey near NAWC Warminster during 2017-19, Bucks and Montgomery Counties, Pennsylvania................2

2. Physiographic provinces of Pennsylvania and sections in study area in southeastern Pennsylvania. 
3. Mapped geology, including bedrock geologic units, that underlie the study area and bedding orientations in the Stockton Formation, as well as streams, location of wells with geophysical and video logs collected by U.S. Geological Survey near former Naval Air Warfare Center Warminster during 2017-19, and selected U.S. Geological Survey observation wells, Bucks and Montgomery Counties, Pennsylvania.

4. Geophysical logs collected by U.S. Geological Survey in well BK-962, Warminster Township, Bucks County, Pennsylvania, December 1, 2017 .........................13

5. Still images from borehole video log of well BK-962 ….............................................15

6. Geophysical logs collected by U.S. Geological Survey in well BK-1023, Warminster Township, Bucks County, Pennsylvania, September 6, 2018 .......................16

7. Still images from borehole video log of well BK-1023 ……..............................................18

8. Geophysical logs collected by U.S. Geological Survey in well BK-1087, Warminster Township, Bucks County, Pennsylvania, August 10, 2018 ...........................19

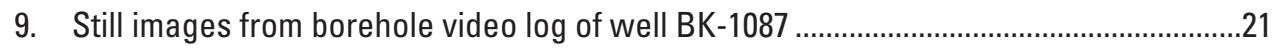

10. Geophysical logs collected by U.S. Geological Survey in well BK-1129, Warminster Township, Bucks County, Pennsylvania, September 5, 2018 ........................22

11. Still images from borehole video log of well BK-1129 ....................................................24

12. Geophysical logs collected by U.S. Geological Survey in well BK-2698, Warwick Township, Bucks County, Pennsylvania, September 10, 2019.....................................25

13. Still images from borehole video log of well BK-2698 .................................................26

14. Geophysical logs collected by U.S. Geological Survey in well BK-2861, Warwick Township, Bucks County, Pennsylvania, September 12, 2019 ..........................................27

15. Still images from borehole video log of well BK-2861 .................................................28

16. Geophysical logs collected by U.S. Geological Survey in well BK-2869, Warwick Township, Bucks County, Pennsylvania, June 16-17, 2019 .............................................29

17. Still images from borehole video log of well BK-2869 .....................................................30

18. Geophysical logs collected by U.S. Geological Survey in well BK-2870, Warwick Township, Bucks County, Pennsylvania, September 11, 2019.......................................31

19. Still images from borehole video log of well BK-2870 ….............................................32

20. Geophysical logs collected by U.S. Geological Survey in well BK-3062, Northampton Township, Bucks County, Pennsylvania, November 28-29, 2017 ..............33

21. Still images from borehole video log of well BK-3062 .....................................................35

22. Geophysical logs collected by U.S. Geological Survey in well BK-3063, Warminster Township, Bucks County, Pennsylvania, May 24-25, 2018 ...........................36

23. Still images from borehole video log of well BK-3063 .....................................................38

24. Geophysical logs collected by U.S. Geological Survey in well BK-3066, Warminster Township, Bucks County, Pennsylvania, August 6-7, 2018..........................39

25. Still images from borehole video log of well BK-3066 ...................................................41

26. Geophysical logs collected by U.S. Geological Survey in well BK-3067, Warminster Township, Bucks County, Pennsylvania, August 8, 2018.............................42

27. Still images from borehole video log of well BK-3067 ....................................................4

28. Geophysical logs collected by U.S. Geological Survey in well BK-3068, Warminster Township, Bucks County, Pennsylvania, August 9, 2018..............................45

29. Still images from borehole video log of well BK-3068 ....................................................

30. Still images from borehole video log of well BK-3069 ...................................................4

31. Geophysical logs collected by U.S. Geological Survey in well BK-3070, Warminster Township, Bucks County, Pennsylvania, October 31, 2018. 
32. Still images from borehole video log of well BK-3070

33. Geophysical logs collected by U.S. Geological Survey in well BK-3071, Warminster Township, Bucks County, Pennsylvania, November 1, 2018. .51

34. Still images from borehole video log of well BK-3071

\section{Tables}

1. Description of geophysical logs, reporting units, and abbreviations for logs collected by U.S. Geological Survey at and near Naval Air Warfare Center Warminster, Bucks County, Pennsylvania, 2017-19.

2. Characteristics of wells with geophysical and video logs collected by U.S. Geological Survey at and near the former Naval Air Warfare Center (NAWC) Warminster, Bucks County, Pennsylvania, 2017-19.

3. Type and dates of geophysical and video logs collected and archived by U.S. Geological Survey at and near Naval Air Warfare Center Warminster, Bucks County, Pennsylvania, 2017-19.

4. Borehole flow-measurements collected by U.S. Geological Survey in well BK-962, Warminster Township, Bucks County, Pennsylvania, December 1, 2017 ...........14

5. Borehole flow-measurements collected by U.S. Geological Survey in well BK-1023, Warminster Township, Bucks County, Pennsylvania, September 6, 2018 ........17

6. Borehole flow-measurements collected by U.S. Geological Survey in well BK-1087, Ivyland Borough, Bucks County, Pennsylvania, August 10, 2018.

7. Borehole flow-measurements collected by U.S. Geological Survey in well BK-1129, Warminster Township, Bucks County, Pennsylvania, September 5, 2018 .......23

8. Borehole flow-measurements collected by U.S. Geological Survey in well BK-2698, Warwick Township, Bucks County, Pennsylvania, September 10, 2019..........26

9. Borehole flow-measurements collected by U.S. Geological Survey in well BK-2861, Warwick Township, Bucks County, Pennsylvania, September 12, 2019...........28

10. Borehole flow-measurements collected by U.S. Geological Survey in well BK-2869, Warwick Township, Bucks County, Pennsylvania, June 16-17, 2019.

11. Borehole flow-measurements collected by U.S. Geological Survey in well BK-2870, Warwick Township, Bucks County, Pennsylvania, September 11, 2019

12. Borehole flow-measurements collected by U.S. Geological Survey in well BK-3062, Northampton Township, Bucks County, Pennsylvania, November 28-29, 2017

13. Borehole flow-measurements collected by U.S. Geological Survey in well BK-3063, Warminster Township, Bucks County, Pennsylvania, May 24-25, 2018. .37

14. Borehole flow-measurements collected by U.S. Geological Survey in well BK-3066, Warwick Township, Bucks County, Pennsylvania, August 6-7, 2018

15. Borehole flow-measurements collected by U.S. Geological Survey in well BK-3067, Northampton Township, Bucks County, Pennsylvania, August 8, 2018

16. Borehole flow-measurements collected by U.S. Geological Survey in well BK-3068, Warminster Township, Bucks County, Pennsylvania, August 9, 2018

17. Borehole flow-measurements collected by U.S. Geological Survey in well BK-3070, Warminster Township, Bucks County, Pennsylvania, October 31, 2018 ...........50

18. Borehole flow-measurements collected by U.S. Geological Survey in well BK-3071, Warminster Township, Bucks County, Pennsylvania, November 1, 2018. 
19. Summary of borehole deviation logs, directions of borehole flow, land-surface elevations at well heads, and other characteristics for wells logged by U.S. Geological Survey at and near the former Naval Air Warfare Center Warminster during 2017-19, Bucks County, Pennsylvania

\section{Conversion Factors}

U.S. customary units to International System of Units

\begin{tabular}{|c|c|c|}
\hline Multiply & By & To obtain \\
\hline \multicolumn{3}{|c|}{ Length } \\
\hline inch (in.) & 2.54 & centimeter $(\mathrm{cm})$ \\
\hline inch (in.) & 25.4 & millimeter (mm) \\
\hline foot $(\mathrm{ft})$ & 0.3048 & meter $(\mathrm{m})$ \\
\hline mile (mi) & 1.609 & kilometer $(\mathrm{km})$ \\
\hline \multicolumn{3}{|c|}{ Area } \\
\hline acre & 0.4047 & hectare (ha) \\
\hline acre & 0.004047 & square kilometer $\left(\mathrm{km}^{2}\right)$ \\
\hline square mile $\left(\mathrm{mi}^{2}\right)$ & 259.0 & hectare (ha) \\
\hline square mile $\left(\mathrm{mi}^{2}\right)$ & 2.590 & square kilometer $\left(\mathrm{km}^{2}\right)$ \\
\hline \multicolumn{3}{|c|}{ Flow rate } \\
\hline gallon per minute (gal/min) & 0.06309 & liter per second $(\mathrm{L} / \mathrm{s})$ \\
\hline \multicolumn{3}{|c|}{ Specific capacity } \\
\hline gallon per minute per foot ([gal/min $] / \mathrm{ft})$ & 0.2070 & liter per second per meter $([\mathrm{L} / \mathrm{s}] / \mathrm{m})$ \\
\hline
\end{tabular}

System of Units to U.S. customary units

\begin{tabular}{|c|c|c|}
\hline Multiply & By & To obtain \\
\hline \multicolumn{3}{|c|}{ Length } \\
\hline centimeter $(\mathrm{cm})$ & 0.3937 & inch (in.) \\
\hline millimeter (mm) & 0.03937 & inch (in.) \\
\hline meter (m) & 3.281 & foot $(\mathrm{ft})$ \\
\hline kilometer (km) & 0.6214 & mile (mi) \\
\hline \multicolumn{3}{|c|}{ zArea } \\
\hline hectare (ha) & 2.471 & acre \\
\hline square kilometer $\left(\mathrm{km}^{2}\right)$ & 247.1 & acre \\
\hline hectare (ha) & 0.003861 & square mile $\left(\mathrm{mi}^{2}\right)$ \\
\hline square kilometer $\left(\mathrm{km}^{2}\right)$ & 0.3861 & square mile $\left(\mathrm{mi}^{2}\right)$ \\
\hline \multicolumn{3}{|c|}{ Flow rate } \\
\hline liter per second $(\mathrm{L} / \mathrm{s})$ & 15.85 & gallon per minute (gal/min) \\
\hline \multicolumn{3}{|c|}{ Specific capacity } \\
\hline liter per second per meter $([\mathrm{L} / \mathrm{s}] / \mathrm{m})$ & 4.831 & gallon per minute per foot $([\mathrm{gal} / \mathrm{min}] / \mathrm{ft})$ \\
\hline
\end{tabular}

Temperature in degrees Celsius $\left({ }^{\circ} \mathrm{C}\right)$ may be converted to degrees Fahrenheit $\left({ }^{\circ} \mathrm{F}\right)$ as follows: ${ }^{\circ} \mathrm{F}=\left(1.8 \times{ }^{\circ} \mathrm{C}\right)+32$.

Temperature in degrees Fahrenheit $\left({ }^{\circ} \mathrm{F}\right)$ may be converted to degrees Celsius $\left({ }^{\circ} \mathrm{C}\right)$ as follows: ${ }^{\circ} \mathrm{C}=\left({ }^{\circ} \mathrm{F}-32\right) / 1.8$. 


\section{Datum}

Vertical coordinate information is referenced to the North American Vertical Datum of 1988 (NAVD 88).

Horizontal coordinate information is referenced to the North American Datum of 1983 (NAD 83).

Altitude, as used in this report, refers to distance above the vertical datum.

\section{Supplemental Information}

Specific conductance is given in microsiemens per centimeter at 25 degrees Celsius $\left(\mu \mathrm{S} / \mathrm{cm}\right.$ at $\left.25^{\circ} \mathrm{C}\right)$.

Concentrations of chemical constituents in water are given in either milligrams per liter (mg/L), micrograms per liter $(\mu \mathrm{g} / \mathrm{L})$, or nanograms per liter $(\mathrm{ng} / \mathrm{L})$, which are equivalent to parts per million (ppm), parts per billion (ppb), and parts per trillion (ppt), respectively. 


\title{
Selected Abbreviations
}

\author{
ANG Air National Guard \\ ATV acoustic televiewer \\ DOD U.S. Department of Defense \\ EPA U.S. Environmental Protection Agency \\ HAGS Horsham Air Guard Station \\ LHA Lifetime Health Advisory \\ NAD 83 North American Datum of 1983 \\ NASJRB (former) Naval Air Station Joint Reserve Base \\ NAVD 88 North American Vertical Datum of 1988 \\ Navy U.S. Navy \\ NAWC (former) Naval Air Warfare Center \\ NBCMA Northampton Bucks County Municipal Authority \\ NGVD 29 National Geodetic Vertical Datum of 1929 \\ OTV optical televiewer \\ PFAS Per- and polyfluoroalkyl substances \\ PFOA Perfluorooctanoic acid \\ PFOS Perfluorooctanesulfonic acid \\ PHA provisional health advisory \\ UCMR3 Third Unregulated Contaminant Monitoring Rule \\ USGS U.S. Geological Survey \\ VOC volatile organic compounds \\ WMA Warminster Municipal Authority \\ WTWSA Warwick Township and Sewer Authority
}




\title{
Geophysical and Video Logs of Selected Wells at and near the Former Naval Air Warfare Center Warminster, Bucks County, Pennsylvania, 2017-19
}

\author{
By Lisa A. Senior, J. Alton Anderson, and Philip H. Bird
}

\section{Abstract}

The U.S. Geological Survey (USGS) collected borehole geophysical and video logs in 17 open-hole wells in Northampton, Warminster, and Warwick Townships, Bucks County, Pennsylvania during 2017-19 to support detailed groundwater investigations at and near the former Naval Air Warfare Center (NAWC) Warminster, where groundwater contamination with per- and polyfluoroalkyl substances (PFAS) had become a concern since 2014. The area is underlain by the Triassic Stockton Formation, which forms a fracturedsedimentary-rock aquifer used for private, industrial, and public drinking-water supply. The geophysical and video logs were used to characterize the boreholes and identify potential water-bearing fractures for subsequent detailed investigations. Of the 17 wells that were logged, subsequent investigations were conducted by USGS in 15 wells and included hydraulic tests of discrete water-bearing zones using a straddle-packer system in 13 wells and depth-discrete point sampling in 2 wells. These 15 wells ranged in depth from about 210 to 604 feet (ft) below land surface (bls) and included six new 6-inch diameter wells drilled to initial depths of $600 \mathrm{ft}$ bls on the former NAWC Warminster base property in 2018 and nine 8to 12-inch diameter existing former production or unused test wells. Partial geophysical or video logs also were collected by USGS during 2018 in two other wells that were not included in subsequent detailed investigations.

Most wells had numerous water-bearing fractures or openings throughout the depth of the open boreholes. Most of these water-bearing features appeared to be openings parallel to bedding or high-angle fractures approximately orthogonal to bedding. Casing lengths ranged from about 19 to $93 \mathrm{ft}$ bls. Depth to the ambient water level at the time of logging ranged from about $1.8 \mathrm{ft}$ above land surface in a flowing well to about $55 \mathrm{ft}$ bls. Measured borehole flow was predominantly downward in most of the deepest wells (greater than $400 \mathrm{ft}$ ), which were commonly located at the highest land-surface elevations, and contained inflow from fractures at relatively shallow depths and outflow through fractures near or below depths of $500 \mathrm{ft}$ bls. Borehole flow was predominantly upward in most wells less than $400 \mathrm{ft}$ in depth.

\section{Introduction}

Groundwater is a substantial source of public, domestic, and industrial water supply in areas underlain by the Stockton Formation, a fractured sandstone aquifer, in southern Montgomery and Bucks Counties, Pennsylvania, where two formerly active military bases are located. Both bases were active for at least 50 years from the 1940s until they were closed at the recommendation of the Base Realignment and Closure commission. The Naval Air Warfare Center (NAWC) Warminster (formerly the Naval Air Development Center, Johnsville) in Warminster and Northampton Townships, Bucks County (fig. 1) was active during 1944-96. Since 1996, all but about 4 acres of the former NAWC Warminster 824-acre property has been transferred from the U.S. Navy (Navy) to local municipalities, Bucks County, or private owners. About 3 miles (mi) west of NAWC Warminster, the former Naval Air Station Joint Reserve Base (NASJRB) Willow Grove in Horsham Township, Montgomery County, Pennsylvania was operated by the Navy from 1942 until September 2011, with a portion currently (2020) operated by the Pennsylvania Air National Guard (ANG) and designated Horsham Air Guard Station (HAGS) (fig. 1).

Previous investigations identified areas of groundwater contaminated by volatile organic compounds (VOCs) at both NAWC Warminster and NASJRB Willow Grove, which subsequently were addressed by remediation (Battelle, 2016). Ongoing remediation for VOCs at present (2020) includes bioremediation at NASJRB Willow Grove (Naval Facilities Engineering Command, 2018) and pump-and-treat technology at NAWC Warminster (Battelle, 2016).

In summer 2014, through sampling of production wells under the third Unregulated Contaminant Monitoring Rule (UCMR3; U.S. Environmental Protection Agency, 2012), groundwater at and near the former NAWC Warminster and former NASJRB Willow Grove was found to be contaminated with perfluorooctanesulfonic acid (PFOS) and perfluorooctanoic acid (PFOA), compounds that may pose a risk to human health if present above certain concentrations in drinking water. In 2014, the U.S. Environmental Protection Agency (EPA) provisional health advisory (PHA) levels were 0.2 


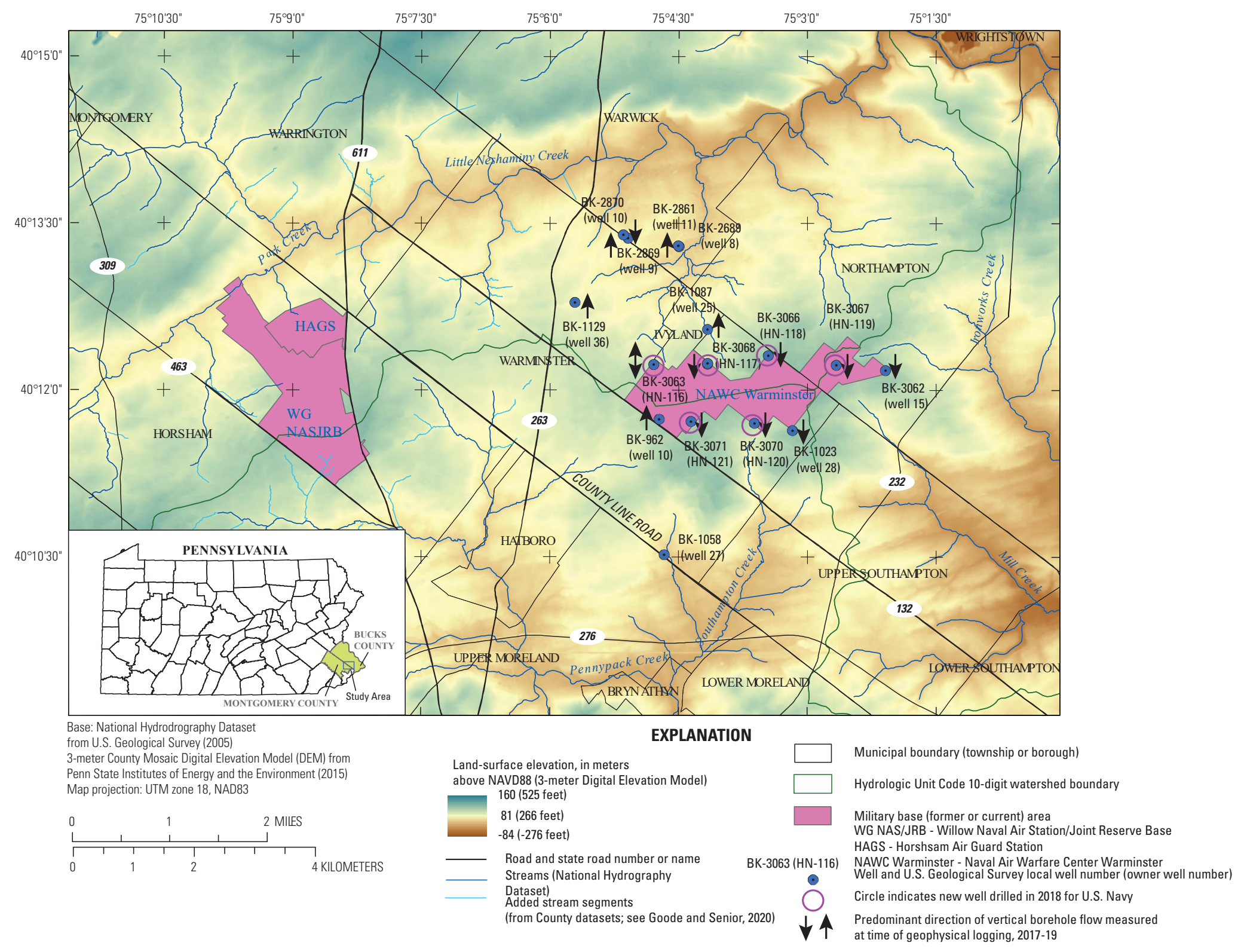

Figure 1. Location of former Naval Air Warfare Center (NAWC) Warminster, former Naval Air Station Joint Reserve Base (NASJRB) Willow Grove, and active Horsham Air Guard Station (HAGS), land-surface elevations, streams, and location of wells with geophysical and video logs collected by U.S. Geological Survey near NAWC Warminster during 2017-19, Bucks and Montgomery Counties, Pennsylvania. 
micrograms per liter $(\mu \mathrm{g} / \mathrm{L})$ for PFOS and $0.4 \mathrm{ug} / \mathrm{L}$ for PFOA in drinking water (U.S. Environmental Protection Agency, 2014). PFOS and PFOA are part of a group of compounds more broadly designated per- and polyfluoroalkyl substances (PFAS). Five production wells in Horsham and Warrington Townships were shut down in 2014 after UCMR3 sampling showed that produced water had some PFAS concentrations that exceeded the PHA levels. In May 2016, the EPA revised the PFOS and PFOA health advisories to lower concentration levels and established a Lifetime Health Advisory (LHA) not to exceed 70 nanograms per liter $(\mathrm{ng} / \mathrm{L})$ or 70 parts per trillion (ppt; equivalent to $0.07 \mu \mathrm{g} / \mathrm{L}$ ) for combined concentrations of PFOS and PFOA (U.S. Environmental Protection Agency, 2016). Groundwater from production or private domestic wells was still a primary source of water in the area in 2014, but after May 2016, additional (at least 13) production wells were shut down in Horsham, Warrington, and Warminster Townships because of health concerns related to the presence of PFOS and PFOA in concentrations above health advisory levels. Since 2016, some supply wells have remained active, or resumed active status, with treatment that was subsequently installed to remove PFOS and PFOA from pumped groundwater, as needed.

When PFOS and PFOA were identified in samples from production wells in 2014, production wells on and near the former NAWC Warminster and NASJRB Willow Grove were the primary source of public water supply for communities within and surrounding these facilities and private domestic wells supplied many nearby residences. Potential sources of PFOS and PFOA in the area include fire-suppressant compounds (fluorinated surfactants in aqueous film forming foams used on and (or) near these facilities when the bases were operating (TetraTech, 2014; Resolution Consultants, 2019).

After PFAS were discovered in the area surrounding the bases, the Navy and the ANG offered nearby residences with private domestic wells that yielded water with PFOS and PFOA concentrations greater than the LHA to be connected to public drinking water supplies. The Navy and ANG also have established a program to monitor PFOS and PFOA concentrations in water from nearby residential wells that have not been connected to public supply; these monitored wells include those for which combined PFOS plus PFOA concentrations were less than the LHA of $0.07 \mu \mathrm{g} / \mathrm{L}$ but higher than $0.04 \mu \mathrm{g} / \mathrm{L}$ (U.S. Navy, 2016; Battelle, 2017).

Management and mitigation of groundwater that is contaminated with PFOS and PFOA on and near the former NAWC Warminster and the nearby NASJRB Willow Grove requires assessment of the sources and distribution of contaminant occurrence. In 2014, the Navy and its contractors began sampling soils, streams, and groundwater through preliminary remedial investigations. The Navy also requested technical support from the USGS in conducting geophysical logging and aquifer-interval testing of wells as part of investigations to characterize PFAS distribution in groundwater.

\section{Previous Investigations}

Prior to 2014, in studies related to remedial investigations by the Navy and their contractors at or near the former NAWC Warminster base, the U.S. Geological Survey (USGS) collected geophysical logs (Conger, 1998; Conger and Bird, 1999; Sloto, 2008), collected geophysical logs and conducted aquifer-interval-isolation (packer) testing of wells (Sloto, 1997, 1998), conducted hydrologic investigations (Sloto and others, 1998), and prepared a water-table map (Sloto and Grazul, 1995a). Sloto and others (1995b) and Sloto (2010) investigated groundwater flow and VOC contaminant migration at a Superfund site near NAWC Warminster. The USGS also conducted townshipwide hydrogeologic studies for Warminster Township (Sloto and Davis, 1982) and Warwick Township (Bird, 1998) and prepared a water-table map for Warwick Township (Rowland, 1997). Sloto and others (1996) described the hydrology of the Stockton Formation in Hatboro Borough and Warminster Township.

Since 2014 when PFAS was detected in groundwater at or near the former bases, remedial investigations by the Navy, ANG, and their contractors have been conducted to describe PFAS concentrations in soils, groundwater, and streams at and near the former NASJRB Willow Grove, active Horsham Air Guard, and former NAWC Warminster (Battelle, 2016; Leidos, 2018; Resolution Consultants, 2019). The USGS also developed a preliminary regional groundwater flow model that simulated path lines from possible PFAS source areas at the Warminster and Willow Grove bases (Goode and Senior, 2020).

Additional investigations have been conducted by local water suppliers, by regulatory agencies, and by parties responsible for contamination of groundwater in the area. Many of these investigations are described in documents available in public record depositories. Specific investigations that provided data for this study are cited throughout this report.

\section{Purpose and Scope}

This report documents the complete geophysical and video log data collected by the USGS in 15 wells identified for further investigation from December 2017 through October 2019, including 6 new wells drilled by the Navy in 2018 and 9 existing wells on or near the former NAWC Warminster base. Partial geophysical or video logs were also collected in two other wells by the USGS during 2018. The geophysical data documented in this report include a summary of the type of logs collected at each of the 15 boreholes under ambient and (or) pumping conditions; and for each well, directions of vertical borehole flow under ambient and (or) pumping conditions and identification of probable or possible water-bearing fractures. Possible water-bearing fractures, as determined from partial logs, for the two other wells also are briefly described. The geophysical and video log data for the 15 boreholes were collected and interpreted to support 
selection of discrete intervals in 13 boreholes to be tested using either straddle packers for assessing hydraulic properties and PFAS concentrations in water from those intervals or, in two wells, selection of depths for collection of water samples at discrete points for PFAS concentrations.

\section{Hydrogeologic Setting}

The study area lies within the Piedmont physiographic province, with most of the study area in the GettysburgNewark Lowlands Section, bounded on the south by Piedmont Upland and Lowland Sections (fig. 2), and characterized by rolling topography and shallow valleys (Sevon, 2000). The Gettysburg-Newark Lowlands are underlain by sedimentary rocks of the Newark Basin, which were deposited in a rift basin during the Triassic (about 252 to 201 million years ago) and subsequently buried, compacted, and faulted, and in places, intruded by diabase (Lyttle and Epstein, 1987). Sedimentary formations in the Newark Basin, in order of decreasing age, are the Stockton Formation, Lockatong Formation, and Brunswick Group. The Piedmont Upland and Lowland Sections are underlain by Paleozoic metasedimentary rocks and older (Proterozoic) metamorphic rocks.

The central part of the study area is underlain by the Triassic Stockton Formation (fig. 3), which consists of gray to reddish brown sandstones and conglomerates, with siltstone and shale. The Stockton Formation was deposited unconformably on folded and faulted metamorphic rocks of probable lower Paleozoic and Proterozoic age (Berg and others, 1980; Lyttle and Epstein, 1987), which crop out along the southern border of the Stockton Formation and include carbonates, quartzites, schists, and gneisses (fig. 3). The Stockton Formation has been divided into three members in Montgomery County that are present in a generally finingupward sequence: a lower arkose member with the coarsest deposits (conglomerates and sandstones), a middle arkose member consisting of fine- to medium-grained sandstones, and the upper shale member containing the finest deposits (shales, siltstones, and fine-grained sandstones) (Rima and others, 1962). Locally, lithologies may interfinger in the Stockton Formation and beds may pinch out (Rima and others, 1962) or be laterally discontinuous, likely a result of the fluvial or deltaic origin of some deposits within the Stockton Formation (Turner-Peterson and Smoot, 1985).

The Lockatong Formation, which overlies and is conformable with the Stockton Formation, consists of fine-grained lacustrine deposits (siltstones and shales) and is relatively resistant to erosion, forming ridges that rise above flat or rolling topography underlain by the Stockton Formation to the south and rocks of the Brunswick Group (shales, siltstones, and fine-grained sandstones) to the north. (fig. 3). The Brunswick Group overlies the Lockatong Formation.

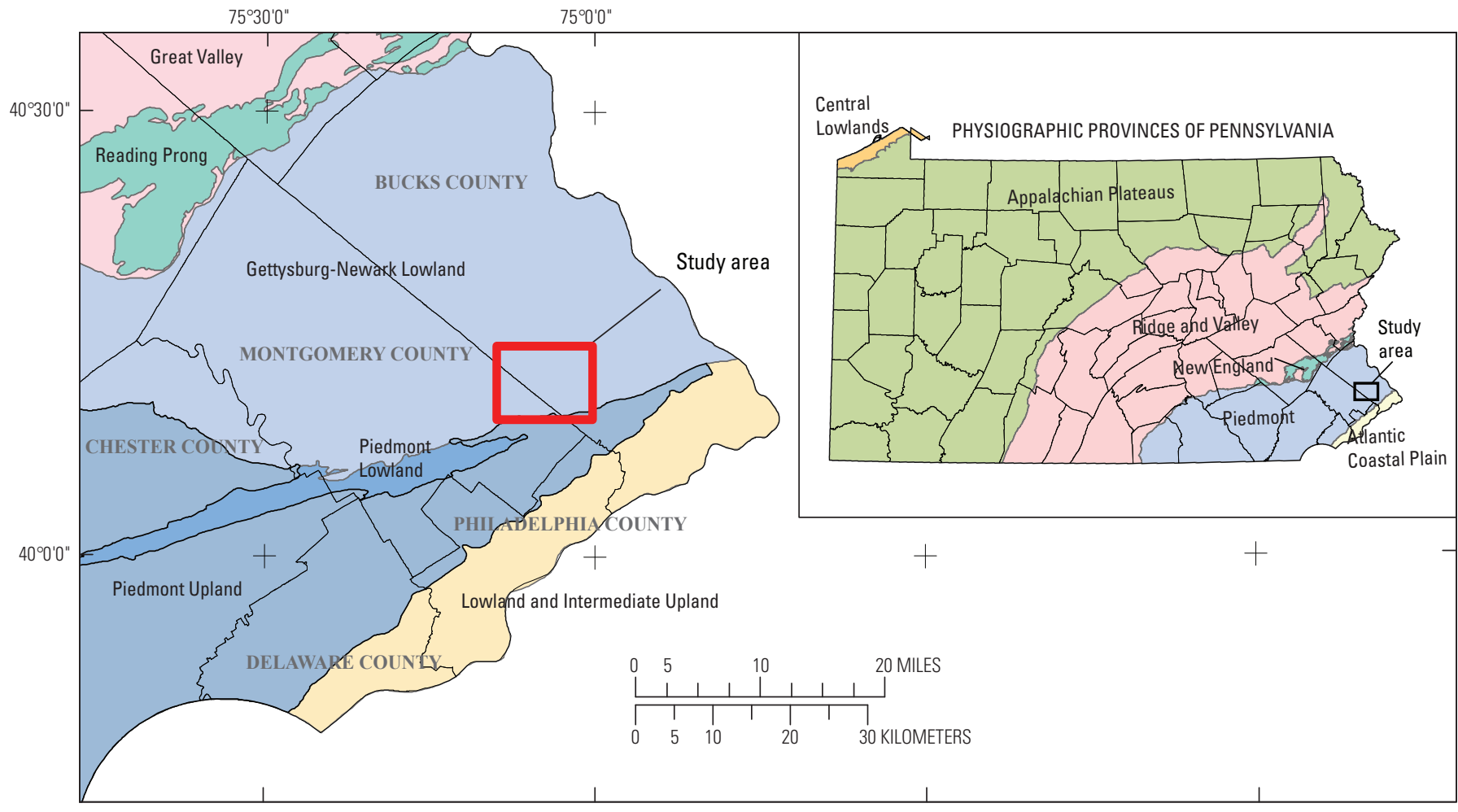

From Sevon (2000); Pennsylvania Bureau of Topographic and Geologic Survey (2008a, b)

Figure 2. Physiographic provinces of Pennsylvania (inset) and sections in study area in southeastern Pennsylvania. 


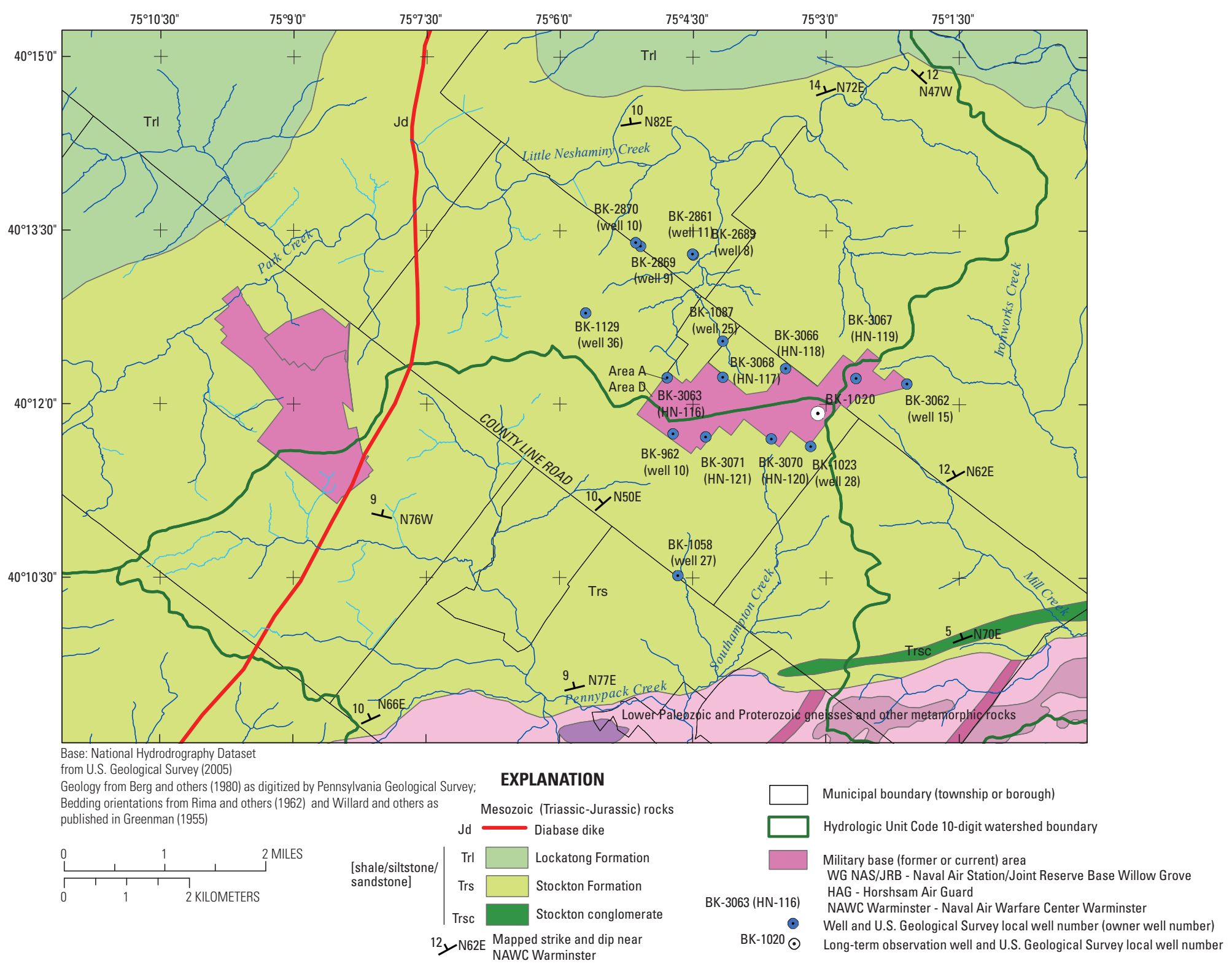

Figure 3. Mapped geology, including bedrock geologic units, that underlie the study area and bedding orientations in the Stockton Formation, as well as streams, location of wells with geophysical and video logs collected by U.S. Geological Survey near former Naval Air Warfare Center Warminster during 2017-19, and selected U.S. Geological Survey observation wells, Bucks and Montgomery Counties, Pennsylvania. Geology from Berg and others (1980); bedding orientations from Rima and others (1962) and Willard and others and published in Greenman (1955). 
Bedding within the Stockton Formation in southeastern Montgomery and Bucks Counties generally strikes northeast or east-northeast and tilts to the northwest, dipping about 5 to 18 degrees to the northwest or north-northwest in this region, with an average dip of about 12 degrees (Rima and others, 1962). Although bedding in the Stockton Formation may be laterally discontinuous in places owing to interbedding of lithologies, the beds have been mapped as oriented with the overall general northwest-dipping structure. Close to NAWC Warminster, the mapped strike of bedding in the Stockton Formation is about N. $50^{\circ}$ E. to N. $62^{\circ}$ E., and ranges from about N. $66^{\circ}$ E. to N. $77^{\circ}$ E. south of NAWC Warminster close to the contact with older Paleozoic rocks and from about $\mathrm{N}$. $72^{\circ}$ E. to N. $82^{\circ}$ E. north of NAWC Warminster near Little Neshaminy Creek (fig. 3). Northwest trending strikes have been mapped in a few locations in the area, suggesting possible displacement by faults. Other similar bedding orientations of the Stockton Formation near the former NAWC Warminster are reported as having an approximate strike of N. $65^{\circ} \mathrm{E}$. and dip of $9^{\circ} \mathrm{NW}$. (Sloto and others, 1995b) and strike of N. $71^{\circ}$ E. and dip of $5-8^{\circ} \mathrm{NW}$. (Sloto and others, 1998). Generally, other Triassic sedimentary rocks in the study area, in addition to the Stockton Formation, also strike northeast and dip northwest, except where interrupted by faulting (Schlische, 1992). Both major and minor faults are present in the area. A major regional fault (Chalfont Fault) is about $3 \mathrm{mi}$ (5 kilometers $[\mathrm{km}]$ ) north of NAWC Warminster and NASJRB Willow Grove, and a zone of intense normal faulting south of the Chalfont Fault has been mapped about $1 \mathrm{mi}(1.5 \mathrm{~km})$ west of the NASJRB Willow Grove (Schlische, 1992). A north-south trending, steeply dipping diabase dike is mapped (fig. 3) as intruding the Stockton Formation on the eastern border of the former NASJRB Willow Grove (Rima and others, 1962; Lyttle and Epstein, 1987). Other smaller dikes may be present, as indicated in mapping by Lyttle and Epstein (1987) that shows a minor dike about $1 \mathrm{mi}$ or less west of the north-south trending dike on the eastern border of NASJRB Willow Grove.

Depth to competent bedrock generally is about 40 feet (ft) or less but varies depending on lithology and topographic setting (Low and others, 2002). The competent bedrock is overlain by weathered bedrock (saprolite) and soil formed in situ and, in a few places in the southern part of the study area, by thin deposits of Tertiary and Cretaceous age unconsolidated sediments.

The Triassic sedimentary geologic units that underlie the study area form fractured-rock aquifers. Recharge to the fractured-rock aquifers occurs through the overlying soil and weathered rock, and groundwater flows through a network of fractures both parallel and orthogonal to bedding, commonly resulting in apparent preferential flow and permeability in the strike direction (parallel to bedding). Lateral and vertical changes in lithology in the Stockton Formation affect aquifer water-bearing properties, as finer-grained deposits (shales, siltstones) commonly have lower permeability than coarsergrained deposits (sandstones and conglomerates) in the formation (Rima and others, 1962). The hydrogeology of the
Stockton Formation and other geologic units of the study area has been described in more detail by Greenman (1955), Rima and others (1962), Longwill and Wood (1965), and Newport (1971). Low and others (2002) provide an overview of geohydrologic properties of the Stockton and other formations from well records and previous investigations in southeastern Pennsylvania.

Although precipitation commonly is distributed relatively evenly throughout the year, groundwater recharge varies seasonally, with the lowest recharge rates occurring when evapotranspiration rates are highest in late summer to fall, and the highest recharge rates occurring in winter to spring, as reflected in annual fluctuations in water levels. For example, in the USGS observation well BK-1020, located in the study area on NAWC Warminster (fig. 3), long-term (1975-2019) daily mean depth to water is greatest in the fall months and least in spring months (Goode and Senior, 2020), reflecting relatively lower and higher seasonal net recharge rates, respectively. Groundwater discharges locally to streams or to pumping wells. Streams draining the area near NAWC Warminster include Little Neshaminy Creek, Neshaminy Creek, Pennypack Creek, and their tributaries (figs. 1 and 3). Both the former Warminster and Willow Grove bases lie on high ground (fig. 1), which forms topographic divides between stream basins.

\section{Methods}

Geophysical and video logs were collected using the methods described below from boreholes at or near former NAWC Warminster from November 2017 through October 2019.

\section{Geophysical Logs}

Geophysical logs were collected by the USGS using a truck-mounted drawworks that holds approximately $2,000 \mathrm{ft}$ of armored four-conductor cable. Each downhole tool (probe) is attached to the cable head and run down the well at the prescribed speed. Most tools collect data on multiple characteristics; for example, the fluid-conductivity probe collects fluid conductivity, temperature, and gamma logs simultaneously. Data-collection speeds (rates of descent or ascent) range from 20 feet per minute ( $\mathrm{ft} / \mathrm{min}$ ) for most logging tools to about $5 \mathrm{ft} /$ min for the optical and acoustic logging tools. Data from each tool are continually recorded on a laptop computer and are viewed in real time in the field.

The types of geophysical logs collected from the boreholes include caliper, natural gamma, electromagneticinduction, electrical resistance, borehole-image, deviation, fluid-property (temperature and conductivity), and flowmeter logs (table 1). In addition, borehole video logs were collected in the boreholes. The caliper logs were collected by mechanical and acoustic methods. Borehole-image logs were collected 
Table 1. Description of geophysical logs, reporting units, and abbreviations for logs collected by U.S. Geological Survey at and near Naval Air Warfare Center Warminster, Bucks County, Pennsylvania, 2017-19.

[EM, electromagnetic; N, normal; --, no data or none]

\begin{tabular}{|c|c|c|c|}
\hline Type of log & $\begin{array}{l}\text { Abbreviation for } \\
\log \end{array}$ & Units & Abbreviation for units \\
\hline Depth & Depth & Feet below land surface & $\mathrm{ft}$ bls \\
\hline Caliper & Caliper & Inches & in \\
\hline Acoustic caliper & Acou Cal & Inches & in \\
\hline Natural gamma & Gamma & Counts per second & cps \\
\hline Medium EM-induction conductivity & M Ind Cond & MilliSiemens per meter & $\mathrm{mS} / \mathrm{m}$ \\
\hline Deep EM-induction conductivity & D Ind Cond & MilliSiemens per meter & $\mathrm{mS} / \mathrm{m}$ \\
\hline Medium EM-induction resistivity & M Ind Res & Ohm-meter & Ohm-m \\
\hline Deep EM-induction resistivity & D Ind Res & Ohm-meter & Ohm-m \\
\hline Single-channel EM-induction conductivity & COND & MilliSiemens per meter & $\mathrm{mS} / \mathrm{m}$ \\
\hline Single-channel EM-induction resistivity & RES & Ohm-meter & Ohm-m \\
\hline Short normal $(16 \mathrm{~N})$ resistivity & $\operatorname{RES}(16 \mathrm{~N})$ & Ohm-meter & Ohm-m \\
\hline Long normal $(64 \mathrm{~N})$ resistivity & $\operatorname{RES}(64 \mathrm{~N})$ & Ohm-meter & Ohm-m \\
\hline Single-point resistance & RES(SP) & Ohms & Ohm \\
\hline Tilt (from acoustic televiewer log) & Tilt ATV & Degrees from vertical & $\operatorname{deg}$ \\
\hline Azimuth & Azi & Degrees from magnetic north & MN \\
\hline Acoustic televiewer & ATV & Image displayed relative to magnetic north & -- \\
\hline Optical televiewer & OTV & Image displayed relative to magnetic north & -- \\
\hline Fracture orientation & Frac Or & Degrees from magnetic north & MN \\
\hline Fluid temperature, ambient & TEMP amb & Degrees Fahrenheit & $\operatorname{deg} F$ \\
\hline Fluid conductivity, ambient & Fl Cond amb & MicroSiemens per centimeter & $\mu \mathrm{S} / \mathrm{cm}$ \\
\hline Fluid resistivity, ambient & RES (FL) amb & Ohm-meter & Ohm-m \\
\hline EM flowmeter, ambient & $\begin{array}{l}\text { EMFM amb or } \\
\text { Flow amb }\end{array}$ & Gallons per minute & $\mathrm{gal} / \mathrm{min}$ \\
\hline Heat-pulse flowmeter, ambient & HPFM amb & Gallons per minute & $\mathrm{gal} / \mathrm{min}$ \\
\hline Fluid temperature, pumping & TEMP pmp & Degrees Fahrenheit & $\operatorname{deg} F$ \\
\hline Fluid conductivity, pumping & Fl Cond pmp & MicroSiemens per centimeter & $\mu \mathrm{S} / \mathrm{cm}$ \\
\hline Fluid resistivity, pumping & RES(FL) pmp & Ohm-meter & Ohm-m \\
\hline EM flowmeter, pumping & $\begin{array}{l}\text { EMFM pmp or } \\
\text { Flow pmp }\end{array}$ & Gallons per minute & $\mathrm{gal} / \mathrm{min}$ \\
\hline Heat-pulse flowmeter, pumping & HPFM pmp & Gallons per minute & $\mathrm{gal} / \mathrm{min}$ \\
\hline
\end{tabular}

with an optical televiewer (OTV) and an acoustic televiewer (ATV). Borehole-deviation logs were collected with threeaxis fluxgate magnetometers and vertical inclinometers that are incorporated into the ATV and OTV probes. Flowmeter logs were collected by heat-pulse or electromagnetic methods. Fluid and flowmeter logs commonly were collected under both ambient and pumping conditions to help identify water-bearing fractures. For measurements of flow and fluid logs under pumping conditions, water in the well commonly was pumped at a constant rate of about 2 gallons per minute ( $\mathrm{gal} / \mathrm{min}$ ) using a pump placed a few feet below the ambient water level in the well. Applications of geophysical logs in groundwater studies are described by Keys (1990) and Williams and Lane (1998). The geophysical logs used in this investigation are described briefly below. Technical descriptions of logs are from Keys (1990), Anderson and others (2009), and Reynolds and others (2015).

Mechanical and acoustic caliper logs record the diameter of the borehole. Changes in borehole diameter are related to drilling and construction procedures; lithologic contacts and competency of lithologic units; and the presence of various openings including fractures, faults, bedding-plane partings, joints, and solution features. Mechanical-caliper logs were collected with a spring-loaded, three-arm averaging tool; 
acoustic-caliper logs were calculated from acoustic travel times collected with the ATV tool. Caliper logs were used in the delineation of fractures, solution features, and lithology, and to confirm well and casing depths and diameters.

Gamma logs measure the natural gamma radiation of the rock units penetrated by the borehole. Major gamma emitters are uranium, thorium, and daughter products of potassium- 40 . Sedimentary rocks with relatively high gamma radiation when compared to other lithologic units commonly include shales, mudstones, and other argillaceous units. Igneous and metamorphic rocks rich in potassium feldspar typically are also high gamma emitters. The gamma tool has a vertical resolution of 1 to $2 \mathrm{ft}$. Gamma logs collected in open holes and through steel casing may be used for lithologic identification and stratigraphic correlation.

Electromagnetic-induction conductivity and resistivity logs measure the electrical conductivity of bedrock and water surrounding the borehole. In this study, the logs were collected at a frequency of 40 kilohertz. The electromagnetic (EM)-induction tool has a vertical resolution of about $2 \mathrm{ft}$ and primarily samples volumes to about 18 inches (in.) radially from the well. It generally is not affected by the electrical properties of the wellbore fluid for diameters less than $8 \mathrm{in}$. The volume of investigation of an induction probe is a function of coil spacing, with larger spacings measuring larger distances from the borehole. The EM-induction logs were collected using either a dual coil configuration (medium and deep depths of investigation) or single coil configuration (medium depth of investigation). Electrical conductivity measurements are affected by the argillaceous content and porosity of the rocks and by the concentration of dissolved solids in the pore fluid. Electromagnetic-induction conductivity logs are most effective in formations with high electrical conductivities (low resistivities), such as shales and mudstones. The inverse of EM-induction conductivity is EM-induction resistivity. The EM-induction resistivity logs generally are similar to normalresistivity and single-point resistance logs in wells with fresh water and can be used as indicators of lithology. Resistivity is greater for sandstones than for shales under these conditions.

Normal-resistivity logs measure the electrical resistivity of the rocks and water surrounding the borehole. Electrical resistivity measurements made using variously spaced electrodes commonly consist of short-normal (16 in. spacing between electrodes) and long-normal (64 in. spacing between electrodes) resistivities, or near and far resistivities, respectively, that have two different volumes of investigation. Electrical resistivity measurements are similarly affected by the argillaceous content and porosity of the rocks and by the dissolved-solids concentration of the pore fluid (Archie, 1942). However, unlike the EM-induction logs, normalresistivity logs are most effective in formations having high electrical resistivities (low conductivities). A lower resistivity corresponds to higher porosity and (or) smaller grain size because the surface area associated with fine particles promotes the transmission of electric current (Biella and others, 1983; Kwader, 1985). Due to the smaller area of investigation sampled by the near measurement, short-normal logs are more affected by the borehole fluid than are the far measurements. Correspondingly, the long-normal logs have a greater volume of investigation beyond the borehole and are proportionally less influenced by the borehole fluid than is the near measurement; however, their vertical resolution is less than that of the short-normal logs.

Single-point resistance logs measure the resistance, in ohms, between an electrode in the well and an electrode at the land surface. Single point logs are useful qualitative indicators of lithology. However, single-point-resistance logs are more affected by the borehole fluid than induction and normalresistivity logs and cannot be related quantitatively to porosity or to the salinity of water in those pore spaces because no provision exists for determining the length or cross-sectional area of the travel path of the current between electrodes.

Acoustic televiewer (ATV) logs record a 360-degree magnetically oriented acoustic image of the borehole wall (Williams and Johnson, 2004). ATV logs can be collected in clear or turbid water. The ATV provides high-resolution information on the location and orientation (strike and dip) of fractures or bedding within a borehole, such that structural features with widths greater than $0.02 \mathrm{ft}$ can be identified. ATV logs are presented relative to magnetic north. For this study, ATV logs were used to identify locations of fractures and bedding-plane openings and to determine orientation of selected features identified as hydraulically active waterbearing openings based on interpretation of other geophysical logs. The orientations of the selected water-bearing fractures as determined from analysis of the ATV and (or) optical televiewer (OTV) logs are presented in tadpole plots of the fracture azimuth and dip amplitude oriented to magnetic north.

Optical televiewer (OTV) logs record a 360-degree oriented optical image of the wellbore wall. OTV logs can be collected above the water level and below the water level where the water is clear. Features with widths greater than $0.008 \mathrm{ft}$ can be identified. OTV logs can be used to characterize bedding, lithology, fractures, and solution features (Williams and Johnson, 2004). OTV logs are presented relative to magnetic north. For this study, the OTV logs were used to help identify locations of fractures and bedding-plane openings and to determine the orientation of selected features identified as hydraulically active water-bearing openings based on interpretation of other geophysical logs and in conjunction with ATV logs.

Deviation logs measure the inclination and direction of (deviation of) the well from vertical. Inclination generally is measured within \pm 0.5 degree and direction within \pm 2 degrees. Deviation direction is recorded relative to magnetic north. Borehole deviation plots can be corrected to account for magnetic declination and show geographic (true) north at 0 degrees. In wells that penetrate magnetite bearing zones, deviation direction can be affected by the secondary magnetic field generated by the ferrous minerals. Although magnetite has been identified as part of accessory heavy mineral suites in the Stockton Formation as described by D.B. McLauglin 
(Willard, 1959) and is associated with some diabase intrusion in the Newark Basin (Robinson, 1988), the magnitude of the possible effect on the deviation logs for this study is estimated to be small.

Fluid-temperature logs record the temperature of air and water in the wellbore. Temperature gradients that deviate from the geothermal gradient may indicate intervals of vertical flow within the borehole. Temperature logs were used to delineate possible changes in wellbore flow related to inflow or outflow and, thus, to help identify possible water-bearing fractures in the borehole.

Fluid-resistivity and conductivity logs record the electrical resistivity of water in the borehole. Fluid electrical resistivity is inversely related to the concentration of dissolved solids in borehole water. Fluid-conductivity logs are the inverse of fluid-resistivity logs. Fluid conductance is directly related to the concentration of dissolved solids in borehole water. Inflections or changes in the slope of fluid-resistivity (or fluid-conductivity) logs may indicate zones of inflow to, or outflow from, the borehole. Fluid-conductivity logs were used, in conjunction with fluid temperature logs, to delineate possible changes in wellbore flow and to identify possible water-bearing fractures in the borehole.

Flow logs record the direction and rate of vertical flow in the borehole. Vertical flow occurs in wells that penetrate two or more water-producing fracture zones with different hydraulic heads (water levels). Flow in the borehole is from zones of higher head to zones of lower head. An electromagnetic (EM) flowmeter with a flexible rubber diverter fitted to the borehole diameter (6 or 8 in.) and a measurement range of 0.05 to 15 $\mathrm{gal} / \mathrm{min}$ was used to measure flow in most boreholes. The EM flowmeter (Young and Pearson, 1995) measures fluid velocity, based on Faraday's Law, which states that the flow of an electrically conductive fluid through an induced magnetic field generates a voltage gradient that is proportional to its velocity. In four boreholes, a heat-pulse flowmeter with a flexible rubber diverter and a measurement range of 0.01 to $1.5 \mathrm{gal} /$ min was used to measure flow in a stationary mode at various depths. The heat-pulse flow meter (Hess, 1982) measures the travel time of a thermal pulse between a set of upper and lower heat sensors (thermistors).

For the six boreholes greater than 8 in. in diameter, an 8 -in. diverter (largest available with the equipment) was used in this investigation. Flow measured with the 8 -in. diverter is less than actual flow in wells with diameters greater than 8 in. in diameter and may be considered semi-quantitative because some flow bypasses the diverter. Reported flow values generally reflect corrected field measurements to account for apparent differences between raw measurements and known flow values. The corrections were based on zero flow in casing under ambient conditions and known flow (as measured for discharge from an active pump in well) in casing under pumping conditions, when possible.

Flow logs and fluid-property (temperature and resistivity) logs were collected (when possible) under (1) steady-ambient (amb) conditions and (2) steady-pumping ( $\mathrm{pmp}$ ) conditions to provide a contrast of flow-rate gain or loss at discrete fracture zones, and thus can assist in identifying the presence and relative productivity of water-bearing fractures (Paillet, 2000, 2001). Pumping rates ranged from about 1 to $5 \mathrm{gal} / \mathrm{min}$, but most commonly were about $2 \mathrm{gal} / \mathrm{min}$, during collection of flow and fluid logs in wells logged for this study. Flow logs were primarily used to identify the presence of water-bearing features and were not analyzed to quantitatively determine transmissivity of water-bearing zones using methods described by Paillet (2000), partly because of the uncertainty associated with flow measurements in the large-diameter wells.

\section{Video Logs}

Borehole video logs record images of the borehole with a camera lens most commonly oriented as looking down the borehole. The depth of the borehole video log corresponds to the upper edge of the field of view. The video log is useful for describing the characteristics of the borehole construction, water visibility, lithology, fracture extent and general orientation for fractured-rock aquifers, and the presence of other features such as turbulence or cascading water. Field notes made during video logging summarize principal observations. Fractures described as horizontal are low-angle openings that may be parallel to bedding planes in the shallowly dipping sedimentary formations such as the Stockton Formation. Fractures described as vertical are high-angle openings that may be orthogonal to bedding or related to faulting.

\section{Geophysical and Video Logs}

Geophysical and video logs were collected during 2017-19 from 17 boreholes (figs. 1 and 3), including 15 wells identified for further investigation and 2 other wells (BK-1058 and BK-3069) (table 2 and 3). The most complete suite of geophysical and video logs (table 3 ) were collected in the 15 wells identified for subsequent investigation and which ranged from 201.5 to $604 \mathrm{ft}$ in depth and 6 to $12 \mathrm{in}$. in diameter (table 2). Of the 15 boreholes, 9 were existing boreholes drilled as test wells or formerly active production wells originally drilled for the Northampton Bucks County Municipal Authority (NBCMA), Warminster Municipal Authority (WMA), or Warwick Township Water and Sewer Authority (WTWSA), and 6 were new 6 -in. diameter boreholes drilled by the Navy during 2018 (fig. 1). Only a partial suite of geophysical logs and a video $\log$ were collected in the 485 -ft-deep unused production well BK-1058 (well 27), and only a partial video log was collected in a new shallow observation well BK-3069 (HN-120S) (table 2 and 3).

Fluid and flow logs were collected under ambient and pumping conditions in most (12 of 15) wells to help identify water-bearing fractures. Ambient water levels were recorded at the time of logging and, if wells were pumped during geophysical logging, pumping rate and drawdown at end of 
Table 2. Characteristics of wells with geophysical and video logs collected by U.S. Geological Survey at and near the former Naval Air Warfare Center (NAWC) Warminster, Bucks County, Pennsylvania, 2017-19.

[WMA, Warminster Municipal Authority; WTWSA, Warwick Township Water and Sewer Authority; NBCMA, Northampton Bucks County Municipal Authority; dd mm ss, degrees minutes seconds; ft bls, feet below land surface; gal/min, gallons per minute; ft, foot; in., inch; <, less than; --, no data]

\begin{tabular}{|c|c|c|c|c|c|c|c|c|c|c|c|c|c|}
\hline $\begin{array}{l}\text { USGS } \\
\text { local } \\
\text { well } \\
\text { name }\end{array}$ & Owner & $\begin{array}{c}\text { Owner } \\
\text { well name }\end{array}$ & $\begin{array}{l}\text { Latitude }^{1} \\
\text { (dd mm ss) }\end{array}$ & $\begin{array}{l}\text { Longitude } 1 \\
\text { (dd mm ss) }\end{array}$ & $\begin{array}{l}\text { Casing } \\
\text { length } \\
\text { (ft bls) }\end{array}$ & $\begin{array}{l}\text { Logged } \\
\text { depth } \\
\text { (ft bls) }\end{array}$ & $\begin{array}{c}\text { Hole } \\
\text { diameter } \\
\text { (in.) }\end{array}$ & $\begin{array}{c}\text { Date(s) of } \\
\text { geophysical } \\
\text { logs }\end{array}$ & $\begin{array}{c}\text { Ambient } \\
\text { depth to } \\
\text { water at } \\
\text { time of } \\
\text { logging } \\
\text { (ft bls) }\end{array}$ & $\begin{array}{l}\text { Pumping } \\
\text { rate } \\
\text { during } \\
\text { flow } \\
\text { logging } \\
\text { (gal/min) } \\
\end{array}$ & $\begin{array}{l}\text { Draw- } \\
\text { down at } \\
\text { end of } \\
\text { pumping } \\
\text { (ft) }\end{array}$ & $\begin{array}{c}\text { Specific } \\
\text { capacity } \\
{[(\mathrm{gal} / \mathrm{min}) /} \\
\mathrm{ft}]\end{array}$ & Notes \\
\hline BK 962 & WMA & NAWC10 & 401144.51 & 750443.51 & 50 & 385 & 8 & $12 / 1 / 2017$ & 13.95 & 2 & 0.19 & 10.53 & -- \\
\hline BK 1023 & WMA & Well 28 & 401138.26 & 0750310.45 & 57 & 604 & 8 & $9 / 6 / 2018$ & 29.53 & -- & -- & -- & Severe deviation \\
\hline BK 1087 & WMA & Well 25 & 401232.89 & 750409.71 & 60 & 400 & 8 & $8 / 10 / 2018$ & 13.39 & 1 & 1.52 & 0.66 & -- \\
\hline BK 1129 & WMA & Well 36 & 401247.47 & 750542.53 & 50 & 375 & 12 & $9 / 5 / 2018$ & $<-1.8$ & -- & -- & -- & $\begin{array}{l}\text { Flowing at } 8 \mathrm{gal} / \\
\min \end{array}$ \\
\hline BK 2698 & WTWSA & Well 8 & 401317.58 & 750429.61 & 60 & 210.5 & 10 & $9 / 10 / 2019$ & -0.35 & 2 & 0.81 & 2.47 & -- \\
\hline BK 2861 & WTWSA & Well 11 & 401317.96 & 750430.33 & 83 & 160 & 10 & $9 / 12 / 2019$ & 1.9 & 1.7 & 0.51 & 3.33 & -- \\
\hline BK 2869 & WTWSA & Well 9 & 401322.12 & 750505.33 & 63 & 315 & 10 & 6/17-18/2019 & 17.93 & 1.1 & 1.02 & 1.08 & 12 -in. to $85 \mathrm{ft}$ \\
\hline BK 2870 & WTWSA & Well 10 & 401324.00 & 750508.82 & 61 & 270 & 10 & $9 / 11 / 2019$ & 27.88 & 1.8 & 0.32 & 5.63 & $\begin{array}{l}\text { Pipe at } 63.2 \mathrm{ft}, \\
\text { rocks at } 85 \mathrm{ft}\end{array}$ \\
\hline BK 3062 & NBCMA & Well 15 & 401210.71 & 750205.35 & 93 & 400 & 10 & $11 / 28-29 / 2017$ & 28.8 & 2 & 2.25 & 0.89 & -- \\
\hline BK 3063 & Navy & HN-116 & 401213.87 & 750447.38 & 19 & 601 & 6 & $5 / 24-25 / 2018$ & 8.22 & 5 & -- & -- & -- \\
\hline BK 3066 & Navy & HN-118 & 401218.67 & 750327.27 & 19 & 602 & 6 & $8 / 6-7 / 2018$ & 29.3 & 2 & -- & -- & -- \\
\hline BK 3067 & Navy & HN-119 & 401213.68 & 750239.77 & 20 & 602 & 6 & $8 / 8 / 2018$ & 55 & -- & -- & -- & Cascading water \\
\hline BK 3068 & Navy & HN-117 & 401214.18 & 750409.81 & 19 & 600 & 6 & $8 / 9 / 2018$ & 15.35 & 2.5 & 0.2 & 12.50 & -- \\
\hline BK 3070 & Navy & HN-120D & 401142.35 & 750336.85 & 59 & 555 & 6 & $10 / 31 / 2018$ & 15.44 & 1.8 & 0.2 & 9.00 & $\begin{array}{l}\text { 600-ft hole } \\
\text { collapsed at } \\
555 \mathrm{ft}\end{array}$ \\
\hline BK 3071 & Navy & $\mathrm{HN}-121$ & 401143.33 & 750421.23 & 20 & 415 & 6 & $11 / 1 / 2018$ & 11.6 & 1.7 & 0.05 & 34.00 & $\begin{array}{l}\text { 600-ft hole } \\
\text { collapsed at } \\
415 \mathrm{ft}\end{array}$ \\
\hline \multicolumn{14}{|c|}{ Wells with partial logs } \\
\hline BK 1058 & WMA & Well 27 & 401031.40 & 750440.13 & 58 & 485 & 8 & $9 / 6 / 2018$ & 23.92 & -- & -- & -- & $\begin{array}{l}\text { Partial suite of } \\
\quad \log _{s}\end{array}$ \\
\hline BK 3069 & Navy & HN-120S & 401142.25 & 750336.50 & 19 & 26 & 6 & -- & 12.6 & -- & -- & -- & $\begin{array}{l}\text { Video log only; } \\
\text { collapsed hole }\end{array}$ \\
\hline
\end{tabular}

${ }^{1}$ Latitude and longitude for well location from the Global Positioning System (GPS) except for wells BK-1023, BK-2698, BK-2870, and BK-3062, which were located using Google Earth; all locations reported relative to North American Datum 1983. 
Table 3. Type and dates of geophysical and video logs collected and archived by U.S. Geological Survey at and near Naval Air Warfare Center Warminster, Bucks County, Pennsylvania, 2017-19.

[WMA, Warminster Municipal Authority; WTWSA, Warwick Township Water and Sewer Authority; NBCMA, Northampton Bucks County Municipal Authority; Acoustic cal, acoustic caliper; M, D, medium and deep; EM, electromagnetic; Ind Cond, EM-induction conductivity; Ind Res, EM-induction resistivity; COND, conductivity; RES, resistivity; RES(16N), RES (64N), short, long-normal resistivity; RES(SP), single-point resistance; ATV, acoustic televiewer; OTV, optical televiewer; Tilt ATV, borehole tilt from ATV tool; Azi, azimuth of borehole tilt; TEMP, fluid temperature; RES(FL), fluid resistivity; EMFM, EM flowmeter; HPFM, heat-pulse flowmeter; amb, ambient; pmp, pumping; --, no data or not collected]

\begin{tabular}{|c|c|c|c|c|c|c|c|c|c|c|c|c|c|c|c|c|c|c|c|c|c|c|c|}
\hline $\begin{array}{c}\text { USGS } \\
\text { local } \\
\text { well } \\
\text { name }\end{array}$ & $\begin{array}{c}\text { Owner } \\
\text { well } \\
\text { name }\end{array}$ & USGS site ID & $\begin{array}{c}\text { Date(s) of } \\
\text { geophysical } \\
\text { logs }\end{array}$ & $\begin{array}{l}\text { Date(s) of } \\
\text { video log }\end{array}$ & $\begin{array}{l}\text { Cali- } \\
\text { per }\end{array}$ & $\begin{array}{c}\text { Acou } \\
\text { cal }\end{array}$ & $\begin{array}{c}\text { Gam- } \\
\text { ma }\end{array}$ & $\begin{array}{c}\text { M, D Inc } \\
\text { Cond; } \\
\text { M, D } \\
\text { Ind } \\
\text { Res }\end{array}$ & $\begin{array}{c}\text { COND } \\
\text { RES }\end{array}$ & $\begin{array}{c}\text { RES } \\
(16 N) \\
\text { RES } \\
(64 N)\end{array}$ & $\begin{array}{l}\text { RES } \\
\text { (SP) }\end{array}$ & $\begin{array}{l}\text { ATV } \\
\text { im- } \\
\text { age }\end{array}$ & $\begin{array}{l}\text { OTV } \\
\text { Res } \\
\text { im- } \\
\text { age }\end{array}$ & $\begin{array}{l}\text { Tilt } \\
\text { ATV }\end{array}$ & Azi & $\begin{array}{c}\text { TEMP } \\
\text { amb }\end{array}$ & $\begin{array}{l}\text { RES } \\
\text { (FL) } \\
\text { amb }\end{array}$ & $\begin{array}{c}\text { TEMP } \\
\text { pmp }\end{array}$ & $\begin{array}{l}\text { RES } \\
\text { (FL) } \\
\text { pmp }\end{array}$ & $\begin{array}{c}\text { EMFM } \\
\text { amb }\end{array}$ & $\begin{array}{c}\text { HPFM } \\
\text { amb }\end{array}$ & $\begin{array}{c}\text { EMFM } \\
\text { pmp }\end{array}$ & $\begin{array}{c}\text { HPFM } \\
\text { pmp }\end{array}$ \\
\hline \multicolumn{24}{|c|}{ WMA wells } \\
\hline BK 962 & $\begin{array}{c}\text { NAWC } \\
10\end{array}$ & 401146075041101 & $12 / 1 / 2017$ & $\begin{array}{c}11 / 28 / 2017 \\
4 / 12 / 2018\end{array}$ & $\mathrm{x}$ & -- & $\mathrm{x}$ & $\mathrm{x}^{1}$ & -- & $\mathrm{x}$ & -- & $\mathrm{x}$ & $\mathrm{x}$ & $\mathrm{x}$ & $\mathrm{x}$ & $\mathrm{x}$ & $\mathrm{x}$ & $\mathrm{x}$ & $\mathrm{x}$ & $\mathrm{x}$ & -- & $\mathrm{x}$ & -- \\
\hline BK 1023 & Well 28 & 401137075031301 & $9 / 6 / 2018$ & $\begin{array}{c}9 / 15 / 2018 \\
10 / 3 / 2018\end{array}$ & $\mathrm{x}$ & $\mathrm{x}$ & $\mathrm{x}$ & $\mathrm{x}$ & -- & -- & -- & $\mathrm{x}$ & $\mathrm{x}$ & $\mathrm{x}$ & $\mathrm{x}$ & $\mathrm{x}$ & $\mathrm{x}$ & -- & -- & $\mathrm{x}$ & -- & -- & -- \\
\hline BK 1058 & Well 27 & 401030075044001 & $9 / 6 / 2018$ & $8 / 30 / 2018$ & $\mathrm{x}$ & $\mathrm{x}$ & -- & -- & -- & -- & -- & $\mathrm{x}$ & $\mathrm{x}$ & $\mathrm{x}$ & $\mathrm{x}$ & -- & -- & -- & -- & -- & -- & -- & -- \\
\hline BK 1087 & Well 25 & 401232075041001 & $8 / 10 / 2018$ & $8 / 29 / 2018$ & $\mathrm{x}$ & $\mathrm{x}$ & -- & $\mathrm{x}$ & -- & -- & -- & $\mathrm{x}$ & $\mathrm{x}$ & $\mathrm{x}$ & $\mathrm{x}$ & $\mathrm{x}$ & $\mathrm{x}$ & $\mathrm{x}$ & $\mathrm{x}$ & $\mathrm{x}$ & -- & $\mathrm{x}$ & -- \\
\hline \multicolumn{24}{|c|}{ WTSA wells } \\
\hline BK 1129 & Well 36 & 401247075054501 & $9 / 5 / 2018$ & $6 / 21 / 2018$ & $\mathrm{x}$ & $\mathrm{x}$ & $\mathrm{x}$ & $\mathrm{x}$ & -- & -- & -- & $\mathrm{x}$ & $\mathrm{x}$ & $\mathrm{x}$ & $\mathrm{x}$ & $\mathrm{x}$ & $\mathrm{x}$ & -- & -- & $\mathrm{x}$ & -- & -- & -- \\
\hline BK 2698 & Well 8 & 401317075043101 & $9 / 10 / 2019$ & $8 / 27 / 2019$ & $\mathrm{x}$ & -- & $\mathrm{x}$ & -- & $\mathrm{x}$ & -- & -- & $\mathrm{x}$ & $\mathrm{x}$ & $\mathrm{x}$ & $\mathrm{x}$ & $\mathrm{x}$ & $\mathrm{x}$ & $\mathrm{x}$ & $\mathrm{x}$ & -- & $\mathrm{x}$ & -- & $\mathrm{x}$ \\
\hline BK 2861 & Well 11 & 401318075043201 & $9 / 12 / 2019$ & $8 / 6 / 2019$ & $\mathrm{x}$ & -- & $\mathrm{x}$ & -- & $\mathrm{x}$ & -- & -- & $\mathrm{x}$ & $x^{2}$ & $\mathrm{x}$ & $\mathrm{x}$ & $\mathrm{x}$ & $\mathrm{x}$ & $\mathrm{x}$ & $\mathrm{x}$ & -- & $\mathrm{x}$ & -- & $\mathrm{x}$ \\
\hline BK 2869 & Well 9 & 401322075050501 & 6/17-18/2019 & $7 / 25 / 2019$ & $\mathrm{x}$ & -- & $\mathrm{x}$ & -- & $\mathrm{x}$ & -- & -- & $\mathrm{x}$ & $x^{2}$ & $\mathrm{x}$ & $\mathrm{x}$ & $\mathrm{x}$ & $\mathrm{x}$ & $\mathrm{x}$ & $\mathrm{x}$ & -- & $\mathrm{x}$ & -- & $\mathrm{x}$ \\
\hline BK 2870 & Well 10 & 401324075050701 & $9 / 11 / 2019$ & $8 / 9 / 2019$ & $\mathrm{x}$ & -- & $\mathrm{x}$ & -- & $\mathrm{x}$ & -- & -- & $\mathrm{x}$ & -- & $\mathrm{x}$ & $\mathrm{x}$ & $\mathrm{x}$ & $\mathrm{x}$ & $\mathrm{x}$ & $\mathrm{x}$ & -- & $\mathrm{x}$ & -- & $\mathrm{x}$ \\
\hline \multicolumn{24}{|c|}{ NBMCA wells } \\
\hline BK 3062 & Well 15 & 401214075044701 & $11 / 28-29 / 2017$ & $11 / 9 / 2017$ & $\mathrm{x}$ & -- & $\mathrm{x}$ & $\mathrm{x}$ & -- & $\mathrm{x}$ & -- & $\mathrm{x}$ & $\mathrm{x}$ & $\mathrm{x}$ & $\mathrm{x}$ & $\mathrm{x}$ & $\mathrm{x}$ & $\mathrm{x}$ & $\mathrm{x}$ & $\mathrm{x}$ & -- & $\mathrm{x}$ & -- \\
\hline \multicolumn{24}{|c|}{ Navy wells } \\
\hline BK 3063 & $\mathrm{HN}-116$ & 401214075044701 & $5 / 24-25 / 2018$ & $5 / 21 / 2018$ & $\mathrm{x}$ & $\mathrm{x}$ & $\mathrm{x}$ & $\mathrm{x}$ & -- & $\mathrm{x}$ & $\mathrm{x}$ & $\mathrm{x}$ & $\mathrm{x}$ & $\mathrm{x}$ & $\mathrm{x}$ & $\mathrm{x}^{3}$ & $\mathrm{x}^{3}$ & $\mathrm{x}$ & $\mathrm{x}$ & $\mathrm{x}^{3}$ & -- & $\mathrm{x}$ & -- \\
\hline BK 3066 & HN-118 & 401219075032701 & $8 / 6-7 / 2018$ & $8 / 2 / 2018$ & $\mathrm{x}$ & $\mathrm{x}$ & $\mathrm{x}$ & $\mathrm{x}$ & -- & -- & -- & $\mathrm{x}$ & $\mathrm{x}$ & $\mathrm{x}$ & $\mathrm{x}$ & $\mathrm{x}$ & $\mathrm{x}$ & $\mathrm{x}$ & $\mathrm{x}$ & $\mathrm{x}$ & -- & $\mathrm{x}$ & -- \\
\hline BK 3067 & HN-119 & 401214075024001 & $8 / 8 / 2018$ & $8 / 6 / 2018$ & $\mathrm{x}$ & $\mathrm{x}$ & $\mathrm{x}$ & $\mathrm{x}$ & -- & -- & -- & $\mathrm{x}$ & $\mathrm{x}$ & $\mathrm{x}$ & $\mathrm{x}$ & $\mathrm{x}$ & $\mathrm{x}$ & -- & -- & $\mathrm{x}$ & -- & -- & -- \\
\hline BK 3068 & $\mathrm{HN}-117$ & 401214075041001 & $8 / 9 / 2018$ & $8 / 28 / 2018$ & $\mathrm{x}$ & $\mathrm{x}$ & $\mathrm{x}$ & $\mathrm{x}$ & -- & -- & -- & $\mathrm{x}$ & $\mathrm{x}$ & $\mathrm{x}$ & $\mathrm{x}$ & $\mathrm{x}$ & $\mathrm{x}$ & $\mathrm{x}$ & $\mathrm{x}$ & $\mathrm{x}$ & -- & $\mathrm{x}$ & -- \\
\hline BK 3069 & $\mathrm{HN}-\mathrm{OS}$ & 401142075033601 & -- & $11 / 7 / 2018$ & -- & -- & -- & -- & -- & -- & -- & -- & -- & -- & -- & -- & -- & -- & -- & -- & -- & -- & -- \\
\hline BK 3070 & $\mathrm{HN}-0 \mathrm{D}$ & 401142075033701 & $10 / 31 / 2018$ & $10 / 31 / 2018$ & $\mathrm{x}$ & $\mathrm{x}$ & $\mathrm{x}$ & $\mathrm{x}$ & -- & -- & -- & $\mathrm{x}$ & $\mathrm{x}$ & $\mathrm{x}$ & $\mathrm{x}$ & $\mathrm{x}$ & $\mathrm{x}$ & $\mathrm{x}$ & $\mathrm{x}$ & $\mathrm{x}$ & -- & $\mathrm{x}$ & -- \\
\hline BK 3071 & $\mathrm{HN}-121$ & 401143075042101 & $11 / 1 / 2018$ & $10 / 6 / 2018$ & $\mathrm{x}$ & $\mathrm{x}$ & $\mathrm{x}$ & $\mathrm{x}$ & -- & -- & -- & $\mathrm{x}$ & $\mathrm{x}$ & $\mathrm{x}$ & $\mathrm{x}$ & $\mathrm{x}$ & $\mathrm{x}$ & $\mathrm{x}$ & $\mathrm{x}$ & $\mathrm{x}$ & -- & $\mathrm{x}$ & -- \\
\hline
\end{tabular}

IInduction resistivity not calculated from induction conductivity log in archived data for well BK-962.

${ }^{2}$ Low borehole visibility prevented collection of useable OTV.

${ }^{3}$ Fluid logs collected during ambient conditions with and without nearby extraction wells pumping. 
pumping were also recorded and used to calculate the specific capacity of the well (table 2). Depths of logs, observed features, and water levels are reported in feet below land surface (ft bls).

The type of geophysical logs collected for each well is summarized in table 3 . Abbreviations for logs and reporting units in table 3 and in log figures are listed in table 1. Digital data for the type of geophysical log collected for each well as summarized in table 3, except for the OTV and ATV logs, are available online from the USGS GeoLog Locator (U.S. Geological Survey, 2020); the OTV and ATV logs are available as images. The OTV and ATV log digital data are archived locally by the USGS New York Water Science Center. The borehole video logs are archived locally by the USGS Pennsylvania Water Science Center.

\section{Interpretation of Individual Well Geophysical and Video Logs}

For each well, borehole characteristics, vertical borehole flow directions under ambient conditions, and identification of probable hydraulically active water-bearing zones as determined from evaluation of the geophysical log suite are briefly described. Commonly (but not always), the most hydraulically active water-bearing fractures identified from the logs may also be the most productive water-bearing fractures. Other water-bearing fractures likely are present in the wells. Selected probable or possible water-bearing fractures and other features as observed on borehole video logs are noted.

The distribution and orientation of the probable hydraulically active fractures are presented as tadpole plots relative to magnetic north within the suite of geophysical logs in the sections that follow for each well and with stereonet plots (appendix 1). During the 2018-19 period of logging, magnetic declination (angle between true north and horizontal trace of magnetic field) was about -12 degrees 8 minutes, ranging from -12 degrees 6 minutes to -12 degrees 10 minutes depending on year and magnetic model as calculated using National Oceanic and Atmospheric Administration (2020) online tool.

\section{BK-962 (NAWC 10)}

Well BK-962 is a former production well (NAWC 10) for the NAWC Warminster base (figs. 1 and 3); it was transferred to Warminster Municipal Authority when the base closed and is no longer in use, partly because of elevated manganese concentrations (Timothy Hagey, Warminster Municipal Authority, oral commun., 2018). Prior to logging by USGS, the pump and plumbing were removed in fall 2017. The well has 10 -in. diameter casing to a depth of about $50 \mathrm{ft}$ bls and below that depth is an 8-in. diameter open hole to about $385 \mathrm{ft}$ bls (table 2). The depth to static water level at the time of logging was about $13.95 \mathrm{ft}$ bls.
The caliper and ATV logs show numerous fractures throughout the borehole (fig. 4). Most of the fractures appear to be low-angle, although the ATV indicates the presence of high-angle fractures at about 80,170 , and $200 \mathrm{ft}$ bls. The fluidtemperature log shows the largest inflections at about 80 and $200 \mathrm{ft}$ bls and the fluid-conductivity log shows small inflections at similar depths. The flow log collected under ambient conditions indicates upward flow from near the bottom of the borehole to about $200 \mathrm{ft}$ bls, where water may be exiting the borehole (or where flow measurements may be lower than actual because of possible bypass around diverters), and then an increase in upward flow above $166 \mathrm{ft}$ bls (table 4). The flow log collected under pumping conditions indicated that the fractures above $166 \mathrm{ft}$ bls are the most hydraulically active water-bearing zones in the well.

The borehole video log, collected by USGS on November 28, 2017, when the water level was $13.8 \mathrm{ft}$ bls, showed some horizontal and numerous vertical fractures throughout the borehole. Apparent turbulence was at about 167.8-174, 195.8-201, 210, and $262.8 \mathrm{ft}$ bls and water appeared to be injecting into the borehole at $152.1 \mathrm{ft}$ bls. Possible primary water-bearing zones were noted for fractures at about 76.6-79.4, 152.1, 167.8-174, and $196.5 \mathrm{ft}$ bls. Videolog images for selected fractures in well BK-962 are shown in figure 5.

\section{BK-1023 (WMA Well 28)}

Well BK-1023 is an unused test well (WMA well 28 on the southeast edge of the former NAWC Warminster base (figs. 1 and 3). Prior to logging by USGS, a large tree growing into the casing and obstructing access to the well was removed by WMA. The well has 8 -in. diameter casing to a depth of about $57 \mathrm{ft}$ bls and below that depth is an 8-in. diameter open hole to about $604 \mathrm{ft}$ bls (table 2). The depth to ambient water level at the time of logging was about $29.5 \mathrm{ft}$ bls. The well is strongly deviated from vertical.

The caliper and ATV logs show fractures are present throughout the borehole, with the largest openings at depths above $200 \mathrm{ft}$ bls (fig. 6). The fluid-temperature log shows decreasing temperature to about $350 \mathrm{ft}$ bls, then increasing temperature below that depth to the bottom of the well at 604 $\mathrm{ft}$. The fluid temperature $\log$ also shows small inflections at depths above $125 \mathrm{ft}$ bls with a change in slope near $115 \mathrm{ft}$ bls. The fluid-conductivity log shows the largest inflection at about $75 \mathrm{ft}$ bls and appears almost constant below $100 \mathrm{ft}$ bls. The flow log collected under ambient conditions indicates downward flow throughout the borehole starting from depths between 45 and $72 \mathrm{ft}$ bls that increases below $82 \mathrm{ft}$ bls and increases again at depths between 194 and $240 \mathrm{ft}$ bls (table 5). The ambient fluid and flow logs indicate that water-bearing zones above $225 \mathrm{ft}$ bls probably are the most hydraulically active in the well. The flow and fluid logs were not collected under pumping conditions. 


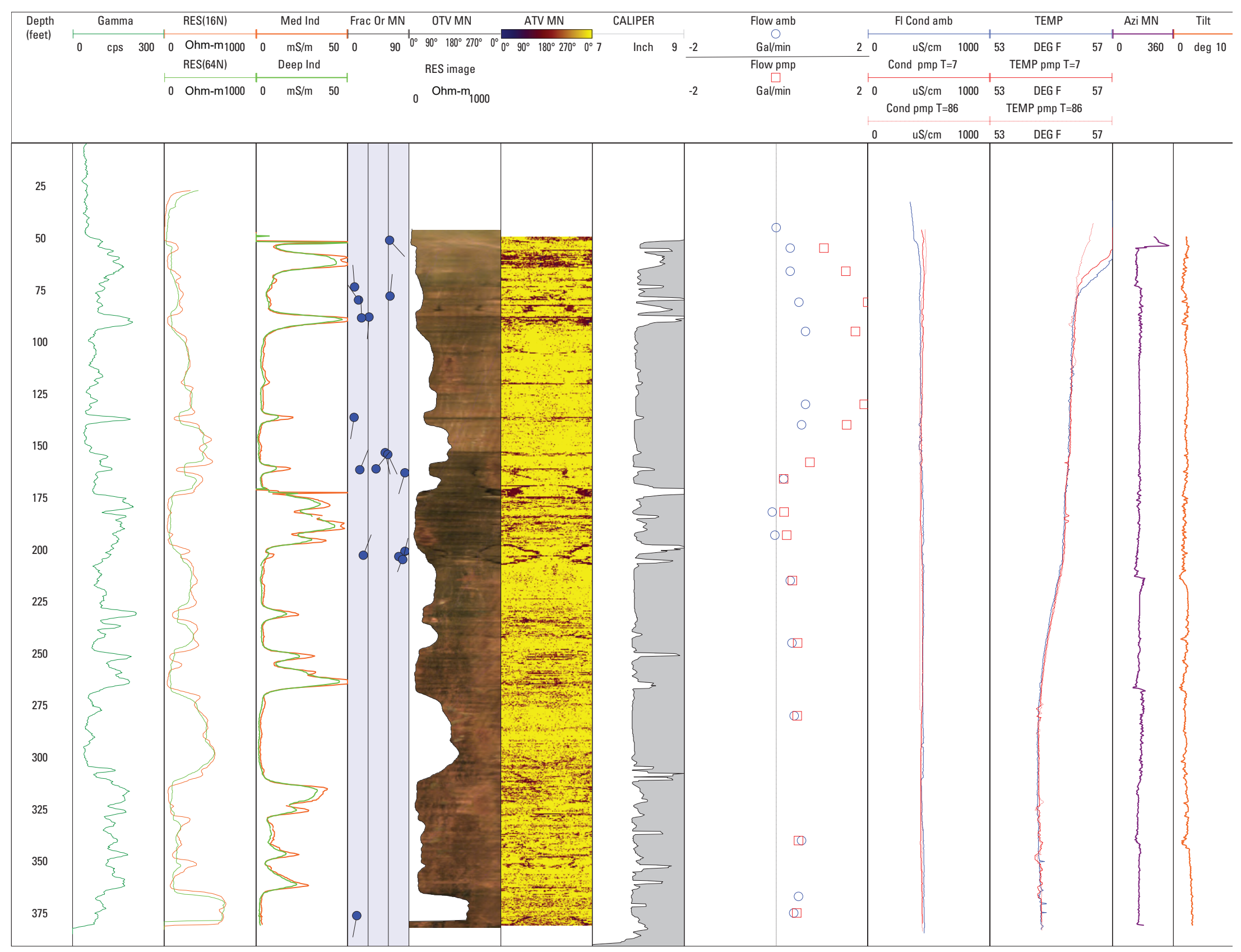

Figure 4. Geophysical logs collected by U.S. Geological Survey in well BK-962 (NAWC well 10), Warminster Township, Bucks County, Pennsylvania, December 1, 2017. See table 1 for explanation of abbreviations. 
Table 4. Borehole flow-measurements collected by U.S. Geological Survey in well BK-962 (NAWC well 10), Warminster Township, Bucks County, Pennsylvania, December 1, 2017. Stationary measurements made using the electromagnetic flow meter under ambient and pumping conditions; negative values indicate downward flow and positive values indicate upward flow. Flow values reported in table reflect corrections to raw measurements based on zero flow in casing under ambient conditions and known flow in casing under pumping conditions.

[ft, feet; bls, below land surface; corr, corrected value; gal/min, gallons per minute; amb, ambient conditions; pmp, pumping conditions; --, no data]

\begin{tabular}{cccc}
\hline \multicolumn{2}{c}{ Ambient conditions } & \multicolumn{2}{c}{ Pumping conditions } \\
\hline Depth (ft bls) & $\begin{array}{c}\text { Flow amb, corr } \\
\text { (gal/min) }\end{array}$ & Depth (ft bls) & $\begin{array}{c}\text { Flow pmp1, corr } \\
\text { (gal/min) }\end{array}$ \\
\hline 45 & 0.00 & 45 & -- \\
55 & 0.32 & 55 & 1.05 \\
66 & 0.32 & 66 & 1.52 \\
81 & 0.50 & 81 & 2.00 \\
95 & 0.65 & 95 & 1.73 \\
130 & 0.65 & 130 & 1.93 \\
140 & 0.56 & 140 & 1.54 \\
158 & -- & 158 & 0.74 \\
166 & 0.17 & 166 & 0.17 \\
182 & -0.09 & 182 & 0.18 \\
193 & -0.03 & 193 & 0.24 \\
215 & 0.32 & 215 & 0.36 \\
245 & 0.35 & 245 & 0.47 \\
280 & 0.39 & 280 & 0.46 \\
340 & 0.55 & 340 & 0.49 \\
367 & 0.49 & 367 & -- \\
375 & 0.39 & 375 & 0.45 \\
\hline
\end{tabular}

${ }^{1}$ Pumping rate $=2 \mathrm{gal} / \mathrm{min}$; drawdown $=0.19 \mathrm{ft}$; start pump at 11:08, stop at 12:30; well may be affected by other nearby pumping.

The borehole video log, collected by USGS on October 3 , 2018, when the water level was $27.3 \mathrm{ft}$ bls, showed few notable horizontal and vertical fractures throughout the borehole. Possible principal water-bearing zones were noted for fractures at about 164 and $197.5 \mathrm{ft}$ bls. Video-log images for selected fractures or openings in well BK-1023 are shown in figure 7. Although not identified as principal water-bearing fractures in video log notes, fractures near $62 \mathrm{ft}$ and $74 \mathrm{ft} \mathrm{bls}$ (fig. 7A,B) appear to be water bearing as indicated by other geophysical logs.

\section{BK-1058 (WMA Well 27)}

Well BK-1058 is an unused test well (WMA well 27) about $1.2 \mathrm{mi}$ south of the former NAWC Warminster base (figs. 1 and 3). The well has 8-in. diameter casing to a depth of about $58 \mathrm{ft}$ bls and below that depth is an 8 -in. diameter open hole to about $485 \mathrm{ft}$ bls (table 2). The depth to ambient water level at the time of logging was about $23.9 \mathrm{ft}$ bls.

Limited logs were collected in well BK-1058 (table 3) in 2018, which was not selected for further evaluation and straddle packer testing in 2018. Data for the 2018 logs collected from well BK-1058 are available online from the USGS GeoLog Locator (U.S. Geological Survey, 2020). Caliper, gamma, single-point resistance, fluid-temperature, and fluidresistivity logs were previously collected by USGS for this well in 1995.

The 2018 caliper and ATV logs show numerous fractures throughout the borehole, including at depths near 60 , 70-80, 182, 250-257, 280-290, 300, 335, 355-383, 387-400, $425-443$, and $472-480 \mathrm{ft}$ bls. No fluid or flow logs were collected in well BK-1058 in 2018.

The borehole video log, collected by USGS on August 30, 2018, when the water level was $23.6 \mathrm{ft}$ bls, showed numerous horizontal and vertical fractures throughout the borehole. Possible principal water-bearing zones were noted for fractures at about 79.4, 99.6, 100.8-102.0, 252, 351, 387.5, and $391 \mathrm{ft}$ bls. Other possible water-bearing fractures were noted in the borehole, including near 60, 72.2, 75.8, 11.4, 139.3-146, 180.1, 229.8, 277.3, 2. 285.6, 294.1, 333.8, 337.8, 385.7 , and $387.5 \mathrm{ft}$ bls. Visibility decreased with depth below $180 \mathrm{ft}$ bls. At depths greater than $391 \mathrm{ft}$ bls, visibility was poor and video log was ended. Water was observed to be injecting into borehole near fractures at $99.6 \mathrm{ft}$ bls and turbulence was observed near fractures at 100.8-102 ft bls. Possible turbulence was also noted near fractures at $139.3-146 \mathrm{ft}$ bls.

\section{BK-1087 (WMA Well 25)}

Well BK-1087 is an unused test well (WMA well 25) about 0.2 mi north of the former NAWC Warminster base (figs. 1 and 3). The well has 8-in. diameter casing to a depth of about $60 \mathrm{ft}$ bls and below that depth is an 8-in. diameter open hole to about $400 \mathrm{ft}$ bls (table 2). Depth to ambient water level at the time of logging was about $13.4 \mathrm{ft}$ bls.

The caliper and ATV logs show numerous fractures throughout the borehole, with the largest openings at depths above $125 \mathrm{ft}$ bls (fig. 8). Most of the fractures appear to be low-angle, although the ATV indicates the presence of high-angle fractures at about 240 and $275 \mathrm{ft}$ bls. The fluidtemperature log collected under ambient conditions shows the largest inflections at about 100 and $275 \mathrm{ft}$ bls, with temperature decreasing below water level to about $100 \mathrm{ft}$ bls and increasing slightly below $275 \mathrm{ft}$ bls. The fluid-conductivity log collected under ambient and pumping conditions indicates an inflection at about $100 \mathrm{ft}$ bls that likely corresponds to a waterbearing zone. The flow log collected under ambient conditions indicates possible slight upward flow starting from near the bottom of the borehole at $360 \mathrm{ft}$ bls to about $330 \mathrm{ft}$ bls and possible slight downward flow below $50 \mathrm{ft}$ bls to about $140 \mathrm{ft}$ bls (table 6). The flow log collected under pumping conditions 

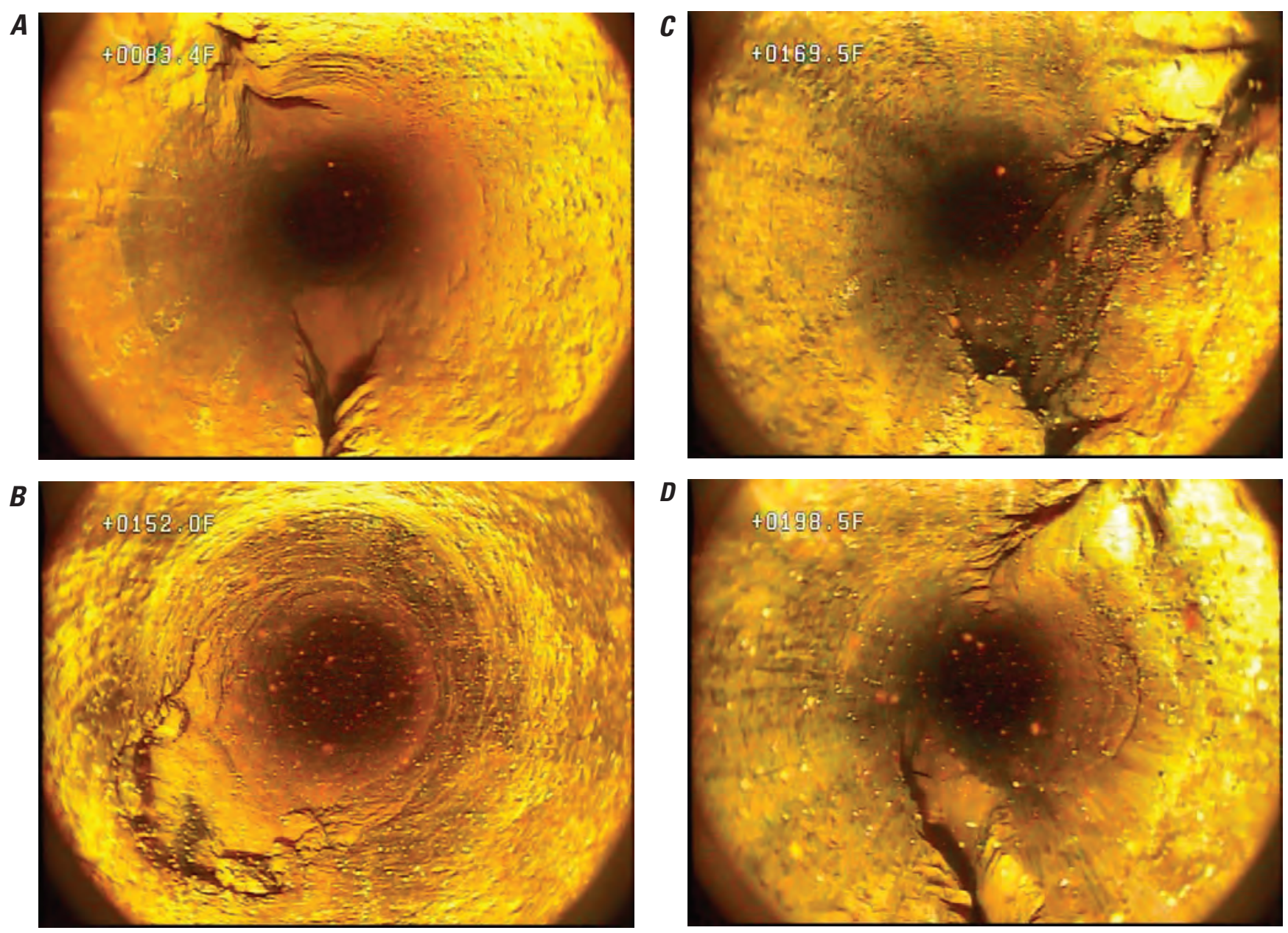

Figure 5. Still images from borehole video log of well BK-962 (NAWC 10) at $A, 83.4$ feet below land surface (ft bls) showing high-angle fractures, $B, 152.0 \mathrm{ft}$ bls showing oblique opening where water appeared to be injecting into the borehole, $C, 169.5 \mathrm{ft}$ bls showing vertical fractures crossing side of borehole, and $D, 198.5 \mathrm{ft}$ bls showing high-angle fractures. Video log collected by U.S. Geological Survey in well BK-962, Warminster Township, Bucks County, Pennsylvania, November 28, 2017.

indicated that the fractures above $105 \mathrm{ft}$ bls (and specifically the fracture at about $100 \mathrm{ft}$ bls) are the most hydraulically active water-bearing zones in the well.

The borehole video log, collected by USGS on August 29, 2018, when the water level was $14.6 \mathrm{ft}$ bls, showed numerous horizontal and vertical fractures throughout the borehole. Possible water-bearing zones were noted for fractures at about $234.1-245.7 \mathrm{ft}$ bls and the likely water-bearing fracture near $100 \mathrm{ft}$ bls; other possible water-bearing fractures also were noted, including fractures near 127, 192-197, 271, and 332-334 ft bls. At $366.4 \mathrm{ft}$ bls, the well appears to be blocked with pipes that may have fallen to the bottom of the borehole at an unknown time but prior to this investigation in 2018. Video-log images for selected fractures or openings in well BK-1087 are shown in figure 9.

\section{BK-1129 (Warminster Well 36)}

Well BK-1129 is a formerly active production well (WMA well 36) northwest of the former NAWC Warminster base (figs. 1 and 3 ) and scheduled for abandonment, partly because of high dissolved solids. The well has 12-in. diameter casing to a depth of about $58 \mathrm{ft}$ bls and below that depth is a 12 -in. diameter open hole to about $375 \mathrm{ft}$ bls (table 2). The well was flowing at a rate of about $8 \mathrm{gal} / \mathrm{min}$ out of a pipe at the top of casing $1.8 \mathrm{ft}$ above land surface at the time of logging.

The caliper and ATV logs show numerous fractures throughout the borehole, with the most numerous openings at depths above $275 \mathrm{ft}$ bls (fig. 10). Most of the fractures appear to be low-angle, although the ATV indicates the presence of high-angle fractures at about 210, 240, and 325 $\mathrm{ft}$ bls. The fluid-temperature log collected under ambient conditions shows almost no to very slight inflections. The 


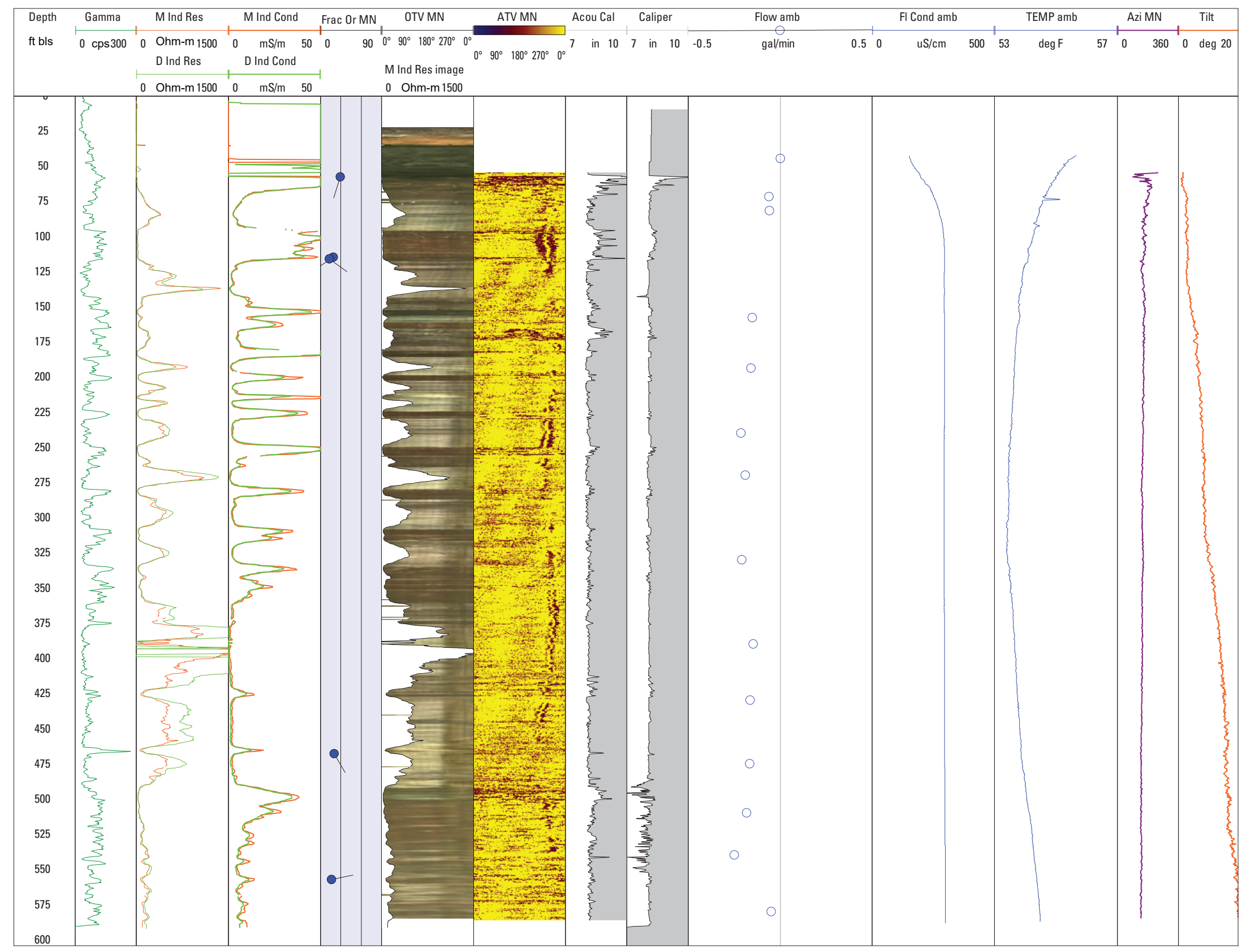

Figure 6. Geophysical logs collected by U.S. Geological Survey in well BK-1023 (WMA well 28), Warminster Township, Bucks County, Pennsylvania, September 6, 2018. See table 1 for explanation of abbreviations. 
Table 5. Borehole flow-measurements collected by U.S. Geological Survey in well BK-1023 (WMA well 28), Warminster Township, Bucks County, Pennsylvania, September 6, 2018. Stationary measurements made using an electromagnetic flow meter under ambient conditions; negative values indicate downward flow and positive values indicate upward flow. No flow metering was done under pumping conditions for BK 1023.

[ft, feet; bls, below land surface; gal/min, gallons per minute; amb, ambient conditions; pmp, pumping conditions]

\begin{tabular}{|c|c|}
\hline \multicolumn{2}{|c|}{ Ambient conditions } \\
\hline Depth (ft bls) & Flow amb (gal/min) \\
\hline 45 & 0.00 \\
\hline 72 & -0.06 \\
\hline 82 & -0.06 \\
\hline 158 & -0.15 \\
\hline 194 & -0.16 \\
\hline 240 & -0.21 \\
\hline 270 & -0.19 \\
\hline 330 & -0.21 \\
\hline 390 & -0.15 \\
\hline 430 & -0.16 \\
\hline 475 & -0.17 \\
\hline 510 & -0.18 \\
\hline 540 & -0.25 \\
\hline 580 & -0.05 \\
\hline
\end{tabular}

fluid-conductivity log collected under ambient conditions shows the largest inflections near about 175, 250, and 360 $\mathrm{ft}$ bls that probably correspond to water-bearing zones. The flow log collected under ambient conditions indicates upward flow throughout the borehole starting from near the bottom of the borehole above $370 \mathrm{ft}$ bls, and increasing in magnitude at depths above $320,265,177,168,120,74$, and above $58 \mathrm{ft}$ bls (table 7). The flow and fluid logs collected under ambient conditions indicate that water-bearing zones near depths of 160 and $360 \mathrm{ft}$ bls likely are the most hydraulically active, although water-bearing zones above 74 and near 100, 175, 255 , and $310 \mathrm{ft}$ bls also appear to produce water. The flow measurements are uncertain because the heat-pulse flowmeter was equipped with an 8-in. diverter in a 12-in. diameter borehole that allows an unquantified amount of flow to bypass the meter, especially in sections of borehole with varying diameter, and thus should be interpreted with caution. The flow and fluid logs were not collected under pumping conditions.

The borehole video log, collected by USGS on June 21, 2018, when the well was flowing, showed numerous horizontal fractures throughout the borehole. Possible principal waterbearing zones were noted for fractures at about 160.5-162 and $176 \mathrm{ft}$ bls. Other possible water-bearing fractures indicated by geophysical logs also included those observed at depths of about 237-242, 255, 310.7-314, and $357 \mathrm{ft}$ bls, in addition to numerous fractures at depths of about $61-110 \mathrm{ft}$ bls. Video-log images for selected fractures or openings in well BK-1129 are shown in figure 11.

\section{BK-2698 (WTWSA Well 8)}

Well BK-2698 is an unused production well (WTWSA well 8) about 1.3 mi north of the former NAWC Warminster base (figs. 1 and 3). Prior to logging by USGS, the pump and plumbing were removed in summer 2019. The well has 10-in. diameter casing to a depth of about $60 \mathrm{ft}$ bls and below that depth is a 10 -in. diameter open hole to about $210.5 \mathrm{ft}$ bls (table 2). The depth to ambient water level at the time of logging in September 2019 was about $0.35 \mathrm{ft}$ above land surface. Well BK-2698 was logged previously in the 1990s by USGS (Bird, 1998, p. 13).

The caliper and ATV logs show a few fractures throughout the borehole, with the largest openings at about $110 \mathrm{ft}$ bls. Most of the fractures appear to be low angle (fig. 12). The fluid-temperature log collected under ambient conditions shows the largest inflections at about 60 and $145 \mathrm{ft}$ bls. The fluid-conductivity log collected under ambient and pumping conditions indicates an inflection at about $145 \mathrm{ft}$ bls that likely corresponds to a water-bearing zone. The flow log collected under ambient conditions indicates slight upward flow throughout the borehole starting near a depth of $145 \mathrm{ft}$ bls (table 8). The flow log collected under pumping conditions indicated that the fractures near $145 \mathrm{ft}$ bls may be the most hydraulically active water-bearing zones in the well. The flow measurements are uncertain because the heat-pulse flowmeter was equipped with an 8-in. diverter in a 10-in. diameter borehole, which allows an unquantified amount of flow to bypass the meter, and thus should be interpreted with caution.

The borehole video log, collected by USGS on August 27, 2019, when the water level was $1.2 \mathrm{ft}$ bls, showed numerous horizontal and some vertical fractures throughout the borehole. Possible water-bearing zones were noted for discrete fractures in the range of depths from about 96-113 ft bls. The primary water-bearing fractures indicated by geophysical logs also included those observed at depths of 140.2-144.8 ft. Video-log images for selected fractures or openings in well BK-2698 are shown in figure 13.

\section{BK-2861 (WTWSA Well 11)}

Well BK-2861 is an unused production well (WTWSA well 11) about 1.3 mi north of the former NAWC Warminster base (figs. 1 and 3). Prior to logging by USGS, the pump and plumbing were removed in summer 2019. The well has 10-in. diameter casing to a depth of about $83 \mathrm{ft}$ bls and below that depth is a 10-in. diameter open hole to about 160 $\mathrm{ft}$ bls (table 2). The depth to ambient water level at the time of logging in September 2018 was about $1.9 \mathrm{ft}$ bls. Well BK-2861 was logged previously in the 1990s by USGS (Bird, 1998, p. 14). 
$\boldsymbol{A}$

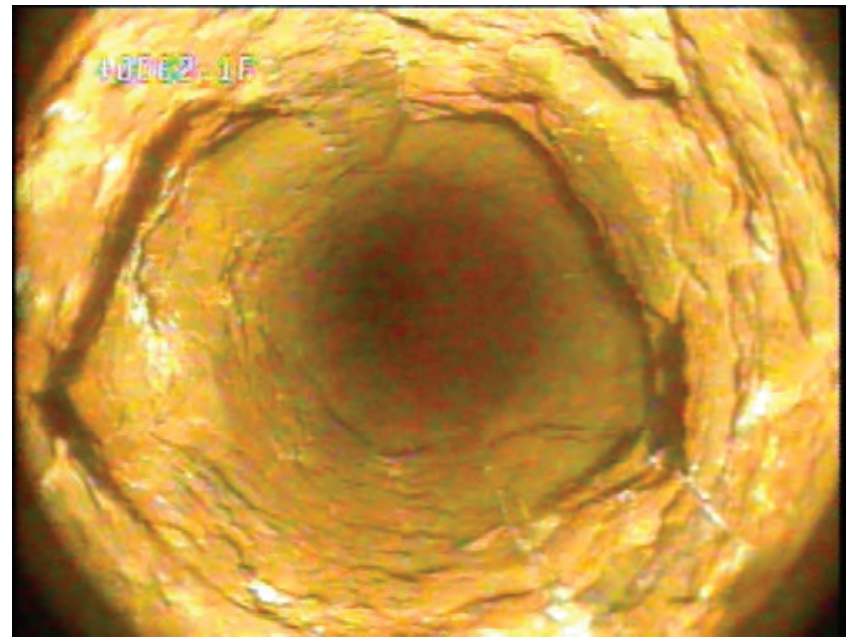

B

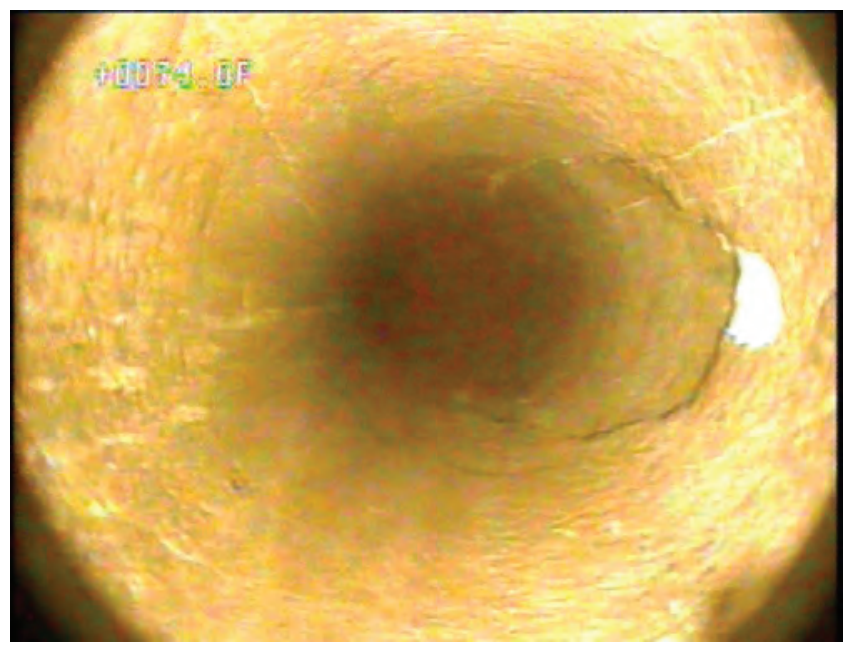

C

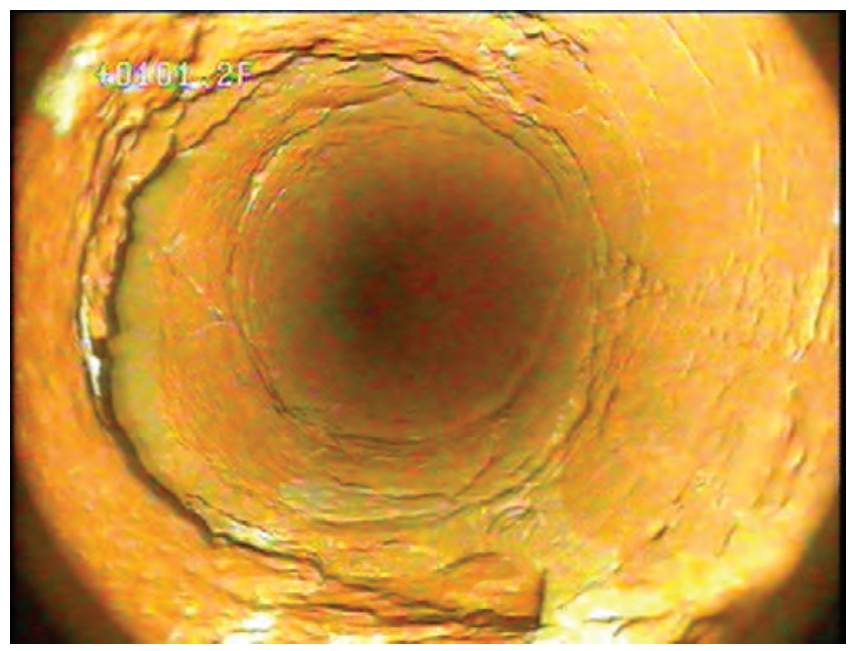

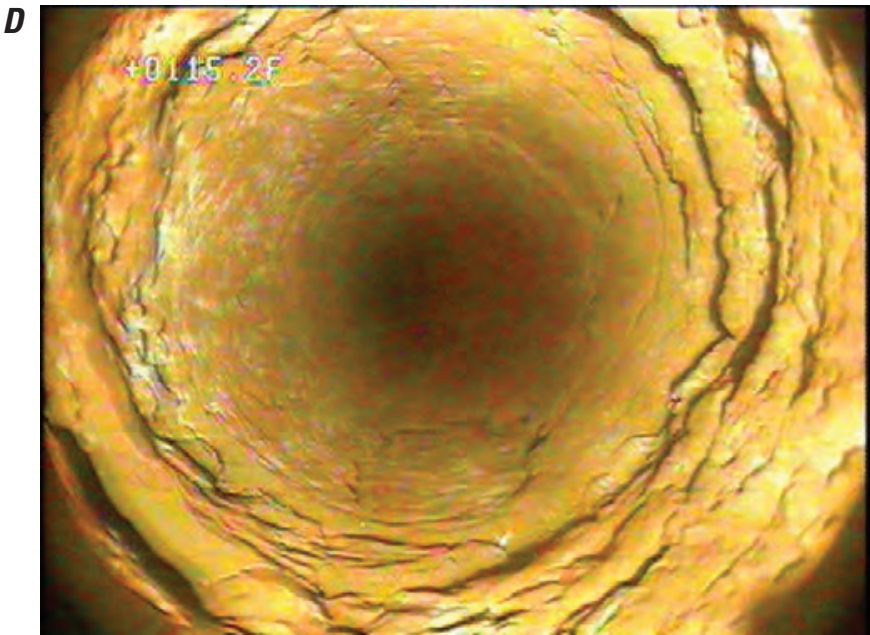

$E$
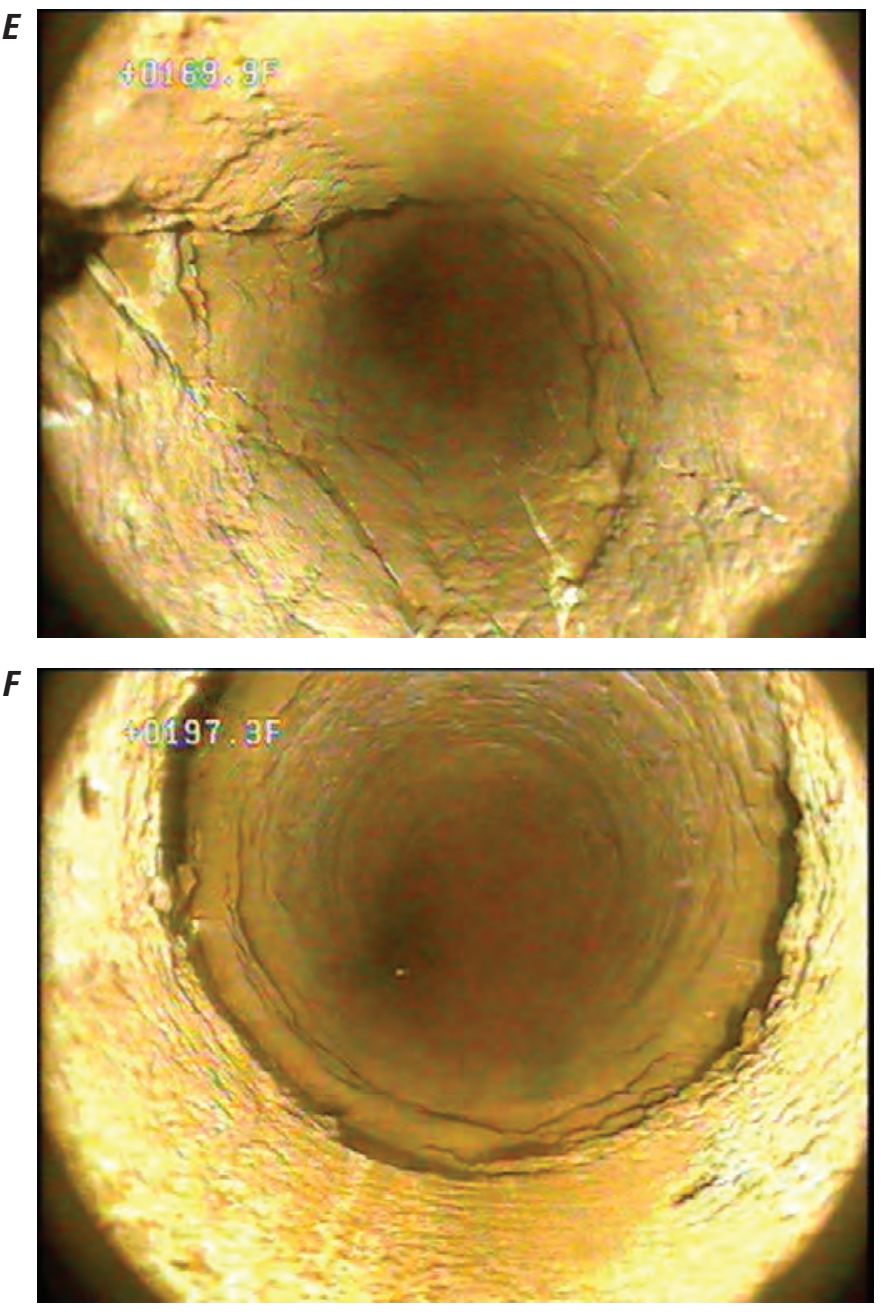

Figure 7. Still images from borehole video log of well BK-1023 (WMA well 28) at $A, 62.1$ feet below land surface (ft bls) showing large openings near bottom of casing, $B, 74.0 \mathrm{ft}$ bls showing high-angle opening, $C, 101.2 \mathrm{feet} \mathrm{ft}$ bls showing possible bedding-plane opening, $D, 115.2 \mathrm{ft}$ bls showing possible bedding-plane openings, $E, 169.4 \mathrm{ft}$ bls showing high-angle fractures, and $F, 197.3 \mathrm{ft}$ showing possible bedding-plane openings. Video log collected by U.S. Geological Survey in well BK-1023, Warminster Township, Bucks County, Pennsylvania, October 3, 2018. 


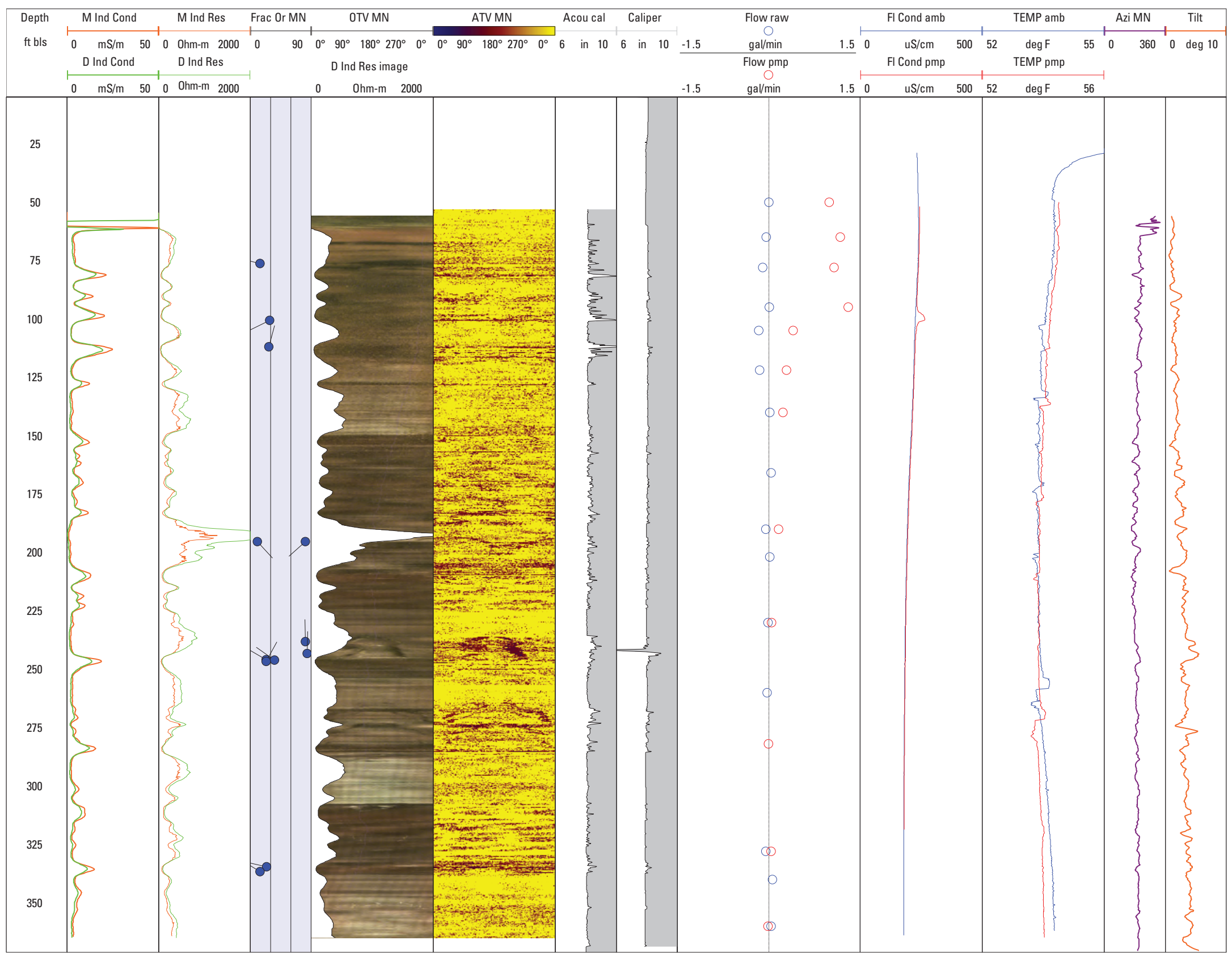

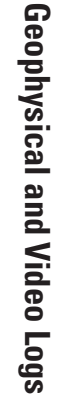

Figure 8. Geophysical logs collected by U.S. Geological Survey in well BK-1087 (WMA well 25), Warminster Township, Bucks County, Pennsylvania, August 10, 2018. See table 1 for explanation of abbreviations. 
Table 6. Borehole flow-measurements collected by U.S. Geological Survey in well BK-1087 (WMA well 25), Ivyland Borough, Bucks County, Pennsylvania, August 10, 2018. Stationary measurements made using an electromagnetic flow meter under ambient and pumping conditions; negative values indicate downward flow and positive values indicate upward flow. Flow values reported in the table reflect corrections to raw measurements based on zero flow in casing under ambient conditions and known flow in casing under pumping conditions.

[ft, feet; bls, below land surface; corr, corrected value; gal/min, gallons per minute; amb, ambient conditions; pmp, pumping conditions; --, no data]

\begin{tabular}{cccc}
\hline \multicolumn{3}{c}{ Ambient conditions } & \\
\hline Depth (ft bls) & $\begin{array}{c}\text { Flow amb1, } \\
\text { corr (gal/min) }\end{array}$ & Depth (ft bls) & $\begin{array}{c}\text { Flow pmp2, corr } \\
\text { (gal/min) }\end{array}$ \\
\hline 50 & 0.00 & 50 & 1.00 \\
65 & -0.04 & 65 & 1.18 \\
78 & -0.10 & 78 & 1.08 \\
95 & 0.01 & 95 & 1.31 \\
105 & -0.16 & 105 & 0.40 \\
122 & -0.15 & 122 & 0.29 \\
140 & 0.02 & 140 & 0.24 \\
166 & 0.04 & 166 & -- \\
190 & -0.05 & 190 & 0.16 \\
202 & 0.02 & 202 & -- \\
230 & -0.01 & 230 & 0.05 \\
260 & -0.02 & 282 & -- \\
282 & -- & 282 & 0.00 \\
328 & -0.05 & 328 & 0.04 \\
340 & 0.06 & 340 & -- \\
360 & 0.04 & 360 & -0.01 \\
\hline
\end{tabular}

1Static water level $=13.39 \mathrm{ft}$ bls.

${ }^{2}$ Pumping rate $=1.0 \mathrm{gal} / \mathrm{min}$; pump on at $10: 02$, stop pump at $11: 22$; drawdown $=1.52 \mathrm{ft}$.

The caliper and ATV logs show several fractures throughout the borehole (fig. 14). Many of the fractures appear to be high angle. The fluid-temperature and fluid-conductivity logs collected under ambient and pumping conditions show no large inflections that could be used to identify depth of water-bearing fractures, although the temperature logs shown differences under ambient and pumping conditions at depths above about $130 \mathrm{ft}$ bls. The flow log collected under ambient conditions indicates slight upward flow throughout the borehole starting near a depth of $144 \mathrm{ft}$ bls, but this flow appears to decrease to less than detection $(<0.001 \mathrm{gal} / \mathrm{min})$ at $110 \mathrm{ft}$ bls (table 9), which may indicate that water exits the borehole through fractures at about $120 \mathrm{ft}$ bls. The flow logs collected under ambient and pumping conditions indicated that the fractures at depths near about 135-140 and 147-152 ft bls may be the most hydraulically active water-bearing zones in the well.
The flow measurements are uncertain because the heat-pulse flowmeter was equipped with an 8-in. diverter in a 10-in. diameter borehole, which allows an unquantified amount of flow to bypass the meter, and thus should be interpreted with caution.

The borehole video log, collected by USGS on August 6, 2019, when the water level was $2.7 \mathrm{ft}$ bls, showed that the well is overbored and out-of-round until about $102 \mathrm{ft}$ bls and that there are several horizontal and vertical fractures throughout the borehole. Possible principal water-bearing zones were noted for fractures at about 136-141 ft bls. Other possible water-bearing fractures indicated by geophysical logs also included those observed at depths of about 86.5, 96-98, 118.5-121, and $149 \mathrm{ft}$ bls. Visibility was poor in the video log of well owing to numerous particles in the water column after the recent removal of the pump from the well. Video-log images for selected fractures or openings in well BK-2861 are shown in figure 15.

\section{BK-2869 (WTWSA Well 9)}

Well BK-2869 is an unused production well (WTWSA well 9) about $1.5 \mathrm{mi}$ north of the former NAWC Warminster base (figs. 1 and 3). Prior to logging by USGS, the pump and plumbing were removed in summer 2019. The well has 12-in. diameter casing to a depth of about $63 \mathrm{ft}$ bls; below that depth is a 12-in. diameter open hole to $85 \mathrm{ft}$ bls and then a 10-in. diameter borehole to about $315 \mathrm{ft}$ bls (table 2). The depth to ambient water level at the time of logging was about $17.9 \mathrm{ft}$ bls.

The caliper and ATV logs show several fractures throughout the borehole (fig. 16). Many of the fractures appear to be low angle. High turbidity in the well at the time of logging reduced visibility needed for the OTV log. The fluidtemperature logs collected under ambient and pumping conditions show similar inflections at about 85 and $220 \mathrm{ft}$ bls that could be used to identify depth of water-bearing fractures. The fluid-conductivity logs collected under ambient and pumping conditions also show similar inflections at about $85 \mathrm{ft}$ bls. The flow log collected under ambient conditions indicates slight downward flow starting near $80 \mathrm{ft}$ bls, but this flow appears to decrease to less than detection $(<0.001 \mathrm{gal} / \mathrm{min})$ at about $243 \mathrm{ft}$ bls (table 10), which may indicate that water exits the borehole through fractures at about 180 to $220 \mathrm{ft}$ bls. The flow log collected under pumping conditions indicated that the fractures at depths above $85 \mathrm{ft}$ bls are the most hydraulically active water-bearing zones in the well. The flow measurements are uncertain because the heat-pulse flowmeter was equipped with an 8-in. diverter in a 10-in. diameter borehole, which allows an unquantified amount of flow to bypass the meter, and thus should be interpreted with caution.

The borehole video log, collected by USGS on July 25, 2019, when the water level was $19.5 \mathrm{ft}$ bls, showed several mostly horizontal and some vertical fractures throughout the borehole. The video shows that the well was overbored and has an irregular shape to a depth of about $85 \mathrm{ft}$ bls. Possible 

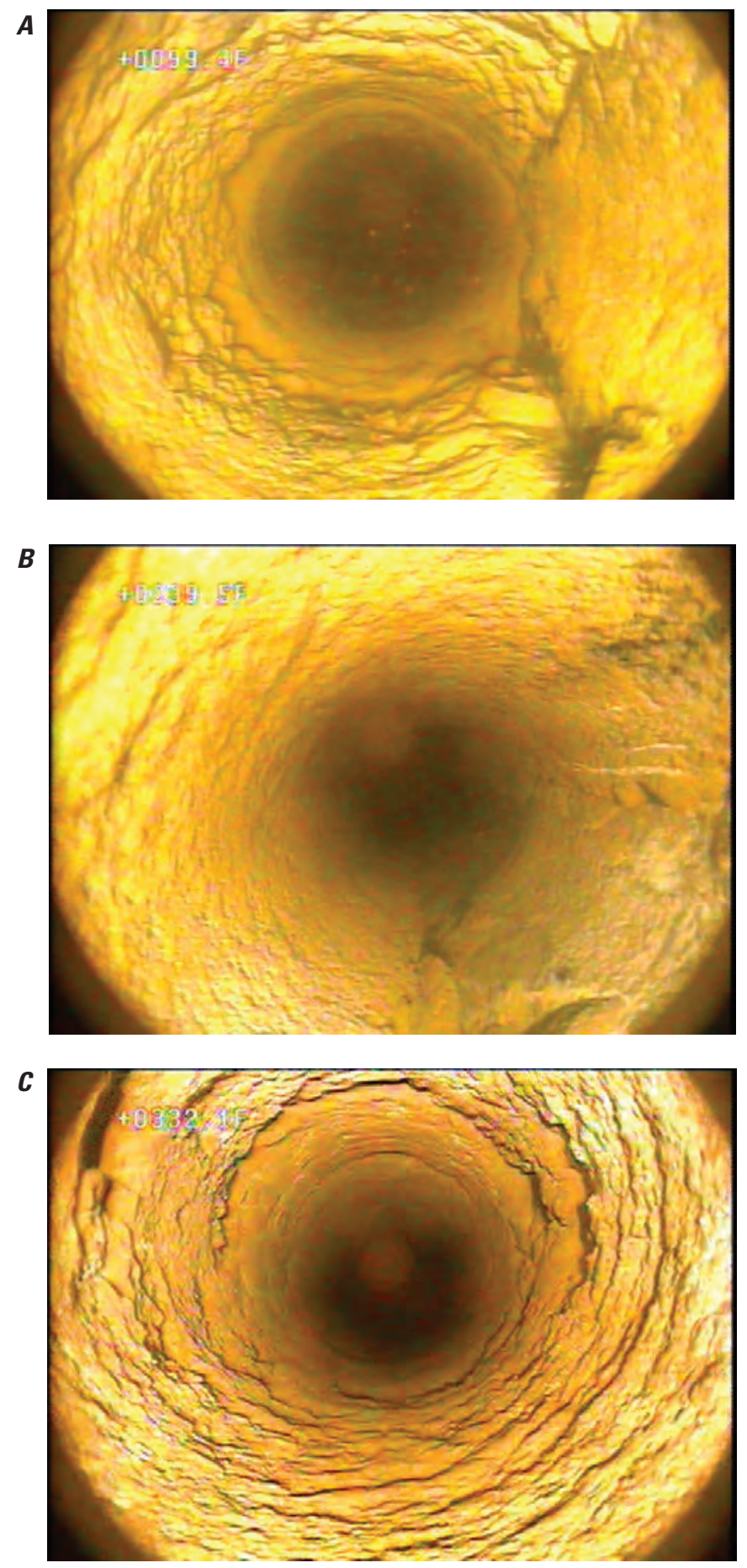

Figure 9. Still images from borehole video log of well BK-1087 (WMA well 25) at $A, 99.4$ feet below land surface (ft bls) showing possible high-angle fracture and bedding-plane opening, $B, 239.5$ $\mathrm{ft}$ bls showing high-angle fracture and reduced visibility, and $C$, $332.1 \mathrm{ft}$ bls showing possible bedding-plane openings and good visibility at depth with upward ambient flow. Video log collected by U.S. Geological Survey in well BK-1087, Ivyland Borough, Bucks County, Pennsylvania, August 29, 2018. water-bearing zones were noted for fractures at about 81.7-95, $155,175,265$ and $280 \mathrm{ft}$ bls. Video-log images for selected fractures or openings in well BK-2869 are shown in figure 17.

\section{BK-2870 (WTWSA Well 10)}

Well BK-2870 is an unused production well (WTWSA well 10) about 1.5 mi north of the former NAWC Warminster base (figs. 1 and 3). Prior to logging by USGS, the pump and plumbing were removed in summer 2019. The well has 10-in. diameter casing to a depth of about $61 \mathrm{ft}$ bls and below that depth is a 10-in. diameter open hole to $270 \mathrm{ft}$ bls (table 2). The depth to ambient water level at the time of logging was about $27.9 \mathrm{ft}$ bls.

The caliper and ATV logs show several fractures throughout the borehole, with the largest openings at about 85, 95, and $118 \mathrm{ft}$ bls that appear to be high angle (fig. 18). The presence of a polyvinyl chloride (PVC) pipe in the well prevented collection of the OTV log because the tool for this log needs to be centralized. The fluid-temperature logs collected under ambient and pumping conditions show inflections at about 65 and $220 \mathrm{ft}$ bls. The fluid-conductivity log collected under ambient conditions shows an inflection at about $118 \mathrm{ft}$ bls, and, under pumping conditions, shows an inflection at about $85 \mathrm{ft}$ bls. The flow $\log$ collected under ambient conditions indicates slight upward flow starting near $256 \mathrm{ft}$ bls, but this flow appears to decrease to less than detection $(<0.001 \mathrm{gal} / \mathrm{min})$, reported as $0.0 \mathrm{gal} / \mathrm{min}$, at about $108 \mathrm{ft}$ bls (table 11), which may indicate that water exits the borehole through fractures at about $118 \mathrm{ft}$ bls but also could be related to bypass around the 8 -in. diverter. The flow measurements are uncertain because the heat-pulse flowmeter was equipped with an 8-in. diverter in a 10 -in. diameter borehole, which allows an unquantified amount of flow to bypass the meter, and thus should be interpreted with caution. The flow log collected under pumping conditions indicated that the fractures at depths above about $85 \mathrm{ft}$ bls are the most hydraulically active water-bearing zones in the well, but fractures at other depths, including near 118,220 and below $256 \mathrm{ft}$ bls also appear to be hydraulically active.

The borehole video log, collected by USGS on August 9, 2019 , when the water level was $24.1 \mathrm{ft}$ bls, was collected only to about $87 \mathrm{ft}$ bls at a depth where potentially loose rocks were observed. The video log showed the top of a 2-in. PVC pipe string at about $63 \mathrm{ft}$ bls, apparently left in the borehole after pump removal. The video log also showed a horizontal fracture at about $67 \mathrm{ft}$ bls and a large vertical fracture starting at $84.7 \mathrm{ft}$ bls. Video-log images for selected fractures or openings in well BK-2870 are shown in figure 19.

\section{BK-3062 (NBCMA Well 15)}

Well BK-3062 is an unused test well (NBCMA well 15 near the northeast edge of the former NAWC Warminster base (figs. 1 and 3). The well has 10-in. diameter casing to a depth 


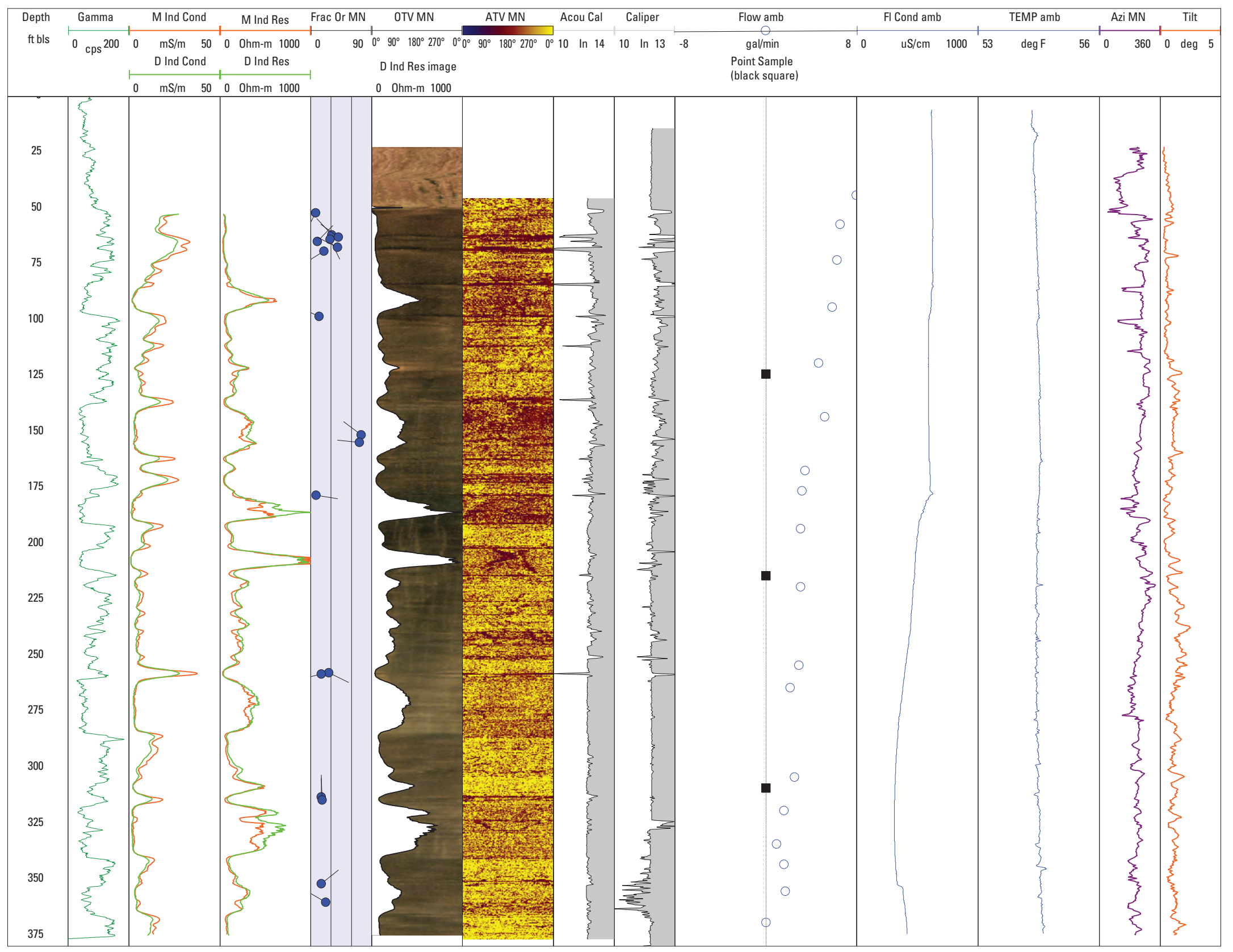

Figure 10. Geophysical logs collected by U.S. Geological Survey in well BK-1129 (WMA well 36), Warminster Township, Bucks County, Pennsylvania, September 5, 2018. See table 1 for explanation of abbreviations. Depth of point samples collected under ambient conditions shown on flow logs. 
Table 7. Borehole flow-measurements collected by U.S. Geological Survey in well BK-1129 (WMA well 36), Warminster Township, Bucks County, Pennsylvania, September 5, 2018. Stationary measurements made using an electromagnetic flow meter under ambient conditions; negative values indicate downward flow and positive values indicate upward flow. Flow measured with 8-inch diameter diverter in 12-inch diameter well that was flowing at about 8 gallons per minute ( $\mathrm{gal} / \mathrm{min}$ ). Reported flow adjusted so that flow in casing at a depth of 45 feet is equal to flow rate of $8 \mathrm{gal} / \mathrm{min}$ at top of casing.

[ft, feet; bls, below land surface; gal/min, gallons per minute; amb, ambient conditions; pmp, pumping conditions; --, no data]

\begin{tabular}{|c|c|}
\hline \multicolumn{2}{|c|}{ Ambient conditions } \\
\hline Depth (ft bls) & Flow amb ${ }^{1}$ (gal/min) \\
\hline 45 & 7.98 \\
\hline 58 & 6.52 \\
\hline 74 & 6.25 \\
\hline 95 & 5.85 \\
\hline 120 & 4.66 \\
\hline 144 & 5.19 \\
\hline 168 & 3.46 \\
\hline 177 & 3.19 \\
\hline 194 & 3.06 \\
\hline 220 & 3.06 \\
\hline 255 & 2.93 \\
\hline 265 & 2.13 \\
\hline 305 & 2.53 \\
\hline 320 & 1.60 \\
\hline 335 & 0.93 \\
\hline 344 & 1.60 \\
\hline 356 & 1.73 \\
\hline 370 & 0.00 \\
\hline
\end{tabular}

1 Well is flowing; flow measured on September 5, 2018, starting at 13:14; flow adjusted to account for measured overflow rate of $8 \mathrm{gal} / \mathrm{min}$ at top of well; all flow is upward.

of about $93 \mathrm{ft}$ bls and below that depth is a 10 -in. diameter open hole to $400 \mathrm{ft}$ bls (table 2). The depth to ambient water level at the time of logging was about $28.8 \mathrm{ft}$ bls.

The caliper and ATV logs show numerous fractures throughout the borehole, with the largest openings at about 100, 120, 160-190 ft bls (fig. 20). Fractures at about 160-175 and 310-324 ft bls appear to be mostly high angle, and fractures at about 95, 120, 135, 185, 230, 240, 285, 305, 370, and $390 \mathrm{ft}$ bls appear to be low angle. The fluid-temperature log collected under ambient conditions show inflections at about 120 and to a small extent, possibly at about $190 \mathrm{ft}$ bls. The fluid-temperature log collected under pumping conditions shows inflections at about 240 and $290 \mathrm{ft}$ bls. The fluid-conductivity logs collected under ambient and pumping conditions show small inflections at about 120 and $130 \mathrm{ft} \mathrm{bls}$. During the collection of the ambient flow log, there appeared to be larger than typical variability in measured values at some depths, and therefore these flow logs should be interpreted with caution. Raw (uncorrected for bypass around diverter and zero flow in casing) ambient flow values are shown in figure 20 and listed in table 12, which also shows estimated flow values for ambient conditions (where estimated values have relatively greater than typical uncertainty) and corrected flow values for pumping conditions. Under ambient conditions, little borehole flow was indicated by the estimated field measurements above $280 \mathrm{ft}$ bls and increasing downward flow below $280 \mathrm{ft}$ bls (table 12). The flow log collected under pumping conditions indicated that the fractures at near depths of about 95 and $185 \mathrm{ft}$ bls appear to be the most hydraulically active water-bearing zones in the well.

The borehole video log, collected by USGS on November 9, 2017, when the water level was $28.2 \mathrm{ft} \mathrm{bls,}$ showed numerous horizontal and vertical fractures throughout the borehole. The number of suspended particles observed in the water column increased below about $300 \mathrm{ft}$ bls, suggesting limited amount of active borehole flow at depths greater than $300 \mathrm{ft}$ bls under ambient conditions at time of logging. Possible principal water-bearing zones were noted for discrete fractures in the range of depths from about 117.6-121, 133, 162.5-174, and 386-389.2 ft bls. Other possible water-bearing fractures indicated by geophysical logs also included those observed at depths of 96.5, 100, 184.5-187, 230.9, 246.3, 289-301, 309-319, and 395-397 ft bls. Video-log images for selected fractures or openings in well BK-3062 are shown in figure 21.

\section{BK-3063 (HN-116)}

Well BK-3063 is a new monitor well (HN-116) drilled by the Navy on the former NAWC Warminster base (figs. 1 and 3) that was logged and subsequently tested by USGS using straddle packers to isolate discrete intervals for hydraulic characterization and sampling in 2018 (Senior and others, 2020) before being reconstructed in 2019. The well was initially constructed with a 6 -in. diameter casing to a depth of about $19 \mathrm{ft}$ bls, and below that depth was a 6-in. diameter open hole to $601 \mathrm{ft}$ bls (table 2). Well BK-3063 is near a cluster of active, relatively shallow (less than $100 \mathrm{ft}$ in depth) extraction wells that are being pumped to address VOC contamination in Areas A and D of the former NAWC Warminster base (fig. 3; Battelle, 2016). Flow logs were collected under ambient and pumping conditions when extraction wells were shut down on May 24, 2018, and under ambient conditions when extraction wells were pumping on May 23, 2018. The depth to ambient water level at the time of logging was about $8.2 \mathrm{ft}$ bls.

The caliper and ATV logs show numerous fractures throughout the borehole, with the largest openings at about 25-50, 170-215, 400-420, 443, 547, and $595 \mathrm{ft}$ bls being mostly high angle (fig. 22). The fluid-temperature log 

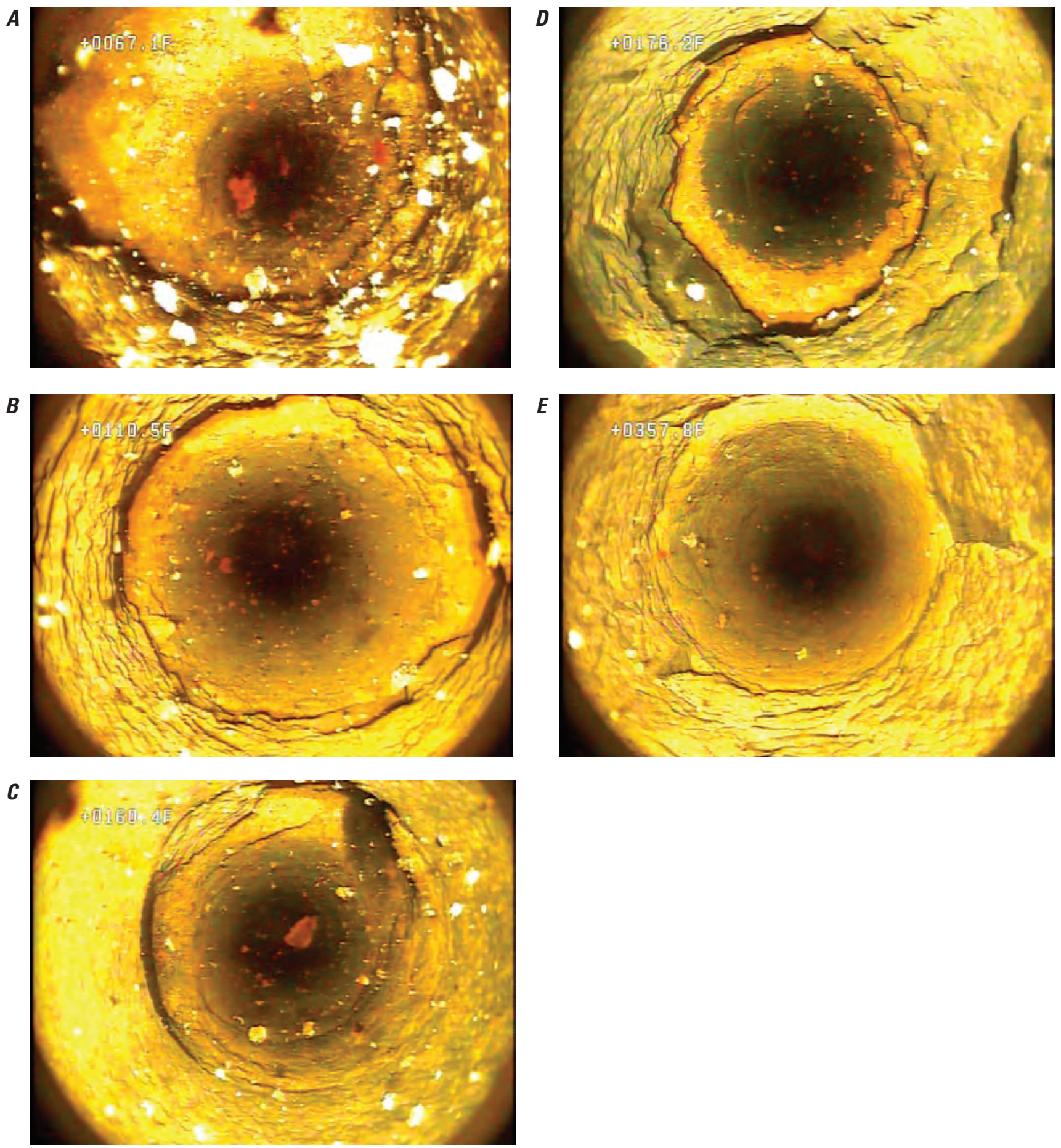

Figure 11. Still images from borehole video log of well BK-1129 (WMA well 36) at $A, 67.1$ feet below land surface (ft bls) showing bedding-plane opening and upward flow of particles, $B, 110.5 \mathrm{ft}$ bls showing bedding-plane opening and upward flow, $C, 160.4$ $\mathrm{ft}$ bls showing bedding-plane opening, $D, 176.2 \mathrm{ft}$ bls showing bedding-plane opening, and $E, 357.8 \mathrm{ft}$ bls showing possible bedding-plane openings and good visibility at depth with upward ambient flow. Video log collected by U.S. Geological Survey in well BK-1129, Warminster Township, Bucks County, Pennsylvania, August 29, 2018. 


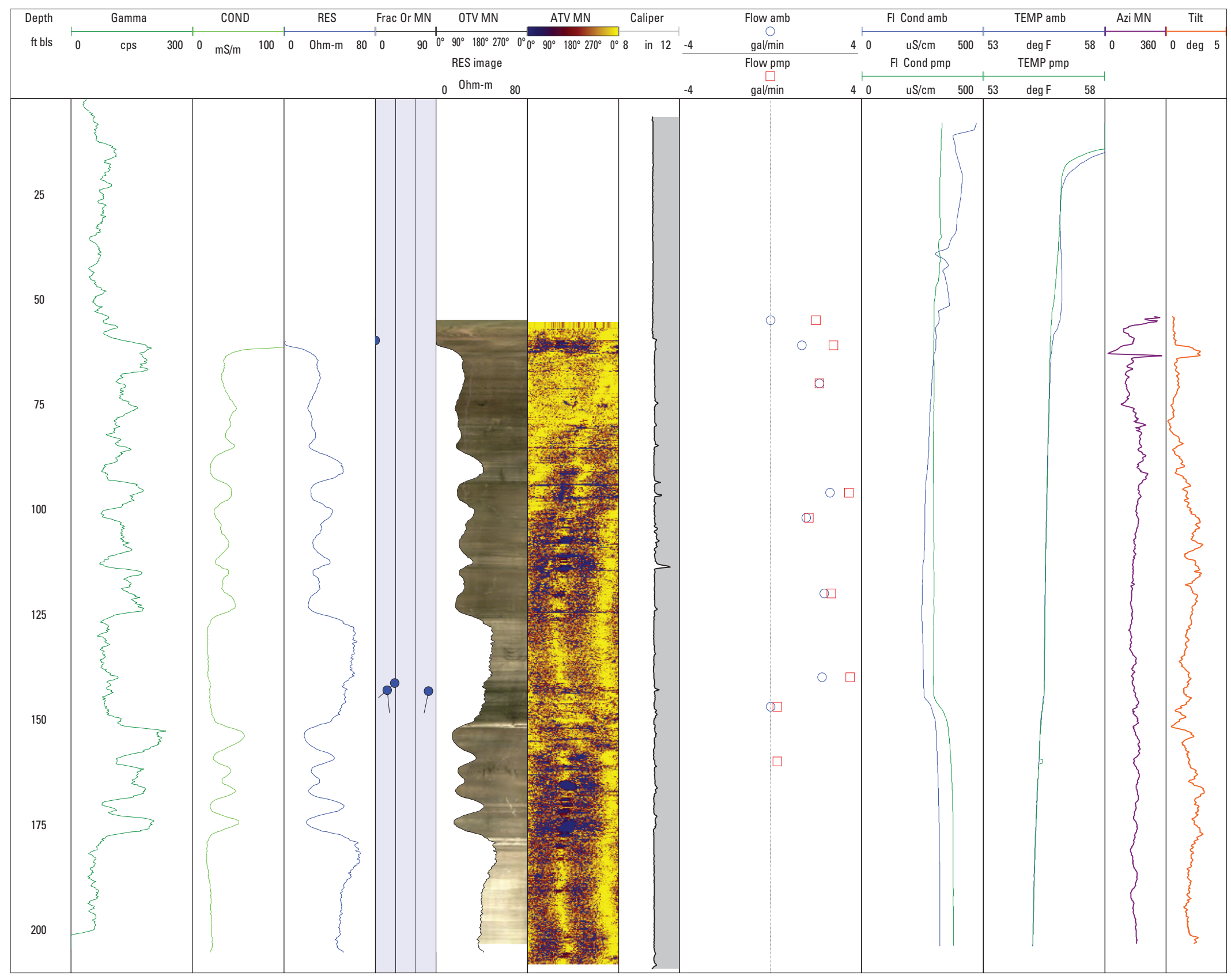

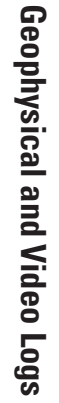

Figure 12. Geophysical logs collected by U.S. Geological Survey in well BK-2698 (WTWSA well 8), Warwick Township, Bucks County, Pennsylvania, September 10, 2019. See table 1 for explanation of abbreviations. 
Table 8. Borehole flow-measurements collected by U.S. Geological Survey in well BK-2698 (WTWSA well 8), Warwick Township, Bucks County, Pennsylvania, September 10, 2019. Stationary measurements made using heat-pulse flow meter under ambient and pumping conditions; negative values indicate downward flow and positive values indicate upward flow. Flow values reported in the table reflect corrections to raw measurements based on zero flow in casing under ambient conditions and known flow in casing under pumping conditions. Flow measured with 8-inch diameter diverter in 10-inch diameter well, which affects accuracy of values as some flow bypasses the diverter.

[ft, feet; bls, below land surface; corr, corrected value; gal/min, gallons per minute; amb, ambient conditions; pmp, pumping conditions; --, no data]

\begin{tabular}{cccc}
\hline \multicolumn{2}{c}{ Ambient conditions } & \multicolumn{2}{c}{ Pumping conditions } \\
\hline Depth (ft bls) & $\begin{array}{c}\text { Flow amb1, } \\
\text { corr (gal/min) }\end{array}$ & $\begin{array}{c}\text { Depth (ft bls) } \\
\text { Flow pmp2, } \\
\text { corr (gal/min) }\end{array}$ \\
\hline 55 & 0.00 & 55 & 2.00 \\
61 & 1.38 & 61 & 2.76 \\
70 & 2.15 & 70 & 2.15 \\
96 & 2.61 & 96 & 3.44 \\
102 & 1.57 & 102 & 1.69 \\
120 & 2.36 & 120 & 2.67 \\
140 & 2.27 & 140 & 3.50 \\
147 & 0.00 & 147 & 0.31 \\
160 & -- & 160 & 0.31 \\
\hline
\end{tabular}

${ }^{1}$ Ambient flow measured starting at 14:58 on September 10, 2019.

2Pumping rate $2.0 \mathrm{gal} / \mathrm{min}$; static water level is $1.20 \mathrm{ft}$ bls at $15: 22$ prior to start of pumping; flow rate measured starting at 15:27; drawdown $0.81 \mathrm{ft}$.

collected under ambient conditions shows inflections at about 35 and $400 \mathrm{ft}$ bls that could be used to identify depth of water-bearing fractures. The fluid-temperature log collected under pumping conditions also shows an inflection at about $400 \mathrm{ft}$ bls. The fluid-conductivity logs collected under ambient and pumping conditions show similar inflections at about 400,425 , and $440 \mathrm{ft}$ bls. The flow log collected under ambient conditions when nearby extraction wells were shutdown indicates upward flow at depths above $181 \mathrm{ft} \mathrm{bls,} \mathrm{with} \mathrm{upward}$ flow decreasing substantially between depths of 47 and 38 $\mathrm{ft}$ bls, and downward flow below depths of $207 \mathrm{ft}$ bls, with downward flow increasing substantially below depth of 395 $\mathrm{ft}$ bls (table 13). This pattern indicates that water enters the borehole through the fractures near $200 \mathrm{ft}$ bls and flows up to exit fractures between 47 and $38 \mathrm{ft}$ bls; water also enters the borehole through fractures near 200, 400, and $430 \mathrm{ft}$ bls and flows down to exit fractures near the bottom of the borehole. The flow log collected under ambient conditions when nearby extraction wells were pumping shows a similar pattern but with generally larger upward flow rates when compared to the ambient flow log collected when extraction wells were
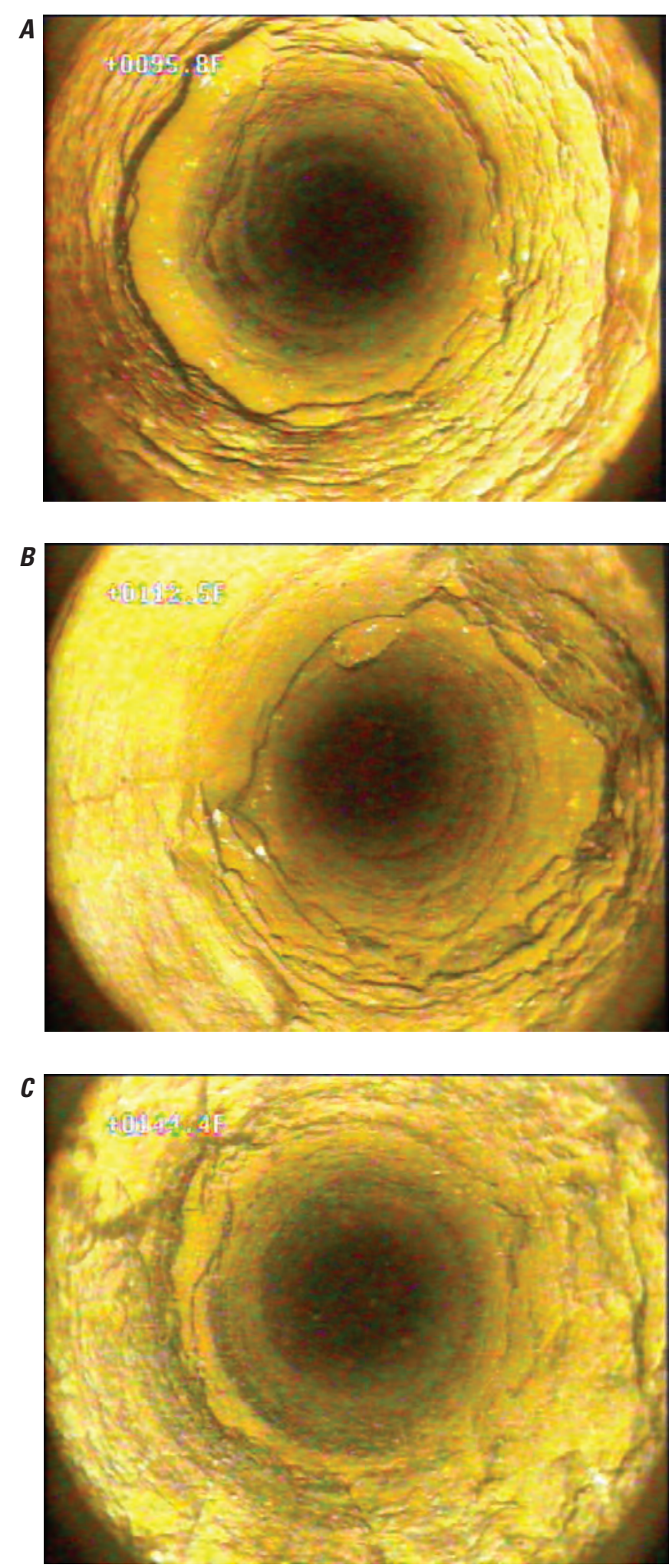

Figure 13. Still images from borehole video log of well BK-2698 (WTWSA well 8) at $A, 95.8$ feet below land surface (ft bls) showing possible bedding-plane opening, $B, 112.8 \mathrm{ft}$ bls showing possible bedding-plane opening, and $C, 144.5 \mathrm{ft}$ bls showing possible bedding-plane openings. Video log collected by U.S. Geological Survey in well BK-2698, Warwick Township, Bucks County, Pennsylvania, August 27, 2019. 


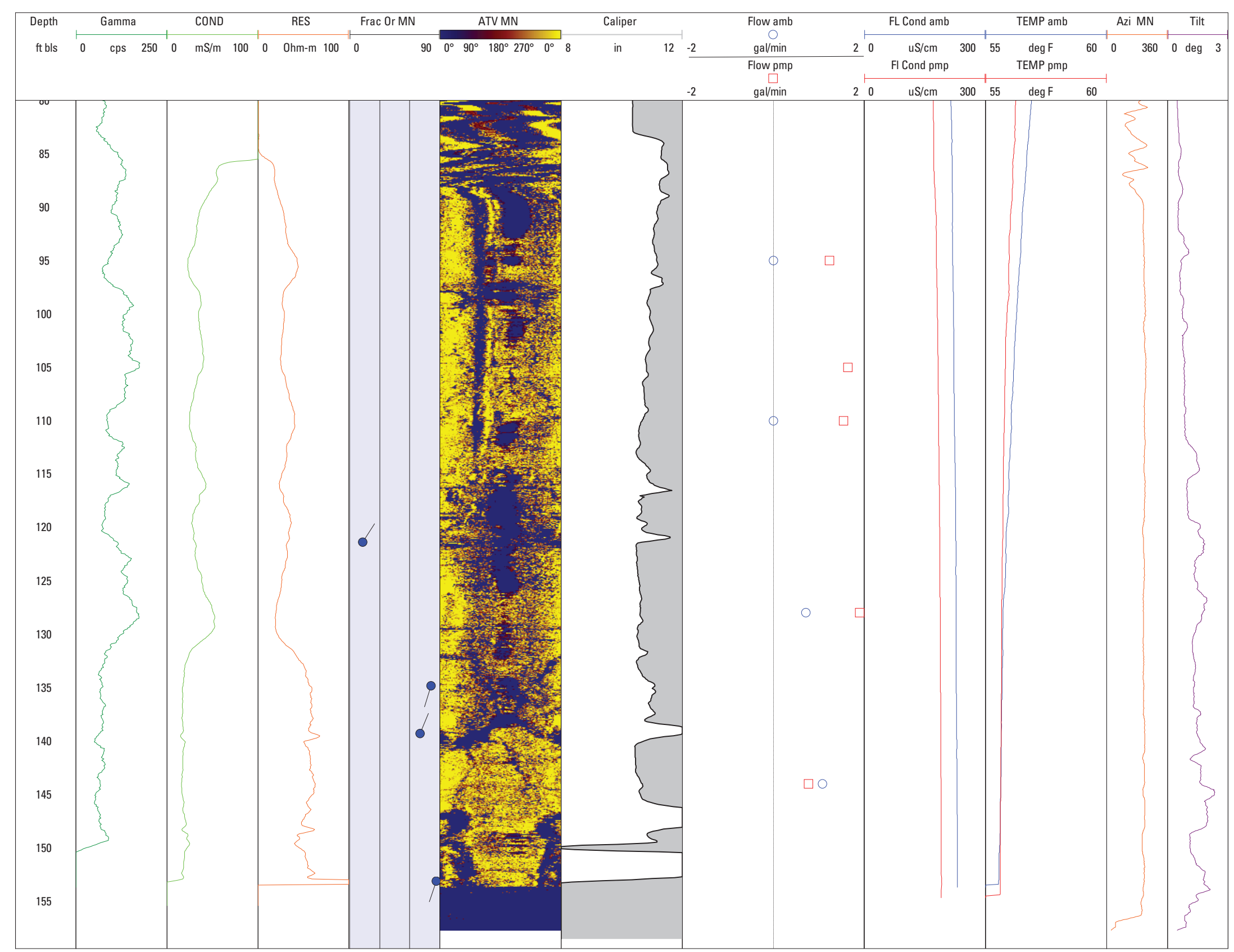

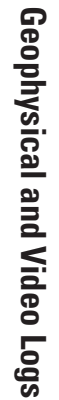

Figure 14. Geophysical logs collected by U.S. Geological Survey in well BK-2861 (WTWSA well 11), Warwick Township, Bucks County, Pennsylvania, September 12, 2019. See table 1 for explanation of abbreviations. 
Table 9. Borehole flow-measurements collected by U.S. Geological Survey in well BK-2861 (WTWSA well 11), Warwick Township, Bucks County, Pennsylvania, September 12, 2019. Stationary measurements made using heat-pulse flow meter under ambient and pumping conditions; negative values indicate downward flow and positive values indicate upward flow. Flow values reported in the table reflect corrections to raw measurements based on zero flow in casing under ambient conditions and known flow in casing under pumping conditions. Flow measured with 8-inch diameter diverter in 10-inch diameter well, which affects accuracy of values as some flow bypasses diverter.

[ft, feet; bls, below land surface; corr, corrected value; gal/min, gallons per minute; amb, ambient conditions; pmp, pumping conditions; --, no data]

\begin{tabular}{cccc}
\hline \multicolumn{2}{c}{ Ambient conditions } & \multicolumn{2}{c}{ Pumping conditions } \\
\hline Depth (ft bls) & $\begin{array}{c}\text { Flow amb1, corr } \\
\text { (gal/min) }\end{array}$ & $\begin{array}{c}\text { Flow pmp2, corr } \\
\text { (gal/min) }\end{array}$ \\
\hline 70 & -- & 70 & 1.70 \\
95 & 0.00 & 95 & 1.24 \\
105 & -- & 105 & 1.65 \\
110 & 0.00 & 110 & 1.55 \\
128 & 0.72 & 128 & 1.91 \\
144 & 1.08 & 144 & 0.77 \\
\hline
\end{tabular}

${ }^{1}$ Static water level $1.9 \mathrm{ft}$ bls on September 12, 2019.

2Pumping rate $1.7 \mathrm{gal} / \mathrm{min}$; drawdown $0.51 \mathrm{ft}$.

shutdown, indicating nearby pumping enhances upward flow above $200 \mathrm{ft}$ bls. The flow log collected under pumping conditions when nearby extraction wells were shutdown indicated that the fractures near $200 \mathrm{ft}$ bls and above $47 \mathrm{ft}$ bls are among the most hydraulically active water-bearing zones in the upper part of the borehole; fractures near 400, 430, and 590-595 $\mathrm{ft}$ bls are among the most hydraulically active water-bearing zones in the lower part of the borehole.

The borehole video log, collected by USGS on May 21, 2018, when the water level was $9.4 \mathrm{ft}$ bls, showed numerous vertical and some horizontal fractures throughout the borehole. Probable water-bearing zones were noted for fractures at about 20.5, 33-35, 40-45, 105.8-114, 170-178.5, 181.6-213, 398-420, 433-441, 452.7, 474.8, 540-544.7, 563.5, and 588-597 ft bls. Turbulence was observed near fractures at about 40-45 and 181.6-213 ft bls. Video-log images for selected fractures or openings in well BK-3063 are shown in figure 23 .

\section{BK-3066 (HN-118)}

Well BK-3066 is a new monitor well (HN-118) drilled by the Navy on the former NAWC Warminster base (figs. 1 and 3) that was logged and subsequently tested by USGS using straddle packers to isolate discrete intervals for hydraulic characterization and sampling in 2018 (Senior and others, 2020)
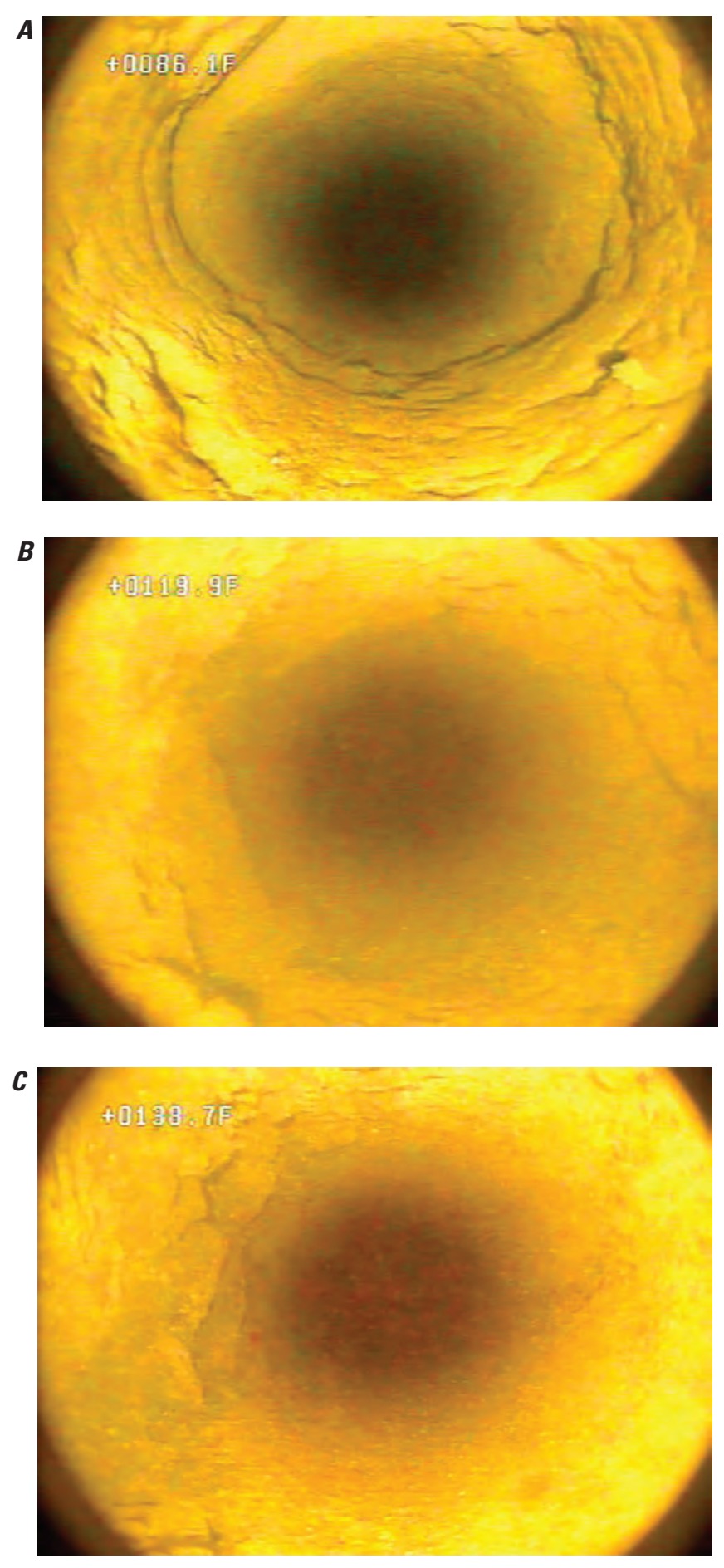

Figure 15. Still images from borehole video log of well BK-2861 (WTWSA well 11) at $A, 86.1$ feet below land surface (ft bls) showing possible bedding-plane opening out-of-round hole owing to overboring, $B, 119.9 \mathrm{ft}$ bls showing water-bearing openings obscured by poor visibility related to suspended particulates, and $C, 138.7 \mathrm{ft}$ bls showing possible water-bearing openings obscured by poor visibility related to suspended particulates. Video log collected by U.S. Geological Survey in well BK-2861, Warwick Township, Bucks County, Pennsylvania, August 6, 2019. 


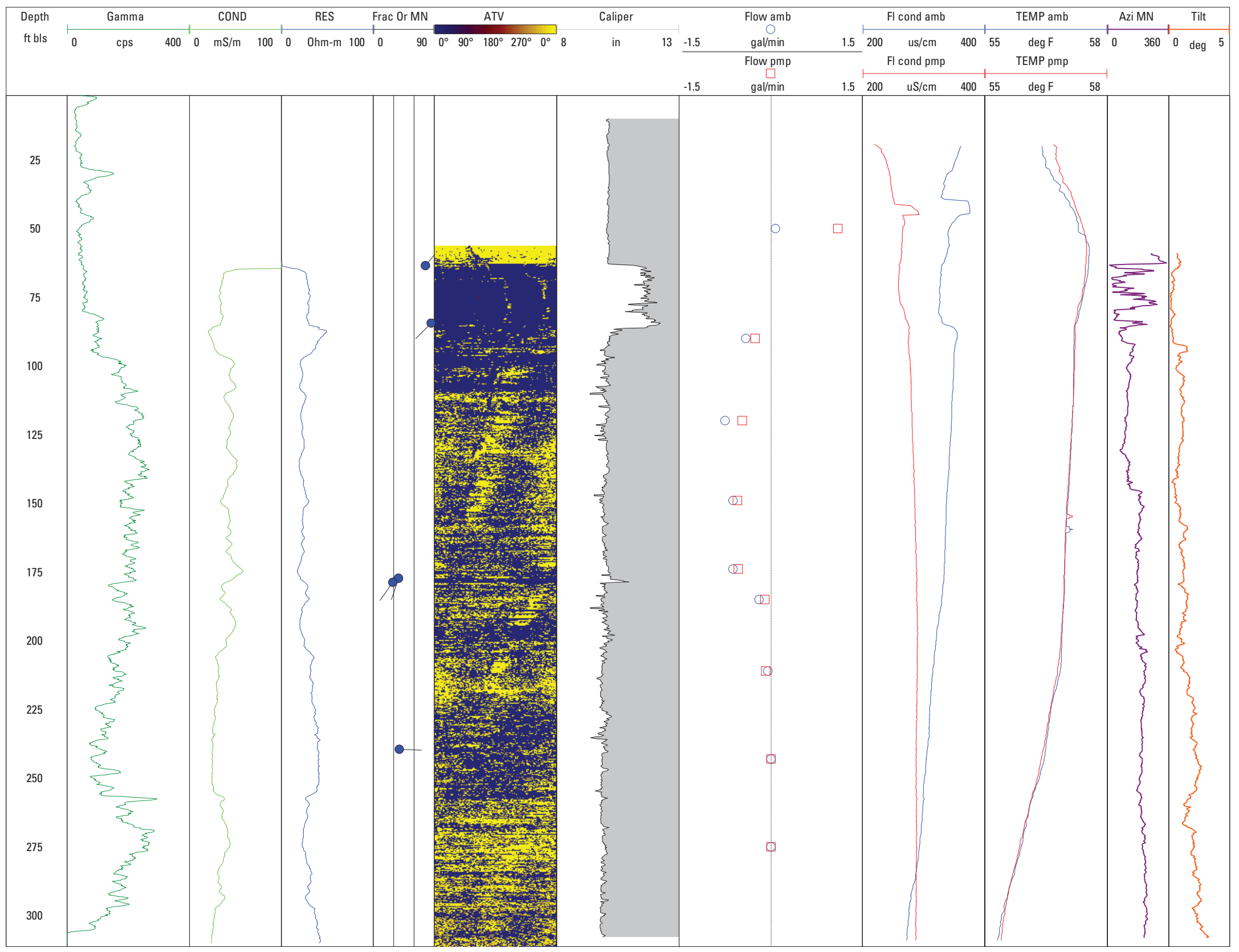

Figure 16. Geophysical logs collected by U.S. Geological Survey in well BK-2869 (WTWSA well 9), Warwick Township, Bucks County, Pennsylvania, June 16-17, 2019. See table 1 for explanation of abbreviations. 
Table 10. Borehole flow-measurements collected by U.S. Geological Survey in well BK-2869 (WTWSA well 9), Warwick Township, Bucks County, Pennsylvania, June 16-17, 2019. Stationary measurements made using heat-pulse flow meter under ambient and pumping conditions; negative values indicate downward flow and positive values indicate upward flow. Flow values reported in the table reflect corrections to raw measurements based on zero flow in casing under ambient conditions and known flow in casing under pumping conditions. Flow measured with 8-inch diameter diverter in 10-inch diameter well, which affects accuracy of values as some flow bypasses diverter.

[ft, feet; bls, below land surface; corr, corrected value; gal/min, gallons per minute; amb, ambient conditions; pmp, pumping conditions; --, no data]

\begin{tabular}{cccc}
\hline \multicolumn{2}{c}{ Ambient conditions } & \multicolumn{2}{c}{ Pumping conditions } \\
\hline Depth (ft bls) & $\begin{array}{c}\text { Flow amb1, corr } \\
\text { (gal/min) }\end{array}$ & Depth (ft bls) & $\begin{array}{c}\text { Flow pmp2, corr } \\
\text { (gal/min) }\end{array}$ \\
\hline 50 & 0.08 & 50 & 1.10 \\
90 & -0.41 & 90 & -0.25 \\
120 & -0.75 & 120 & -0.46 \\
149 & -0.62 & 149 & -0.55 \\
174 & -0.62 & 174 & -0.53 \\
185 & -0.19 & 185 & -0.10 \\
211 & -0.05 & 211 & -0.08 \\
243 & 0.00 & 243 & 0.00 \\
275 & 0.00 & 275 & 0.00 \\
\hline
\end{tabular}

${ }^{1}$ Ambient flow measured starting at 11:32 on September 12, 2019.

2Pumping rate $1.1 \mathrm{gal} / \mathrm{min}$; static water level is $20.0 \mathrm{ft}$ bls at 13:22 prior to start of pumping; flow rate measured starting at 14:01; drawdown $1.02 \mathrm{ft}$.

before being reconstructed in 2019. The well was initially constructed with a 6-in. diameter casing to a depth of about $19 \mathrm{ft}$ bls and below that depth was a 6-in. diameter open hole to 602 $\mathrm{ft}$ bls (table 2). The depth to ambient water level at the time of logging was not stable, suggesting the possible influence of nearby pumping. The measured depth to water level was 30.82 $\mathrm{ft}$ bls at 10:32 and 29.30 ft bls at 13:36 on August 7, 2018.

Cascading water from fractures above ambient water level was heard and noted at the time of logging, conditions that could potentially affect accuracy of water levels measurements, although field notes do not indicate problems with water-level measurements.

The caliper and ATV logs show numerous fractures throughout the borehole, with the largest openings at depths ranging from 19 to about $100 \mathrm{ft}$ bls (fig. 24). Most fractures are low angle except for fractures near 100 and $540 \mathrm{ft}$ bls that are high angle. The fluid-temperature logs collected under ambient and pumping conditions show inflections at about 100 and $590 \mathrm{ft}$ bls that help identify depth of water-bearing fractures. The fluid-temperature log collected under ambient conditions also shows an inflection at about $80 \mathrm{ft}$ bls. The
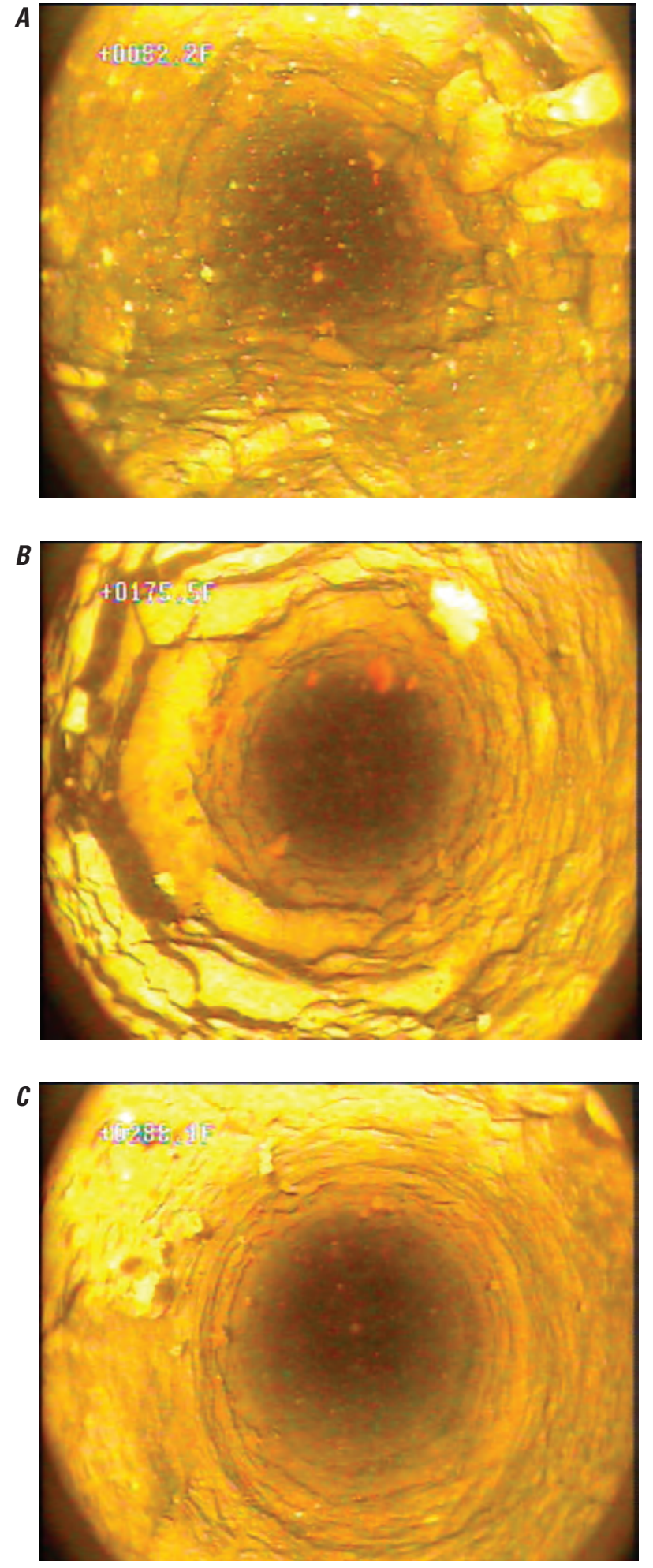

Figure 17. Still images from borehole video log of well BK-2869 (WTWSA well 9) at $A, 82.2$ feet below land surface (ft bls) showing high-angle fractures and out-of-round hole due to overboring, $B, 175.5 \mathrm{ft}$ bls showing bedding-plane opening, and $C, 288.1 \mathrm{ft}$ showing possible bedding-plane opening. Video log collected by U.S. Geological Survey in well BK-2869, Warwick Township, Bucks County, Pennsylvania, July 25, 2019. 


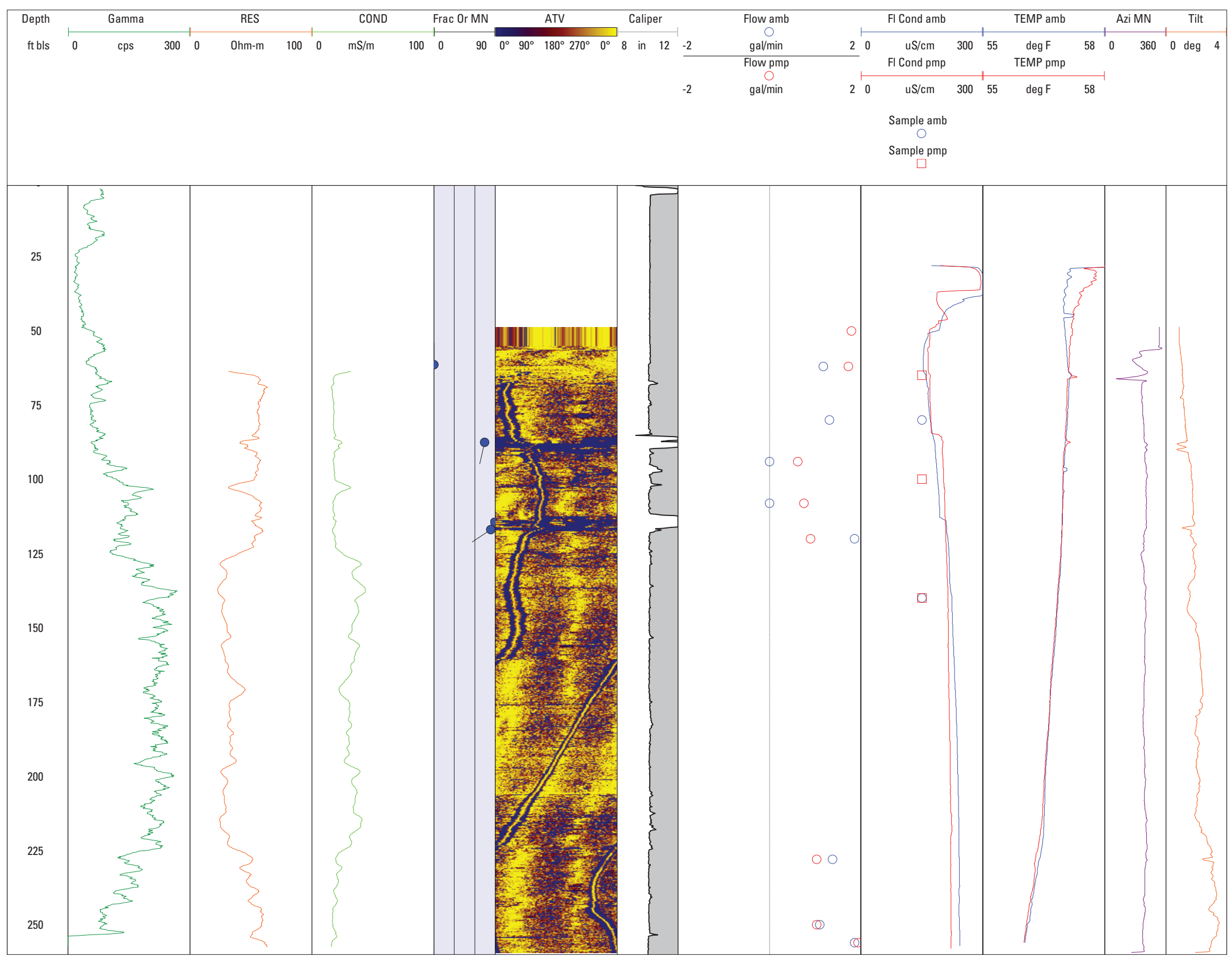

Figure 18. Geophysical logs collected by U.S. Geological Survey in well BK-2870 (WTWSA well 10), Warwick Township, Bucks County, Pennsylvania, September 11, 2019. See table 1 for explanation of abbreviations. Depth of point samples collected under ambient and pumping conditions shown on fluid conductivity logs. 
Table 11. Borehole flow-measurements collected by U.S. Geological Survey in well BK-2870 (WTWSA well 10), Warwick Township, Bucks County, Pennsylvania, September 11, 2019. Stationary measurements made using heat-pulse flow meter under ambient and pumping conditions; negative values indicate downward flow and positive values indicate upward flow. Flow values reported in the table reflect corrections to raw measurements based on zero flow in casing under ambient conditions and known flow in casing under pumping conditions. Flow measured with 8-inch diameter diverter in 10-inch diameter well, which affects accuracy of values as some flow bypasses diverter.

[ft, feet; bls, below land surface; corr, corrected value; gal/min, gallons per minute; amb, ambient conditions; pmp, pumping conditions; --, no data]

\begin{tabular}{cccc}
\hline \multicolumn{2}{c}{ Ambient conditions } & \multicolumn{2}{c}{ Pumping conditions } \\
\hline Depth (ft bls) & $\begin{array}{c}\text { Flow amb1, corr } \\
\text { (gal/min) }\end{array}$ & Depth (ft bls) & $\begin{array}{c}\text { Flow pmp2, corr } \\
\text { (gal/min) }\end{array}$ \\
\hline 62 & 1.18 & 50 & 1.80 \\
80 & 1.31 & 62 & 1.73 \\
94 & 0.00 & 94 & 0.62 \\
108 & 0.00 & 108 & 0.76 \\
120 & 1.87 & 120 & 0.90 \\
228 & 1.38 & 228 & 1.04 \\
250 & 1.11 & 250 & 1.04 \\
256 & 1.87 & 256 & 1.94 \\
\hline
\end{tabular}

1Ambient flow measured starting at 11:51 on September 11, 2019.

2Pumping rate $1.8 \mathrm{gal} / \mathrm{min}$; static water level is $29.38 \mathrm{ft}$ bls at $16: 17$ prior to start of pumping; flow rate measured starting at 15:46; drawdown $0.32 \mathrm{ft}$.

fluid-conductivity logs collected under ambient and pumping conditions both show small inflections at about 100 and $150 \mathrm{ft}$ bls.

The flow log collected under ambient conditions indicates downward flow at depths below $35 \mathrm{ft}$ bls, with downward flow increasing substantially between depths of 35 and 39 $\mathrm{ft}$ bls, then decreasing substantially between depths of 530 and $550 \mathrm{ft}$ bls, and decreasing again between depths of 565 and 574 and also between 574 and $595 \mathrm{ft}$ bls (table 14). This pattern indicates that water enters the borehole through the fractures near 19 to $39 \mathrm{ft}$ bls and flows down to exit fractures near 540,570 , and $590 \mathrm{ft}$ bls under ambient conditions at the time of logging. The flow log collected under pumping conditions indicated that the fractures between 35 and $39 \mathrm{ft}$ bls are the most hydraulically active water-bearing zones in the well. Downward flow rates were greater when measured under pumping conditions than under ambient conditions, suggesting changes in aquifer conditions possibly related to changes in nearby pumping. Measured depth to water levels during pumping at a constant rate was unstable and does not reflect a typical drawdown pattern; levels rose from $30.45 \mathrm{ft}$ bls at 14:15 (after 10 minutes of pumping) to $29.46 \mathrm{ft}$ bls at
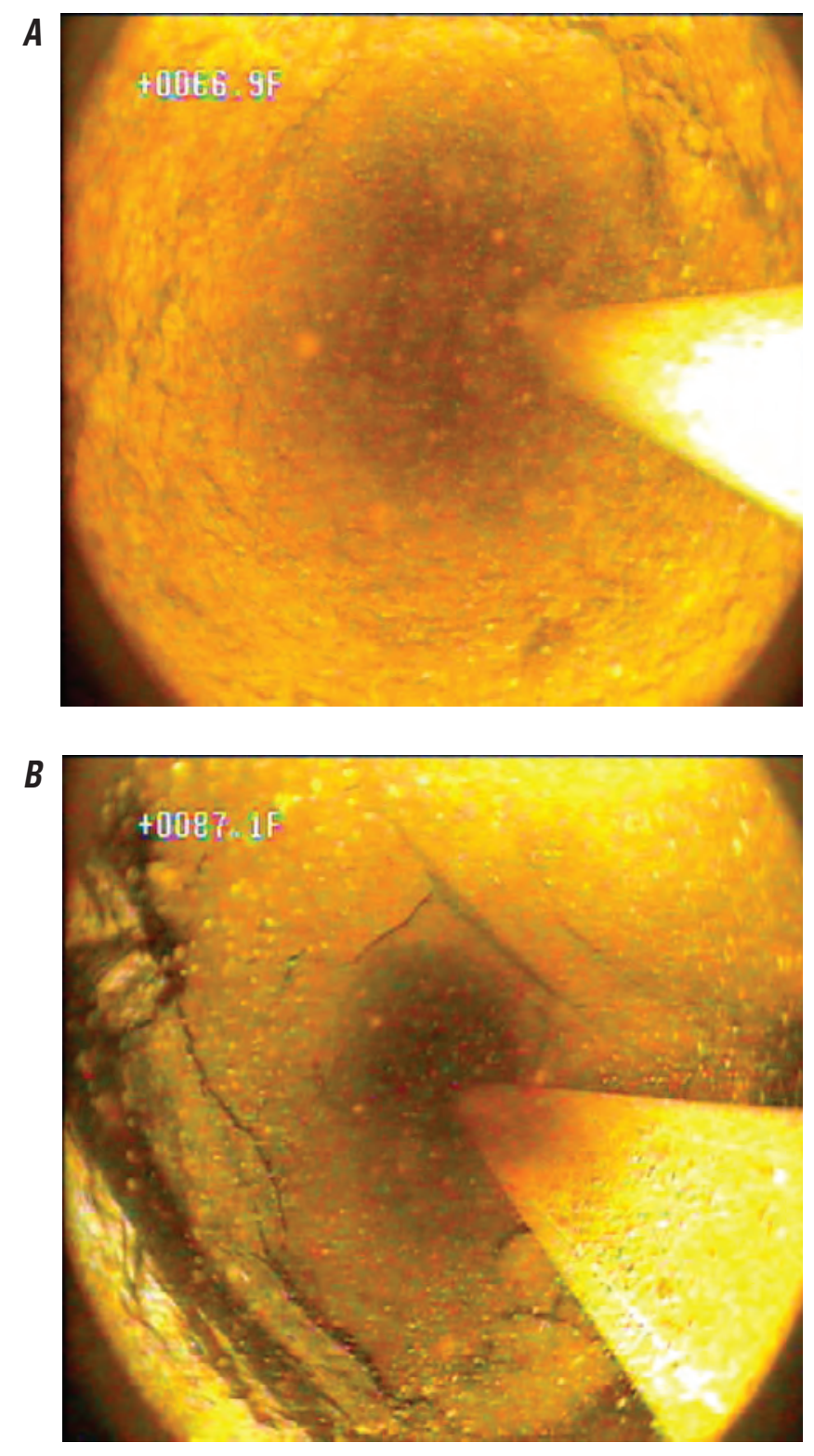

Figure 19. Still images from borehole video log of well BK-2870 (WTWSA well 10) at $A, 66.9$ feet below land surface ( $\mathrm{ft}$ bls) showing low-angle opening and $B, 87.1$ $\mathrm{ft}$ bls showing vertical fracture and top of plastic pipe left in borehole. Video log collected by U.S. Geological Survey in well BK-2870, Warwick Township, Bucks County, Pennsylvania, August 9, 2019.

15:17 (after 72 minutes of pumping), then declined slightly to $29.70 \mathrm{ft}$ bls at 15:28 (after 83 minutes of pumping) (table 14). An active 600 -ft-deep production well is close enough (about $2,150 \mathrm{ft}$ slightly down dip) to potentially affect aquifer conditions in the vicinity of well BK-3066.

The borehole video log, collected by USGS on August 2, 2018 , when the water level was $32.9 \mathrm{ft}$ bls, showed numerous horizontal and some vertical fractures throughout the 


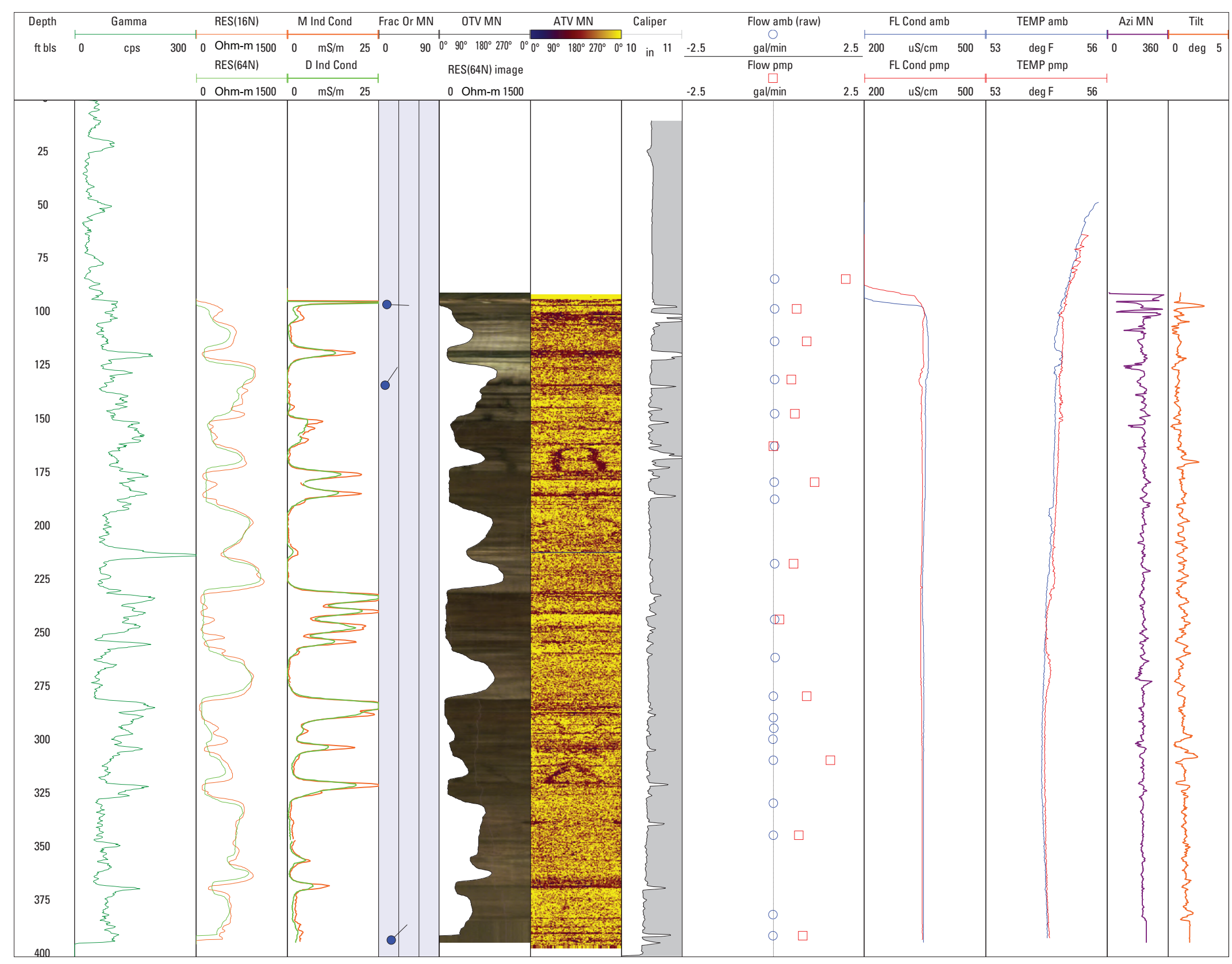

Figure 20. Geophysical logs collected by U.S. Geological Survey in well BK-3062 (NBCMA well 15), Northampton Township, Bucks County, Pennsylvania, November 28-29, 2017. See table 1 for explanation of abbreviations. Ambient flow values are raw uncorrected values; see table 12 for adjusted ambient flow values. 
Table 12. Borehole flow-measurements collected by U.S. Geological Survey in well BK-3062 (NBCMA well 15), Northampton Township, Bucks County, Pennsylvania, November 28-29, 2017. Stationary measurements made using an electromagnetic flow meter under ambient and pumping conditions; negative values indicate downward flow and positive values indicate upward flow. Flow values reported in the table reflect corrections to raw measurements based on zero flow in casing under ambient conditions and known flow in casing under pumping conditions. Flow measured with 8-inch diameter diverter in 10-inch diameter well, which affects accuracy of values as some flow bypasses diverter.

[ft, feet; bls, below land surface; est, estimated value; corr, corrected value; gal/min, gallons per minute; amb, ambient conditions; pmp, pumping conditions; --, no data]

\begin{tabular}{ccccc}
\hline & \multicolumn{2}{c}{ Ambient conditions } & \multicolumn{2}{c}{ Pumping conditions } \\
\hline Depth (ft bls) & Flow amb1, raw (gal/min) & Flow amb2, est (gal/min) & Depth (ft bls) & Flow pmp3, corr (gal/min) \\
\hline 85 & 0.05 & 0.00 & 85 & 2.00 \\
99 & 0.05 & 0.02 & 99 & 0.65 \\
114 & 0.04 & -0.15 & 114 & 0.92 \\
132 & 0.04 & -0.11 & 132 & 0.49 \\
148 & 0.05 & 0.00 & 148 & 0.60 \\
163 & 0.05 & 0.00 & 163 & 0.00 \\
180 & 0.04 & -0.26 & 180 & 1.14 \\
188 & 0.04 & -0.09 & 188 & -- \\
218 & 0.05 & -0.02 & 218 & 0.56 \\
244 & 0.04 & -0.06 & 244 & 0.17 \\
262 & 0.06 & 0.17 & 262 & -- \\
280 & 0.01 & -0.84 & 280 & 0.92 \\
290 & 0.01 & -0.75 & 290 & -- \\
295 & 0.02 & -0.56 & 295 & - \\
300 & 0.00 & -1.05 & 300 & -- \\
310 & 0.00 & -1.01 & 310 & 1.57 \\
330 & 0.00 & -1.01 & 330 & -- \\
345 & 0.00 & -1.01 & 345 & 0.71 \\
382 & -0.01 & -1.16 & 382 & -- \\
392 & 0.00 & -1.10 & 392 & 0.82 \\
\hline
\end{tabular}

${ }^{1}$ Ambient water level $=30.49 \mathrm{ft}$ bls when flow measurements started at 8:57 on November 29, 2017;

2Owing to larger than usual uncertainty in measurements indicated by variability in observed raw values at given depths, estimated flow may be inaccurate where estimated flow represents raw values that were adjusted based on zero flow in casing under ambient conditions and known upward flow of 2 gal/min under pumping conditions.

3Pumping rate $=2.0 \mathrm{gal} / \mathrm{min}$; start pump at 11:24, end pump at 12:34; drawdown $=2.25 \mathrm{ft}$; flow corrected using same adjustment factors used to compute estimated values under ambient conditions

borehole. Water was observed cascading into the borehole at a depth of about $23 \mathrm{ft}$ bls, above the ambient water level. Probable water-bearing zones were noted for fractures at about $23,37,99-104,152.7,318,323,479.8,512.5,525-540$, and $568.2 \mathrm{ft}$ bls. Other possible water-bearing fractures were noted near $60.8,80.1,201.9,251.1,290.2,294.6,299,310.5,337.6$, $438.4-445,483.3,519.8,549$, and $573.3 \mathrm{ft}$ bls. In addition, possible water-bearing fractures indicated by geophysical logs also included those observed at depths of 587.9-590 ft bls. Turbulence was observed near fractures at about 152.7, 201.9, and $568.2 \mathrm{ft}$ bls. Video-log images for selected fractures or openings in well BK-3063 are shown in figure 25.

\section{BK-3067 (HN-119)}

Well BK-3067 is a new monitor well (HN-119) drilled by the Navy on the former NAWC Warminster base (figs. 1 and 3 ) that was logged and subsequently tested by USGS using straddle packers to isolate discrete intervals for hydraulic characterization and sampling in 2018 (Senior and others, 2020) before being reconstructed in 2019. The well was initially constructed with a 6-in. diameter casing to a depth of about $20 \mathrm{ft}$ bls and below that depth was a 6-in. diameter open hole to $602 \mathrm{ft}$ bls (table 2). The depth to ambient water level at the time of logging was about $55 \mathrm{ft}$ bls. 
$\boldsymbol{A}$

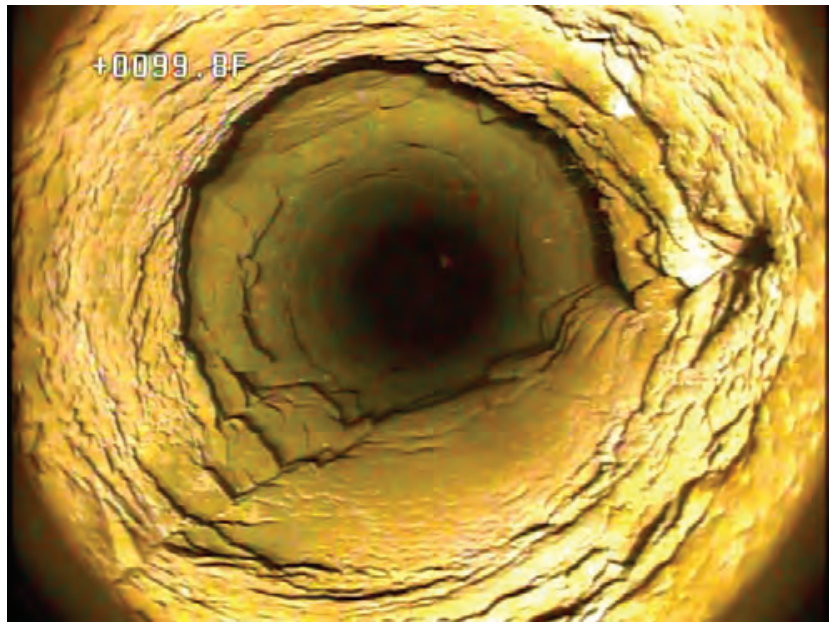

B

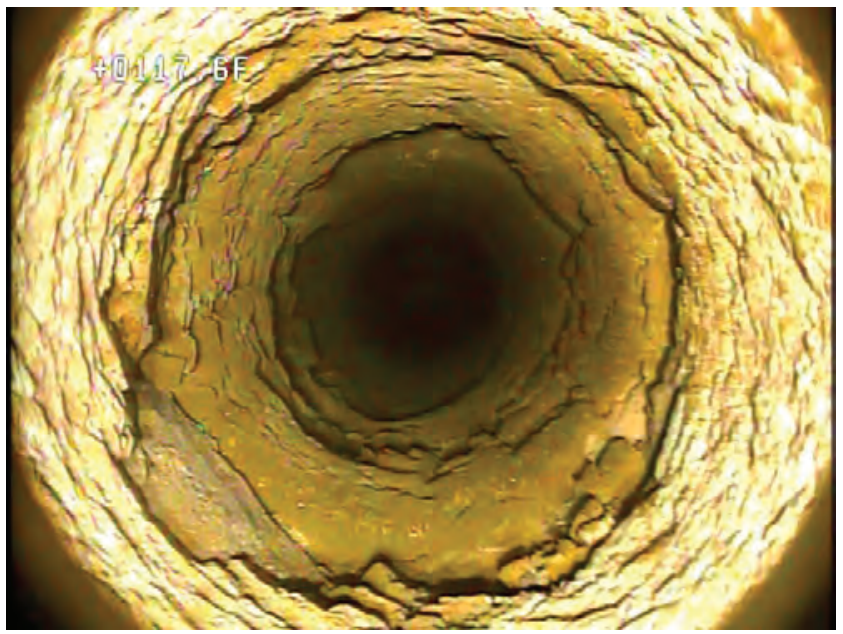

c

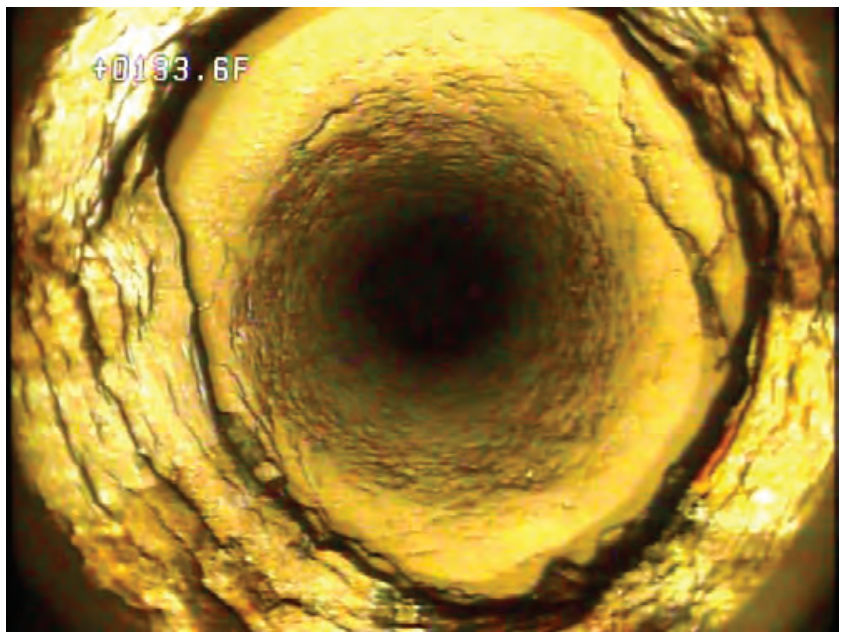

D

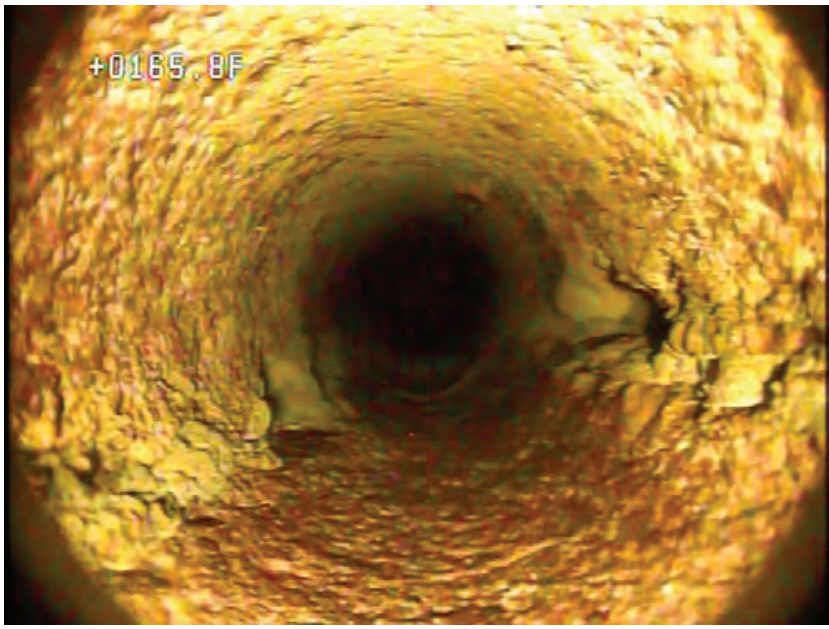

$\boldsymbol{E}$

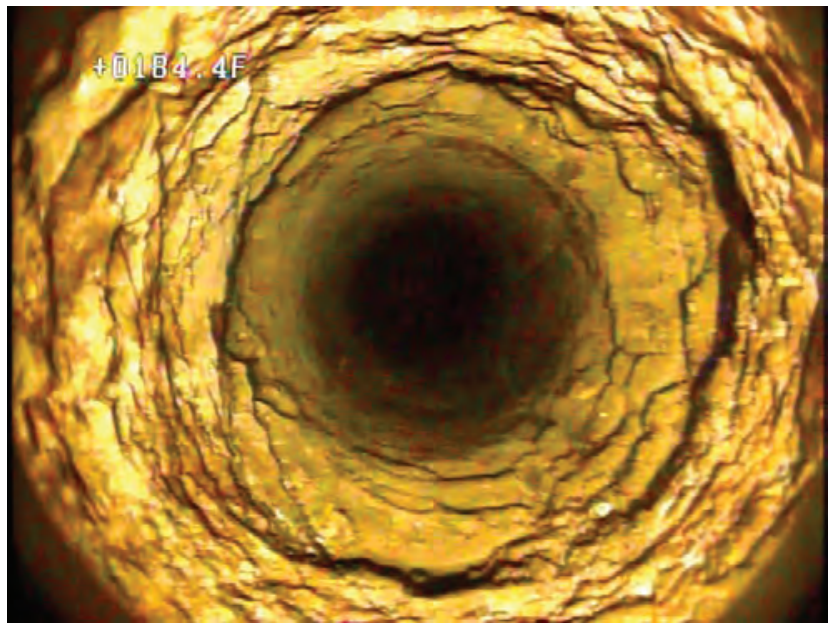

$\boldsymbol{F}$

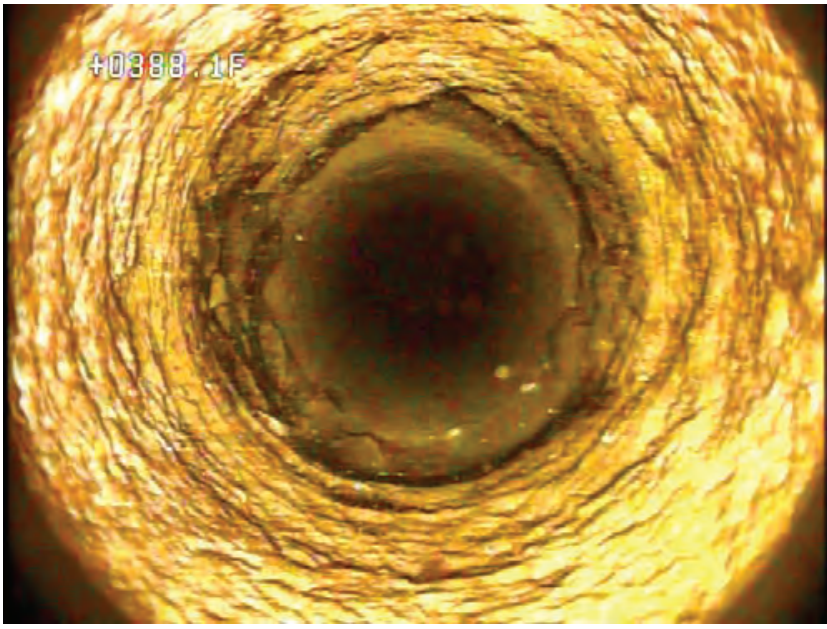

Figure 21. Still images from borehole video log of well BK-3062 (NBCMA 15) at $A, 99.8$ feet below land surface (ft bls) showing high-angle fractures and bedding-plane opening, $B, 117.6 \mathrm{ft}$ bls showing bedding-plane openings, $C, 133.6 \mathrm{ft}$ bls showing bedding-plane openings, $D, 165.8 \mathrm{ft}$ bls showing high-angle fractures, $E$, $184.4 \mathrm{ft}$ bls showing bedding-plane openings, and $F, 388.1 \mathrm{ft}$ bls bedding-plane openings. Video log collected by U.S. Geological Survey in well BK-3062, Warminster Township, Bucks County, Pennsylvania, November 9, 2017. 


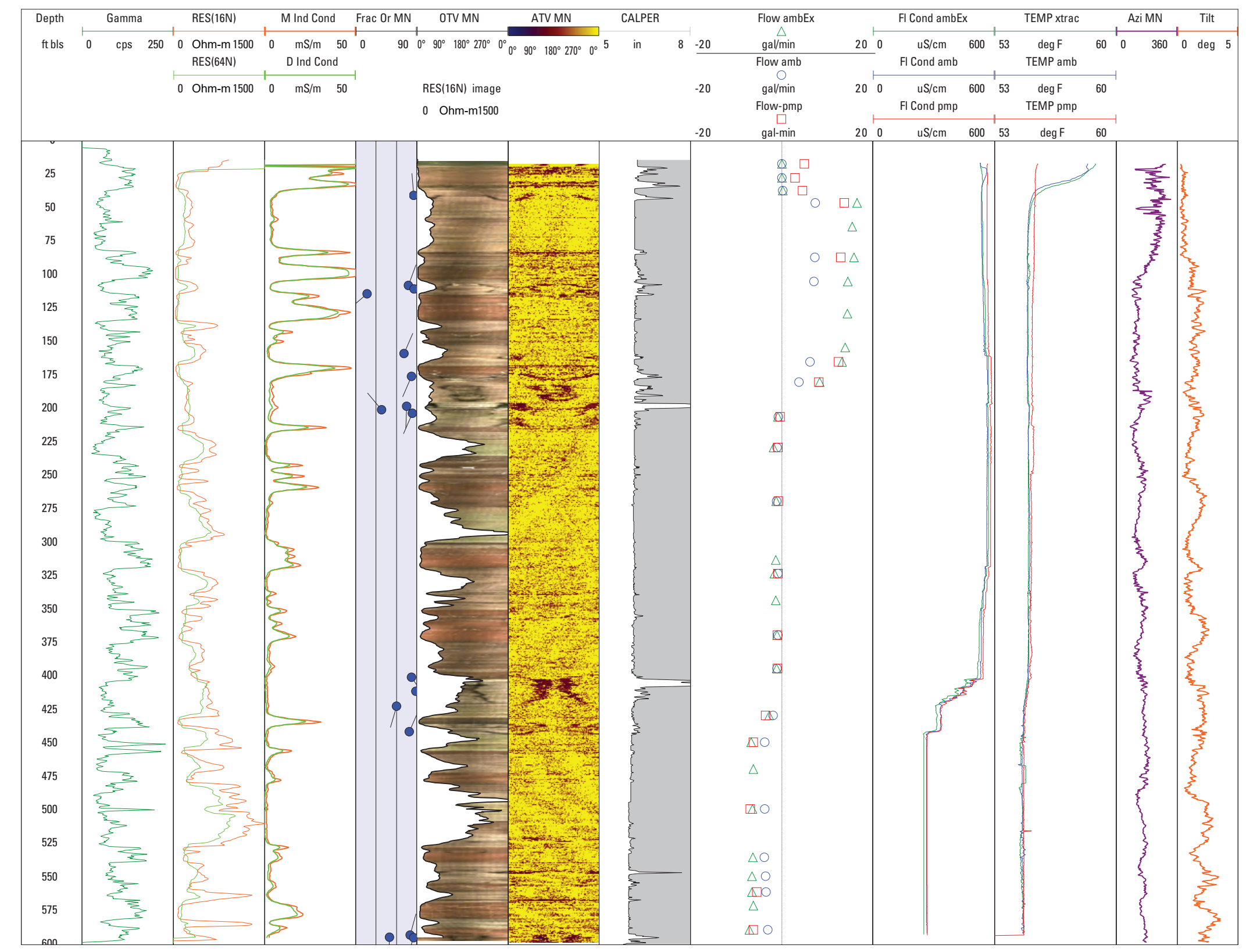

Figure 22. Geophysical logs collected by U.S. Geological Survey in well BK-3063 (HN-116), Warminster Township, Bucks County, Pennsylvania, May 24-25, 2018. See table 1 for explanation of abbreviations. Note that ambient flow and fluid logs were measured under conditions when nearby extraction wells were pumping (green symbols and lines) and not pumping (red). 
Table 13. Borehole flow-measurements collected by U.S. Geological Survey in well BK-3063 (HN-116), Warminster Township, Bucks County, Pennsylvania, May 24-25, 2018. Stationary measurements made using an electromagnetic flow meter under ambient and pumping conditions; negative values indicate downward flow and positive values indicate upward flow. Ambient flow collected on May 24 when nearby extraction wells were pumping and on May 25 when nearby extraction wells were shutdown. Ambient and in-well pumping flow collected on May 25 when nearby extraction wells were shutdown. Flow values reported in table reflect corrections to raw measurements based on zero flow in casing under ambient conditions and known flow in casing under pumping conditions.

[ft, feet; bls, below land surface; corr, corrected value; gal/min, gallons per minute; amb, ambient conditions; pmp, pumping conditions; --, no data]

\begin{tabular}{|c|c|c|c|c|c|}
\hline \multicolumn{2}{|c|}{$\begin{array}{c}\text { May 23, 2018, nearby pumping on, ambient } \\
\text { conditions }\end{array}$} & \multicolumn{2}{|c|}{$\begin{array}{c}\text { May 24, 2018, nearby pumping off, ambient } \\
\text { conditions }\end{array}$} & \multicolumn{2}{|c|}{$\begin{array}{c}\text { May 24, 2018, nearby pumping off, pumping } \\
\text { conditions }\end{array}$} \\
\hline Depth (ft bls) & Flow amb1, corr (gal/min) & Depth (ft bls) & Flow amb2, corr (gal/min) & Depth (ft bls) & Flow pmp3, corr (gal/min) \\
\hline 18 & 0.00 & 18 & 0.00 & 18 & 5.00 \\
\hline 28.5 & 0.02 & 28.5 & 0.01 & 28.5 & 2.95 \\
\hline 38 & 0.25 & 38 & 0.23 & 38 & 4.60 \\
\hline 47 & 16.48 & 47 & 7.40 & 47 & 13.70 \\
\hline 65 & 15.44 & 65 & -- & 65 & -- \\
\hline 88 & 15.87 & 88 & 7.23 & 88 & 12.97 \\
\hline 106 & 14.54 & 106 & 7.07 & 106 & -- \\
\hline 130 & 14.42 & 130 & -- & 130 & -- \\
\hline 155 & 13.90 & 155 & -- & 155 & -- \\
\hline 166 & 13.21 & 166 & 6.22 & 166 & 12.47 \\
\hline 181 & 8.30 & 181 & 3.78 & 181 & 8.16 \\
\hline 207 & -0.86 & 207 & -0.77 & 207 & -0.33 \\
\hline 230 & -1.77 & 230 & -1.04 & 230 & -0.82 \\
\hline 270 & -1.24 & 270 & -1.10 & 270 & -0.75 \\
\hline 314 & -1.32 & 314 & -- & 314 & -- \\
\hline 324 & -1.58 & 324 & -0.82 & 324 & -0.80 \\
\hline 344 & -1.32 & 344 & -- & 344 & -- \\
\hline 370 & -1.06 & 370 & -0.82 & 370 & -0.96 \\
\hline 395 & -1.06 & 395 & -0.97 & 395 & -0.94 \\
\hline 430 & -2.75 & 430 & -1.87 & 430 & -3.53 \\
\hline 450 & -6.72 & 450 & -3.67 & 450 & -6.23 \\
\hline 470 & -6.21 & 470 & -- & 470 & -- \\
\hline 500 & -6.43 & 500 & -3.75 & 500 & -6.90 \\
\hline 536 & -6.33 & 536 & -3.77 & 536 & -- \\
\hline 550 & -6.51 & 550 & -3.48 & 550 & -- \\
\hline 562 & -6.51 & 562 & -3.43 & 562 & -5.41 \\
\hline 572 & -6.23 & 572 & -- & 572 & -- \\
\hline 590 & -7.09 & 590 & -3.02 & 590 & -6.23 \\
\hline
\end{tabular}

${ }^{1}$ Flow measured on May 23, 2018, starting at 13:44 under ambient conditions in well BK-3063 and nearby extraction wells were pumping; depth to water was $9.60 \mathrm{ft}$ bls at 13:58 and fluctuated slightly during logging, ranging from a minimum of 9.42 ft bls at 14:43 to a maximum of 9.95 ft bls at 15:02 on May 23, 2018 .

2Flow measured on May 24, 2018, starting at 07:45 under ambient conditions in well BK-3063 and nearby extraction wells were not pumping; depth to water was $8.54 \mathrm{ft}$ bls at $07: 41$ and fluctuated slightly during logging under ambient conditions, ranging from a maximum of $8.58 \mathrm{ft}$ bls at $08: 41$ to a minimum of $8.29 \mathrm{ft}$ bls at 09:16 on May 24, 2018.

3Flow measured on May 24, 2018, starting at 11:44 under pumping conditions in well BK-3063; pump in well BK-3063 started at 11:03 at rate of 5 gal/min; nearby extraction wells were not pumping; depth to water was $8.22 \mathrm{ft}$ bls at 11:00 and $8.72 \mathrm{ft}$ bls at 11:40. 
$\boldsymbol{A}$

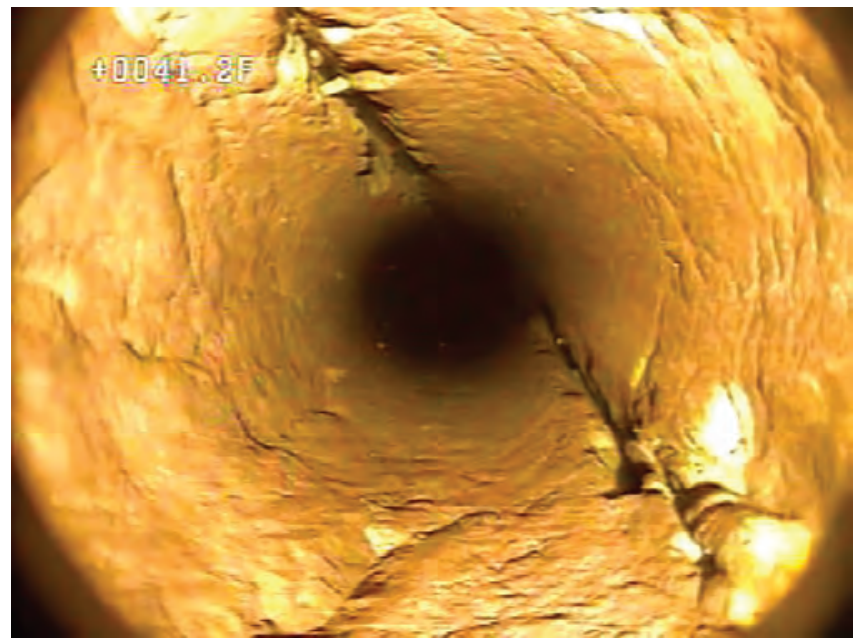

$B$

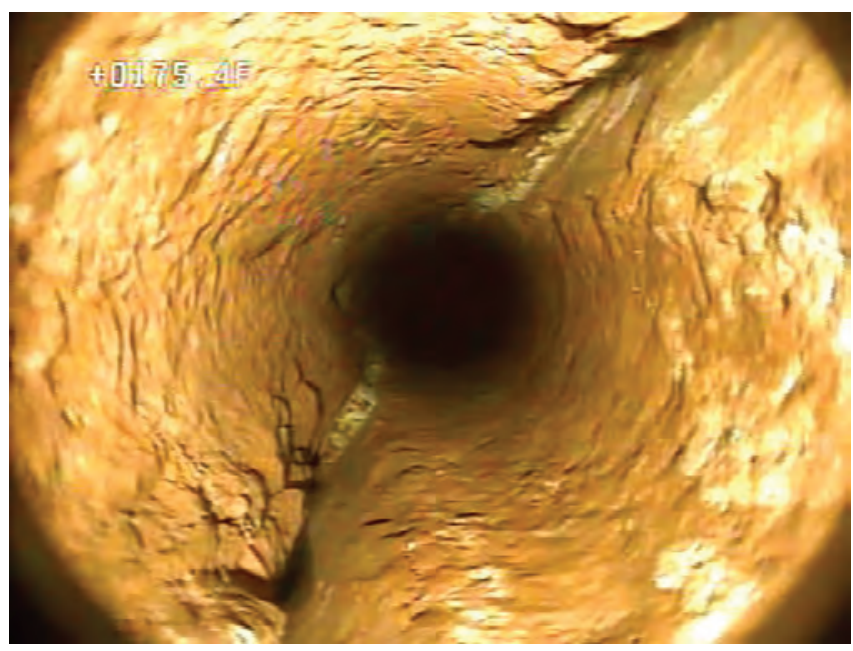

C

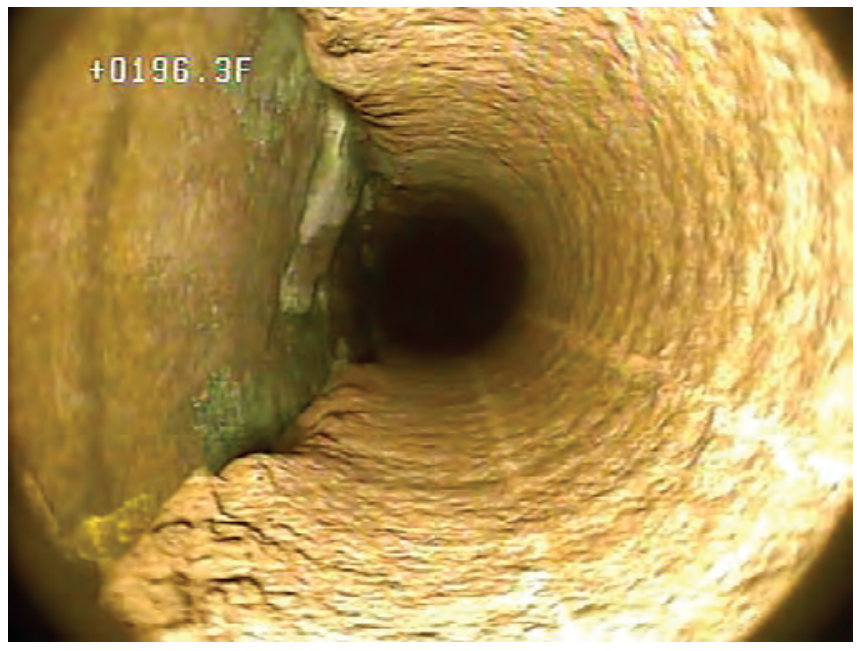

D

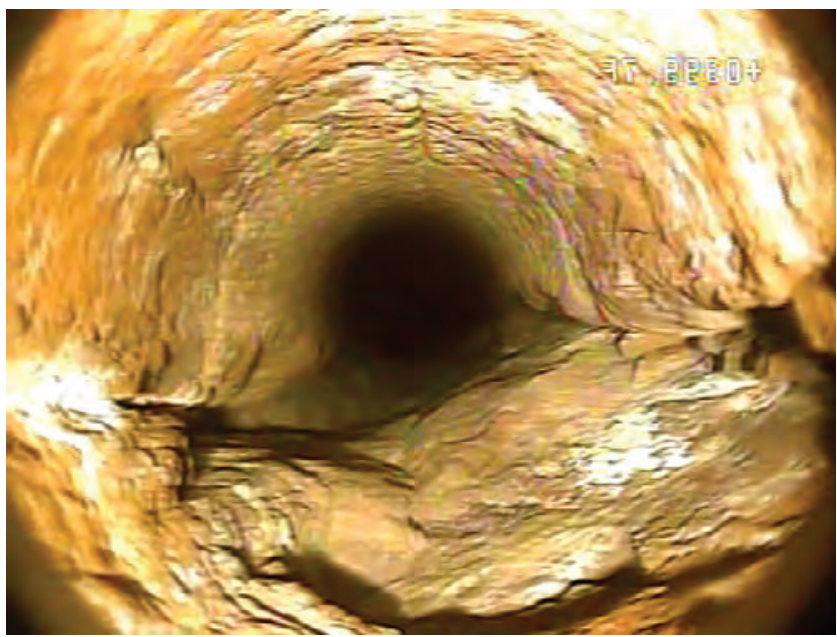

$E$

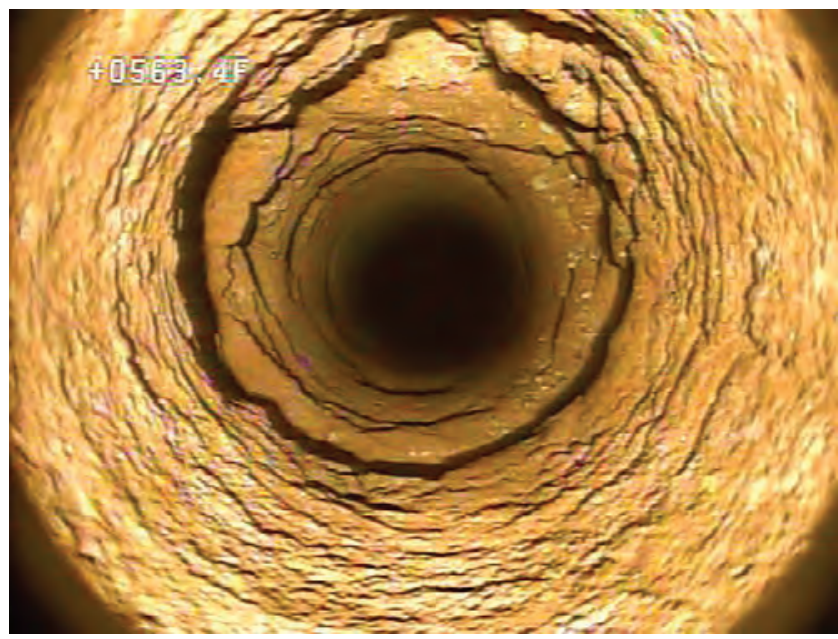

$\boldsymbol{F}$

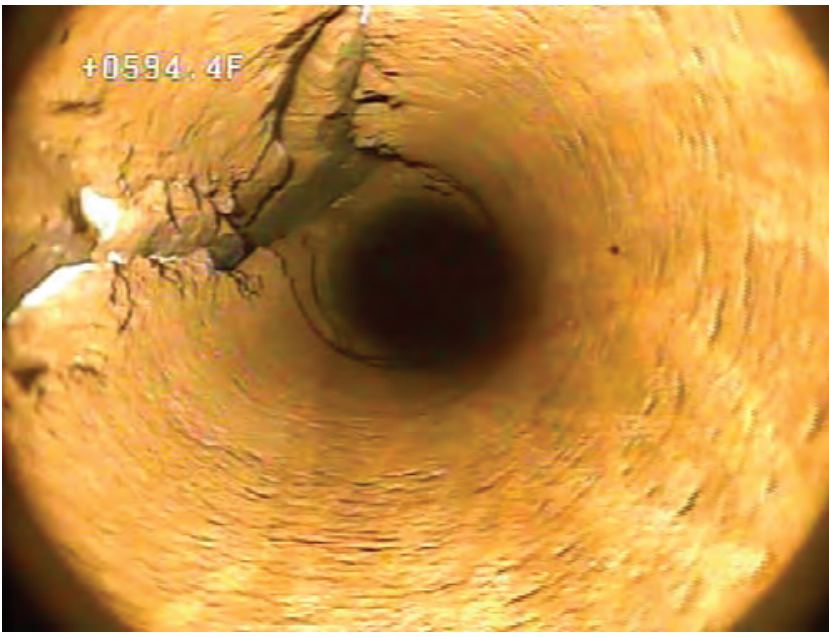

Figure 23. Still images from borehole video log of well BK-3063 (HN-116) at $A, 41.2$ feet below land surface (ft bls) showing high-angle fractures, $B, 175.4 \mathrm{ft}$ bls showing large high-angle fractures, $C, 196.3 \mathrm{ft}$ showing high-angle fracture plane at edge of borehole, $D, 399.7$ $\mathrm{ft}$ bls showing lithology change and high-angle fractures, $E, 563.4 \mathrm{ft}$ bls showing low-angle bedding-plane opening, and $F, 594.4 \mathrm{ft}$ bls showing high-angle fractures that terminates at bedding-plane opening. Video log collected by U.S. Geological Survey in well BK-3063, Warminster Township, Bucks County, Pennsylvania, May 21, 2018. 


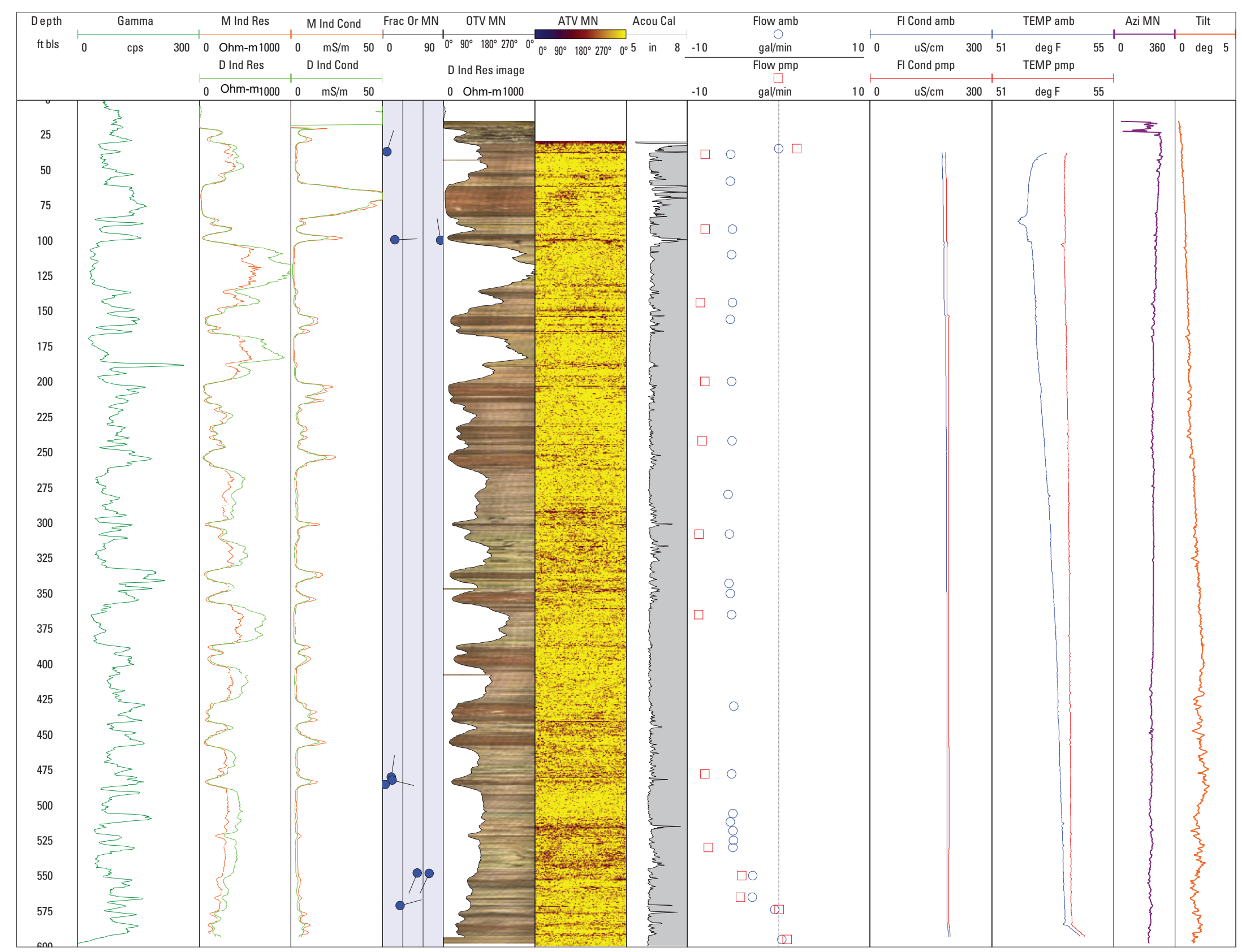

Figure 24. Geophysical logs collected by U.S. Geological Survey in well BK-3066 (HN-118), Warminster Township, Bucks County, Pennsylvania, August 6-7, 2018. See table 1 for explanation of abbreviations. 
Table 14. Borehole flow-measurements collected by U.S. Geological Survey in well BK-3066 (HN-118), Warwick Township, Bucks County, Pennsylvania, August 6-7, 2018. Stationary measurements made using an electromagnetic flow meter under ambient and pumping conditions; negative values indicate downward flow and positive values indicate upward flow. Flow values reported in the table reflect corrections to raw measurements based on zero flow in casing under ambient conditions and known flow in casing under pumping conditions.

[ft, feet; bls, below land surface; corr, corrected value; gal/min, gallons per minute; amb, ambient conditions; pmp, pumping conditions; --, no data]

\begin{tabular}{|c|c|c|c|}
\hline \multicolumn{2}{|c|}{ Ambient conditions } & \multicolumn{2}{|c|}{ Pumping conditions } \\
\hline Depth (ft bls) & $\begin{array}{c}\text { Flow amb } 1 \text {, corr } \\
\text { (gal } / \mathrm{min})\end{array}$ & Depth (ft bls) & $\begin{array}{l}\text { Flow pmp2, corr } \\
\text { (gal/min) }\end{array}$ \\
\hline 35 & 0.00 & 35 & 2.00 \\
\hline 39 & -5.24 & 39 & -8.01 \\
\hline 58 & -5.28 & 58 & -- \\
\hline 92 & -5.03 & 92 & -8.01 \\
\hline 110 & -5.16 & 110 & -- \\
\hline 144 & -5.03 & 144 & -8.54 \\
\hline 156 & -5.26 & 156 & -- \\
\hline 200 & -5.14 & 200 & -8.05 \\
\hline 242 & -5.10 & 242 & -8.38 \\
\hline 280 & -5.54 & 280 & -- \\
\hline 308 & -5.37 & 308 & -8.70 \\
\hline 343 & -5.44 & 343 & -- \\
\hline 350 & -5.28 & 350 & -- \\
\hline 365 & -5.13 & 365 & -8.74 \\
\hline 430 & -4.91 & 430 & -- \\
\hline 478 & -5.13 & 478 & -8.07 \\
\hline 506 & -4.98 & 506 & -- \\
\hline 512 & -5.28 & 512 & -- \\
\hline 518 & -4.98 & 518 & -- \\
\hline 525 & -4.95 & 525 & -- \\
\hline 530 & -5.00 & 530 & -7.67 \\
\hline 550 & -2.80 & 550 & -4.03 \\
\hline 565 & -2.84 & 565 & -4.17 \\
\hline 574 & -0.40 & 574 & 0.06 \\
\hline 595 & 0.37 & 595 & 0.94 \\
\hline
\end{tabular}

${ }^{1}$ Measured starting at 11:01 on August 7, 2018; depth to ambient water level was $30.82 \mathrm{ft}$ bls at 10:32 and $29.30 \mathrm{ft}$ bls at 13:36 on August 7, 2018.

2Pumping rate $2 \mathrm{gal} / \mathrm{min}$ started at 14:05 on August 7, 2018; flow measured under pumping conditions starting at 14:19 and ending at 15:21 on August 7, 2018; depth to water level was $30.45 \mathrm{ft}$ bls at $14: 15,29.96 \mathrm{ft}$ bls at $14: 41$, $29.46 \mathrm{ft}$ bls at 15:17, and 29.70 at 15:28 on August 7, 2018.
The caliper and ATV logs show numerous fractures throughout the borehole, with the largest openings at depths ranging from about 80 to 95,125 to 160 , and 175 to $185 \mathrm{ft}$ bls (fig. 26). Many fractures are low angle but fractures near 150, 180, and $390 \mathrm{ft}$ bls are high angle. Fluid and flow logs were collected only under ambient conditions. The fluidtemperature log collected under ambient conditions shows inflections near about $65,125,175$, and $580 \mathrm{ft}$ bls that could be used to identify depth of water-bearing fractures. The fluidconductivity logs collected under ambient conditions show similar inflections near about 65, 125 and $175 \mathrm{ft}$ bls.

The flow log collected under ambient conditions indicates downward flow at depths below $64 \mathrm{ft}$ bls, with downward flow increasing between depths of 78-91, 118-144, 144-165, and also 176-194 ft bls, then decreasing between depths of 520 and $566 \mathrm{ft}$ bls, and decreasing again below $595 \mathrm{ft}$ bls (table 15). This pattern indicates that water probably enters the borehole through the fractures above $64 \mathrm{ft}$ bls, near about 125 , 150 , and $185 \mathrm{ft}$ bls, then flows down to exit fractures near 540 and below $595 \mathrm{ft}$ bls under ambient conditions at the time of logging.

The borehole video log, collected by USGS on August 6, 2018 , when the water level was $54.9 \mathrm{ft}$ bls, showed numerous horizontal and vertical fractures throughout the borehole. Water was observed cascading into the borehole at depths of about 20.9, 29.4, and 31-35 ft bls, above the static water level. Probable water-bearing zones were noted for fractures at about 81.9, 151-153, 170.4, 177.6-185.3, 339, 371.7, 381.9, and $572-573 \mathrm{ft}$ bls. Other possible water-bearing fractures were noted throughout the borehole. In addition, possible waterbearing fractures indicated by geophysical logs also included those observed at depths of 543, 544, 553.8, 563.2 (horizontal fractures) and $595 \mathrm{ft}$ bls. Turbulence was observed near fractures at about 81.9, 120.4, and $339 \mathrm{ft}$ bls. Video-log images for selected fractures or openings in well BK-3066 are shown in figure 27.

\section{BK-3068 (HN-117)}

Well BK-3068 is a new monitor well (HN-117) drilled by the Navy on the former NAWC Warminster base (figs. 1 and 3 ) that was logged and subsequently tested by USGS using straddle packers to isolate discrete intervals for hydraulic characterization and sampling in 2018 (Senior and others, 2020) before being reconstructed in 2019. The well was initially constructed with a 6-in. diameter casing to a depth of about $19 \mathrm{ft}$ bls and below that depth was a 6-in. diameter open hole to $600 \mathrm{ft}$ bls (table 2). The depth to ambient water level at the time of logging was about $15.4 \mathrm{ft}$ bls.

The caliper and ATV logs show numerous fractures throughout the borehole, with the largest openings at depths in the range of 19 to $70 \mathrm{ft}$ bls (fig. 28). Most fractures are low angle except for fractures near 25 and $325 \mathrm{ft}$ bls that are high angle. The fluid-temperature logs collected under ambient and pumping conditions show the largest inflections at similar depths of about 45, 200, and $515 \mathrm{ft}$ bls that could be used to 
$\boldsymbol{A}$

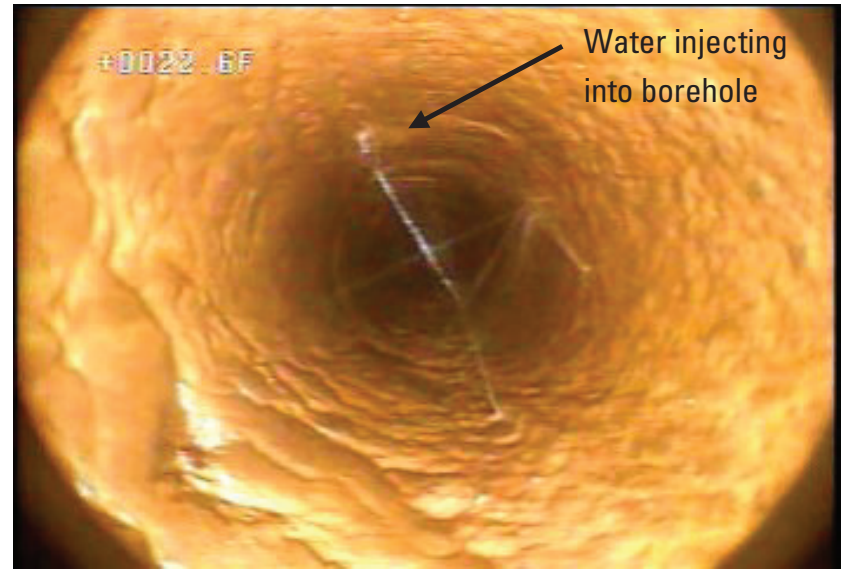

B

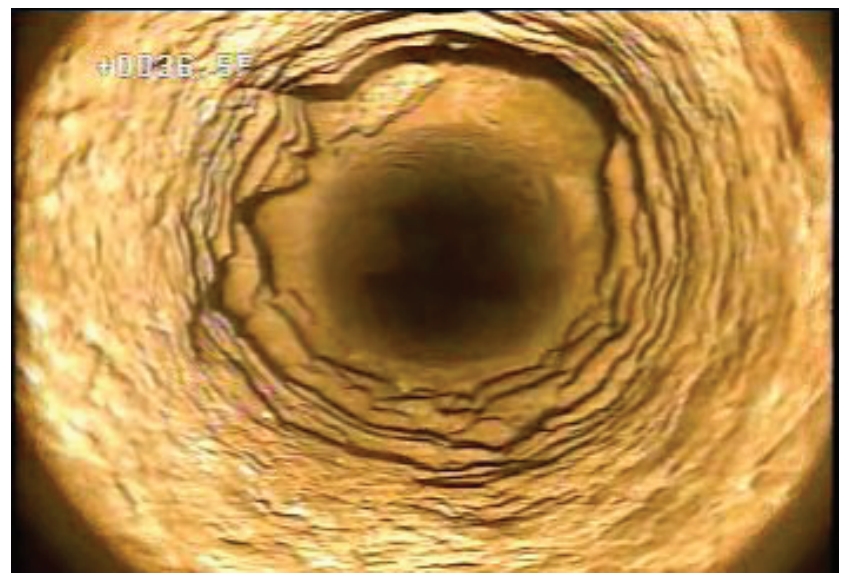

C

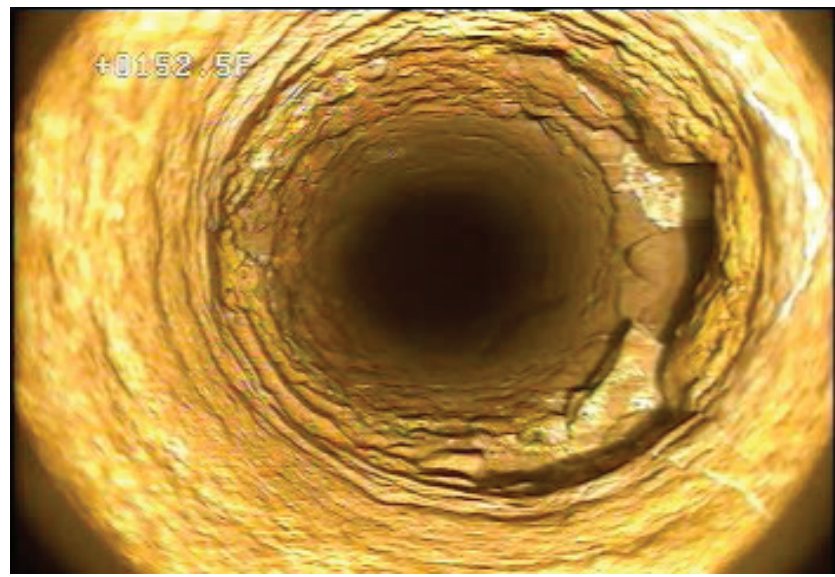

D

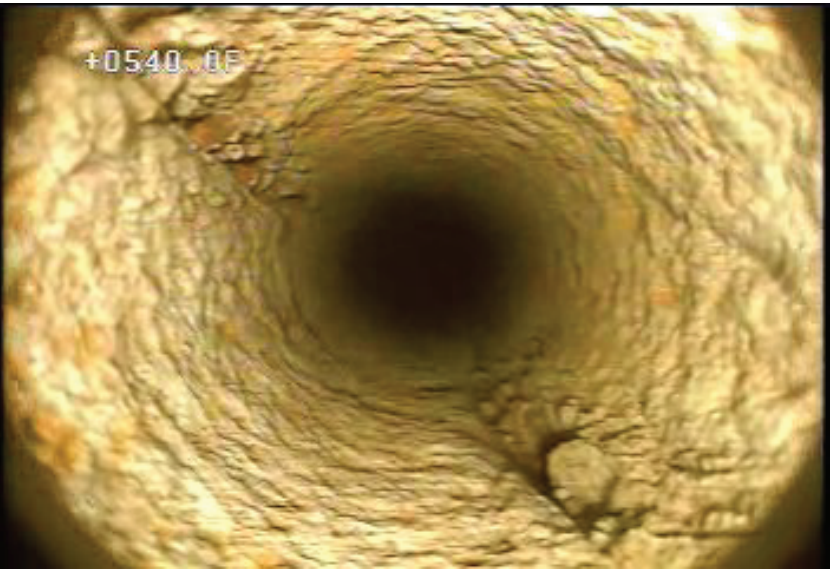

$E$

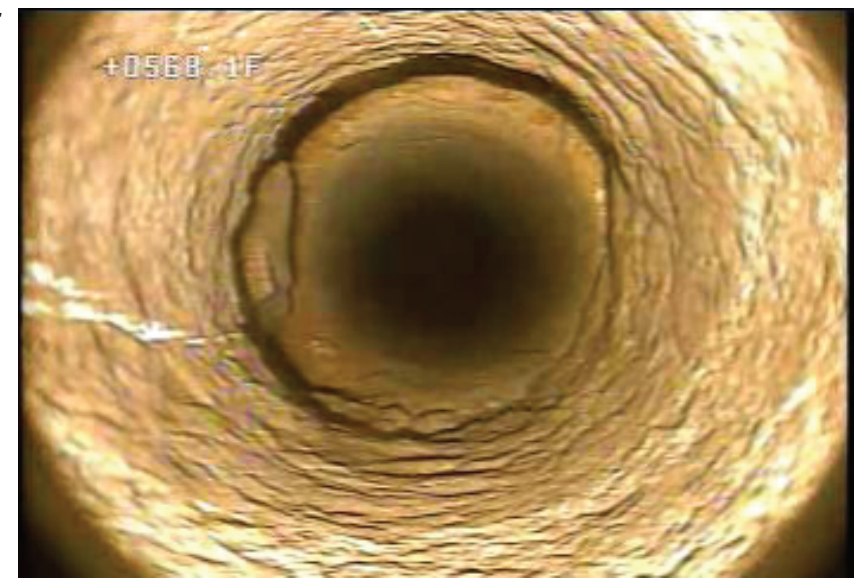

$\boldsymbol{F}$

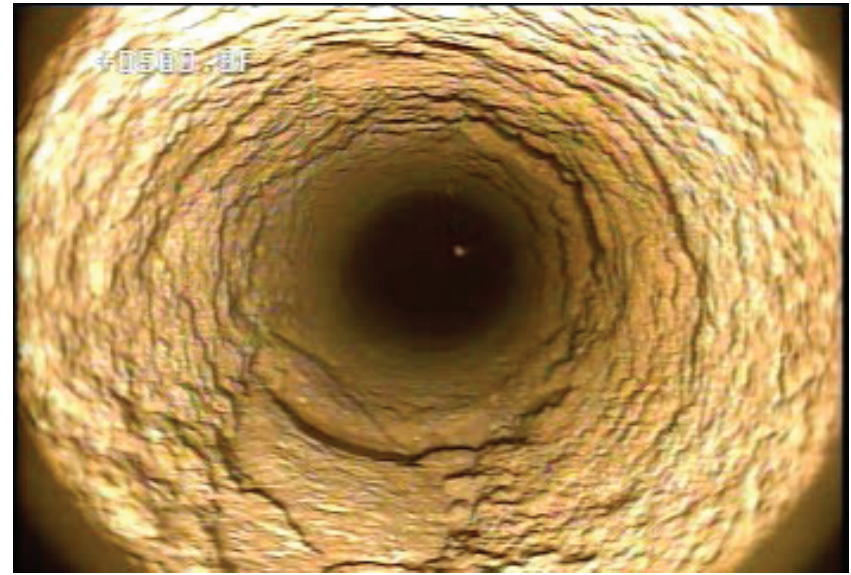

Figure 25. Still images from borehole video log of well BK-3066 (HN-118) at $A, 22.6$ feet below land surface (ft bls) showing water injecting into well from fractures above static water level of $32.8 \mathrm{ft}$ bls, $B, 36.5 \mathrm{ft}$ bls showing bedding-plane openings, $C, 152.5 \mathrm{ft}$ bls showing bedding-plane openings near where turbulence was observed, $D, 540.0 \mathrm{ft}$ bls showing high-angle fractures, $E, 568.1 \mathrm{ft} \mathrm{bls}$ showing bedding-plane openings, and $F, 580.1 .1 \mathrm{ft}$ bls showing bedding-plane openings. Video log collected by U.S. Geological Survey in well BK-3066, Warminster Township, Bucks County, Pennsylvania, August 2, 2018. 


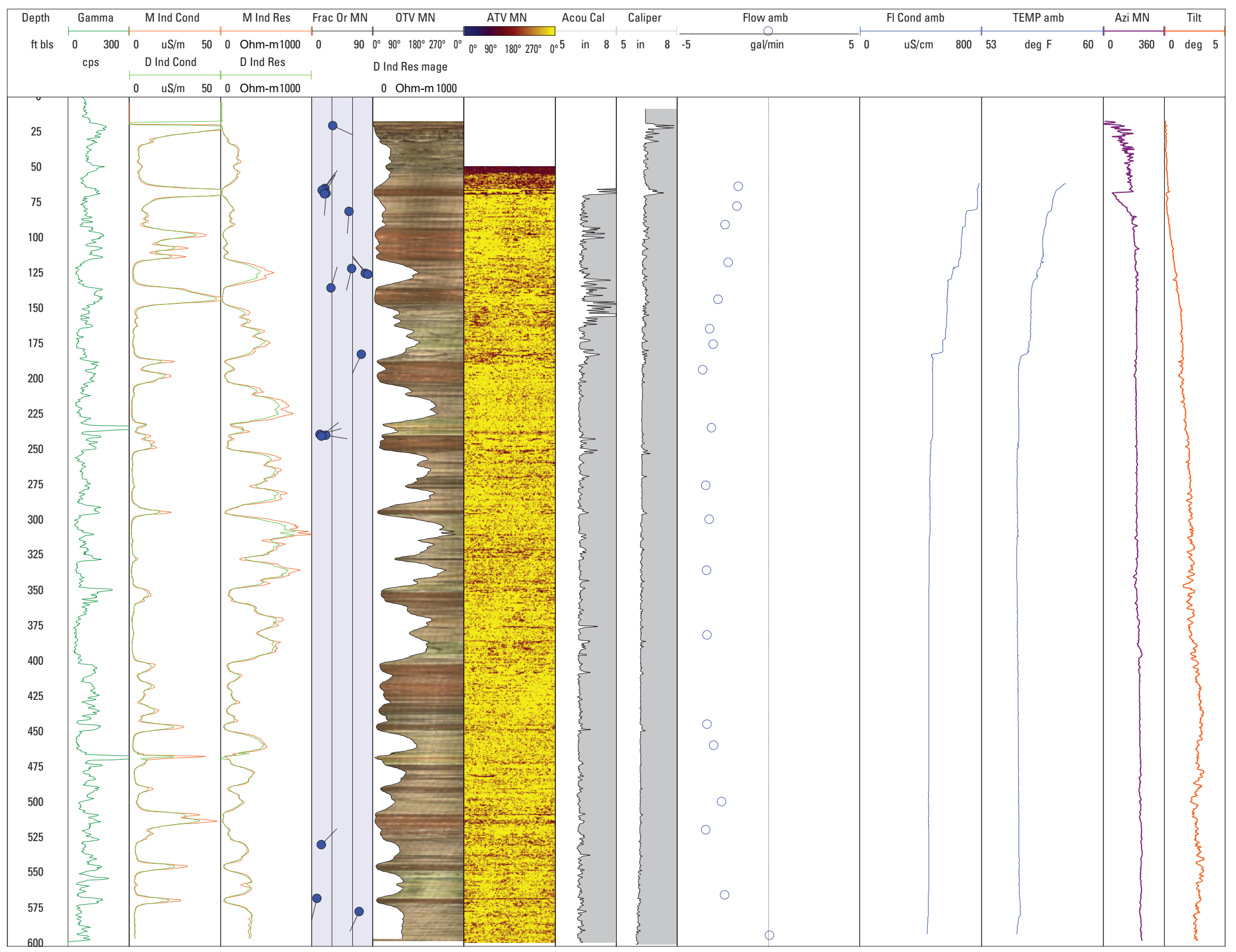

Figure 26. Geophysical logs collected by U.S. Geological Survey in well BK-3067 (HN-119), Warminster Township, Bucks County, Pennsylvania, August 8, 2018. See table 1 for explanation of abbreviations. 
Table 15. Borehole flow-measurements collected by U.S. Geological Survey in well BK-3067 (HN-119), Northampton Township, Bucks County, Pennsylvania, August 8, 2018. Stationary measurements made using an electromagnetic flow meter under ambient conditions; negative values indicate downward flow and positive values indicate upward flow. Flow values reported in table are raw measurements (not corrected).

[ft, feet; bls, below land surface; gal/min, gallons per minute; amb, ambient conditions]

\begin{tabular}{|c|c|}
\hline \multicolumn{2}{|c|}{ Ambient conditions } \\
\hline Depth (ft bls) & Flow amb ${ }^{1}$ (gal/min) \\
\hline 64 & -1.65 \\
\hline 78 & -1.72 \\
\hline 91 & -2.37 \\
\hline 118 & -2.21 \\
\hline 144 & -2.75 \\
\hline 165 & -3.23 \\
\hline 176 & -3.02 \\
\hline 194 & -3.61 \\
\hline 235 & -3.12 \\
\hline 276 & -3.44 \\
\hline 300 & -3.25 \\
\hline 336 & -3.39 \\
\hline 382 & -3.36 \\
\hline 445 & -3.37 \\
\hline 460 & -2.99 \\
\hline 500 & -2.56 \\
\hline 520 & -3.44 \\
\hline 566 & -2.41 \\
\hline 595 & 0.07 \\
\hline
\end{tabular}

${ }^{1}$ Flow measured under ambient conditions only starting at 13:39 on August 8, 2018; cascading water can be heard.

identify depth of water-bearing fractures. The fluid-conductivity logs collected under ambient and pumping conditions also show the largest inflections at about 45,200, and $515 \mathrm{ft}$ bls.

The flow log collected under ambient conditions indicates downward flow at depths below $19 \mathrm{ft}$ bls but above 515 $\mathrm{ft}$ bls, with downward flow increasing most between depths of 19 and $35 \mathrm{ft}$ bls and more gradually between depths of 35 and $200 \mathrm{ft}$ bls, then decreasing slightly between depths of 322 and 340 and also between 495 and $509 \mathrm{ft}$ bls (table 16). Small rates of upward flow were measured at 515 and $595 \mathrm{ft}$ bls under ambient conditions (table 16). This pattern indicates that water probably enters the borehole through the fractures near the bottom of casing at 19 to $35 \mathrm{ft}$ bls and also near numerous fractures in the range of depths from about 40 to $200 \mathrm{ft}$, including possibly near 45, 70, and $200 \mathrm{ft}$ bls; water then flows down to exit fractures near 325 and $500 \mathrm{ft}$ bls under ambient conditions at the time of logging. Under these conditions, water also enters the borehole below depths of $595 \mathrm{ft}$ and appears to flow up to exit fractures near $500 \mathrm{ft}$ bls. The flow log collected under pumping conditions (table 16) indicated that the fractures at depths above 32 and near $45 \mathrm{ft}$ bls appear to be among the most hydraulically active water-bearing zones in the well.

The borehole video log, collected by USGS on August 28, 2018, when the water level was $14.8 \mathrm{ft}$ bls, showed numerous horizontal and vertical fractures throughout the borehole and that the bottom of casing is $18.5 \mathrm{ft}$ bls. Probable water-bearing zones were noted for fractures at about 18.5-30.4, 45.7-49.6, 64.9-70.7, 199.3, 327.5-333.5, 353.9, and 505.8-509.0 ft bls. Other possible water-bearing fractures were noted at 77.3-78.5 and $499.4 \mathrm{ft}$ bls and elsewhere throughout the borehole. In addition, possible water-bearing fractures indicated by geophysical logs also included those observed at a depth of $596 \mathrm{ft}$ bls. Turbulence was observed near fractures at about 18.5, 77.3-78.5, and $199.3 \mathrm{ft}$ bls, with water injecting into the well at $199.3 \mathrm{ft}$ bls. Video-log images for selected fractures or openings in well BK-3068 are shown in figure 29.

\section{BK-3069 (HN-120S)}

Well BK-3069 is a new monitor well (HN-120S) drilled by the Navy on the former NAWC Warminster base (figs. 1 and 3) on October 23-24, 2018. The well was initially constructed with a 6 -in. diameter casing to a depth of about $19 \mathrm{ft}$ bls and below that depth was a 6-in. diameter open hole to 425 $\mathrm{ft}$ bls (table 2), but the borehole could not be completed to the target depth of $600 \mathrm{ft}$ bls because of concern about ground collapse near the well head during drilling on October 24, 2018. The hole collapsed near $29 \mathrm{ft}$ after drilling and was subsequently grouted to about that depth by the Navy's contractor.

The borehole video log collected by USGS on November 7, 2018, when the ambient water level was $12.6 \mathrm{ft}$ bls was run only to a depth of $26 \mathrm{ft}$ bls because of an obstruction near that depth. The video log showed large fractures and openings from below the bottom of the casing at $19 \mathrm{ft}$ bls to $26 \mathrm{ft}$ bls. The USGS did not collect geophysical logs in well BK-3069 (HN-120I). Video-log images for selected fractures or openings in well BK-3069 are shown in figure 30.

\section{BK-3070 (HN-120D)}

Well BK-3070 is a new monitor well (HN-120D) drilled by the Navy on the former NAWC Warminster base (figs. 1 and 3) that was logged and subsequently tested by USGS using straddle packers to isolate discrete intervals for hydraulic characterization and sampling in 2018 (Senior and others, 2020) before being reconstructed in 2019. The well was initially constructed with a 6 -in. diameter casing to a depth of about $59 \mathrm{ft}$ bls and below that casing was a 6 -in. diameter open hole to a reported depth of $580 \mathrm{ft}$ bls, although at the 
$\boldsymbol{A}$

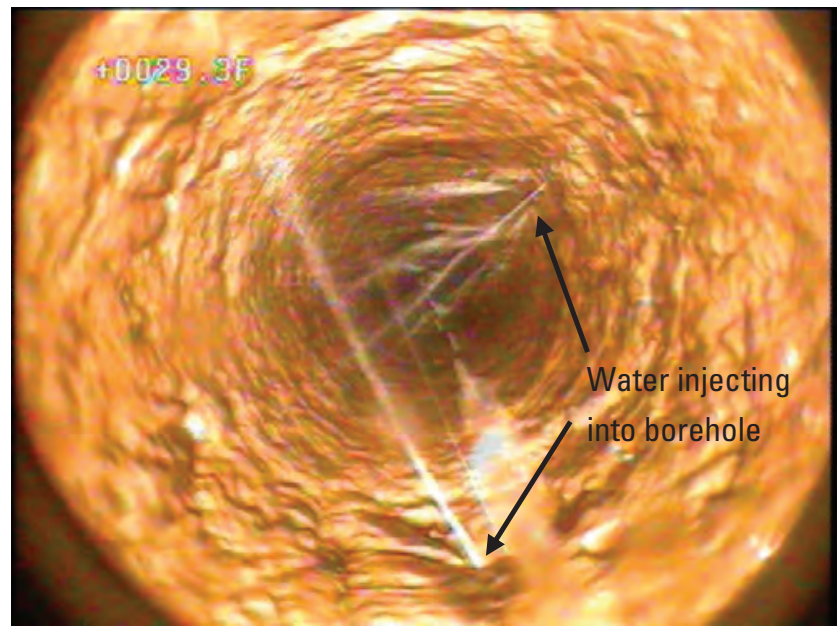

$B$

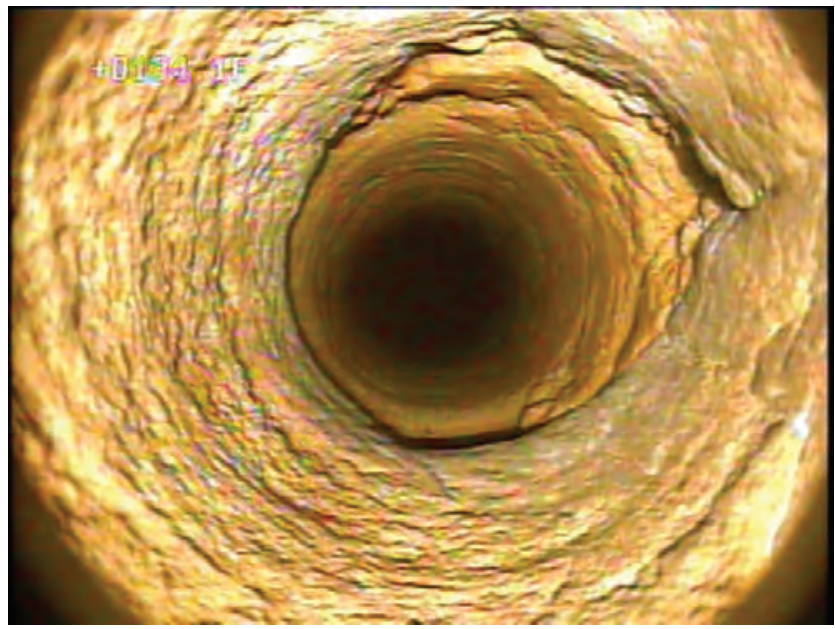

C

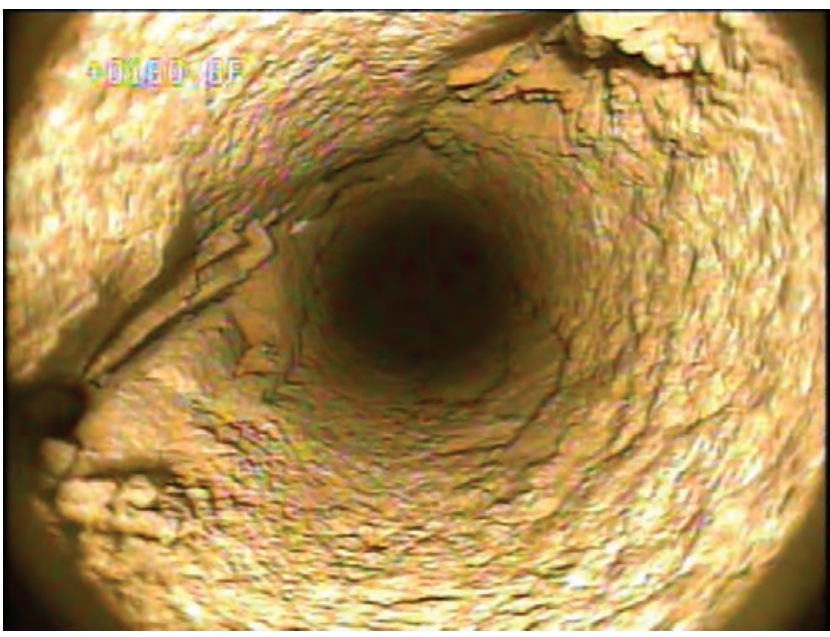

D

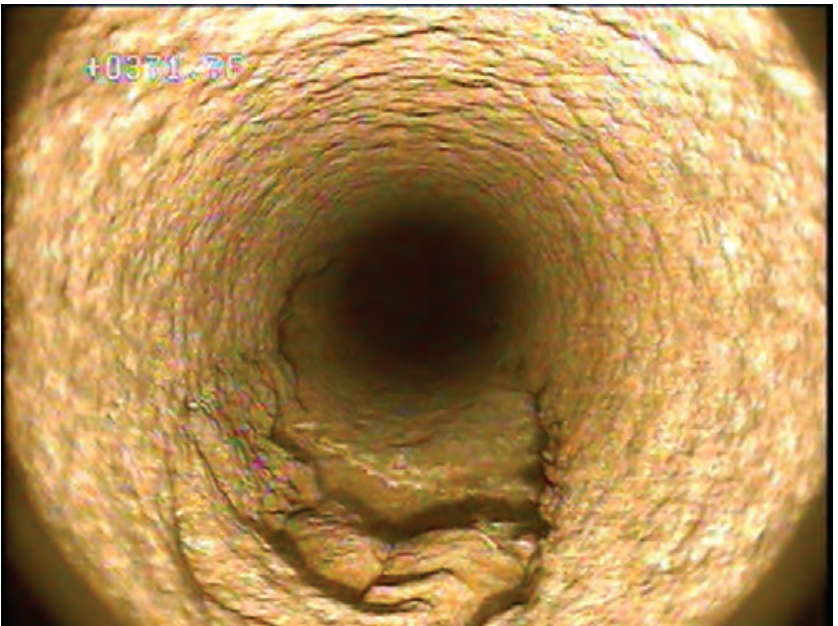

$E$

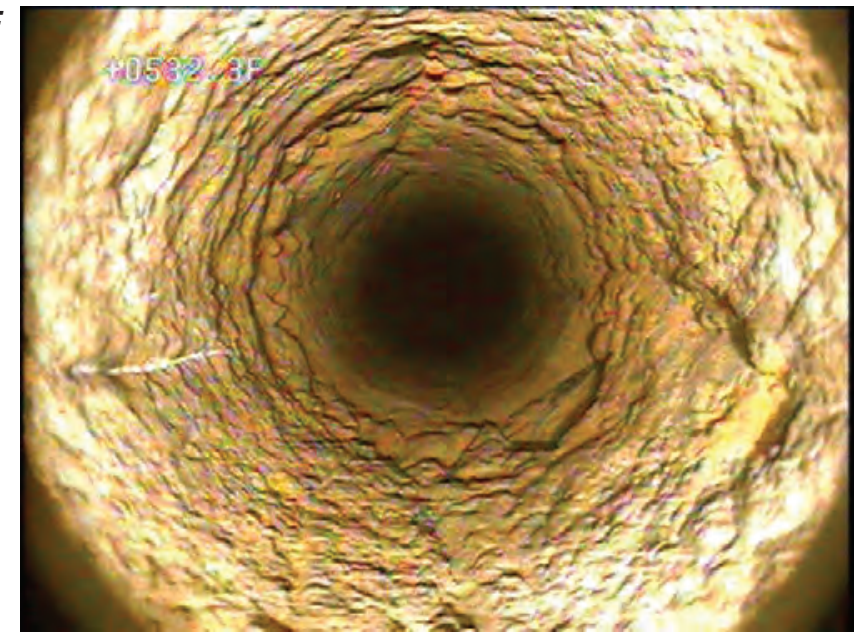

$\boldsymbol{F}$

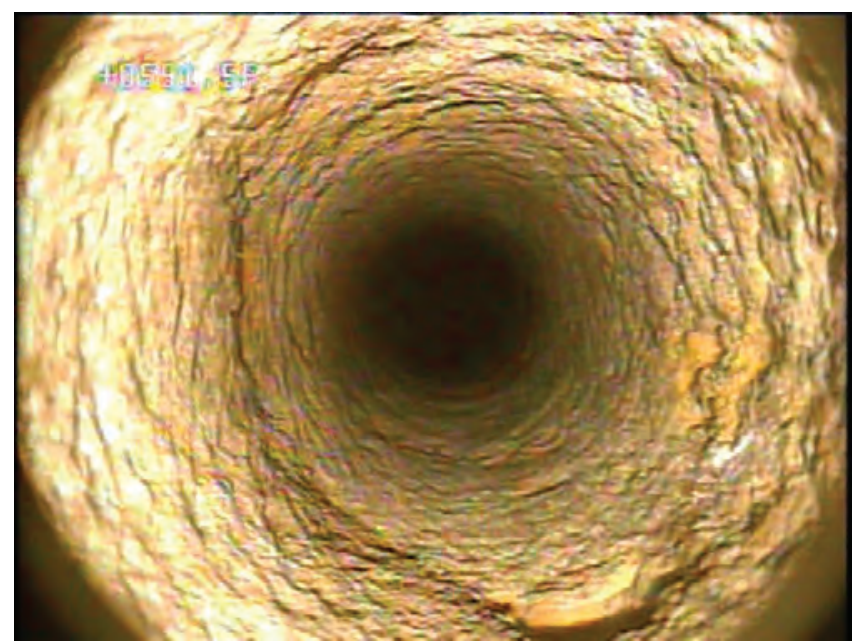

Figure 27. Still images from borehole video log of well BK-3067 (HN-119) at $A, 29.3$ feet below land surface (ft bls) showing water injecting into well from fractures above static water level of $54.9 \mathrm{ft}$ bls, $B, 134.1 \mathrm{ft}$ bls bedding-plane openings at change in lithology, $C$, $180.7 \mathrm{ft}$ bls showing high-angle fractures, $D, 371.4 \mathrm{ft}$ bls showing high-angle fractures, $E, 532.3 \mathrm{ft}$ bls showing bedding-plane openings, and $F, 591.5 \mathrm{ft}$ bls showing bedding-plane openings. Video log collected by U.S. Geological Survey in well BK-3067, Warminster Township, Bucks County, Pennsylvania, August 6, 2018. 


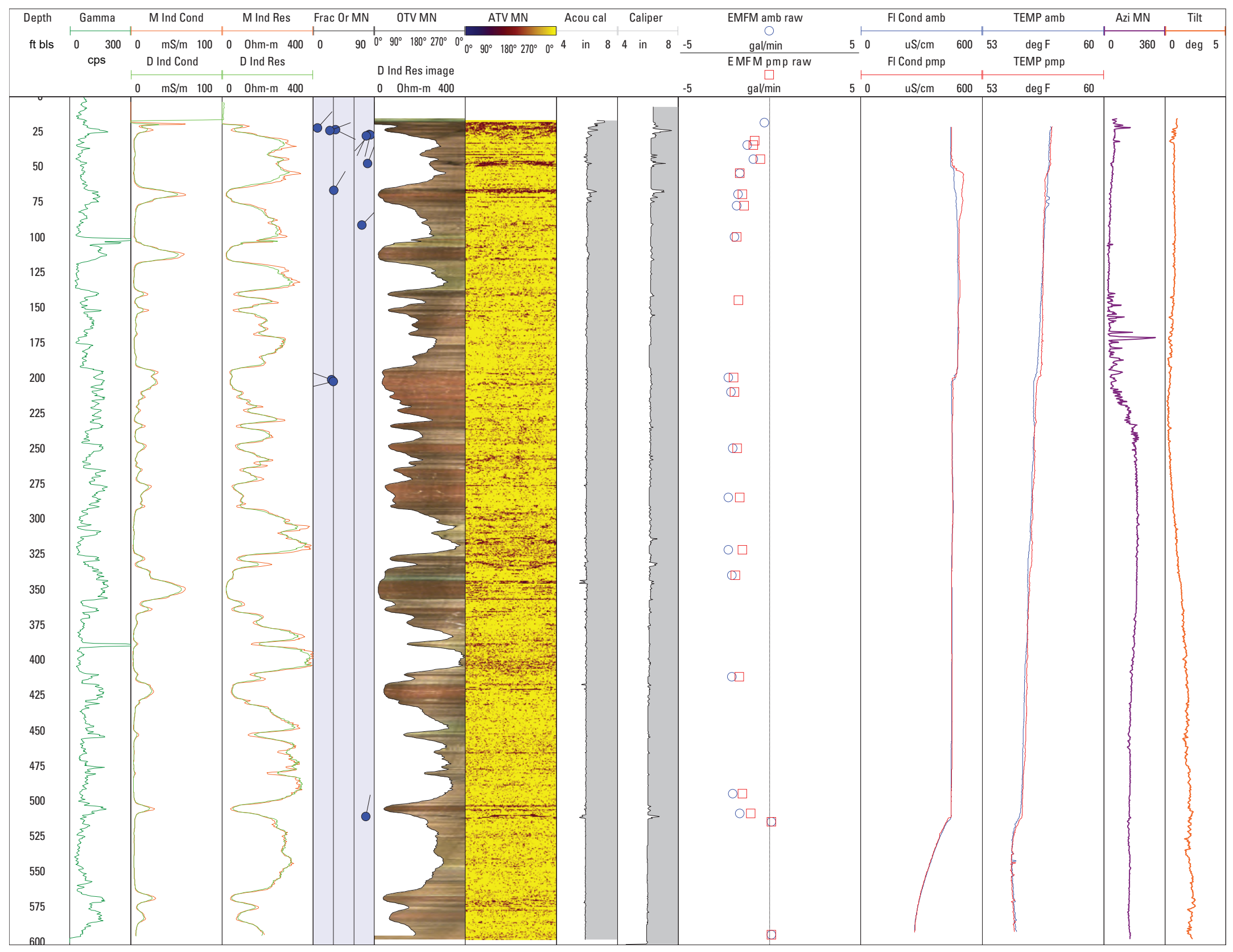

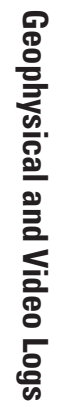

Figure 28. Geophysical logs collected by U.S. Geological Survey in well BK-3068 (HN-117), Warminster Township, Bucks County, Pennsylvania, August 9, 2018. See table 1 for explanation of abbreviations. 
Table 16. Borehole flow-measurements collected by U.S. Geological Survey in well BK-3068 (HN-117), Warminster Township, Bucks County, Pennsylvania, August 9, 2018. Stationary measurements made using an electromagnetic flow meter under ambient and pumping conditions; negative values indicate downward flow and positive values indicate upward flow. Flow values reported in table are raw measurements (not corrected). Flow values at 45 feet below land surface may be smaller than actual because of borehole rugosity enlarging hole diameter.

[ft, feet; bls, below land surface; gal/min, gallons per minute; amb, ambient conditions; pmp, pumping conditions; --, no data]

\begin{tabular}{cccc}
\hline \multicolumn{2}{c}{ Ambient conditions } & \multicolumn{2}{c}{ Pumping conditions } \\
\hline Depth (ft bls) & $\begin{array}{c}\text { Flow amb1 } \\
\text { (gal/min) }\end{array}$ & Depth (ft bls) & $\begin{array}{c}\text { Flow pmp2 } \\
\text { (gal/min) }\end{array}$ \\
\hline 19 & -0.28 & 19 & -- \\
32 & -- & 32 & -0.81 \\
35 & -1.23 & 35 & -0.88 \\
45 & -0.88 & 45 & -0.50 \\
55 & -1.63 & 55 & -1.63 \\
70 & -1.72 & 70 & -1.48 \\
78 & -1.80 & 78 & -1.38 \\
100 & -1.91 & 100 & -1.79 \\
145 & -- & 145 & -1.70 \\
200 & -2.24 & 200 & -1.96 \\
210 & -2.12 & 210 & -1.92 \\
250 & -2.01 & 250 & -1.78 \\
285 & -2.26 & 285 & -1.62 \\
322 & -2.25 & 322 & -1.49 \\
340 & -2.06 & 340 & -1.88 \\
412 & -2.06 & 412 & -1.64 \\
495 & -2.00 & 495 & -1.47 \\
509 & -1.62 & 509 & -0.03 \\
515 & 0.10 & 515 & 0.10 \\
595 & 0.10 & 595 & 0.10 \\
\hline
\end{tabular}

1Flow measured starting at 11:52 on August 9, 2018.

2Pumping rate $2.5 \mathrm{gal} / \mathrm{min}$; flow measured starting at 13:58 on August 9, 2018.

time of logging was only open to about $555 \mathrm{ft}$ bls (table 2). The depth to ambient water level at the time of logging was about $15.4 \mathrm{ft}$ bls. Well BK-3070 (HN-120D) was the second deep, new monitor well drilled at this location, to replace the first well (BK-3069, reconstructed as HN-120I) that could not be completed to a depth of $600 \mathrm{ft}$ because of concern about ground collapse near the well head during drilling on October 23-24, 2018.

The caliper and ATV logs show numerous fractures throughout the borehole, with the largest openings at depths in the range of 59 to $140 \mathrm{ft}$ bls and near $195 \mathrm{ft}$ bls (fig. 31). Many fractures are low angle but fractures near 100, 195, 350, and $375 \mathrm{ft}$ bls are high angle. The fluid-temperature logs collected under ambient and pumping conditions show the largest inflections at similar depths of about $60,195,230$ and $380 \mathrm{ft}$ bls that could be used to identify depth of water-bearing fractures. The fluid-temperature log collected under pumping conditions also shows a small inflection near $290 \mathrm{ft}$ bls. The fluid-conductivity logs collected under ambient and pumping conditions both show only a slight inflection at a depth of about $425 \mathrm{ft}$ bls; the fluid-conductivity log collected under ambient conditions also shows a small inflection near $60 \mathrm{ft}$ bls.

The flow log collected under ambient conditions indicates downward flow at depths below $62 \mathrm{ft}$ bls, with downward flow increasing the most between depths of 62 and $68 \mathrm{ft}$ bls and continued to increase to a depth of $124 \mathrm{ft}$ bls; downward flow then starts to decrease, decreasing the most between depths of 185 and $205 \mathrm{ft}$ bls and continuing to decrease substantially below the depth of $322 \mathrm{ft}$ bls $\mathrm{ft}$ bls (table 17). Small rates of downward flow were measured from 380 to $545 \mathrm{ft}$ bls under ambient conditions (table 17). This pattern indicates that water probably enters the borehole through the fractures near the bottom of the casing at 59 to $68 \mathrm{ft}$ bls, then flows down to exit fractures near 130, 195, 230-300, 340, 380, 400, and possibly below $545 \mathrm{ft}$ bls under ambient conditions at the time of logging. The flow log collected under pumping conditions (table 17) indicates that the fractures at depths above $68 \mathrm{ft} \mathrm{bls}$ appear to be the most hydraulically active water-bearing zones in the well.

The borehole video log, collected by USGS on October 31, 2018, when the water level was $15.4 \mathrm{ft}$ bls, showed numerous horizontal and vertical fractures throughout the borehole and that the bottom of casing is $18.5 \mathrm{ft} \mathrm{bls}$. Probable water-bearing zones were noted for fractures at about 58.3, 63.5, 110.1, 191.2, and $333.9 \mathrm{ft}$ bls. Other possible water-bearing fractures were noted at 73.2-80.6, 92.2-94.5, $105.7,116.7,129.6,143.5,259.7,302.3,309.2$, and $371 \mathrm{ft}$ bls. Below $365 \mathrm{ft}$ bls, haze in the water column increased with depth. Near $405 \mathrm{ft}$ bls, visibility decreased to zero and video $\log$ collection was ceased. Turbulence with water injecting into the borehole was observed near fractures at about 63.5 $\mathrm{ft}$ bls and possibly near the bottom of casing at $58.3 \mathrm{ft}$ bls. Possible turbulence was also noted near fractures at about $110.1 \mathrm{ft}$ bls. Video-log images for selected fractures or openings in well BK-3070 are shown in figure 32.

\section{BK-3071 (HN-121)}

Well BK-3071 is a new monitor well (HN-121) drilled by the Navy on the former NAWC Warminster base (figs. 1 and 3) that was logged and subsequently tested by USGS using straddle packers to isolate discrete intervals for hydraulic characterization and sampling in 2018 (Senior and others, 2020) before being reconstructed in 2019. The well was initially constructed with a 6-in. diameter casing to a depth of about 20 $\mathrm{ft}$ bls and below that casing was a 6-in. diameter open hole to a reported depth of $600 \mathrm{ft}$ bls, although at the time of logging 
$\boldsymbol{A}$

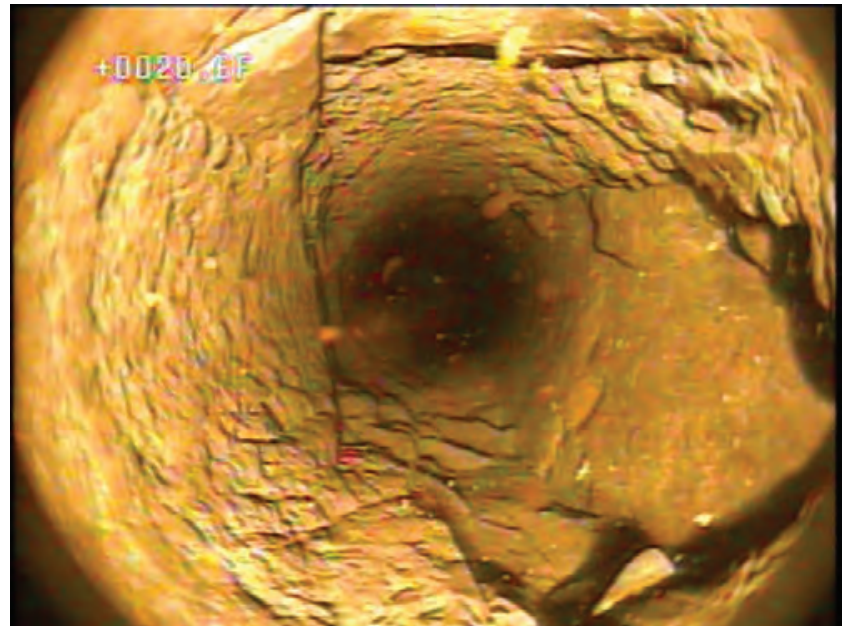

B

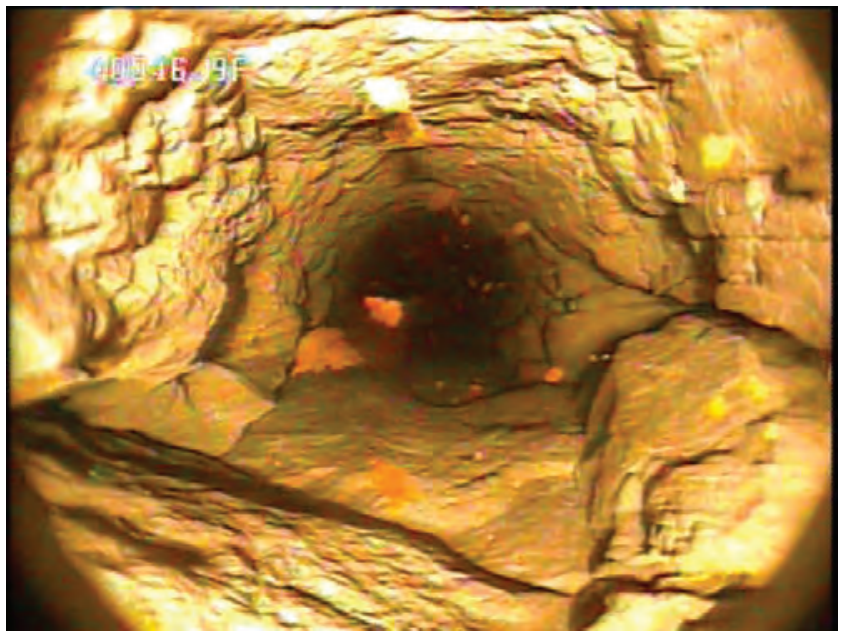

C

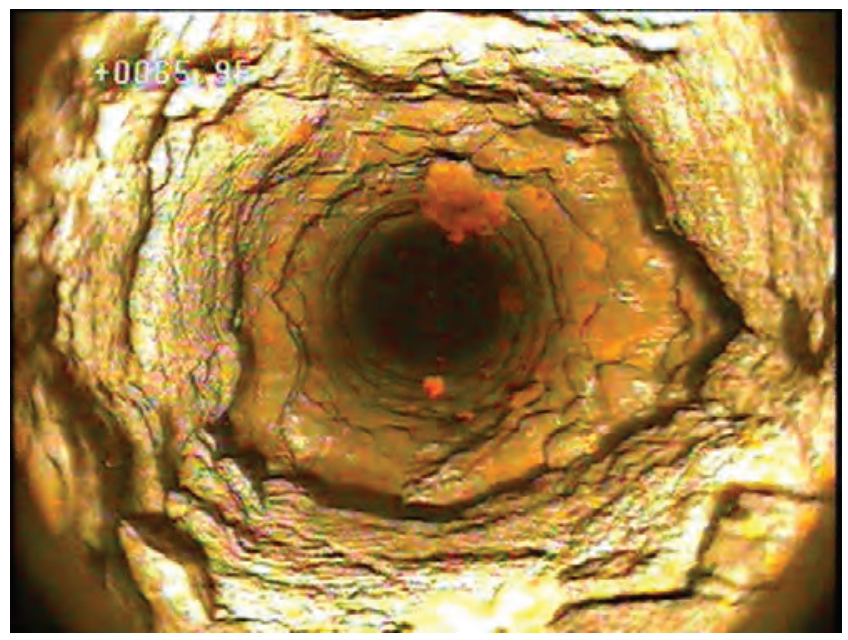

D

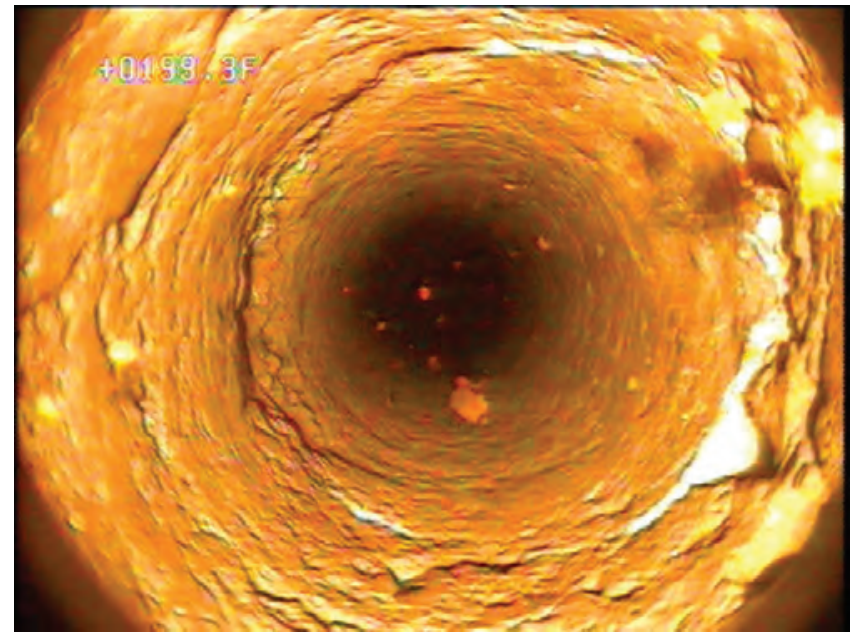

$E$

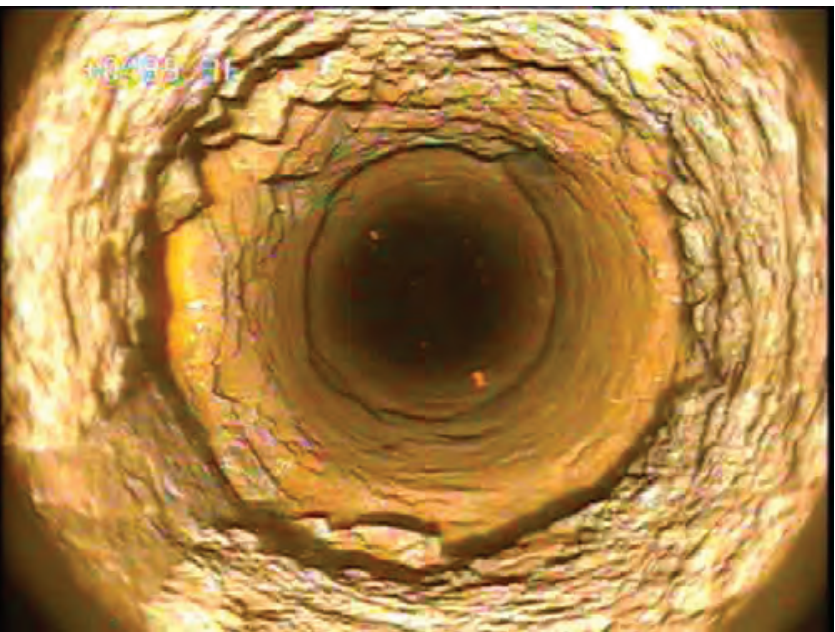

$\boldsymbol{F}$

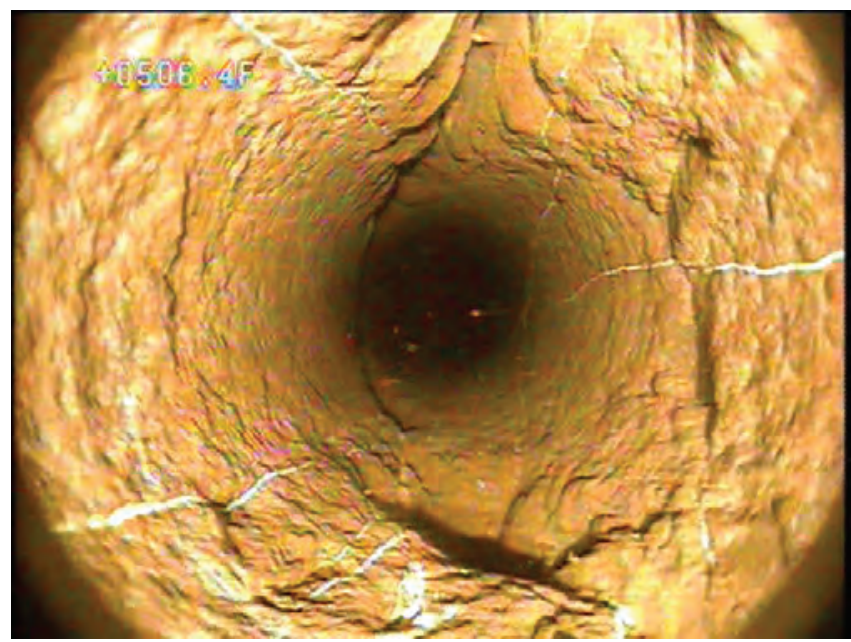

Figure 29. Still images from borehole video log of well BK-3068 (HN-117) at $A, 20.4$ feet below land surface (ft bls) showing high-angle fractures below bottom casing, $B, 46.9 \mathrm{ft}$ bls showing vertical fractures, $C, 65.9 \mathrm{ft}$ bls showing bedding- and fracture-plane openings, $D$, $199.3 \mathrm{ft}$ bls showing low-angle opening where turbulence was observed, $E, 499.6 \mathrm{ft}$ bls showing bedding-plane openings, and $F, 506.9 \mathrm{ft}$ bls showing high-angle openings, Video log collected by U.S. Geological Survey in well BK-3068, Warminster Township, Bucks County, Pennsylvania, August 28, 2018. 

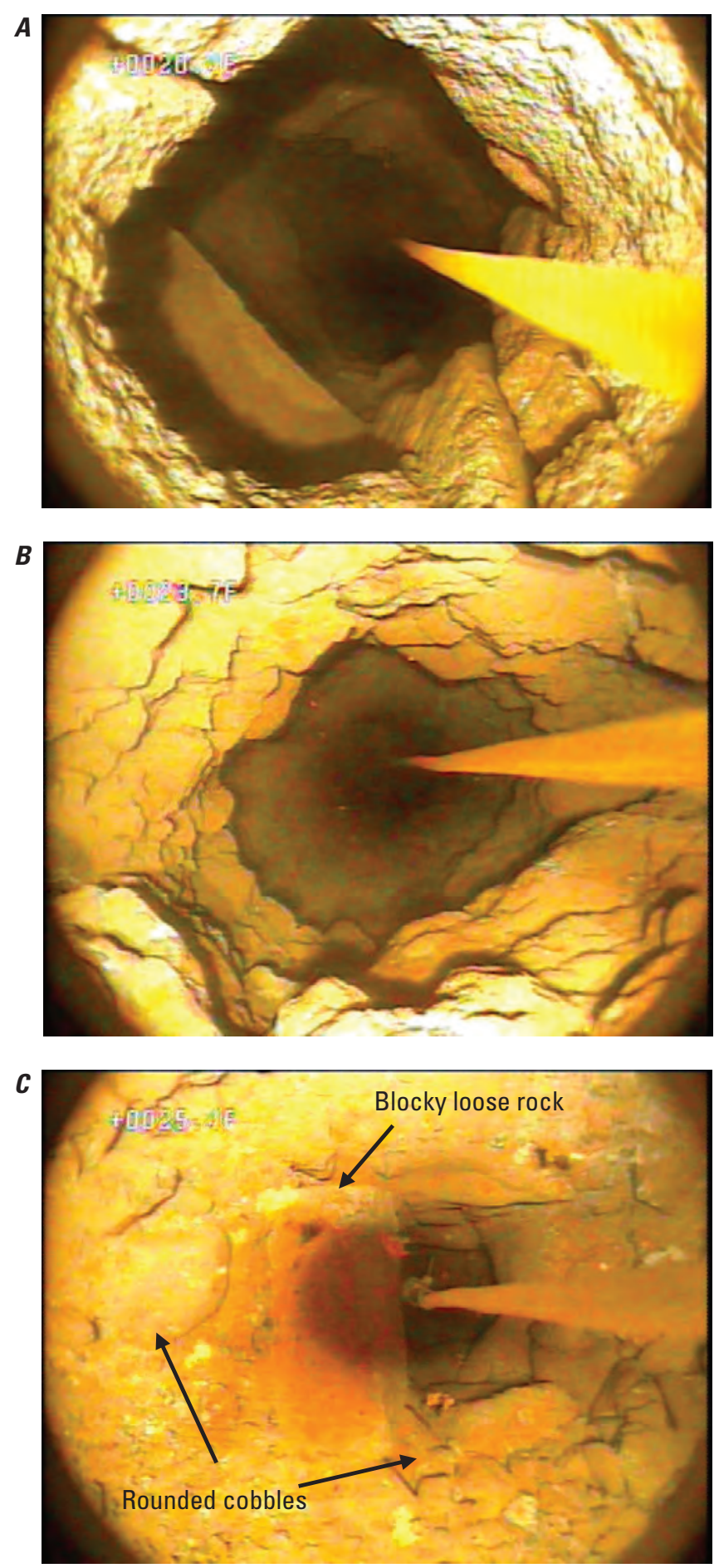

Figure 30. Still images from borehole video log of well BK-3069 (HN-120l) at $A, 20.4$ feet below land surface (ft bls) showing high-angle fractures just above large opening in borehole, $B$, $23.7 \mathrm{ft}$ bls showing extensive openings possibly enhanced by dissolution, and $C, 25.4 \mathrm{ft}$ bls showing rounded cobbles and blocky loose rock in large void just above narrowing of borehole to 6 inch diameter hole. Cable in center of image is for a transducer suspended in well. Video log collected by U.S. Geological Survey in well BK-3069, Warminster Township, Bucks County, Pennsylvania, November 7, 2018. was only open to about $415 \mathrm{ft}$ bls (table 2) because of collapse below that depth. The depth to ambient water level at the time of logging was about $11.6 \mathrm{ft}$ bls.

The caliper and ATV logs show numerous fractures throughout the borehole, with the largest openings at depths in the range of 20 to $115 \mathrm{ft}$ bls and near 160, 290, 375, and $410 \mathrm{ft}$ bls (fig. 33). The fluid-temperature logs collected under ambient conditions show small inflections at depths of about 30 , 95,305 , and $345 \mathrm{ft}$ bls that could be used to identify depth of water-bearing fractures. The fluid-conductivity logs collected under ambient and pumping conditions show only a slight inflection near $30 \mathrm{ft}$ bls.

The flow log collected under ambient conditions indicates downward flow at depths below $34 \mathrm{ft}$ bls, with downward flow increasing between depths of 34 and $110 \mathrm{ft}$ bls, then decreasing between depths of 110 and $132 \mathrm{ft}$ bls, remaining more or less constant from 132 to $238 \mathrm{ft}$ bls before another slight decrease in downward flow between 256 and $360 \mathrm{ft}$ bls, before decreasing again at 380 and $410 \mathrm{ft}$ bls (table 18). This pattern indicates that water probably enters the borehole through the fractures near the bottom of casing at 20 to $34 \mathrm{ft}$ bls and also through several fractures in the range from 34 to $110 \mathrm{ft} \mathrm{bls,}$ then travels down to possibly exit fractures near 250, 375, and below $410 \mathrm{ft}$ bls under ambient conditions at the time of logging. The flow log collected under pumping conditions (table 18) indicated that the fractures at depths above $34 \mathrm{ft} \mathrm{bls}$ appear to be the most hydraulically active water-bearing zones in the well. Downward flow rates were greater when measured under pumping conditions than under ambient conditions, suggesting changes in aquifer conditions related to possible changes in nearby pumping or to other unknown factors. The closest known deep (600 ft) active production well is about $4,400 \mathrm{ft}$ approximately along strike to the northeast of well BK-3070.

The borehole video log, collected by the USGS on November 6, 2018, when the water level was $11.4 \mathrm{ft}$ bls, showed some horizontal and numerous vertical fractures throughout the borehole. Probable water-bearing zones were noted for fractures or openings at about 19.2-37.4, 69.4, $251.5,283.3-289.8,367.5-372$ and $411 \mathrm{ft}$ bls. Other possible water-bearing fractures were noted at 80.8-82.8, 83.6, 89.3, $108.3,146,154.1-157.3,160.7,201.8,216$, and $300.5 \mathrm{ft}$ bls. Below about $411 \mathrm{ft}$ bls, the borehole appeared to be collapsed and video log collection was ceased. Video-log images for selected fractures or openings in well BK-3071 are shown in figure 34 .

\section{Discussion of Log Lithology, Fracture Orientation, Borehole Deviation, and Borehole-flow Directions}

The lithology of aquifer intervals penetrated by the wells as shown on optical televiewer, gamma, and resistivity logs appears to be alternating sequences of light-colored, relatively coarser-grained sandstones (lower gamma, higher resistivity) 


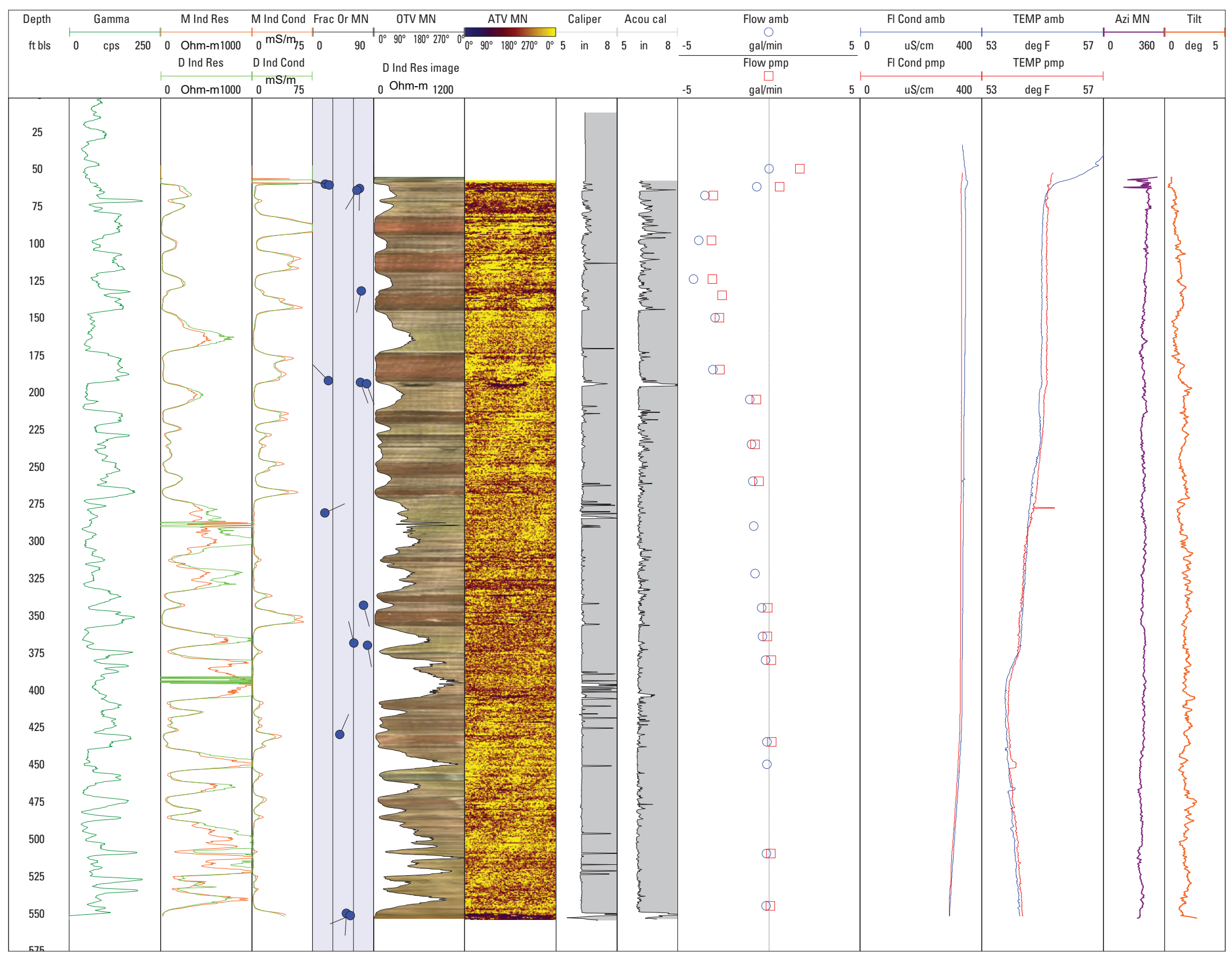

Figure 31. Geophysical logs collected by U.S. Geological Survey in well BK-3070 (HN-120D), Warminster Township, Bucks County, Pennsylvania, 0ctober 31, 2018. See table 1 for explanation of abbreviations. 
Table 17. Borehole flow-measurements collected by U.S. Geological Survey in well BK-3070 (HN-120D), Warminster Township, Bucks County, Pennsylvania, October 31, 2018. Stationary measurements made using an electromagnetic flow meter under ambient and pumping conditions; negative values indicate downward flow and positive values indicate upward flow. Flow values reported in the table reflect corrections to raw measurements based on zero flow in casing under ambient conditions and known flow in casing under pumping conditions.

[ft, feet; bls, below land surface; corr, corrected value; gal/min, gallons per minute; amb, ambient conditions; pmp, pumping conditions; --, no data]

\begin{tabular}{|c|c|c|c|}
\hline \multicolumn{2}{|c|}{ Ambient conditions } & \multicolumn{2}{|c|}{ Pumping conditions } \\
\hline Depth (ft bls) & $\begin{array}{c}\text { Flow amb1, corr } \\
\text { (gal/min) }\end{array}$ & Depth (ft bls) & $\begin{array}{c}\text { Flow pmp2, corr } \\
\text { (gal/min) }\end{array}$ \\
\hline 50 & 0.00 & 50 & 1.70 \\
\hline 62 & -0.66 & 62 & 0.58 \\
\hline 68 & -3.51 & 68 & -3.06 \\
\hline 98 & -3.85 & 98 & -3.15 \\
\hline 124 & -4.12 & 124 & -3.10 \\
\hline 135 & -- & 135 & -2.57 \\
\hline 150 & -2.95 & 150 & -2.71 \\
\hline 185 & -3.08 & 185 & -2.69 \\
\hline 205 & -1.04 & 205 & -0.68 \\
\hline 235 & -0.95 & 235 & -0.75 \\
\hline 260 & -0.88 & 260 & -0.54 \\
\hline 290 & -0.82 & 290 & -- \\
\hline 322 & -0.77 & 322 & -- \\
\hline 345 & -0.40 & 345 & -0.07 \\
\hline 364 & -0.36 & 364 & -0.07 \\
\hline 380 & -0.18 & 380 & 0.12 \\
\hline 435 & -0.12 & 435 & 0.15 \\
\hline 450 & -0.12 & 450 & -- \\
\hline 510 & -0.14 & 510 & 0.11 \\
\hline 545 & -0.15 & 545 & 0.08 \\
\hline
\end{tabular}

${ }^{1}$ Static water level was $15.44 \mathrm{ft}$ bls; ambient flow measured starting at 08:55 on October 31, 2018.

2Pumping rate $1.8 \mathrm{gal} / \mathrm{min}$; flow measured starting at 11:52 on October 31 , 2018; drawdown $0.2 \mathrm{ft}$.
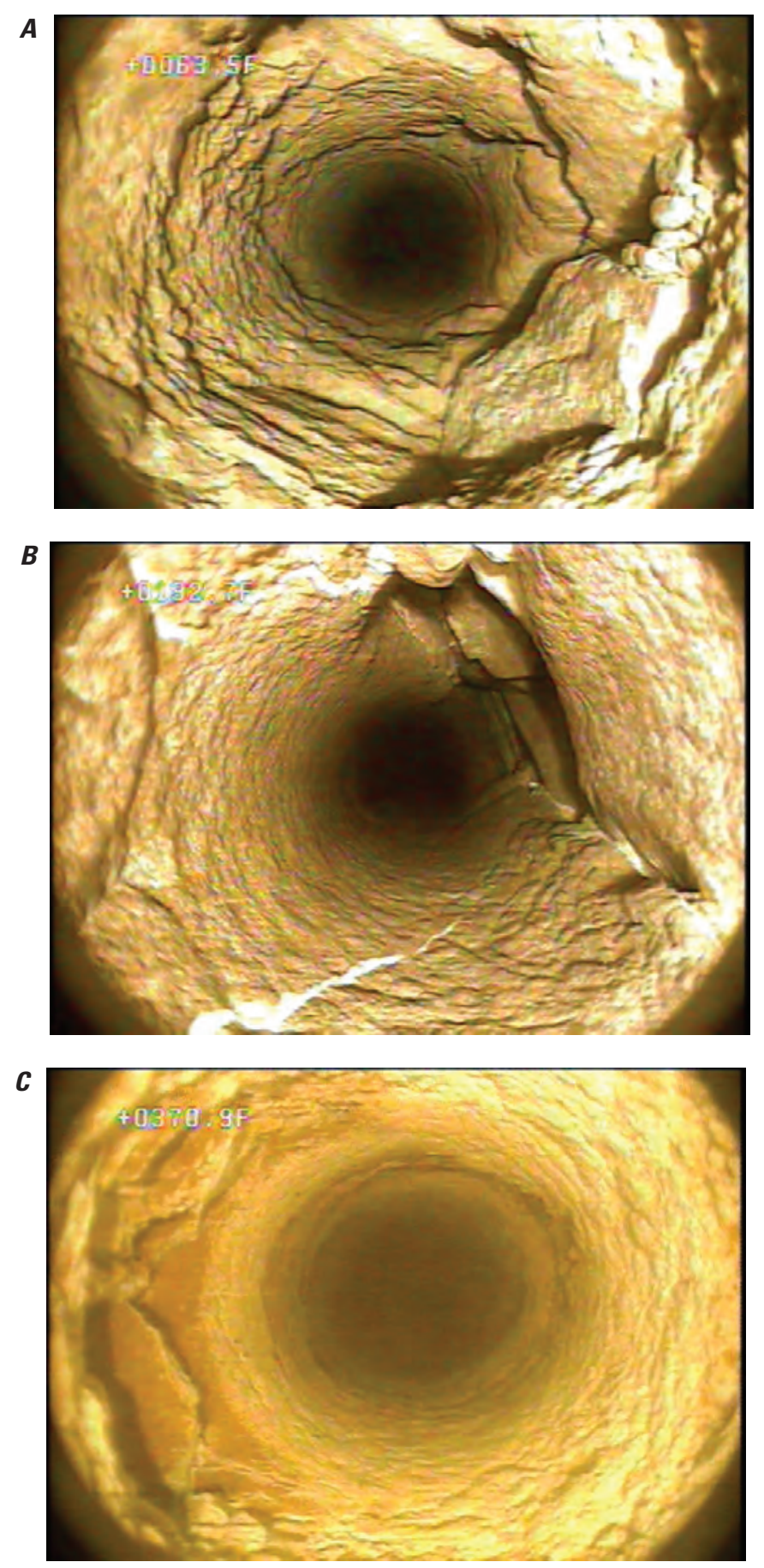

Figure 32. Still images from borehole video log of well BK-3070 (HN-120D) at $A, 63.5$ feet below land surface (ft bls) showing high-angle fractures and bedding-plane opening, $B, 192.7$ $\mathrm{ft}$ bls showing vertical fractures, and $C, 370.9 \mathrm{ft}$ bls showing bedding-plane openings and decreased visibility in borehole related to decreased vertical borehole flow. Video log collected by U.S. Geological Survey in well BK-3070, Warminster Township, Bucks County, Pennsylvania, October 31, 2018. 


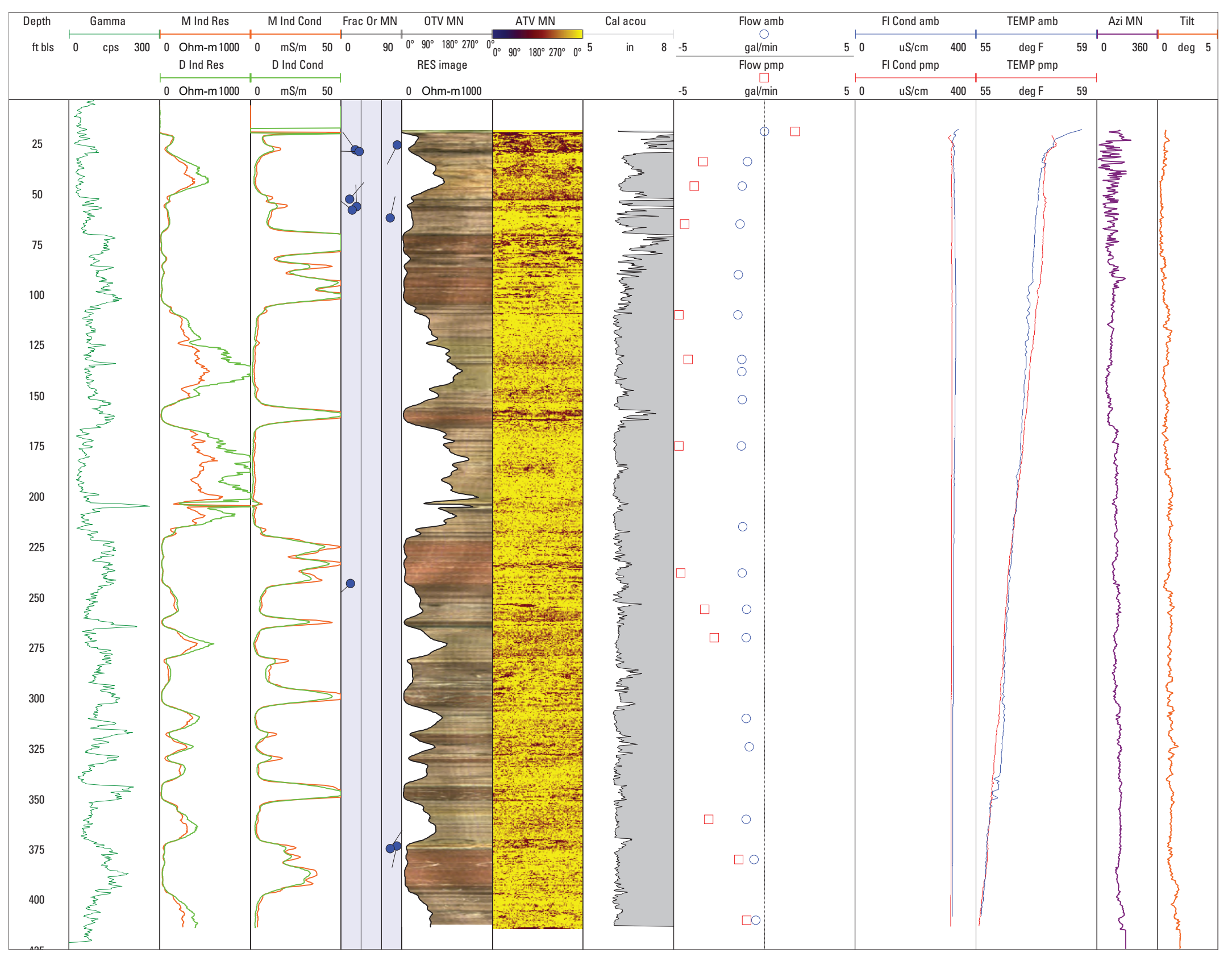

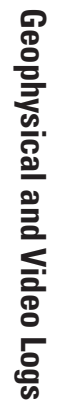

Figure 33. Geophysical logs collected by U.S. Geological Survey in well BK-3071 (HN-121), Warminster Township, Bucks County, Pennsylvania, November 1, 2018. See table 1 for explanation of abbreviations. 
Table 18. Borehole flow-measurements collected by U.S. Geological Survey in well BK-3071 (HN-121), Warminster Township, Bucks County, Pennsylvania, November 1, 2018. Stationary measurements made using an electromagnetic flow meter under ambient and pumping conditions; negative values indicate downward flow and positive values indicate upward flow. Flow values reported in the table reflect corrections to raw measurements based on zero flow in casing under ambient conditions and known flow in casing under pumping conditions.

[ft, feet; bls, below land surface; corr, corrected value; gal/min, gallons per minute; amb, ambient conditions; pmp, pumping conditions; --, no data]

\begin{tabular}{lccc}
\hline & Ambient conditions & & Pumping conditions \\
\hline Depth (ft bls) & Flow amb', corr (gal/min) & Depth (ft bls) & Flow pmp2, corr (gal/min) \\
\hline 19 & 0.00 & 19 & 1.70 \\
34 & -0.94 & 34 & -3.39 \\
46 & -1.21 & 46 & -3.87 \\
65 & -1.33 & 65 & -4.41 \\
90 & -1.44 & 90 & -- \\
110 & -1.46 & 110 & -4.70 \\
132 & -1.24 & 132 & -4.19 \\
138 & -1.25 & 138 & -- \\
152 & -1.22 & 152 & -- \\
175 & -1.27 & 175 & -4.71 \\
215 & -1.18 & 215 & -- \\
238 & -1.21 & 238 & -4.61 \\
256 & -0.99 & 256 & -3.28 \\
270 & -1.01 & 270 & -2.76 \\
310 & -1.00 & 310 & -- \\
324 & -0.83 & 324 & -- \\
360 & -1.00 & 360 & -3.06 \\
380 & -0.56 & 380 & -1.42 \\
410 & -0.47 & 410 & -0.98 \\
\hline
\end{tabular}

${ }^{1}$ Ambient flow measured starting at 08:55 on November 1, 2018; static water level is $11.59 \mathrm{ft}$ bls at 07:56.

2Pumping rate $1.7 \mathrm{gal} / \mathrm{min}$; static water level is $11.60 \mathrm{ft}$ bls at 08:57 prior to start of pumping at 09:10 on November 1, 2018; water level is $11.65 \mathrm{ft}$ bls at 10:24 and end of pumping; drawdown $0.5 \mathrm{ft}$.

and darker finer-grained sandstones, siltstones, or shales (higher gamma, lower resistivity). Thicknesses of the coarsergrained sandstone layers generally are greater than thicknesses of the finer-grained layers.

Most of the wells had water-bearing fractures throughout the depth of the open boreholes. The six new deep wells drilled in 2018 on the former NAWC Warminster base and many of the other existing wells had water-bearing fractures near the bottom of the casing (typically about 20 and as deep as $60 \mathrm{ft}$ bls) that were among the most productive in each borehole. At least four of the six new deep wells drilled in 2018 on the former NAWC Warminster base appear to have active water-bearing fractures at depths greater than $500 \mathrm{ft}$ bls, whereas the remaining two wells had water-bearing fractures near $400 \mathrm{ft}$ bls and were either collapsed [BK-3071 (HN-121)] or nonproductive [BK-3070 (HN-120D)] below that depth.
High-angle fractures in relatively coarser-grained, lighter colored sandstone and associated with probable water-bearing zones are more common in some wells drilled on the former NAWC Warminster base than in other wells logged as part of this investigation. The wells with the most high-angle probable water-bearing fractures include BK-962 (NAWC well 10), BK-3063 (HN-116), and BK-3068 (HN-117) (figs. 4, 22, 28). Other wells on the former NAWC Warminster base with a few high-angle water-bearing fractures include BK-3066 (HN-118), BK-3067 (HN-119), BK-3070 (HN-120), and BK-3071 (HN-121) (figs. 24, 26, 31, and 33). The other eight wells logged for this investigation appeared to have waterbearing zones associated predominantly with bedding-plane openings. Bedding-plane or low-angle openings generally are associated with changes in lithology as indicated by natural gamma and formation resistivity logs; these low-angle openings commonly appear to be associated with relatively higher 
$\boldsymbol{A}$

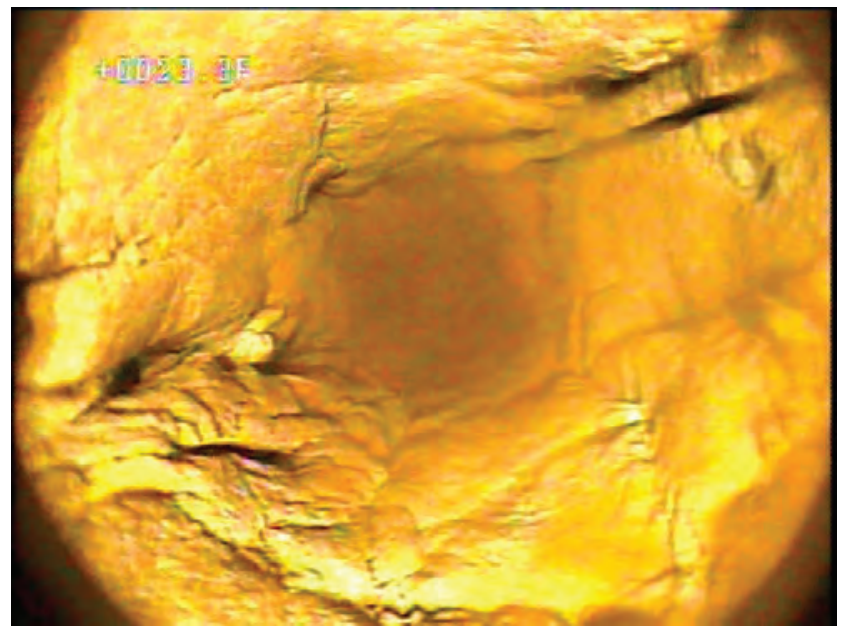

B

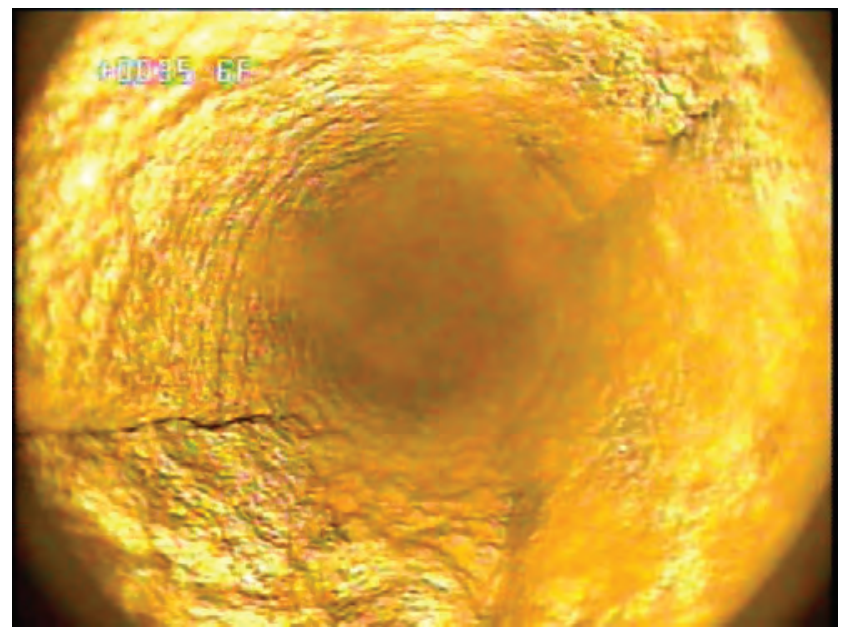

C

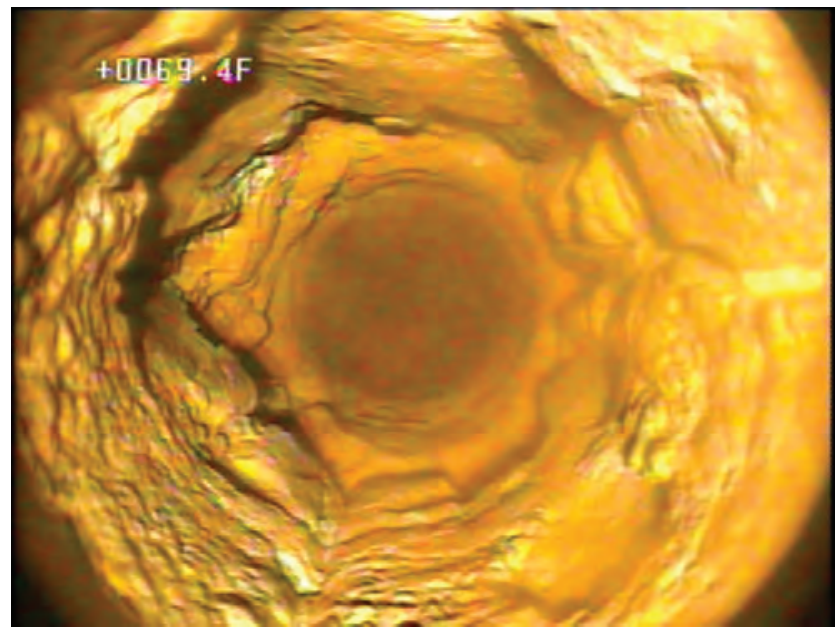

D

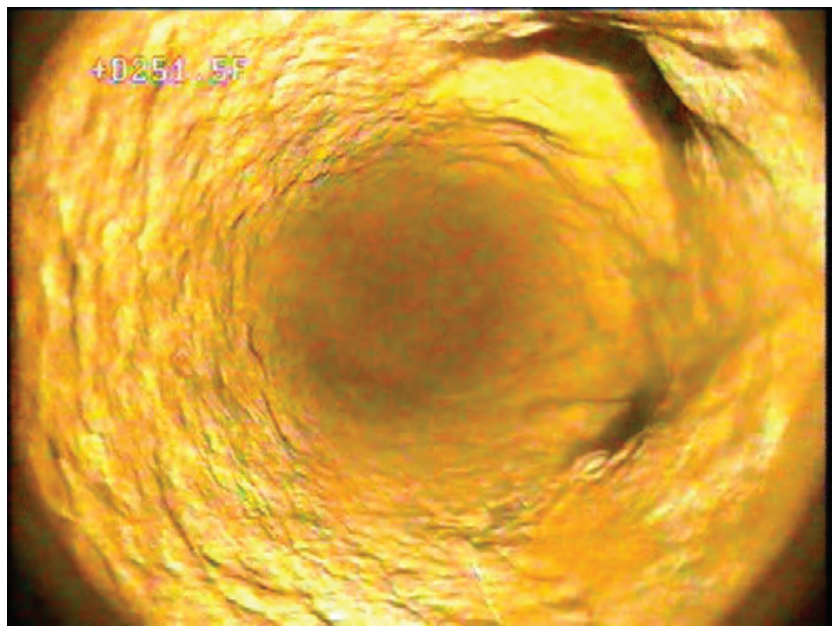

$E$

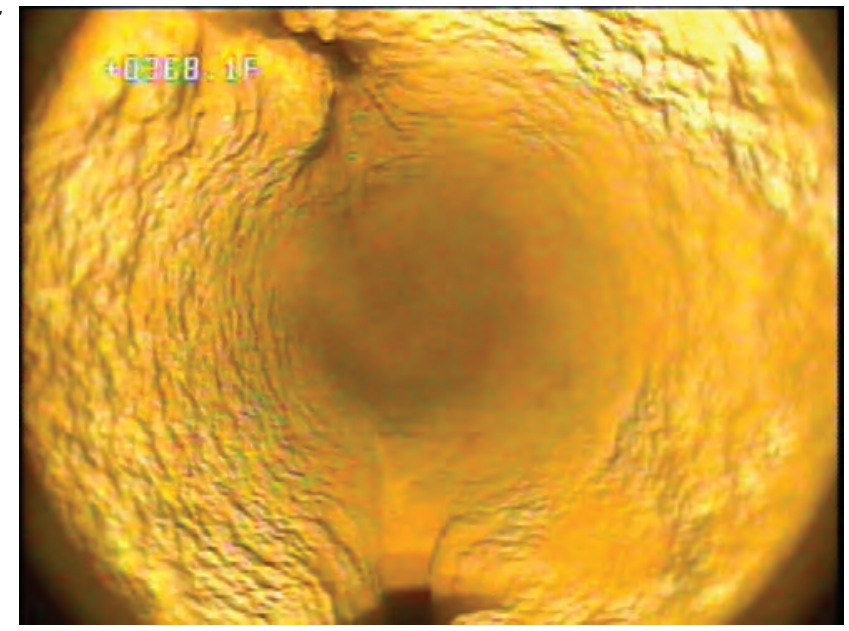

$\boldsymbol{F}$

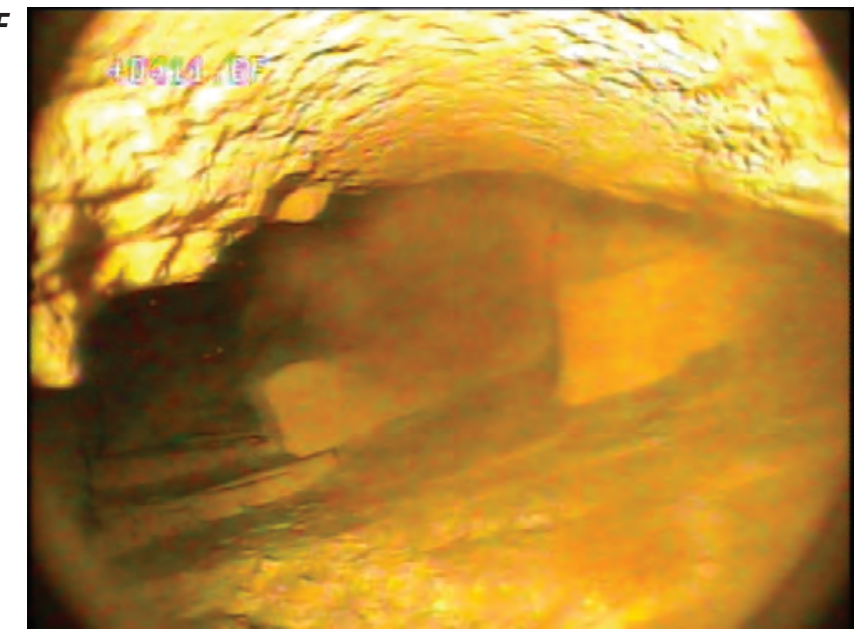

Figure 34. Still images from borehole video log of well BK-3071 (HN-121) at $A, 23.3$ feet below land surface (ft bls) showing high-angle fractures below bottom casing, $B, 35.6 \mathrm{ft}$ bls showing thin vertical fractures, $C, 69.4 \mathrm{ft}$ bls showing bedding- and fracture-plane openings, $D, 251.5 \mathrm{ft}$ bls showing low-angle openings, $E, 368.1 \mathrm{ft}$ bls showing high-angle openings, and $F, 411.6 \mathrm{ft}$ bls showing large void and fractured rocks. Video log collected by U.S. Geological Survey in well BK-3071, Warminster Township, Bucks County, Pennsylvania, November 6, 2018. 
gamma activity and relatively lower resistivity, such as shown in figures 6, 8, and 10 for wells BK-1023, BK-1087, and

BK-1129, respectively.

The orientation of water-bearing fracture openings as determined from interpretation of the ATV logs for principal water-bearing zones are shown relative to magnetic north in tadpole plots as part of log figures for individual wells and with lower hemisphere stereonet plots in appendix 1 (figs. 1.1-1.15) and summarized in table 19. Directions reported relative to magnetic north can be converted to true north by adding 12 degrees 8 minutes (correction for magnetic declination in study area at time of logging). Generally, the high-angle (dip greater than 70 degrees) fracture planes most frequently were oriented either to the southwest or the northeast and the low-angle (dip less than 30 degrees) or bedding-plane openings appeared to be oriented in various directions. Variable types and orientations of lithologic contacts in the Stockton Formation, a fluvial deposit in origin, may be a factor in the apparent lack of a predominant direction for the low-angle openings often associated with these contacts; other factors may include reduced resolution (higher error) in interpreting low-angle features or other geologic controls, such as small faults that could tilt beds at a local scale.

The borehole deviation logs determined using data collected with the ATV logs show that the offset from vertical at the bottom of the wells ranged from 1.9 to as much as 96 $\mathrm{ft}$ for well BK-1023 (well 28) (table 19). As a percentage of well depth, the deviation was less than 4 percent for all wells except BK-1023, where deviation was 16 percent. Although deviation logs were not collected in well BK-1058 (well 27), video logs indicate that well BK-1058 also deviates substantially from vertical.

The direction of borehole deviation may tend to migrate up-dip normal to bedding planes, as has been reported to occur in some cases where bedding dips less than $45^{\circ}$ (McLamore, 1971; Wilson, 1976; Brown and others, 1981). For wells that show borehole deviation to the southeast, the dip of the beds would be to the northwest, as was observed in nearby wells drilled in the Lockatong and Brunswick Formations about 10 mi $(16 \mathrm{~km})$ west of NAWC Warminster (Senior and others, 2008). A dip angle for bedding calculated from the total deviation (shallowest to deepest deviation measurements) does not account for probable non-linear inclination and underestimates actual bedding dip. As the hole is drilled, there is a tendency for increasing degrees of deviation with increasing depth because of greater flexibility in the drill string with additional rods. Thus, the dip angle calculated from the deviation logs is probably shallower than the actual formation dip.

The magnitude and direction (relative to magnetic north) of borehole deviation are shown in polar plots in appendix 2 (figs. 2.1-2.15). The direction of borehole deviation relative to magnetic north was to the southeast for five wells, BK-962, BK-1023, BK-3063, BK-3068 and BK-3071 figs. $2.1,2.2,2.10,2.13$, and 2.15 , respectively) and to the south or southwest for the remainder (figs. 2.3-2.9, 2.11, 2.12, and 2.14). However, the amount of deviation was relatively small for most wells so that the deviation direction may not have migrated to any extent in a direction normal to bedding, which may partly be related to the lithology and sedimentary characteristics of the Stockton Formation. In the well with the largest deviation, BK-1023 (well 28), the deviation direction is about 134 degrees relative to true north (fig. 2.2) which, if normal to bedding, would correspond to a bedding plane direction (strike) of N. $44^{\circ}$ E. and a NW dip (of as much as approximately 18 degrees at depth), consistent with the range of reported bedding orientation in the area (Rima and others, 1962). The direction of borehole deviation is approximately orthogonal to many of the low-angle/bedding-plane openings (appendix 1) as summarized in table 19.

The borehole flow directions measured under ambient conditions are controlled by vertical hydraulic gradients in the layered fractured-rock aquifer that are affected by hydrogeologic setting and (or) nearby pumping. The deepest wells (greater than $400 \mathrm{ft}$ ) are located at the highest elevations (table 19), where downward flow from shallow zones may be related to the recharge setting. Under ambient conditions, most of the new and existing deep (greater than $400 \mathrm{ft}$ ) wells logged for this study exhibited downward borehole flow. All but one (BK-3063 [HN-116]) of the six new deep (555 to 600-ft) boreholes drilled in 2018 at the former NAWC had predominantly downward flow (fig. 1). Well BK-3063 (HN-116), in an area of shallow (less than $100 \mathrm{ft}$ bls) active pumping, had downward flow at depths greater than about $400 \mathrm{ft}$ bls but upward flow above $200 \mathrm{ft}$ bls (fig. 22; table 13). Under ambient conditions for five of the six new wells drilled in 2018, water entered open boreholes through shallow fractures in the upper portions of the boreholes and flowed down to exit fractures at depths generally near or greater than 400 to $500 \mathrm{ft}$ bls. Cascading water from shallow fractures above the static water level in open boreholes was observed in wells BK-3066 (HN-118) and BK-3067 (HN-119).

Under ambient conditions, most wells less than $400 \mathrm{ft}$ in depth logged for this study had upward flow and were located at relatively lower elevations (table 19). Well BK-1129 (well 36), a 380-ft-deep unused production well, located west of the former NAWC, was flowing and had upward flow from depths of $356 \mathrm{ft}$ bls. Well BK-3063 (HN-116), a 600-ft-deep new monitor well located in the vicinity of active shallow (less than $100 \mathrm{ft}$ ) pumping for groundwater remediation at former NAWC Area A (fig. 3), had both upward flow above $200 \mathrm{ft}$ and downward borehole flow below $400 \mathrm{ft}$. 
Table 19. Summary of borehole deviation logs, directions of borehole flow, land-surface elevations at well heads, and other characteristics for wells logged by U.S. Geological Survey at and near the former Naval Air Warfare Center Warminster during 2017-19, Bucks County, Pennsylvania, listed in increasing magnitude of land-surface elevation at well head.

[WMA, Warminster Municipal Authority; WTWSA, Warwick Township Water and Sewer Authority; NBCMA, Northampton Bucks County Municipal Authority; ft bls, feet below land surface; in., inch; ft, foot; NAVD88, North American Vertical Datum 1988; <, less than; --, no data; ?, indicates uncertainty; N, north; NE, northeast; NW, northwest; E, east; S, south; SE, southeast; SW, southwest]

\begin{tabular}{|c|c|c|c|c|c|c|c|c|c|c|c|c|c|c|}
\hline $\begin{array}{c}\text { USGS } \\
\text { local well } \\
\text { name }\end{array}$ & Owner & $\begin{array}{c}\text { Owner } \\
\text { well } \\
\text { name }\end{array}$ & $\begin{array}{l}\text { Casing } \\
\text { length } \\
\text { (ft bls) }\end{array}$ & $\begin{array}{l}\text { Logged } \\
\text { depth } \\
\text { (ft bls) }\end{array}$ & $\begin{array}{l}\text { Hole } \\
\text { diameter } \\
\text { (in.) }\end{array}$ & $\begin{array}{c}\text { Horizontal } \\
\text { deviation } \\
\text { from } \\
\text { vertical at } \\
\text { bottom of } \\
\log (\mathrm{ft})\end{array}$ & $\begin{array}{l}\text { Horizontal } \\
\text { deviation as } \\
\text { percentage of } \\
\text { well depth }\end{array}$ & $\begin{array}{l}\text { Deviation } \\
\text { from } \\
\text { vertical } \\
\text { (degrees) }\end{array}$ & $\begin{array}{c}\text { Approximate } \\
\text { direction of } \\
\text { deviation } 1\end{array}$ & $\begin{array}{c}\text { General } \\
\text { direction } \\
\text { of } \\
\text { deviation }\end{array}$ & $\begin{array}{c}\text { Dip direction² } \\
\text { of low-angle/ } \\
\text { bedding-plane } \\
\text { water-bearing } \\
\text { opening }\end{array}$ & $\begin{array}{c}\text { Dip direction } \\
\text { of high-angle } \\
\text { water-bearing } \\
\text { opening }\end{array}$ & $\begin{array}{c}\text { Estimated } \\
\text { land-surface } \\
\text { elevation (ft } \\
\text { above NAVD88) }\end{array}$ & $\begin{array}{l}\text { Predominant borehole } \\
\text { flow direction under } \\
\text { ambient conditions }\end{array}$ \\
\hline BK 2698 & WTSA & Well 8 & 60 & 210.5 & 10 & 4.0 & 1.9 & 1.1 & 163 & SE & $\mathrm{S}$ & SW & 210 & Up from $145 \mathrm{ft}$ \\
\hline BK 2861 & WTSA & Well 11 & 83 & 160 & 10 & 1.5 & 0.9 & 0.5 & 205 & SW & $\mathrm{NE}$ & SW & 214 & Up from $144 \mathrm{ft}$ \\
\hline BK 1058 & WMA & Well 27 & 58 & 485 & 8 & -- & -- & -- & -- & -- & -- & -- & 228 & -- \\
\hline BK 2869 & WTSA & Well 9 & 63 & 315 & 10 & 4.5 & 1.4 & 0.8 & 197 & SW & SW & SW,NE & 245 & Slight down \\
\hline BK 2870 & WTSA & Well 10 & 61 & 270 & 10 & 7.1 & 2.6 & 1.5 & 224 & SW & Flat & SW,NE & 247 & Slight up \\
\hline BK 1129 & WMA & Well 36 & 50 & 375 & 12 & 3.9 & 1.0 & 0.6 & 217 & SW & $\begin{array}{l}\text { NW,NE, } \\
\text { SE,SW }\end{array}$ & NW & 265 & Up \\
\hline BK 1087 & WMA & Well 25 & 60 & 400 & 8 & 14.2 & 3.6 & 2.0 & 185 & SW & NW,NE,SE & $\mathrm{N}, \mathrm{SW}$ & 273 & Up from $360 \mathrm{ft}$ \\
\hline BK 3068 & Navy & HN-117 & 19 & 600 & 6 & 6.6 & 1.1 & 0.6 & 134 & $\mathrm{SE}$ & NE,NW,E & SW,NE & 313 & $\begin{array}{l}\text { Down to } 500 \mathrm{ft} \text {; up from } \\
\text { bottom to } 500 \mathrm{ft}\end{array}$ \\
\hline BK 3063 & Navy & HN-116 & 19 & 601 & 6 & 13.5 & 2.2 & 1.3 & 138 & $\mathrm{SE}$ & SW & SW,NE,SE & 313 & $\begin{array}{l}\text { Up above } 200 \mathrm{ft} \text {; down } \\
\text { below } 400 \mathrm{ft}\end{array}$ \\
\hline BK 3070 & Navy & $\mathrm{HN}-120 \mathrm{D}$ & 59 & 555 & 6 & 13.0 & 2.3 & 1.3 & 224 & SW & NW,NE & SW,SE & 327 & Down to $380 \mathrm{ft}$ \\
\hline BK 3062 & NBCMA & Well 15 & 93 & 400 & 10 & 5.7 & 1.4 & 0.8 & 202 & SW & $\mathrm{NE}, \mathrm{E}$ & -- & 343 & $\begin{array}{l}\text { None to slightly up } \\
\text { above } 99 \mathrm{ft} \text {; down (?) } \\
\text { below } 280 \mathrm{ft}\end{array}$ \\
\hline BK 1023 & WMA & Well 28 & 57 & 604 & 8 & 96.5 & 16.0 & 9.2 & 134 & SE & SE,SW & -- & 345 & Down \\
\hline BK 962 & WMA & NAWC10 & 50 & 385 & 8 & 11.5 & 3.0 & 1.7 & 148 & $\mathrm{SE}$ & $\mathrm{N}, \mathrm{NE}, \mathrm{NW}$ & SW, NE & 346 & Up from bottom to $200 \mathrm{ft}$ \\
\hline BK 3066 & Navy & HN-118 & 19 & 602 & 6 & 15.1 & 2.5 & 1.4 & 217 & SW & E,N & SW & 346 & Down \\
\hline BK 3071 & Navy & $\mathrm{HN}-121$ & 20 & 415 & 6 & 6.0 & 1.4 & 0.8 & 128 & SE & NW,NE,SW,E & SW,NE & 352 & Down \\
\hline BK 3067 & Navy & HN-119 & 20 & 602 & 6 & 18.4 & 3.1 & 1.8 & 198 & SW & NE,SE,S & SW,NW & 360 & Down \\
\hline
\end{tabular}

${ }^{1}$ Approximate direction of deviation relative to true north; magnetic declination about -12.13 degrees in study area.

2Estimated predominant direction, relative to magnetic north, of dip for low-angle/bedding-plane or high-angle water-bearing opening as interpreted from acoustic televiewer log and other logs, where low angle is less than 30 degrees and high angle is greater than 70 degrees. 


\section{Summary}

Groundwater is a substantial source of public, domestic, and industrial water supply in areas underlain by the Triassic Stockton Formation, a fractured sandstone aquifer, in southern Montgomery and Bucks Counties, Pennsylvania, where two formerly active military bases are located. The Naval Air Warfare Center (NAWC) Warminster (formerly the Naval Air Development Center, Johnsville) in Warminster and Northampton Townships, Bucks County was active during 1944-96. About 3 miles west of NAWC Warminster, the Naval Air Station Joint Reserve Base (NASJRB) Willow Grove in Horsham Township, Montgomery County was operated by the U.S. Navy (Navy) from 1942 until September 2011, with a portion currently (2020) still active and operated by the Pennsylvania Air National Guard (ANG) and designated Horsham Air Guard Station (HAGS). Previous investigations identified areas of groundwater contaminated by volatile organic compounds (VOCs) at both NAWC Warminster and NASJRB Willow Grove, which subsequently were addressed by remediation.

In summer 2014, through sampling of production wells, groundwater at and near the former NAWC Warminster and former NASJRB Willow Grove was found to be contaminated with perfluorooctanesulfonic acid (PFOS) and perfluorooctanoic acid (PFOA), compounds that may pose a risk to human health if present above certain concentrations in drinking water. PFOS and PFOA are part of a group of compounds more broadly designated per- and polyfluoroalkyl substances (PFAS). Potential sources of PFOS and PFOA in the area include fire-suppressant compounds (fluorinated surfactants in aqueous film forming foams) used on and (or) near these facilities when the bases were operating. Some production wells were shut down in response to the discovery of PFOS and PFOA, while others were restarted with treatment to remove the PFAS compounds. After PFAS was discovered in the area surrounding the bases, the Navy and the ANG have offered nearby residences with private domestic wells that yielded water with PFOS and PFOA concentrations greater than the lifetime health advisory for these compounds in drinking water (U.S. Environmental Protection Agency, 2016) to be connected to public drinking water supplies, and also established a program to monitor PFOS and PFOA concentrations in water from nearby residential wells that have not been connected to public supply.

Management and mitigation of groundwater that is contaminated with PFOS and PFOA on and near the former NAWC Warminster and the nearby Willow Grove NASJRB requires assessment of the sources and distribution of contaminant occurrence. In 2014, the Navy and its contractors began sampling soils, streams, and groundwater water through preliminary remedial investigations.

The U.S. Geological Survey (USGS) collected borehole geophysical and video logs in 15 open-hole wells in Northampton, Warminster, and Warwick Townships, Bucks County, Pennsylvania during 2017-19 to support detailed groundwater investigations by the Navy and its contractors at and near the former NAWC Warminster, where groundwater contamination PFAS had become a concern since 2014 . The geophysical and video logs were used to characterize the boreholes and identify potential water-bearing fractures for subsequent detailed investigations that included aquiferinterval-isolation tests of discrete water-bearing zones using straddle packers in 13 wells and depth-discrete point sampling in 2 wells. The 15 wells ranged in depth from about 210 to 604 feet (ft) below land surface (bls) and included six new 6-inch diameter wells drilled to initial depths of $600 \mathrm{ft}$ bls on the former NAWC Warminster base property in 2018 and nine 8to 12-inch diameter existing former production or unused test wells. Partial geophysical or video logs also were collected by USGS during 2018 in two other wells that were not included in subsequent detailed investigations. Casing lengths ranged from about 19 to $93 \mathrm{ft}$ bls. The depth to the static water level at the time of logging ranged from about $1.8 \mathrm{ft}$ above land surface in a flowing well to about $55 \mathrm{ft}$ bls.

The lithology of aquifer intervals intercepted by wells as shown on optical televiewer, gamma, and resistivity logs appears to be alternating sequences of light-colored, relatively coarser-grained sandstones (lower gamma, higher resistivity) and darker, finer-grained sandstones, siltstones, or shales (higher gamma, lower resistivity). Most wells had numerous water-bearing fractures throughout the depth of the open boreholes. High-angle fractures in relatively coarser-grained, lighter colored sandstone and associated with probable waterbearing zones are more common in some wells drilled on the former NAWC Warminster base than in other wells logged as part of this investigation, which had water-bearing zones associated with low-angle or bedding-plane openings. Measured borehole flow was predominantly downward in most of the deepest wells (greater than $400 \mathrm{ft}$ ) commonly located at the highest land-surface elevations, with inflow from fractures at relatively shallower depths and outflow through fractures near or below depths of $500 \mathrm{ft}$ bls. Borehole flow was predominantly upward in most wells less than $400 \mathrm{ft}$ in depth. 


\section{References Cited}

Anderson, J.A., Morin, R.H., Cannia, J.C., and Williams, J.H., 2009, Geophysical log analysis of selected test holes and wells in the High Plains aquifer, Central Platte River basin, Nebraska: U.S. Geological Survey Scientific Investigations Report 2009-5033, 16 p., accessed September 2020 at https://doi.org/10.3133/sir20095003.

Archie, G.E., 1942, The electrical resistivity log as an aid in determining some reservoir characteristics: Transactions of the American Institute of Mining, Metallurgical and Petroleum Engineers, v. 146, no. 01, p. 54-62.

Battelle, 2016, Fourth five-year review for former Naval Air Warfare Center Warminster, Warminster, Pennsylvania: Report N62269.PF.001040 NAWC WARMINSTER 5090.3b prepared for the U.S. Navy Naval Facilities Engineering Command under contract no. N62583-11-D-0515 task order no. 0063 , November 2016, variously paginated, accessed May 12, 2020, at https://www.navfac.navy.mil/niris/MID ATLANTIC/WARMINSTER_NAWC/N62269_001040.pdf.

Battelle, 2017, Final Technical Review Committee meeting minutes regarding meeting held 12 July 2017 NAWC Warminster, PA: Report N62269_001113 NAWC WARMINSTER, PA SSIC 5000-33a, accessed October 20, 2020, at https://www.navfac.navy.mil/niris/MID_ATLANTIC/ WARMINSTER_NAWC/N62269_001113.pdf.

Berg, T.M., Edmunds, W.E., Geyer, A.R., and others, comps., 1980, Geologic map of Pennsylvania (2d ed.): Pennsylvania Geological Survey, 4th Series, Map 1, scale 1:250,000, 2 sheets.

Biella, G., Lozej, A., and Tabacco, I., 1983, Experimental study of some hydrogeophysical properties of unconsolidated porous media: Ground Water, v. 21, no. 6, p. 741-751.

Bird, P.H., 1998, Geohydrology and ground-water quality of Warwick Township, Bucks County, Pennsylvania: U.S. Geological Survey Water-Resources Investigations Report 97-4267, 37 p., accessed April 19, 2019, at https://pubs.er .usgs.gov/publication/wri974267.

Brown, E.T., Green, S.J., and Sinha, K.P., 1981, The influence of rock anisotropy on hole deviation in rotary drilling-A review: International Journal of Rock Mechanics and Mining Sciences, v. 18, no. 5, p. 387-401.

Conger, R.W., 1998, Identification of water-bearing zones by the use of geophysical logs and borehole television surveys, collected February to September 1997, at the Former Naval Air Warfare Center, Warminster, Bucks County, Pennsylvania: U.S. Geological Survey Open-File Report 98-86, 26 p., accessed September 2020 at https://doi.org/ $10.3133 /$ ofr 9886 .
Conger, R.W., and Bird, P.H., 1999, Identification of waterbearing fractures by the use of geophysical logs, May to July 1998, former Naval Air Warfare Center, Bucks County, Pennsylvania: U.S. Geological Survey Open-File Report 99-215, 27 p., accessed September 2020 at https://doi.org/ 10.3133/ofr99215.

Goode, D.J., and Senior, L.A., 2020, Groundwater withdrawals and regional flow paths at and near Willow Grove and Warminster, Pennsylvania-Data compilation and preliminary simulations for conditions in 1999, 2010, 2013, 2016, and 2017: U.S. Geological Survey Open-File Report 2019-1137, 127 p., accessed March 10, 2020, at https://doi.org/10.3133/ofr20191137.

Greenman, D.W., 1955, Groundwater resources of Bucks County, Pennsylvania: Pennsylvania Geological Survey, 4th Series, Bulletin W11, 66 p., 1 plate., accessed September 2020 at http://elibrary.dc nr.pa.gov/GetDocument?docId=1751882\&DocName=W11 _GWRes_BucksCo.

Hess, A.E., 1982, A heat-pulse flowmeter for measuring low velocities in boreholes: U.S. Geological Survey Open-File Report 82-699, 44 p.

Keys, W.S., 1990, Borehole geophysics applied to groundwater investigations: U.S. Geological Survey Techniques of Water-Resources Investigations, book 2, chap. E2, 150 p., accessed March 10, 2020, at https: //doi.org/10.3133/twri02E2.

Kwader, T., 1985, Estimating aquifer permeability from formation resistivity factors: Ground Water, v. 23, no. 6, p. 762-766.

Leidos, 2018, Final groundwater monitoring report for the perfluorinated compound facility investigation at the Horsham Air Guard Station (111th Attack Wing) Horsham, Pennsylvania: Report prepared for Air National Guard Restoration Branch under contract no. W9133L-14-D-0007 delivery order no. 0005, variously paginated, accessed February 2021 at https://ar.afcec-cloud.af.mil/Search.aspx.

Longwill, S.M., and Wood, C.R., 1965, Ground-water resources of the Brunswick Formation in Montgomery and Berks Counties, Pennsylvania: Pennsylvania Geological Survey, 4th Series, Bulletin W22, 59 p., 1 plate., accessed September 2020 at http://elibrary.dc nr.pa.gov/GetDocument?docId=1751893\&DocName=W22 _GWRes_BrunswickFm_Montgomery-BerksCos.

Low, D.J., Hippe, D.J., and Yannacci, D., 2002, Geohydrology of southeastern Pennsylvania: U.S. Geological Survey Water-Resources Investigation Report 2002-4166, 347 p., accessed September 2020 at https: //doi.org/10.3133/wri004166. 
Lyttle, P.T., and Epstein, J.B., 1987, Geologic map of the Newark 1 degree x 2 degrees quadrangle, New Jersey, Pennsylvania and New York: U.S. Geological Survey Miscellaneous Investigations Map I-1715, scale 1:250,000, accessed March 10, 2020, at https://doi.org/10.3133/i 1715. [Also available at https://ngmdb.usgs.gov/Prodesc/ proddesc_9892.html.]

McLamore, R.T., 1971, The role of rock strength anisotropy in natural hole deviation: Journal of Petroleum Technology, v. 23 , no. 11, p. 1313-1321.

National Oceanic and Atmospheric Administration, 2020, Magnetic field calculators: National Oceanic and Atmospheric Administration web page, accessed October 20, 2020, at https://www.ngdc.noaa.gov/geomag/ calculators/magcalc.shtml.

Newport, T.G., 1971, Ground-water resources of Montgomery County, Pennsylvania: Pennsylvania Geological Survey, 4th Series, Bulletin W29, 83 p., 2 plates., accessed September 2020 at http://elibrary.dcnr.pa.gov/GetDocume nt?docId=1751900\&DocName=W29_GWRes_MontgomeryCo.

Paillet, F.L., 2000, A field technique for estimating aquifer parameters using flow log data: Ground Water, v. 38, no. 4, p. 510-521.

Paillet, F.L., 2001, Hydraulic head applications of flow logs in the study of heterogeneous aquifers: Ground Water, v. 39, no. 5, p. 667-675.

Penn State Institutes of Energy and Environment, 2015, PAMAP Program $3 \mathrm{~m}$ county mosaic digital elevation model: Pennsylvania Spatial Data Access web page, accessed May 2016 at ftp://ftp.pasda.psu.edu/pub/pasda/ pamap/LidarMosaics/CountyMosaics/county_DEM_3M/.

Pennsylvania Bureau of Topographic and Geologic Survey, 2008a, Physiographic provinces of Pennsylvania: Pennsylvania Spatial Data Access web page, accessed November 14, 2019, at https:/www.pasda.psu.edu/uci/ DataSummary.aspx?dataset $=1153$.

Pennsylvania Bureau of Topographic and Geologic Survey, 2008b, Physiographic sections of Pennsylvania: Pennsylvania Spatial Data Access web page, accessed November 14, 2019, at https://www.pasda.psu.edu/uci/ DataSummary.aspx?dataset $=1154$.

Naval Facilities Engineering Command, 2018, Final second five-year review NAS Willow Grove PA: Report prepared for NAVFAC BRAC Program Management Office East, accessed April 13, 2020, at https:/www.navfac.navy.mil/ niris/MID_ATLANTIC/WILLOW_GROVE_NAS/ N00158_000760.pdf.
Resolution Consultants, 2019, Remedial investigation report Per and Polyfluoroalkyl substances investigations activities Willow Grove, PA Report, volume I Text, Tables, Figures, Appendices A-G: Report N00158_001068 NASJRB WILLOW GROVE, PA SSIC 5000-33 prepared for the U.S. Navy Naval Facilities Engineering Command under contract no. N62470-11-D-8013, September 2019, variously paginated, accessed May 13, 2019, at https://www.navfac .navy.mil/niris/MID_ATLANTIC/WILLOW_GROVE_ NAS/N00158_001068.pdf.

Reynolds, R.J., Anderson, J.A., and Williams, J.H., 2015, Geophysical log analysis of selected test and residential wells at the Shenandoah Road National Superfund Site, East Fishkill, Dutchess County, New York: U.S. Geological Survey Scientific Investigations Report 2014-5228, 30 p., accessed March 10, 2020, at https://d x.doi.org/10.3133/sir20145228.

Rima, D.R., Meisler, H., and Longwill, S., 1962, Geology and hydrology of the Stockton Formation in southeastern Pennsylvania: Pennsylvania Geological Survey, 4th Series, Bulletin W14, 110 p., 4 plates., accessed September 2020 at http://elibrary.denr.pa.gov/GetDocument?docId=1751885\& DocName=W14_Geo-Hydro_StocktonFm_SEPa.

Robinson, G.R., Jr., 1988, Base- and precious-metal mineralization associated with igneous and thermally altered rocks in the Newark, Gettysburg, and Culpepper early Mesozoic basins of New Jersey, Pennsylvania, and Virginia, chap. 26 in Manspeizer, W., ed., Triassic-Jurassic riftingContinental breakup and the origin of the Atlantic Ocean and passive margins: Developments in Geotectonics, v. 22, p. $621-648$.

Rowland, C.J., 1997, Altitude and configuration of the potentiometric surface in Warwick Township, Bucks County, Pennsylvania, September 1994 through May 1995: U.S. Geological Survey Open-File Report 97-554, 1 sheet, accessed September 2020 at https://doi.org/10.3133/ ofr97554.

Schlische, R., 1992, Structural and stratigraphic development of the Newark extensional basin, eastern North AmericaEvidence for the growth of the basin and its bounding structures: Geological Society of America Bulletin, v. 104, no. 10, p. $1246-1263$.

Senior, L.A., Conger, R.W., and Bird, P.H., 2008, Geophysical $\operatorname{logs}$, aquifer tests, and water levels in wells in and near the North Penn Area 7 Superfund site, Upper Gwynedd Township, Montgomery County, Pennsylvania, 2002-2006: U.S. Geological Survey Scientific Investigations Report 2008-5154, 277 p., accessed October 30, 2020, at ht tps://pubs.usgs.gov/sir/2008/5154/sir2008-5154_rev1.pdf. 
Senior, L.A., Zarr, L.F., Olson, L., and Rosman, R., 2020, Water-level data and selected field notes for aquiferinterval-isolation tests at and near the former Naval Air Warfare Center Warminster, Bucks County, Pennsylvania, 2018-19: U.S. Geological Survey data release, accessed February 2021 at https://doi.org/10.5066/P9TC92B5.

Sevon, W.D., 2000, comp., Physiographic provinces of Pennsylvania (4th ed.): Pennsylvania Geological Survey Map 13, scale 1:2,000,000, accessed October 5, 2020, at http://elibrary.denr.pa.gov/GetDocument?docId= 1751225\&DocName=Map13_PhysProvs_Pa.

Sloto, R.A., 1997, Results of borehole geophysical logging and aquifer-isolation tests conducted in the John Wagner and Sons, Inc former production well, Ivyland, Pennsylvania: U.S. Geological Survey Water-Resources Investigations Report 1997-4095, 18 p., accessed September 2020 at https://pubs.er.usgs.gov/publication/ wri974095.

Sloto, R.A., 1998, Results of borehole geophysical logging and hydraulic tests conducted in Area D supply wells, former U.S. Naval Air Warfare Center, Warminster, Pennsylvania: U.S. Geological Survey Water-Resources Investigations Report 98-4129, 47 p., accessed September 2020 at https://doi.org/10.3133/wri984129.

Sloto, R.A., 2008, Interpretation of borehole geophysical logs at Area C, former Naval Air Warfare Center, Warminster Township, Bucks County, Pennsylvania, 2007: U.S. Geological Survey Open-File Report 2008-1207, 20 p., accessed June 2, 2020, at https: //doi.org/10.3133/ofr20081207.

Sloto, R.A., 2010, Changes in groundwater flow and volatile organic compound concentrations at the Fischer and Porter Superfund Site, Warminster Township, Bucks County, Pennsylvania, 1993-2009: U.S. Geological Survey Scientific Investigations Report 2010-5054, 115 p., accessed June 2, 2020, at https: //doi.org/10.3133/sir20105054.

Sloto, R.A., Conger, R.W., and Grazul, K.E., 1998, Geohydrology and distribution of volatile organic compounds in ground water in the Casey Village area, Bucks County, Pennsylvania: U.S. Geological Survey WaterResources Investigations Report 1998-4010, 81 p., accessed September 2020 at https://pubs.er.usgs.gov/publication/ wri984010.

Sloto, R.A., and Davis, D.K., 1982, Effect of urbanization on the water resources of Warminster Township, Bucks County, Pennsylvania: U.S. Geological Survey Water-Resources Investigations Report 82-4010, 78 p., accessed March 28, 2019, at https://pubs.er.usgs.gov/publication/wri824020.
Sloto, R.A., and Grazul, K.E., 1995a, Altitude and configuration of the potentiometric surface, Casey Village, Warminster and Upper Southampton Townships, Bucks County, Pennsylvania, August 3, 1995: U.S. Geological Survey Open-File Report 95-717, 2 maps on 1 sheet, accessed September 2020 at https: //doi.org/10.3133/ofr95717.

Sloto, R.A., Macchioroli, P., and Conger, R.W., 1995b, Geohydrology and vertical distribution of volatile organic compounds in ground water, Fischer and Porter Company Superfund Site, Warminster, Bucks County, Pennsylvania: U.S. Geological Survey Water-Resources Investigations Report 95-4220, 3 plates, accessed December 9, 2020, at https://doi.org/10.3133/wri954220.

Sloto, R.A., Macchioroli, P., and Towle, M.T., 1996, Geohydrology of the Stockton Formation and crosscontamination through open boreholes, Hatboro Borough and Warminster Township, Pennsylvania: U.S. Geological Survey Water-Resources Investigations Report 86-4047, 49 p., 2 plates, accessed March 28, 2019, at https://pubs.er .usgs.gov/publication/wri964047.

TetraTech, 2014, Evaluation of potential source of perfluorinated compounds, former Naval Air Warfare Center Warminster, Pennsylvania: Report prepared for Naval Facilities Engineering Command Mid-Atlantic, Norfolk, Virginia, contract number N62470-08-D-1001, contract task orderWE23, report N62269.AR.001000 NAWC WARMINSTER 5090.3a, November 2014, accessed November 11, 2019, at https://www.navfac.navy.mil/niris/MID ATLANTIC/WARMINSTER_NAWC/N62269_001000.pdf.

Turner-Peterson, C.E., and Smoot, J.P., 1985, New thoughts on facies relationships in the Triassic Stockton and Lockatong Formations, Pennsylvania and New Jersey, in Gilpin, G.R., Jr., and Froehlich, A.J., eds., Proceedings of the second U.S. Geological Survey workshop on the early Mesozoic basins of the Eastern United States: U.S. Geological Survey Circular 946, p. 10-17, accessed September 2020 at https: //doi.org/10.3133/cir946.

U.S. Environmental Protection Agency, 2012, Third Unregulated Contaminant Rule: U.S. Environmental Protection Agency web page, accessed January 31, 2019, at https://www.epa.gov/dwucmr/third-unregulatedcontaminant-monitoring-rule.

U.S. Environmental Protection Agency, 2014, Peer Review of Health Effects Documents for PFOA and PFOS: U.S. Environmental Protection Agency web page, Office of Water EPA - 820-F-14-004, accessed April 10, 2015, at ht tps://water.epa.gov/drink/standards/upload/Peer-Review-ofHealth-Effects-Documents-for-PFOA-and-PFOS-FactsheetFebruary-2014.pdf. 
U.S. Environmental Protection Agency, 2016, FACT SHEET PFOA \& PFOS Drinking Water Health Advisories: U.S. Environmental Protection Agency web page, EPA 800-F-16-003, accessed March 28, 2018, at https://www.epa.gov/sites/production/files/2016-06/ documents/drinkingwaterhealthadvisories_pfoa_pfos updated_5.31.16.pdf.

U.S. Geological Survey, 2005, USGS National Hydrography Dataset (NHD)-High-resolution flowline features: U.S. Geological Survey National Hydrography Dataset, accessed June 3, 2009, at https:/www.pasda.psu.edu/uci/ DataSummary.aspx?dataset $=364$.

U.S. Geological Survey, 2020, GeoLog locator: U.S. Geological Survey web page, accessed March 13, 2020, at https://webapps.usgs.gov/GeoLogLocator/\#!/search.

U.S. Navy, 2016, Naval Air Station Joint Reserve Base Willow Grove PFOA/PFOS Information November 2016: Former Naval Air Station Joint Reserve Base Willow Grove web page, accessed October 20, 2020, at https://www.bracpmo .navy.mil/brac_bases/northeast/reserve_base_willow_grove/ documents.html.

Willard, B., ed., 1959, Geology and mineral resources of Bucks County, Pennsylvania: Pennsylvania Geological Survey, 4th series, Bulletin C9, 243 p., accessed September 2020 at http://elibrary.denr.pa.gov/GetDocume nt?docId=1751044\&DocName=C9 Geo-MinRes_BucksCo.

Williams, J.H., and Johnson, C.D., 2004, Acoustic and optical borehole-wall imaging for fractured-rock aquifer studies: Journal of Applied Geophysics, v. 55, p. 151-159.

Williams, J.H., and Lane, J.W., 1998, Advances in borehole geophysics for groundwater investigations: U.S. Geological Survey Fact Sheet 002-98, 4 p., accessed September 2020 at https://water.usgs.gov/ogw/bgas/publications/FS-002-98/.

Wilson, G.E., 1976, How to drill a usable hole Part 1-Why deviation occurs: World Oil, v. 183, no. 2, p. 40-43.

Young, S.C., and Pearson, H.S., 1995, The electromagnetic borehole flowmeter-Description and application: Ground Water Monitoring and Remediation Review, v. 15, no. 4, p. 138-147. 


\section{Appendix 1. Orientation of Selected Water-bearing Fractures in Wells}




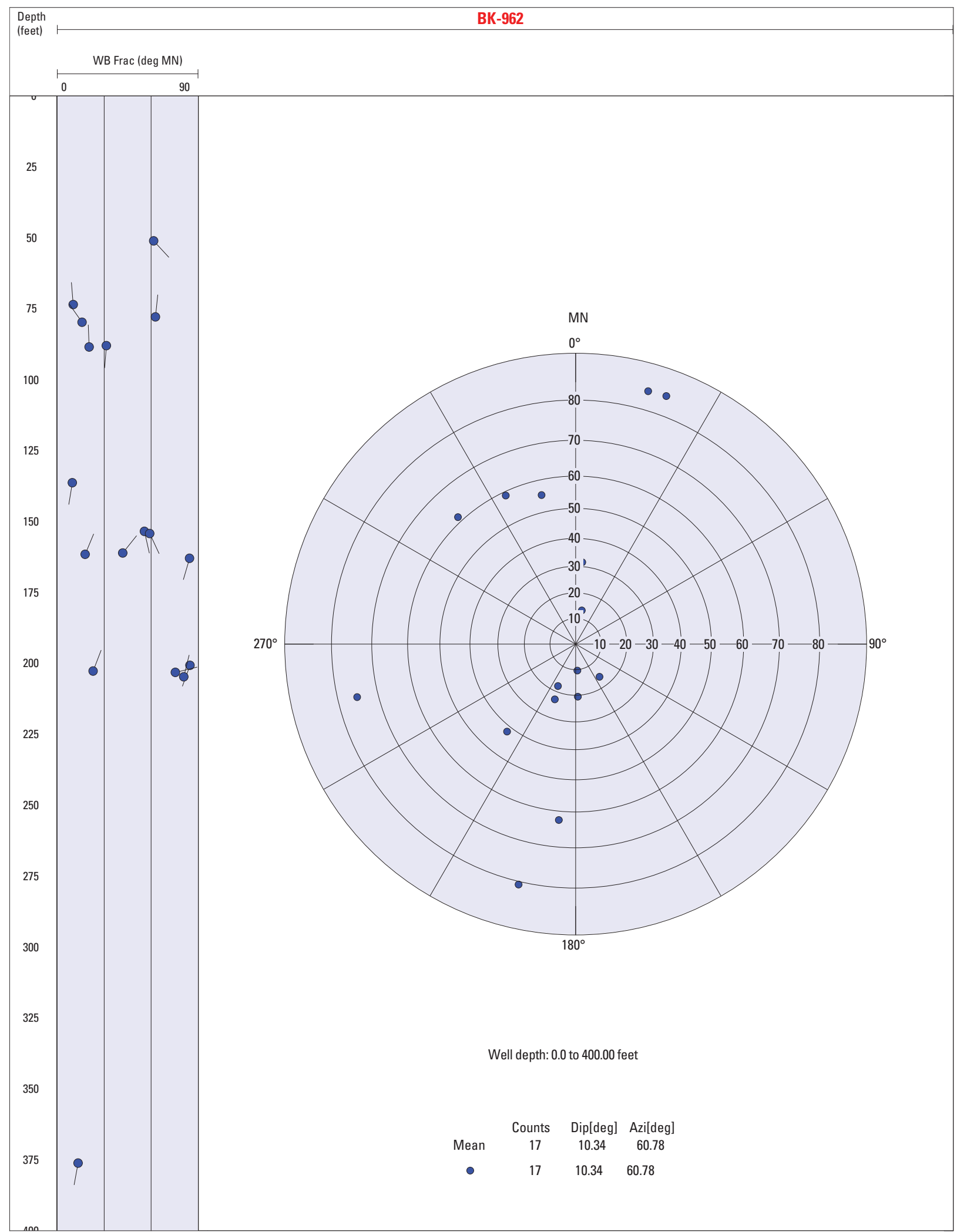

Figure 1.1. Orientation of selected water-bearing (WB) fractures relative to magnetic north (MN) as determined from evaluation of acoustic televiewer and other logs for well BK-962, shown in (left) tadpole plot of fracture azimuth and dip in degrees by depth, and (right) lower hemisphere stereonet depicting projected pole to fracture plane and dip angle with distance from center of plot. Azi, azimuth; deg, degree; frac, fracture; ft, feet. 


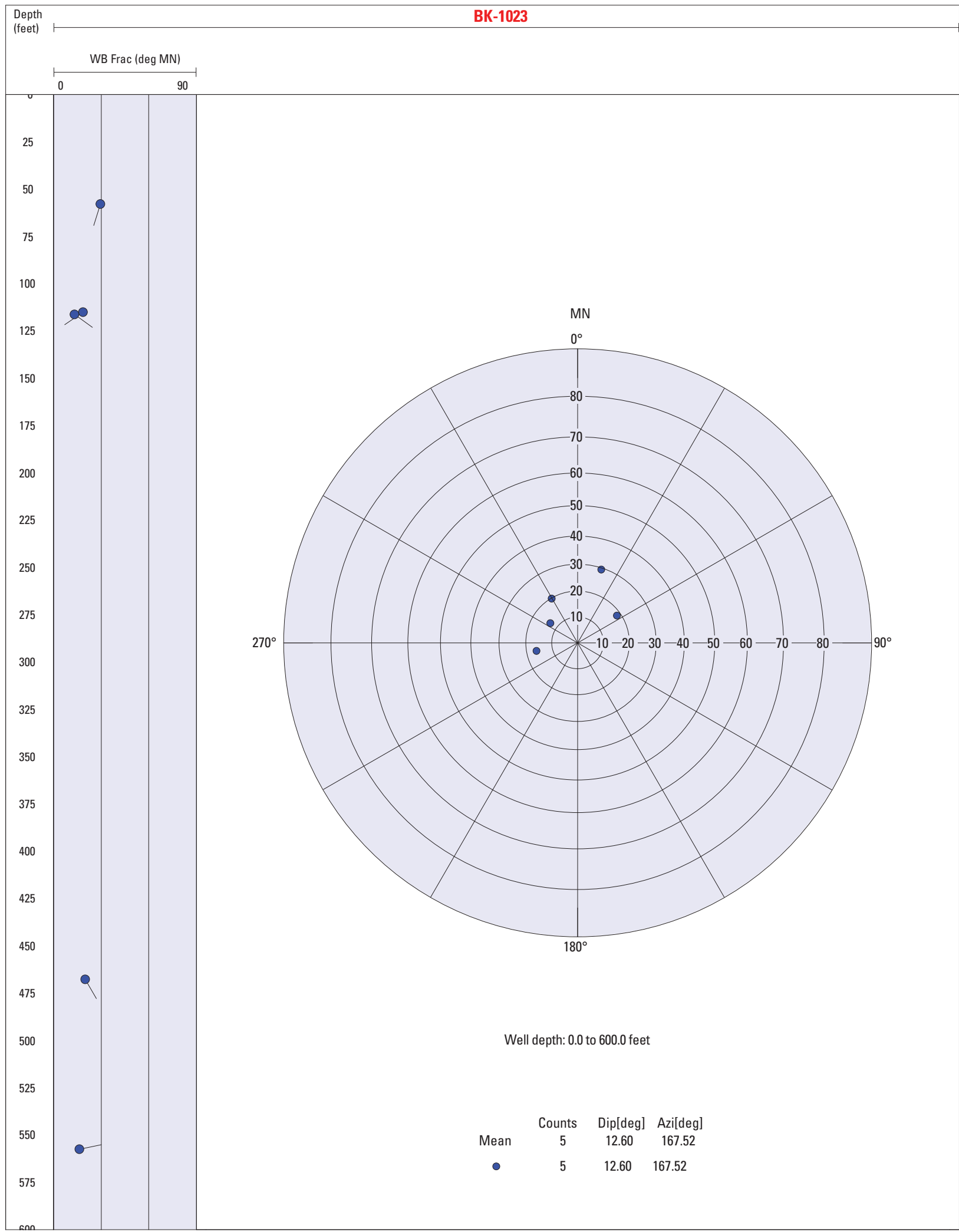

Figure 1.2. Orientation of selected water-bearing (WB) fractures relative to magnetic north (MN) as determined from evaluation of acoustic televiewer and other logs for well BK-1023, shown in (left) tadpole plot of fracture azimuth and dip in degrees by depth, and (right) lower hemisphere stereonet depicting projected pole to fracture plane and dip angle with distance from center of plot. Azi, azimuth; deg, degree; frac, fracture; ft, feet. 


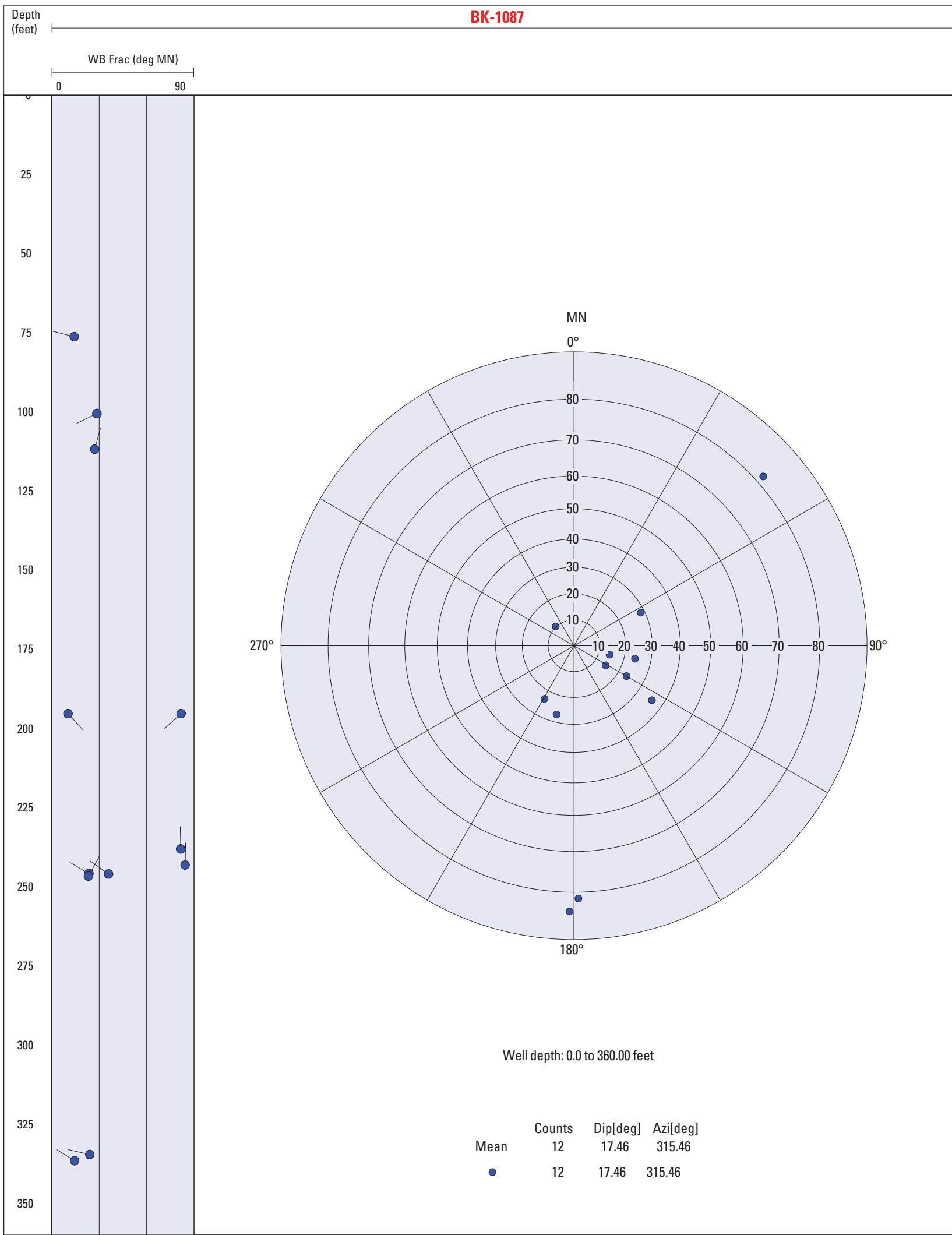

Figure 1.3. Orientation of selected water-bearing (WB) fractures relative to magnetic north (MN) as determined from evaluation of acoustic televiewer and other logs for well BK-1087, shown in (left) tadpole plot of fracture azimuth and dip in degrees by depth, and (right) lower hemisphere stereonet depicting projected pole to fracture plane and dip angle with distance from center of plot. Azi, azimuth; deg, degree; frac, fracture; ft, feet. 


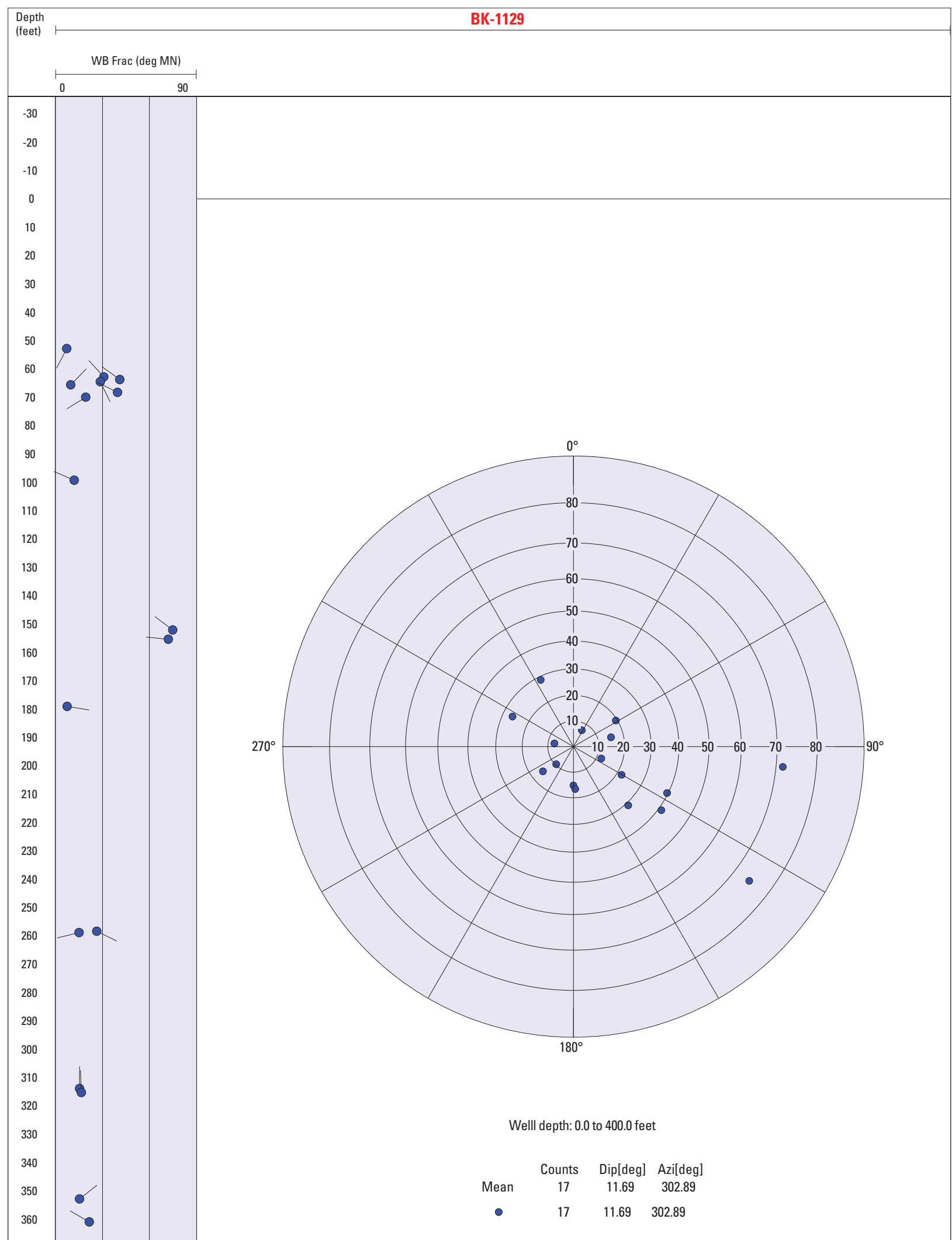

Figure 1.4. Orientation of selected water-bearing (WB) fractures relative to magnetic north (MN) as determined from evaluation of acoustic televiewer and other logs for well BK-1129, shown in (left) tadpole plot of fracture azimuth and dip in degrees by depth, and (right) lower hemisphere stereonet depicting projected pole to fracture plane and dip angle with distance from center of plot. Azi, azimuth; deg, degree; frac, fracture; ft, feet. 


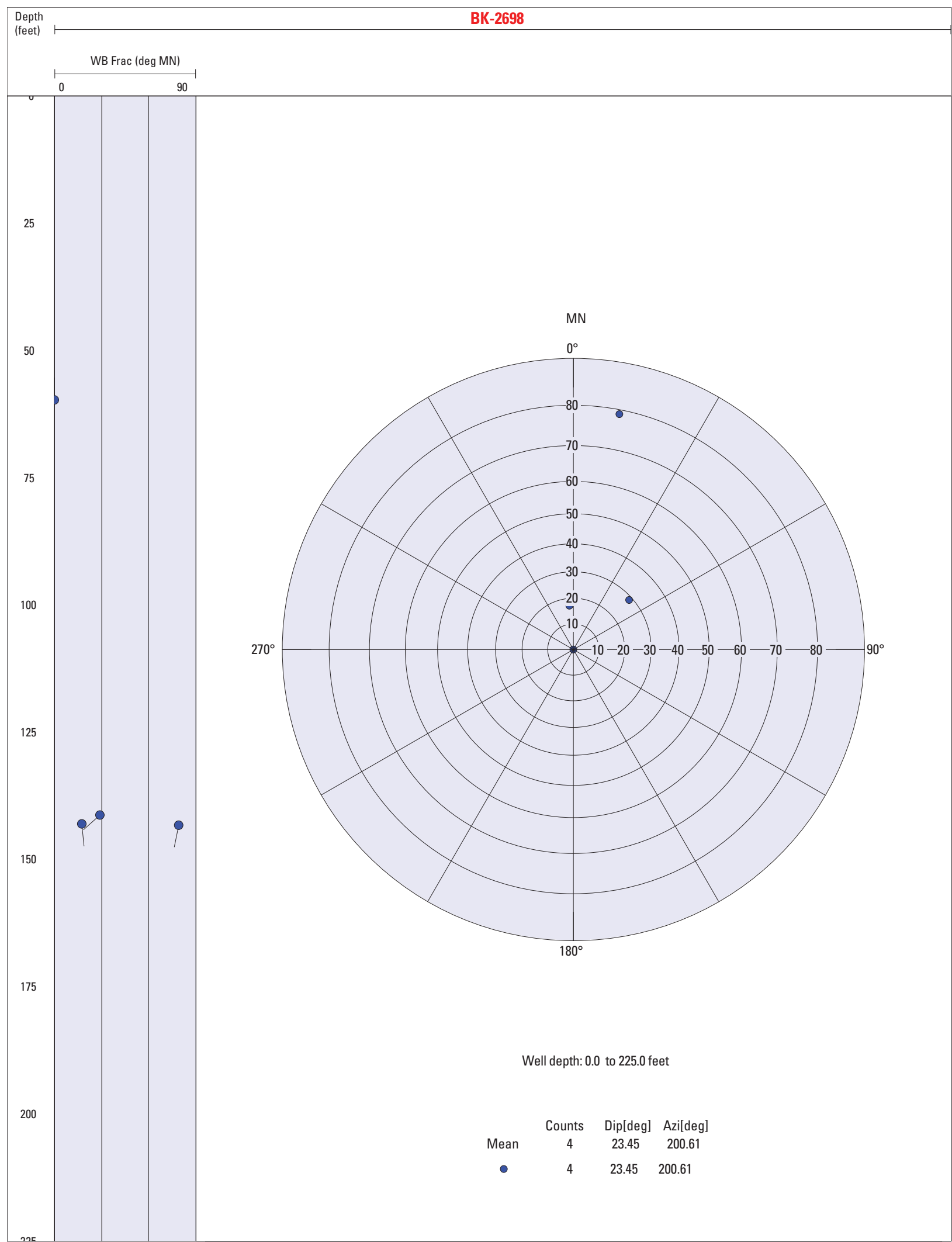

Figure 1.5. Orientation of selected water-bearing (WB) fractures relative to magnetic north (MN) as determined from evaluation of acoustic televiewer and other logs for well BK-2698, shown in (left) tadpole plot of fracture azimuth and dip in degrees by depth, and (right) lower hemisphere stereonet depicting projected pole to fracture plane and dip angle with distance from center of plot. Azi, azimuth; deg, degree; frac, fracture; ft, feet. 


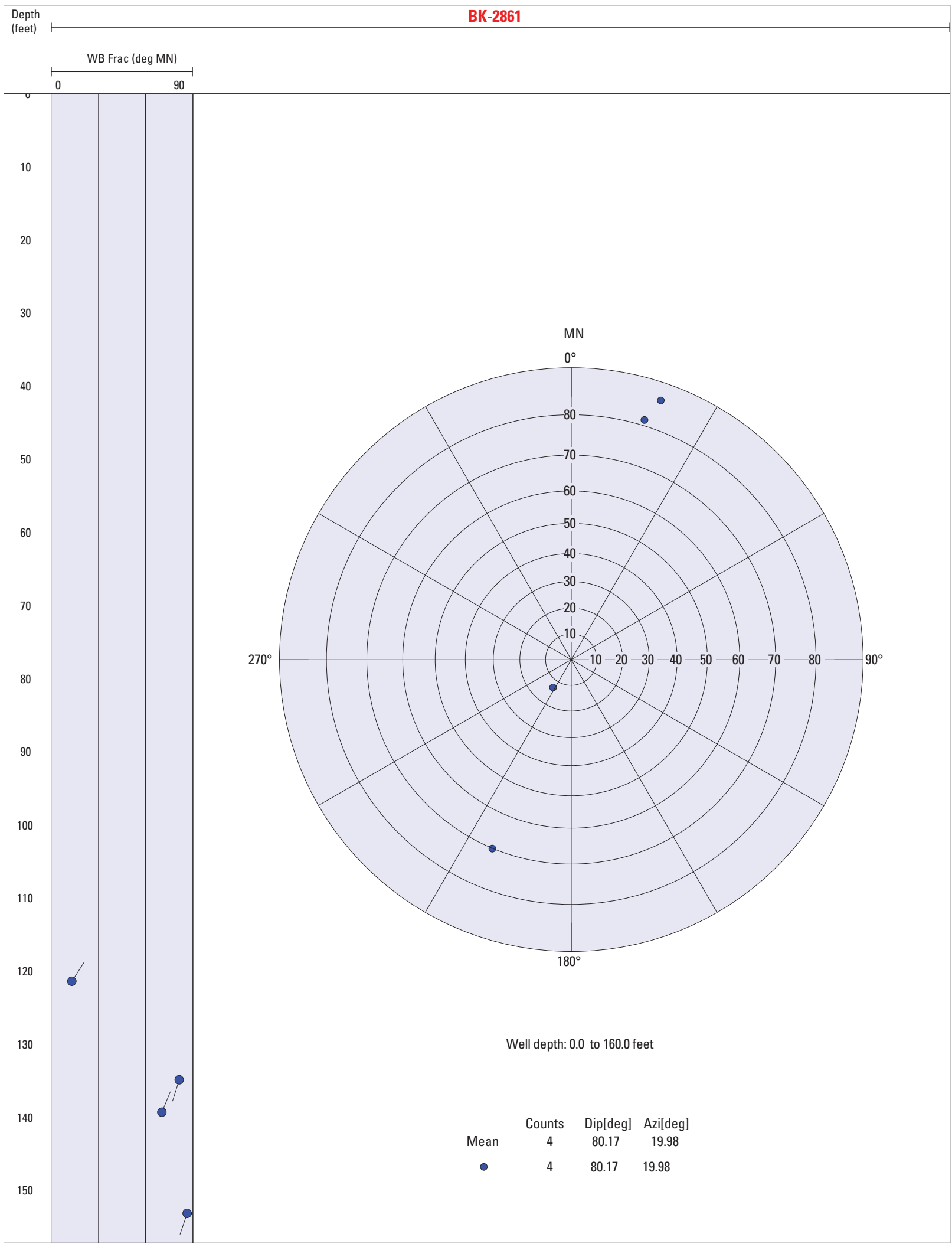

Figure 1.6. Orientation of selected water-bearing (WB) fractures relative to magnetic north (MN) as determined from evaluation of acoustic televiewer and other logs for well BK-2861, shown in (left) tadpole plot of fracture azimuth and dip in degrees by depth, and (right) lower hemisphere stereonet depicting projected pole to fracture plane and dip angle with distance from center of plot. Azi, azimuth; deg, degree; frac, fracture; $\mathrm{ft}$, feet. 


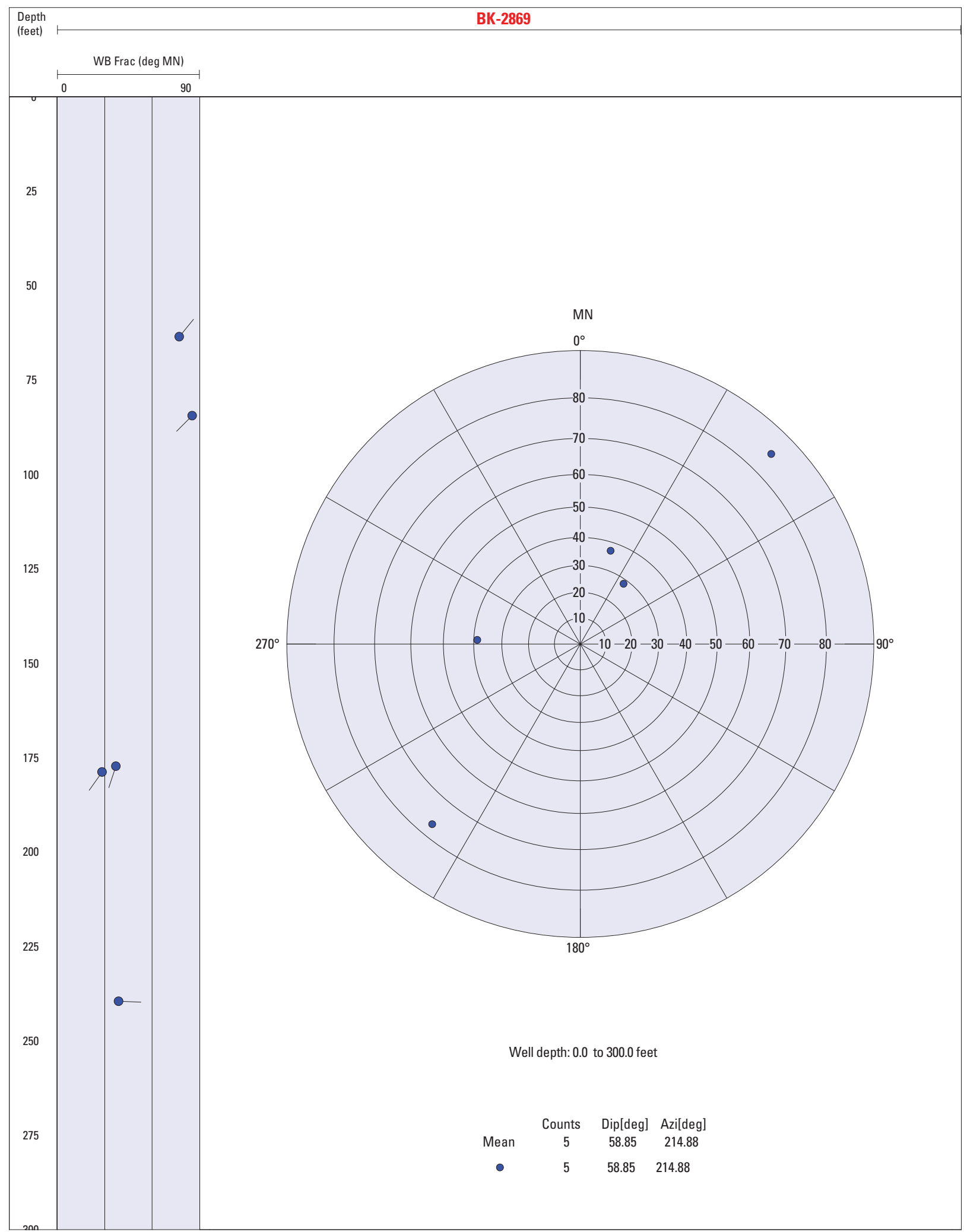

Figure 1.7. Orientation of selected water-bearing (WB) fractures relative to magnetic north (MN) as determined from evaluation of acoustic televiewer and other logs for well BK-2869, shown in (left) tadpole plot of fracture azimuth and dip in degrees by depth, and (right) lower hemisphere stereonet depicting projected pole to fracture plane and dip angle with distance from center of plot. Azi, azimuth; deg, degree; frac, fracture; ft, feet. 


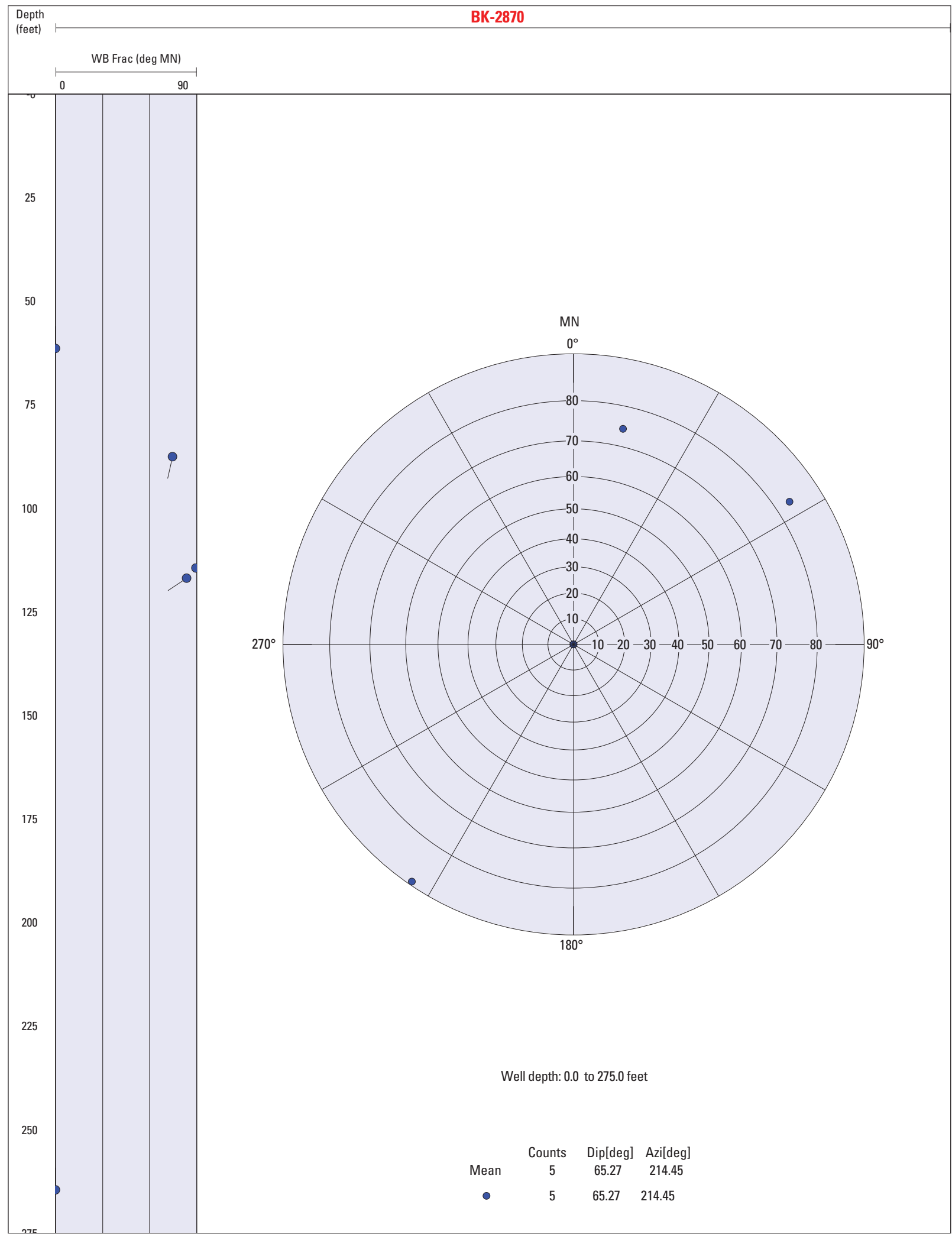

Figure 1.8. Orientation of selected water-bearing (WB) fractures relative to magnetic north (MN) as determined from evaluation of acoustic televiewer and other logs for well BK-2870, shown in (left) tadpole plot of fracture azimuth and dip in degrees by depth, and (right) lower hemisphere stereonet depicting projected pole to fracture plane and dip angle with distance from center of plot. Azi, azimuth; deg, degree; frac, fracture; ft, feet. 


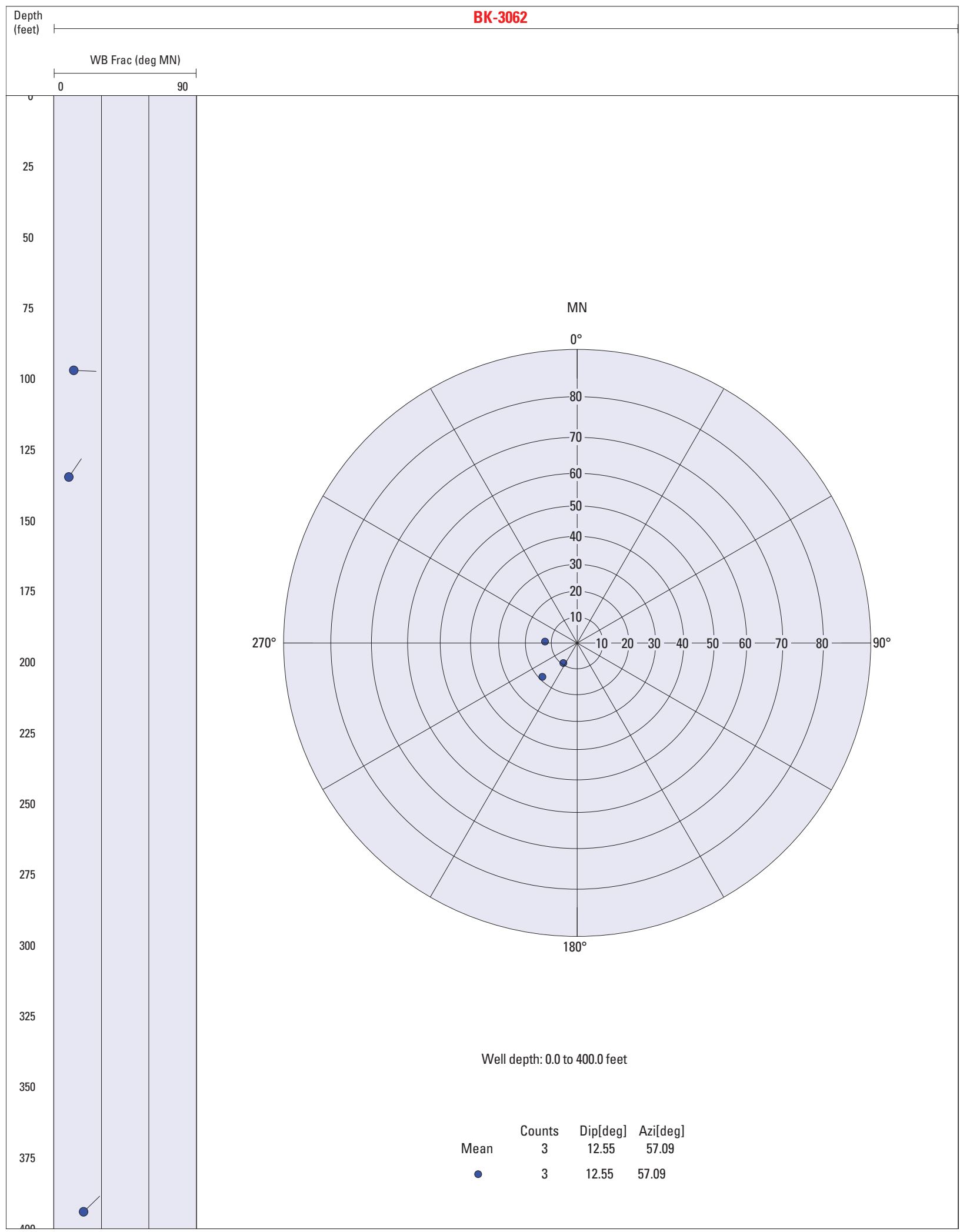

Figure 1.9. Orientation of selected water-bearing (WB) fractures relative to magnetic north (MN) as determined from evaluation of acoustic televiewer and other logs for well BK-3062, shown in (left) tadpole plot of fracture azimuth and dip in degrees by depth, and (right) lower hemisphere stereonet depicting projected pole to fracture plane and dip angle with distance from center of plot. Azi, azimuth; deg, degree; frac, fracture; ft, feet. 


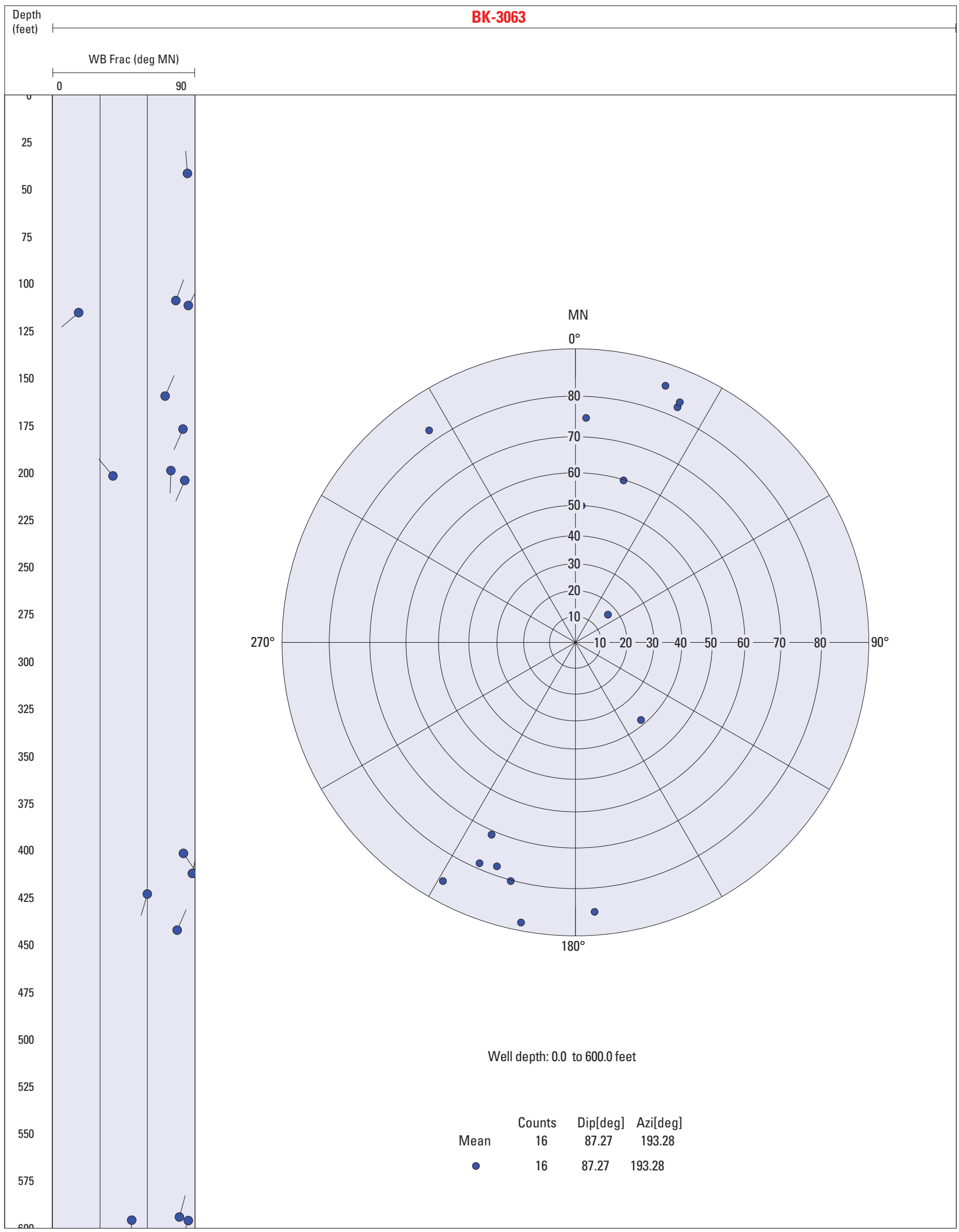

Figure 1.10. Orientation of selected water-bearing (WB) fractures relative to magnetic north (MN) as determined from evaluation of acoustic televiewer and other logs for well BK-3063, shown in (left) tadpole plot of fracture azimuth and dip in degrees by depth, and (right) lower hemisphere stereonet depicting projected pole to fracture plane and dip angle with distance from center of plot. Azi, azimuth; deg, degree; frac, fracture; ft, feet. 


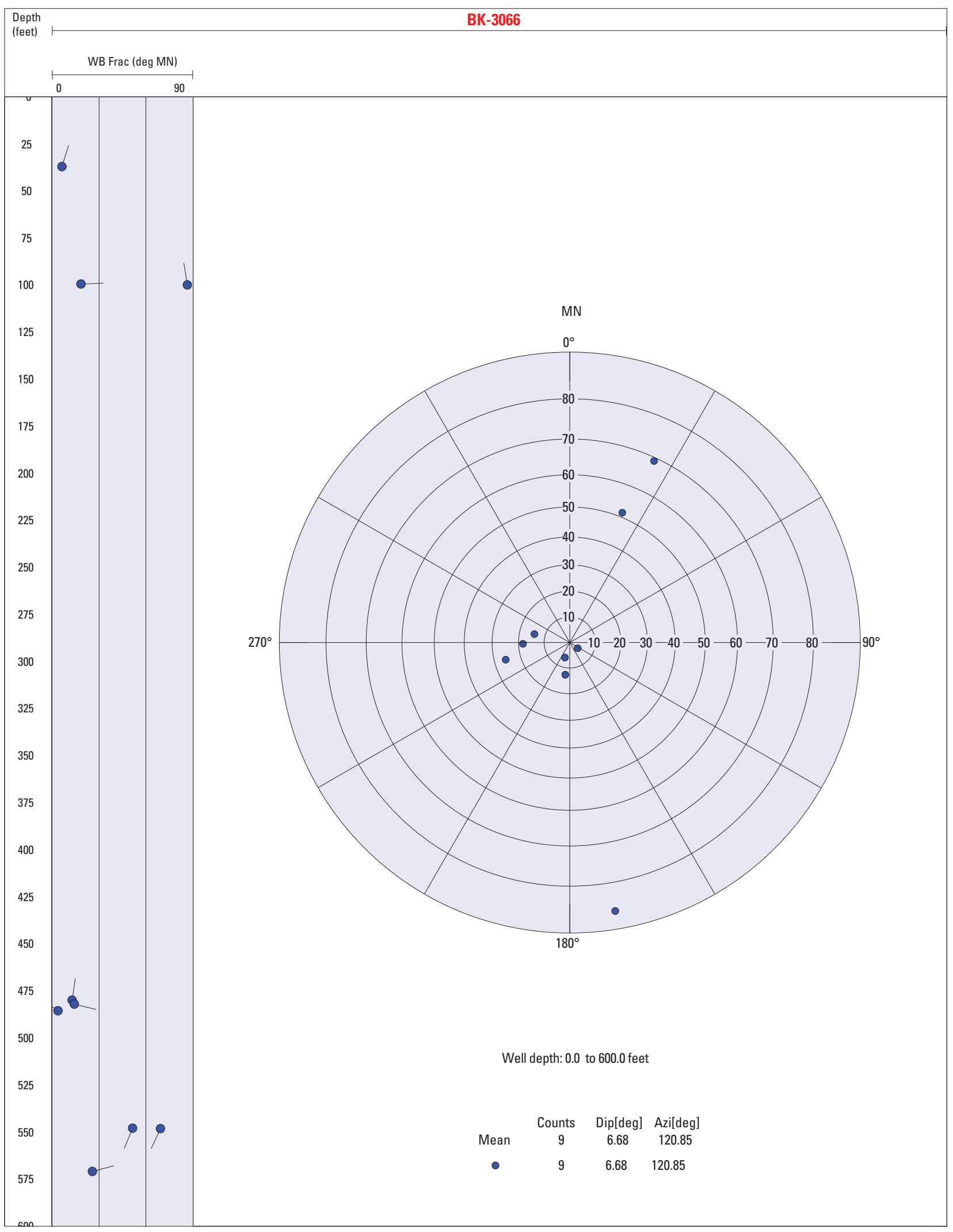

Figure 1.11. Orientation of selected water-bearing (WB) fractures relative to magnetic north (MN) as determined from evaluation of acoustic televiewer and other logs for well BK-3066, shown in (left) tadpole plot of fracture azimuth and dip in degrees by depth, and (right) lower hemisphere stereonet depicting projected pole to fracture plane and dip angle with distance from center of plot. Azi, azimuth; deg, degree; frac, fracture; ft, feet. 


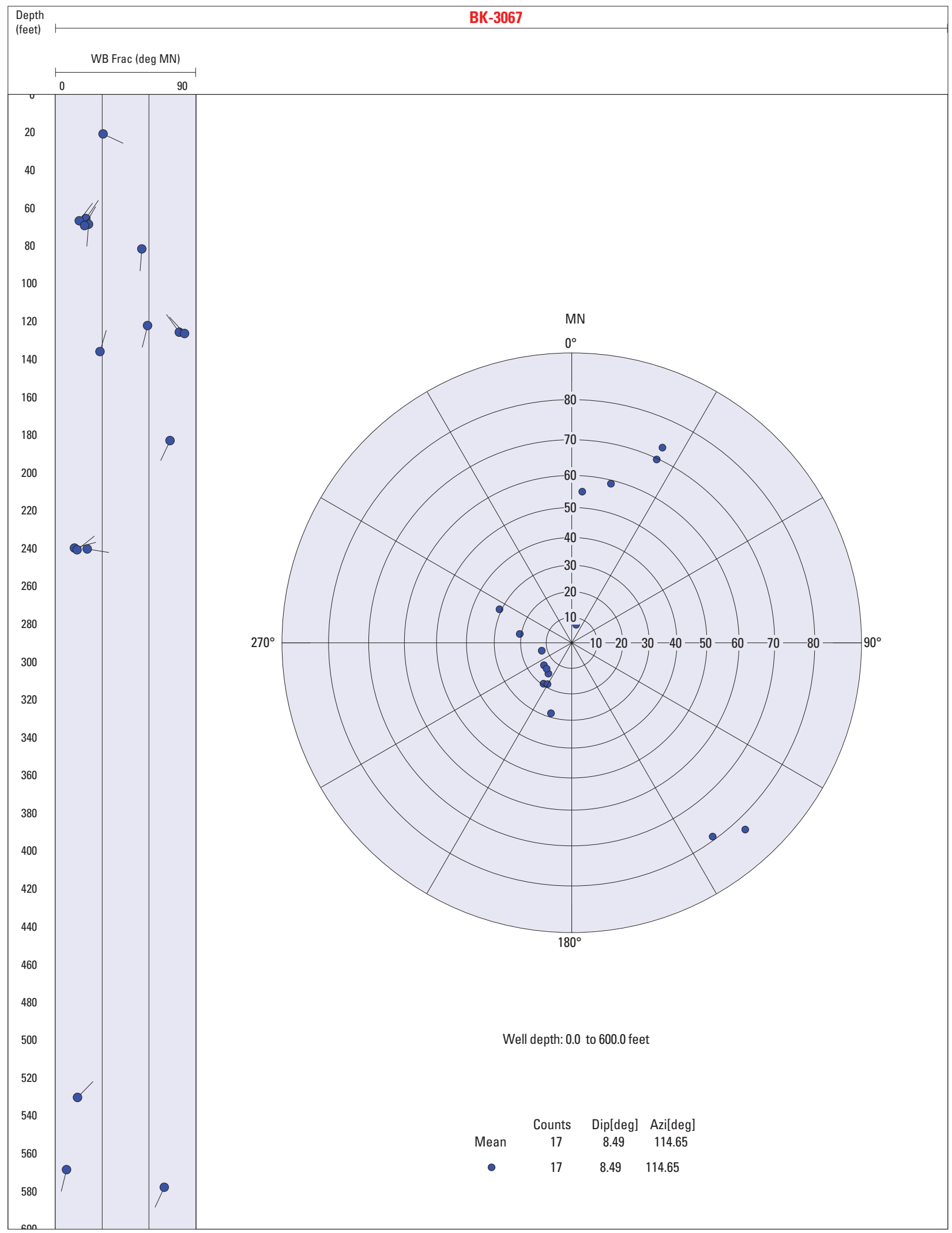

Figure 1.12. Orientation of selected water-bearing (WB) fractures relative to magnetic north (MN) as determined from evaluation of acoustic televiewer and other logs for well BK-3067, shown in (left) tadpole plot of fracture azimuth and dip in degrees by depth, and (right) lower hemisphere stereonet depicting projected pole to fracture plane and dip angle with distance from center of plot. Azi, azimuth; deg, degree; frac, fracture; ft, feet. 


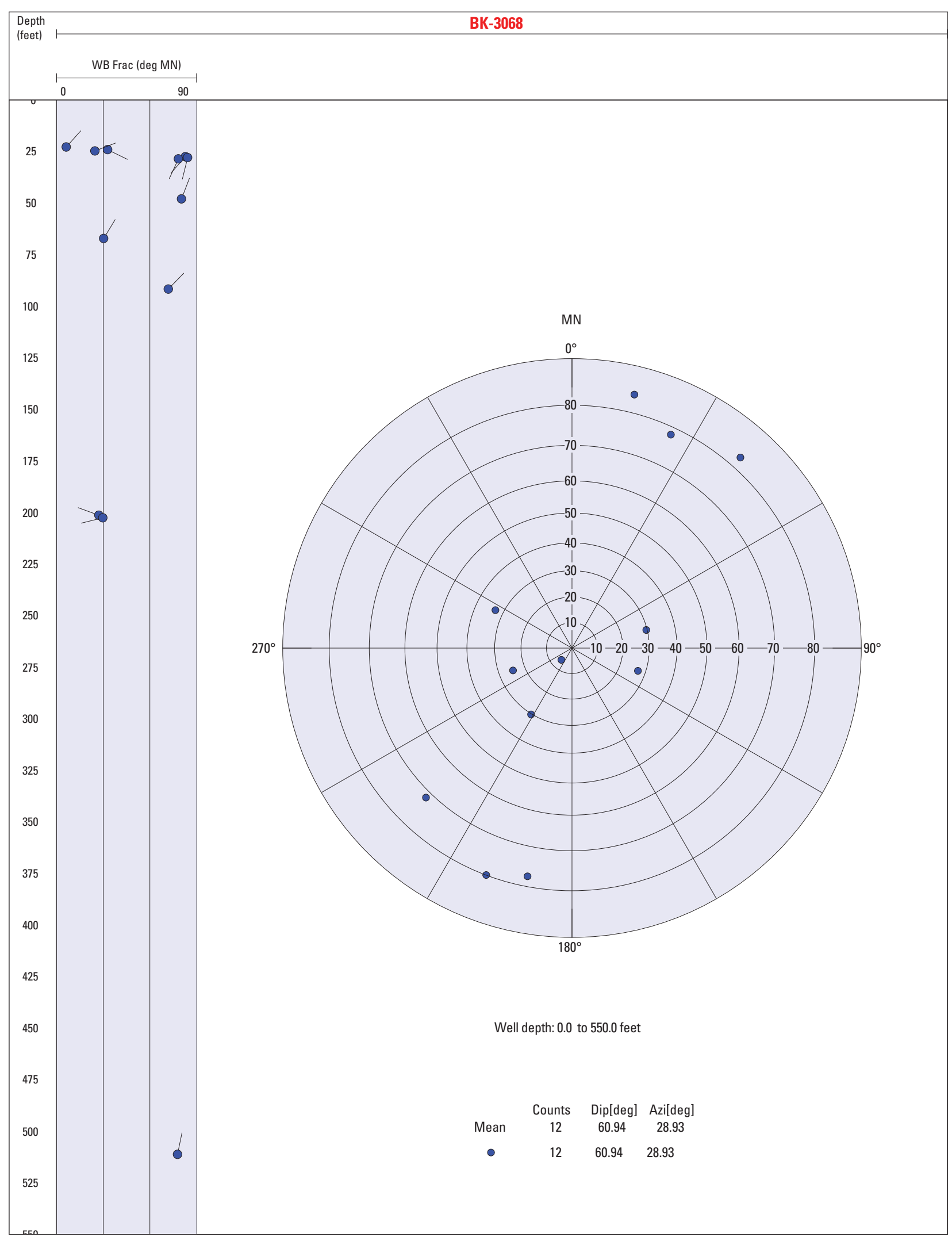

Figure 1.13. Orientation of selected water-bearing (WB) fractures relative to magnetic north (MN) as determined from evaluation of acoustic televiewer and other logs for well BK-3068, shown in (left) tadpole plot of fracture azimuth and dip in degrees by depth, and (right) lower hemisphere stereonet depicting projected pole to fracture plane and dip angle with distance from center of plot. Azi, azimuth; deg, degree; frac, fracture; ft, feet. 


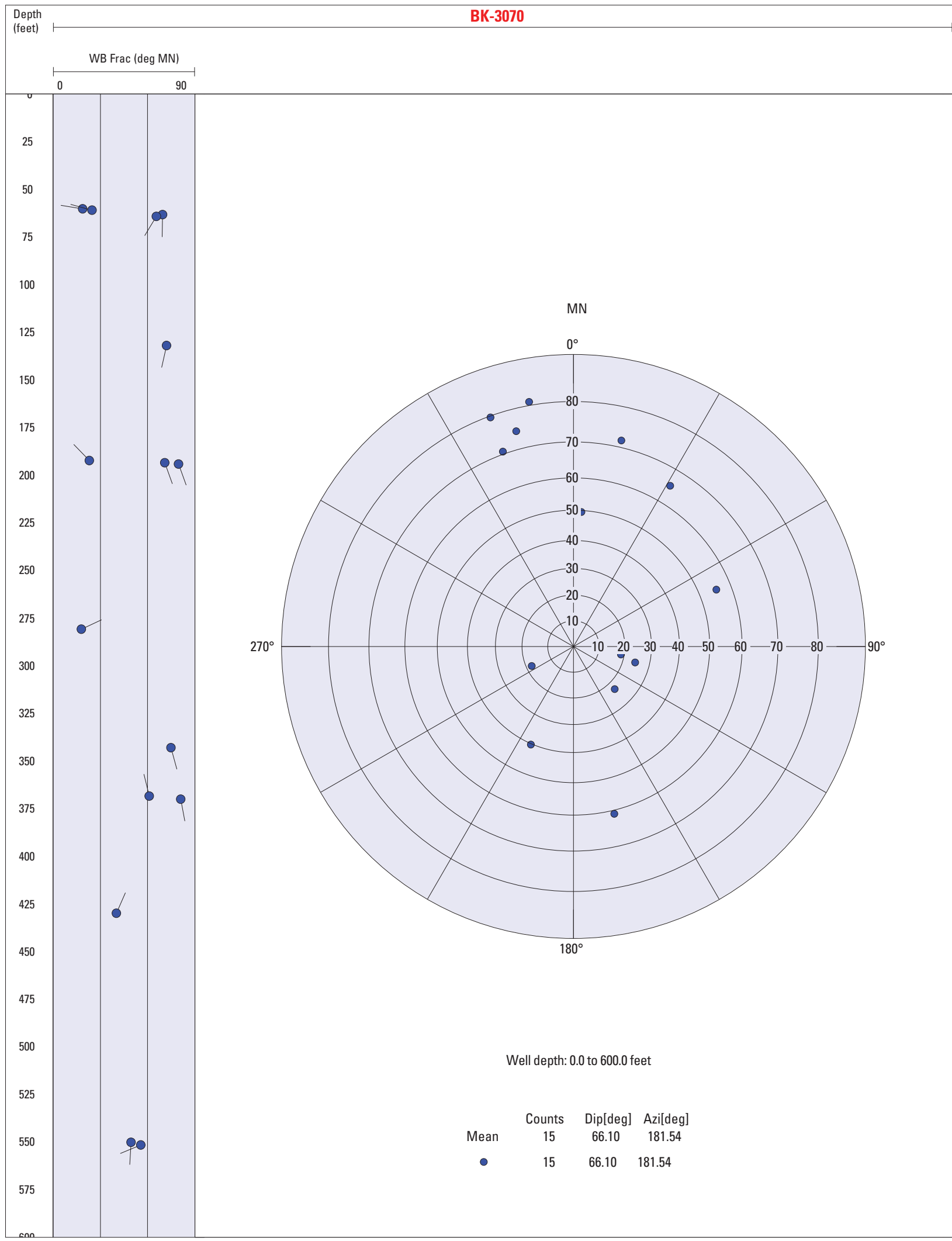

Figure 1.14. Orientation of selected water-bearing (WB) fractures relative to magnetic north (MN) as determined from evaluation of acoustic televiewer and other logs for well BK-3070, shown in (left) tadpole plot of fracture azimuth and dip in degrees by depth, and (right) lower hemisphere stereonet depicting projected pole to fracture plane and dip angle with distance from center of plot. Azi, azimuth; deg, degree; frac, fracture; ft, feet. 


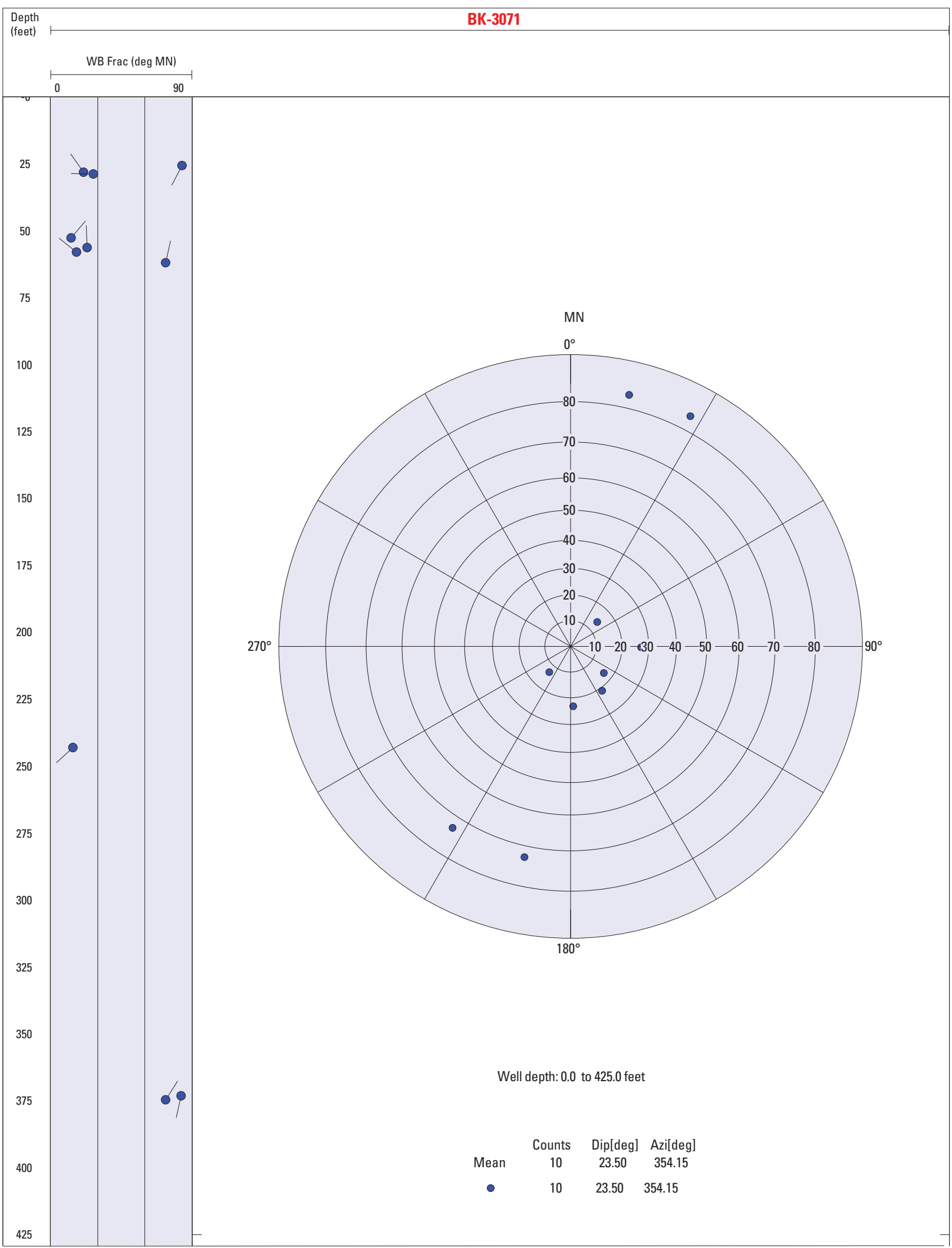

Figure 1.15. Orientation of selected water-bearing (WB) fractures relative to magnetic north (MN) as determined from evaluation of acoustic televiewer and other logs for well BK-3071, shown in (left) tadpole plot of fracture azimuth and dip in degrees by depth, and (right) lower hemisphere stereonet depicting projected pole to fracture plane and dip angle with distance from center of plot. Azi, azimuth; deg, degree; frac, fracture; ft, feet. 


\section{Appendix 2. Deviation and Drift of Boreholes}




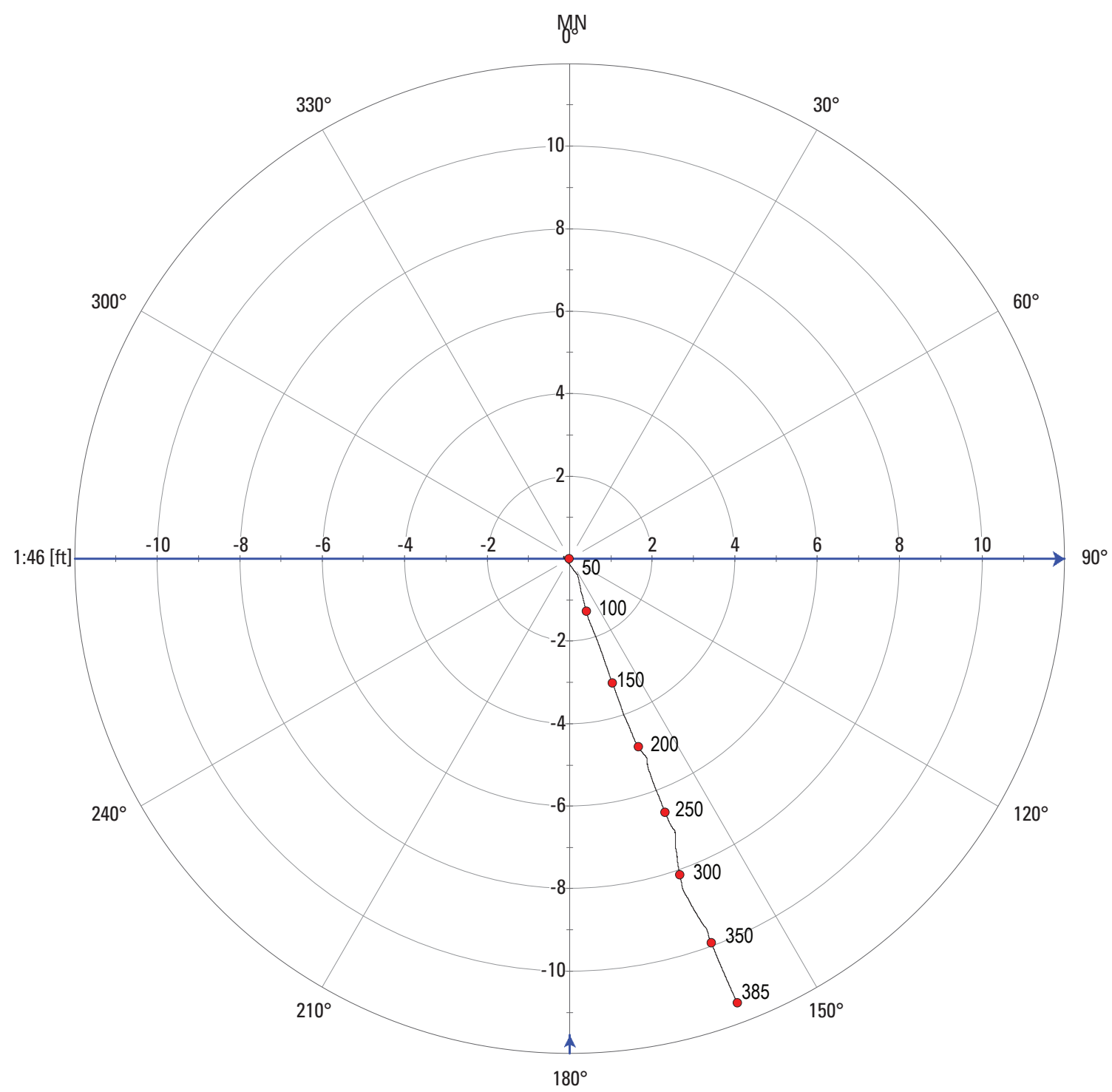

Well-bore depth, in feet (ft) along path

$\bullet-50.0 \mathrm{ft} \bullet$ Path

Figure 2.1. Interpretation of well-bore drift (path) as determined from orientation data collected with acoustic televiewer logs for well BK-962. Direction of path in degrees relative to magnetic north (MN) and deviation from vertical in feet (ft) shown at selected depths. Top of borehole at center of plot. Path of borehole shown at 50-foot depth intervals. 


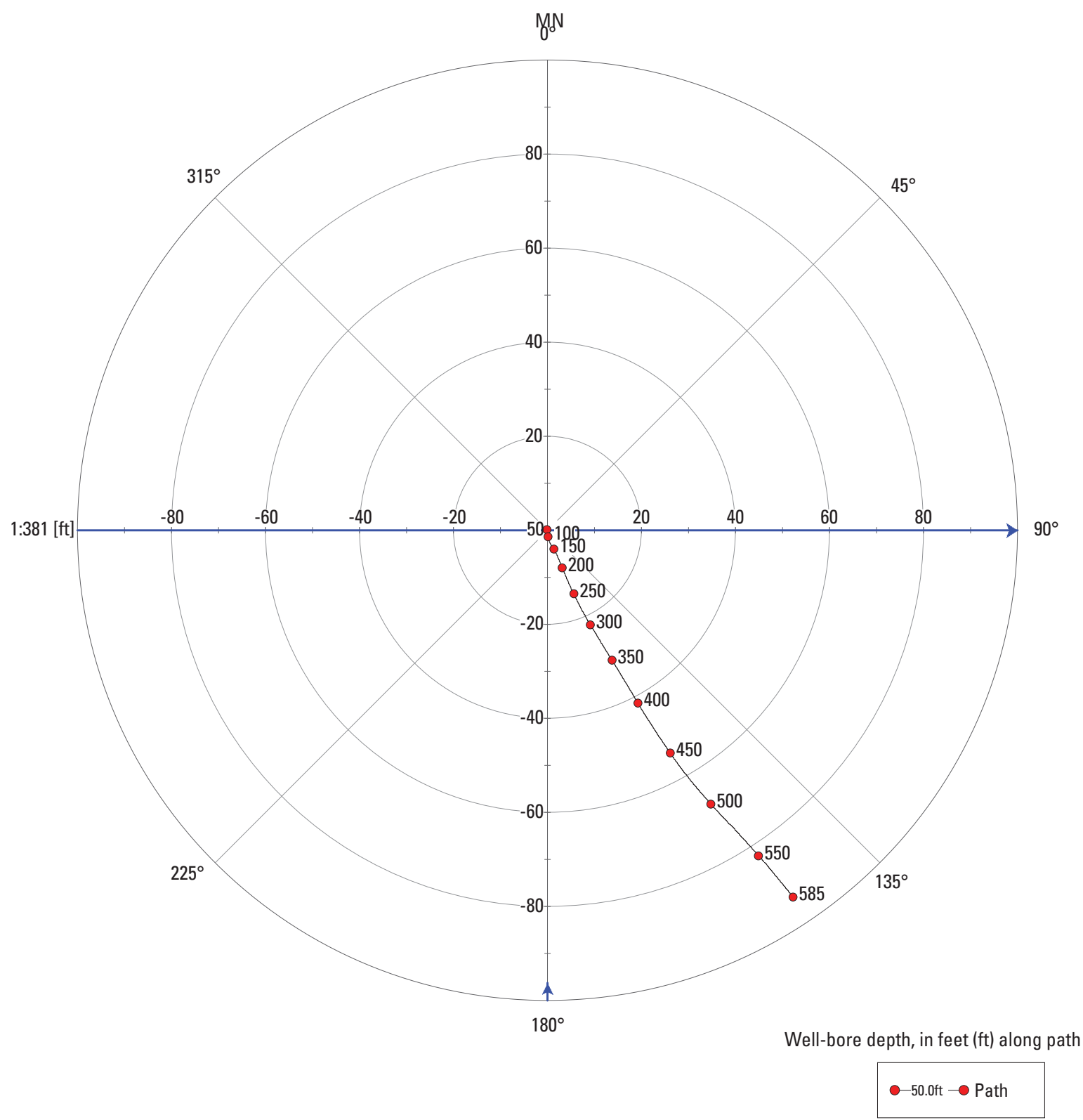

Figure 2.2. Interpretation of well-bore drift (path) as determined from orientation data collected with acoustic televiewer logs for well BK-1023. Direction of path in degrees relative to magnetic north (MN) and deviation from vertical in feet (ft) shown at selected depths. Top of borehole at center of plot. Path of borehole shown at 50-foot depth intervals. 


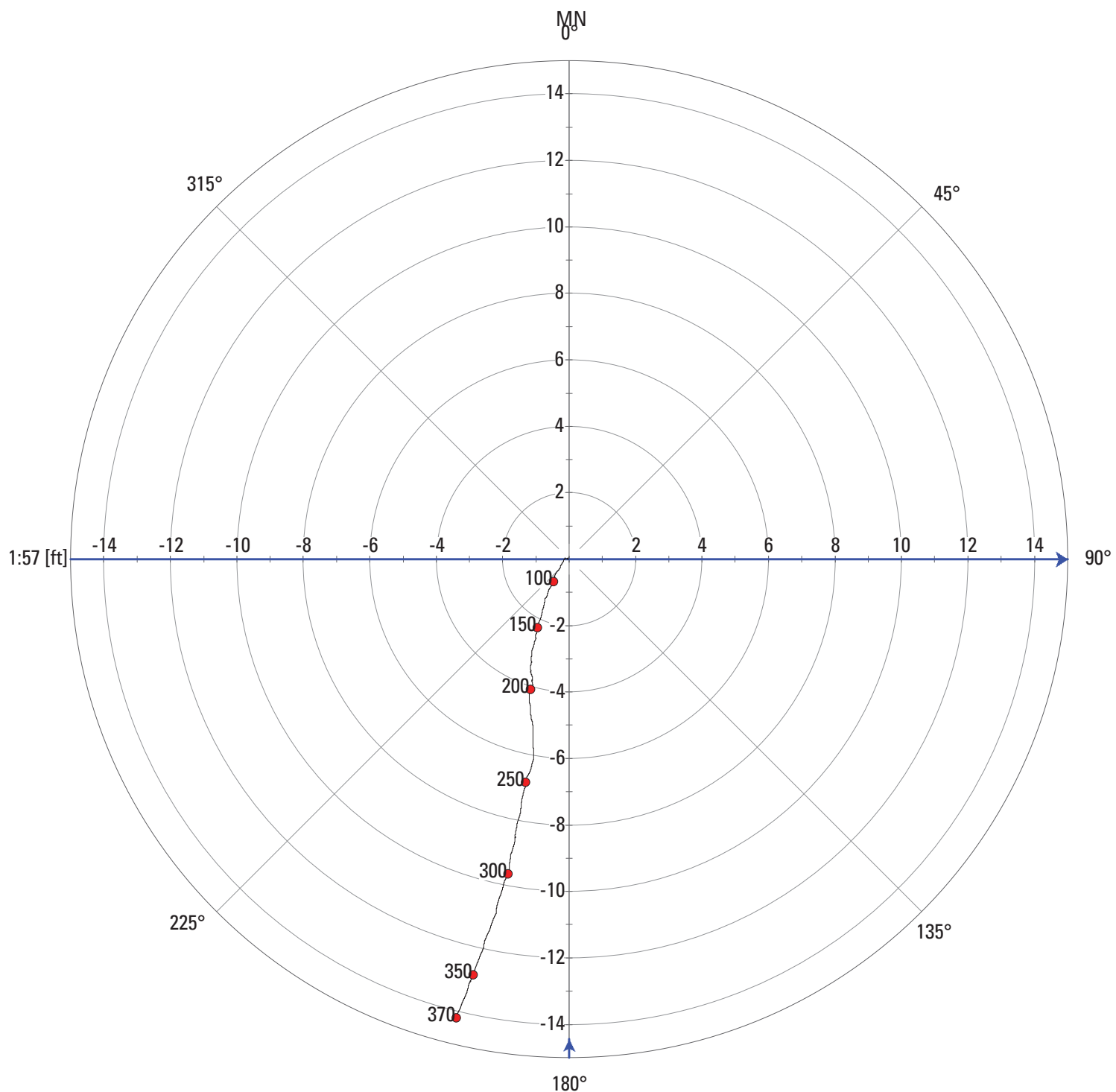

Well-bore depth, in feet (ft) along path

$-50.0 f t \rightarrow$ Path

Figure 2.3. Interpretation of well-bore drift (path) as determined from orientation data collected with acoustic televiewer logs for well BK-1087. Direction of path in degrees relative to magnetic north (MN) and deviation from vertical in feet (ft) shown at selected depths. Top of borehole at center of plot. Path of borehole shown at 50-foot depth intervals. 


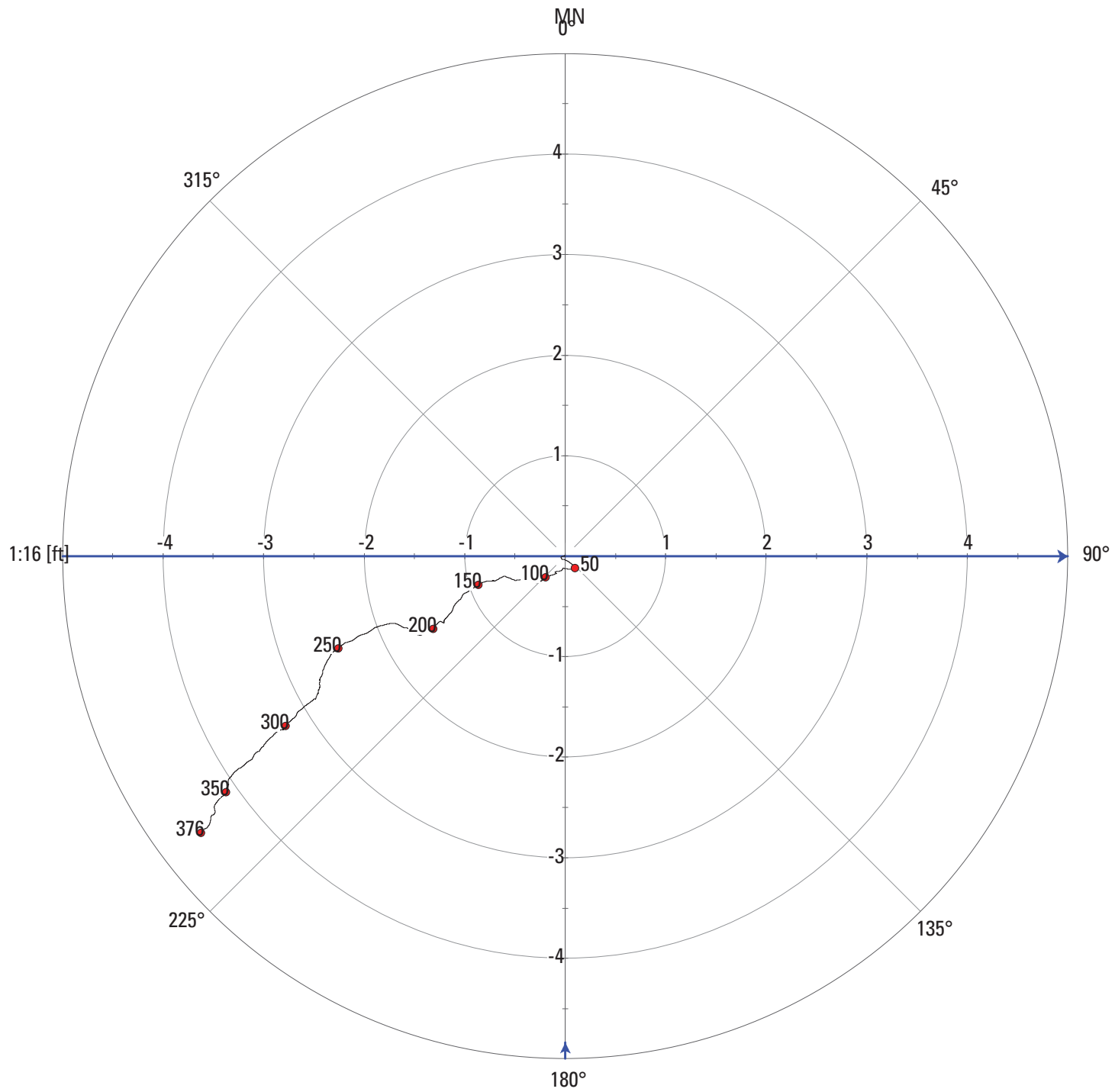

Well-bore depth, in feet (ft) along path

- $-50.0 \mathrm{ft} \longrightarrow$ Path

Figure 2.4. Interpretation of well-bore drift (path) as determined from orientation data collected with acoustic televiewer logs for well BK-1129. Direction of path in degrees relative to magnetic north (MN) and deviation from vertical in feet (ft) shown at selected depths. Top of borehole at center of plot. Path of borehole shown at 50-foot depth intervals. 


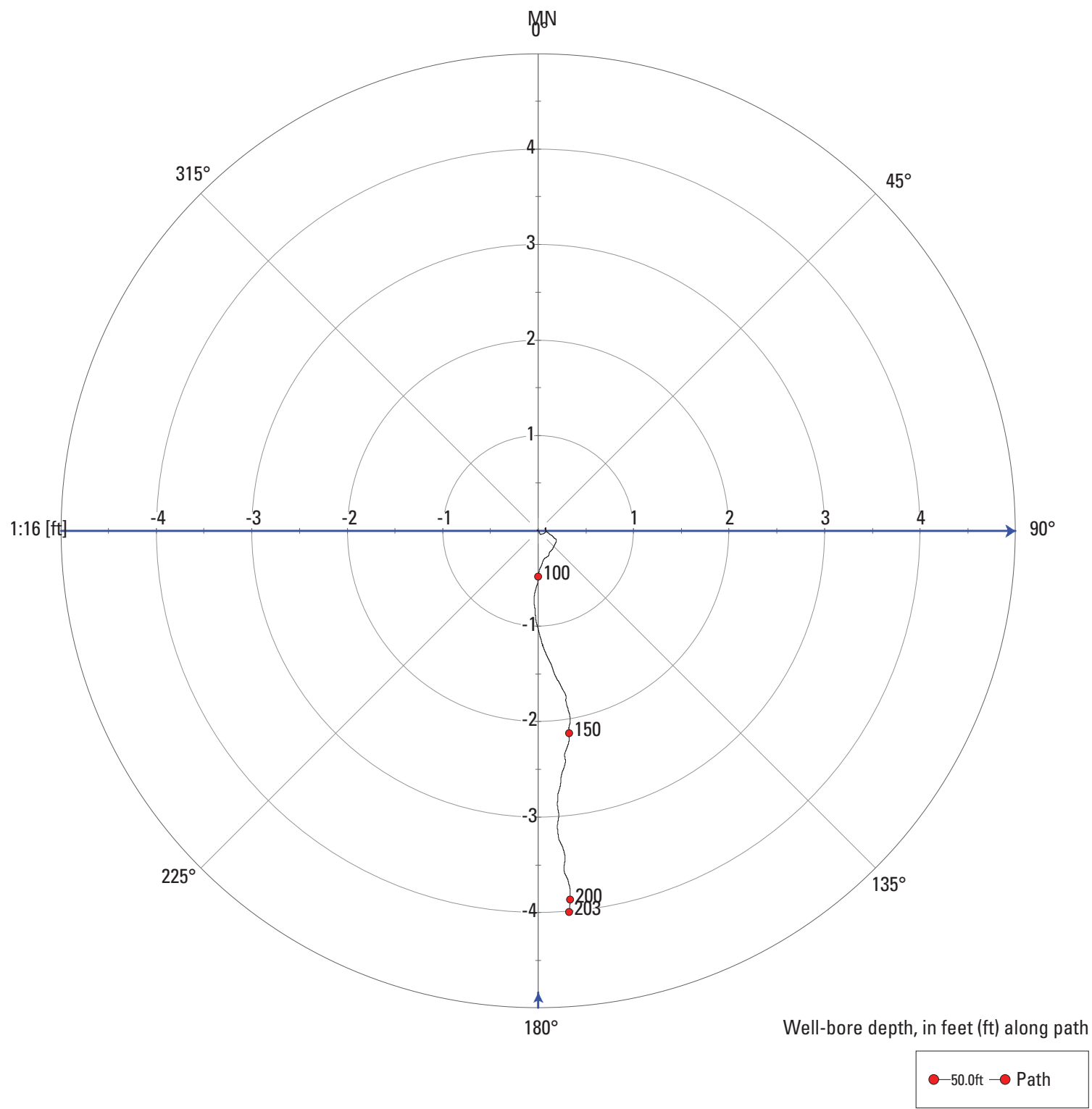

Figure 2.5. Interpretation of well-bore drift (path) as determined from orientation data collected with acoustic televiewer logs for well BK-2698. Direction of path in degrees relative to magnetic north (MN) and deviation from vertical in feet ( $\mathrm{ft}$ ) shown at selected depths. Top of borehole at center of plot. Path of borehole shown at 50-foot depth intervals. 


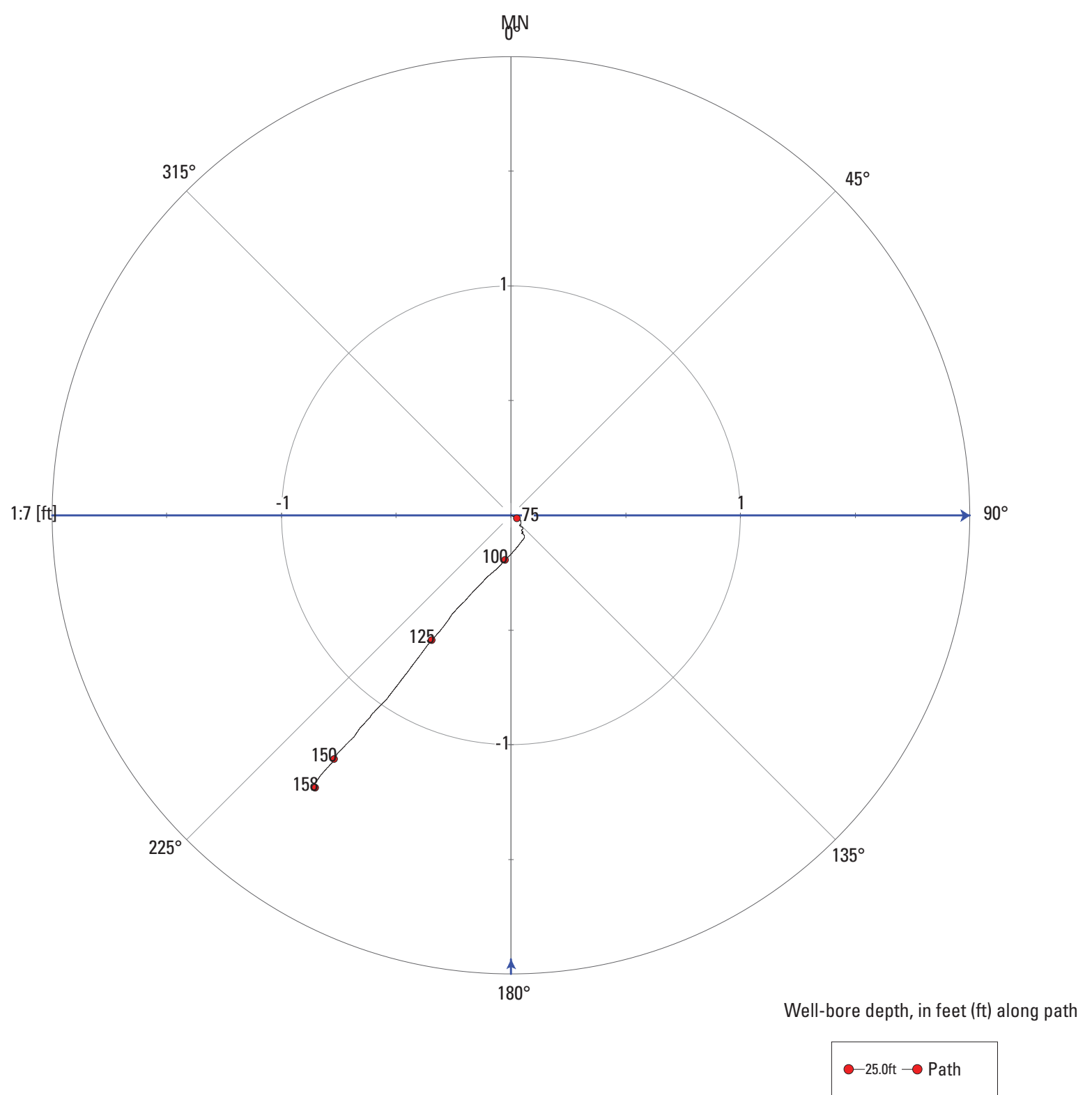

Figure 2.6. Interpretation of well-bore drift (path) as determined from orientation data collected with acoustic televiewer logs for well BK-2861. Direction of path in degrees relative to magnetic north (MN) and deviation from vertical in feet (ft) shown at selected depths. Top of borehole at center of plot. Path of borehole shown at 25 -foot depth intervals. 


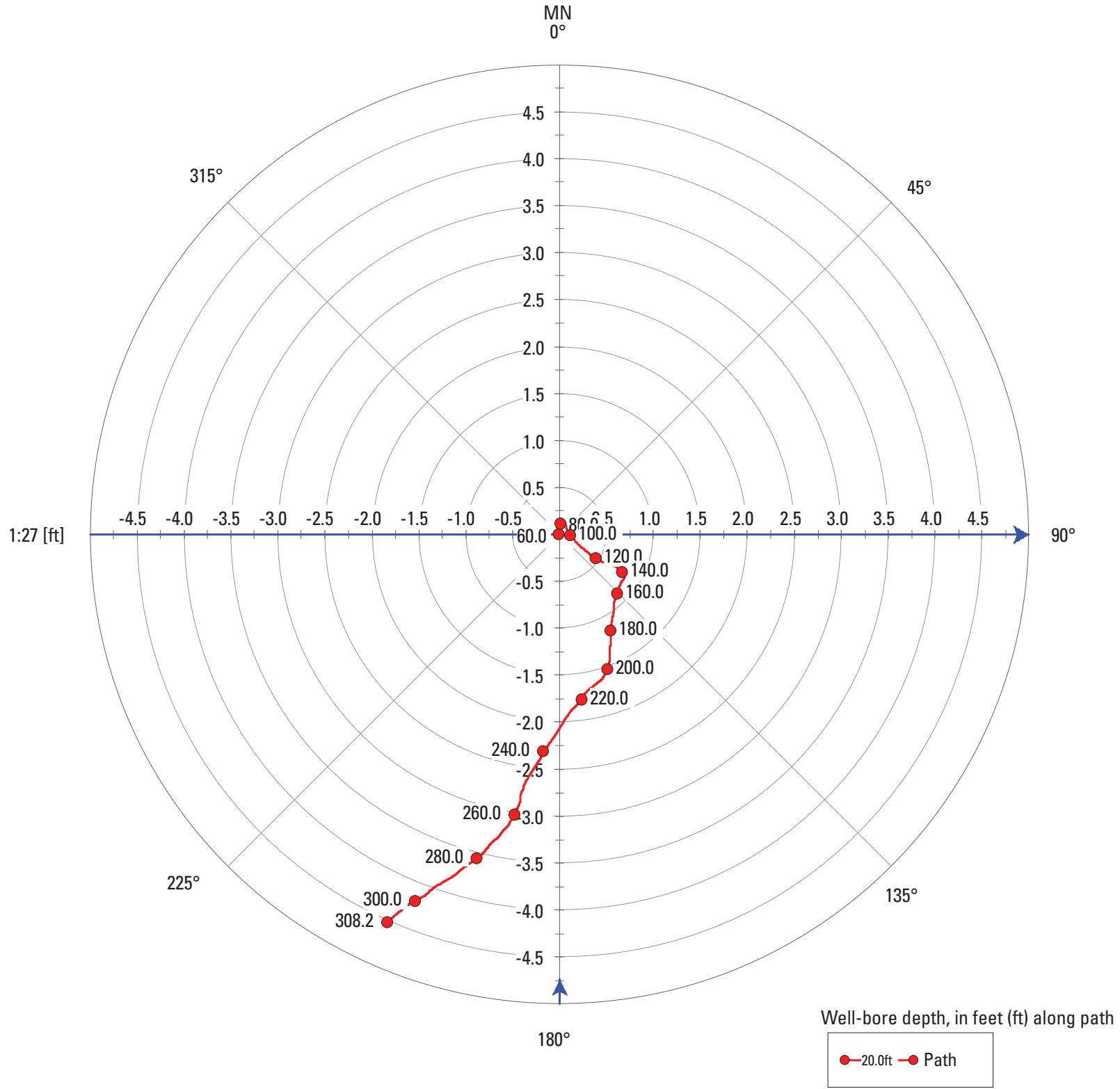

Figure 2.7. Interpretation of well-bore drift (path) as determined from orientation data collected with acoustic televiewer logs for well BK-2869. Direction of path in degrees relative to magnetic north (MN) and deviation from vertical in feet (ft) shown at selected depths. Top of borehole at center of plot. Path of borehole shown at 20-foot depth intervals. 


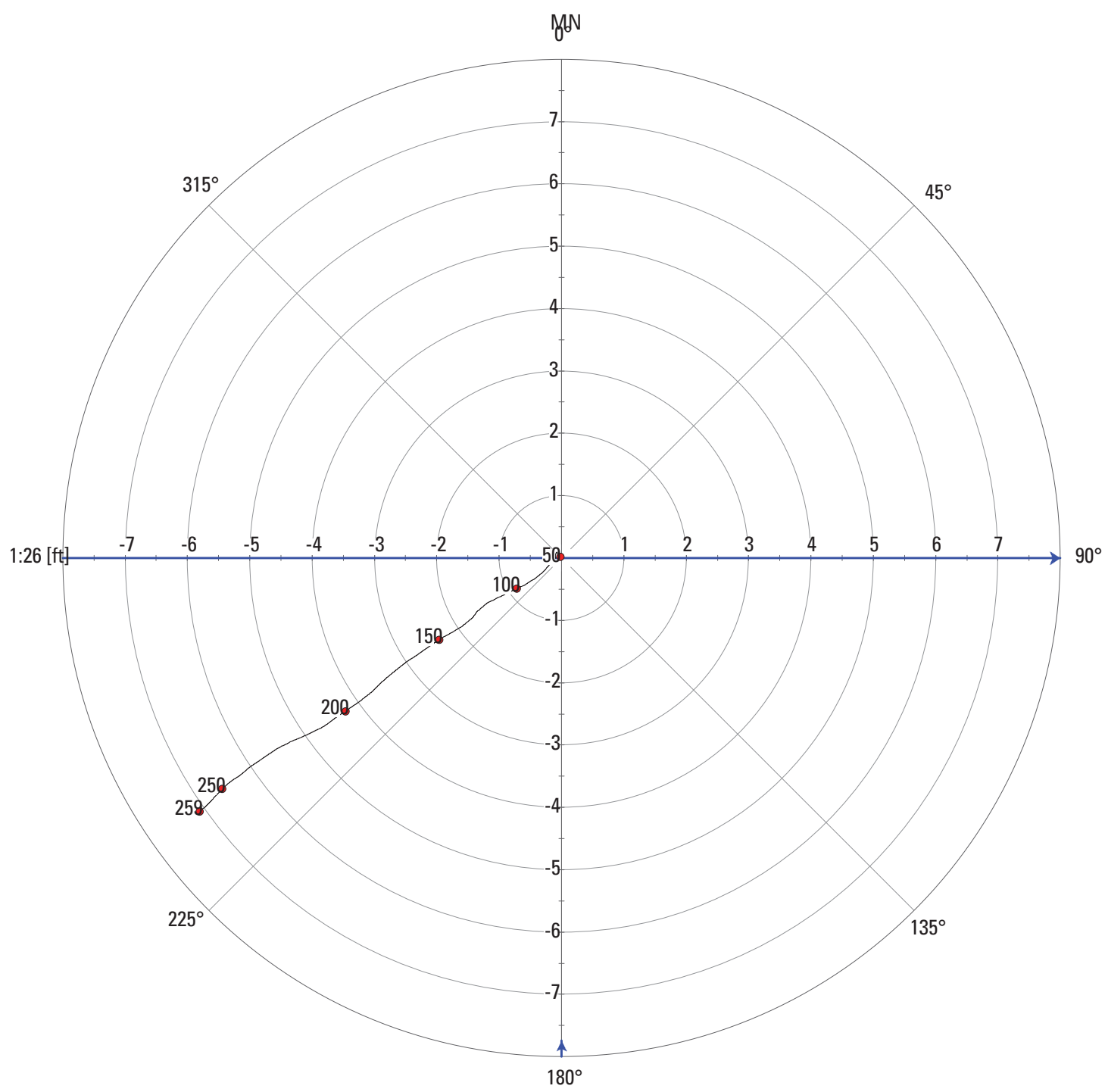

Well-bore depth, in feet (ft) along path

$\bullet-50.0 f t \rightarrow$ Path

Figure 2.8. Interpretation of well-bore drift (path) as determined from orientation data collected with acoustic televiewer logs for well BK-2870. Direction of path in degrees relative to magnetic north (MN) and deviation from vertical in feet (ft) shown at selected depths. Top of borehole at center of plot. Path of borehole shown at 50-foot depth intervals. 


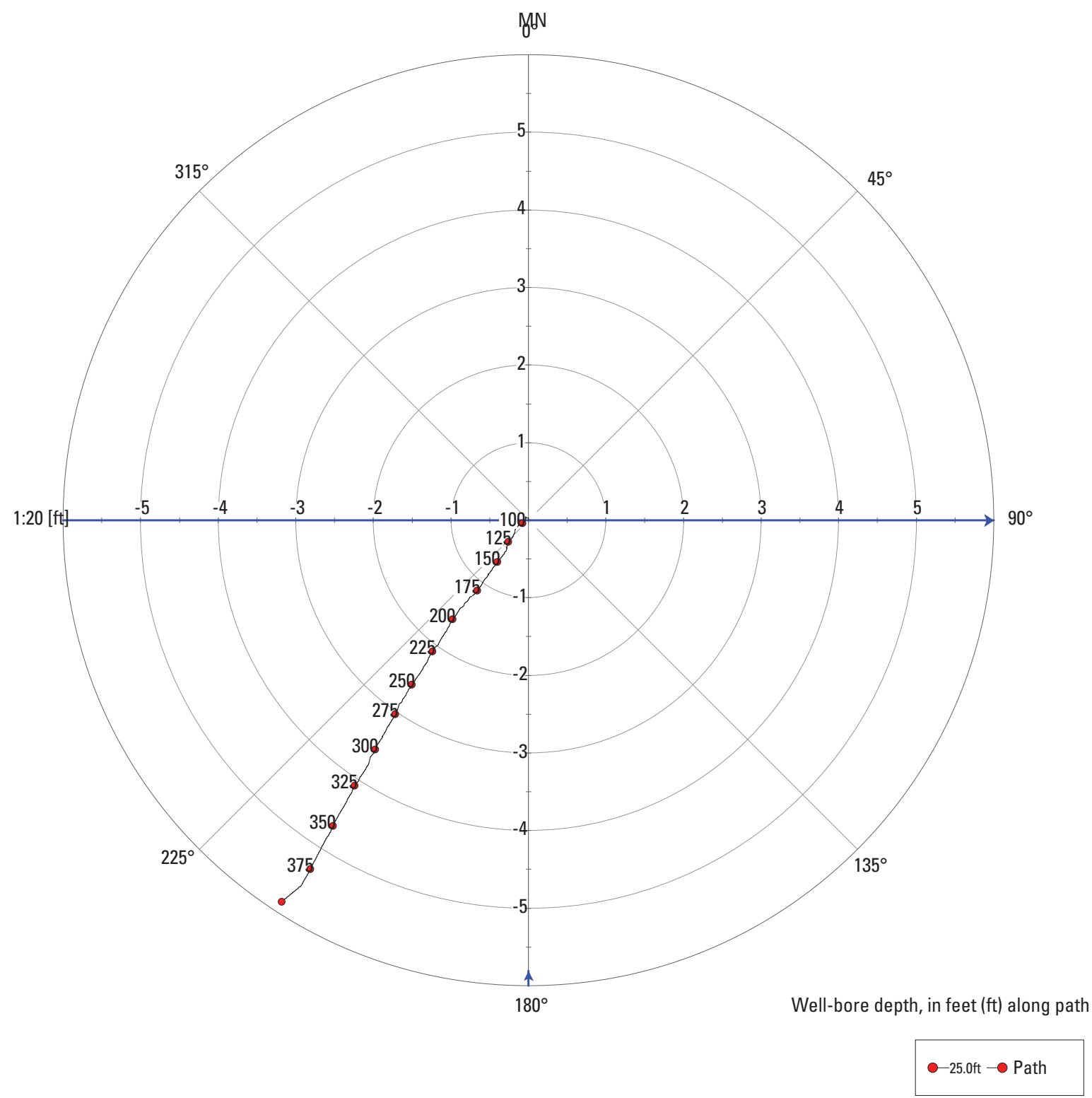

Figure 2.9. Interpretation of well-bore drift (path) as determined from orientation data collected with acoustic televiewer logs for well BK-3062. Direction of path in degrees relative to magnetic north (MN) and deviation from vertical in feet ( $\mathrm{ft}$ ) shown at selected depths. Top of borehole at center of plot. Path of borehole shown at 25-foot depth intervals. 


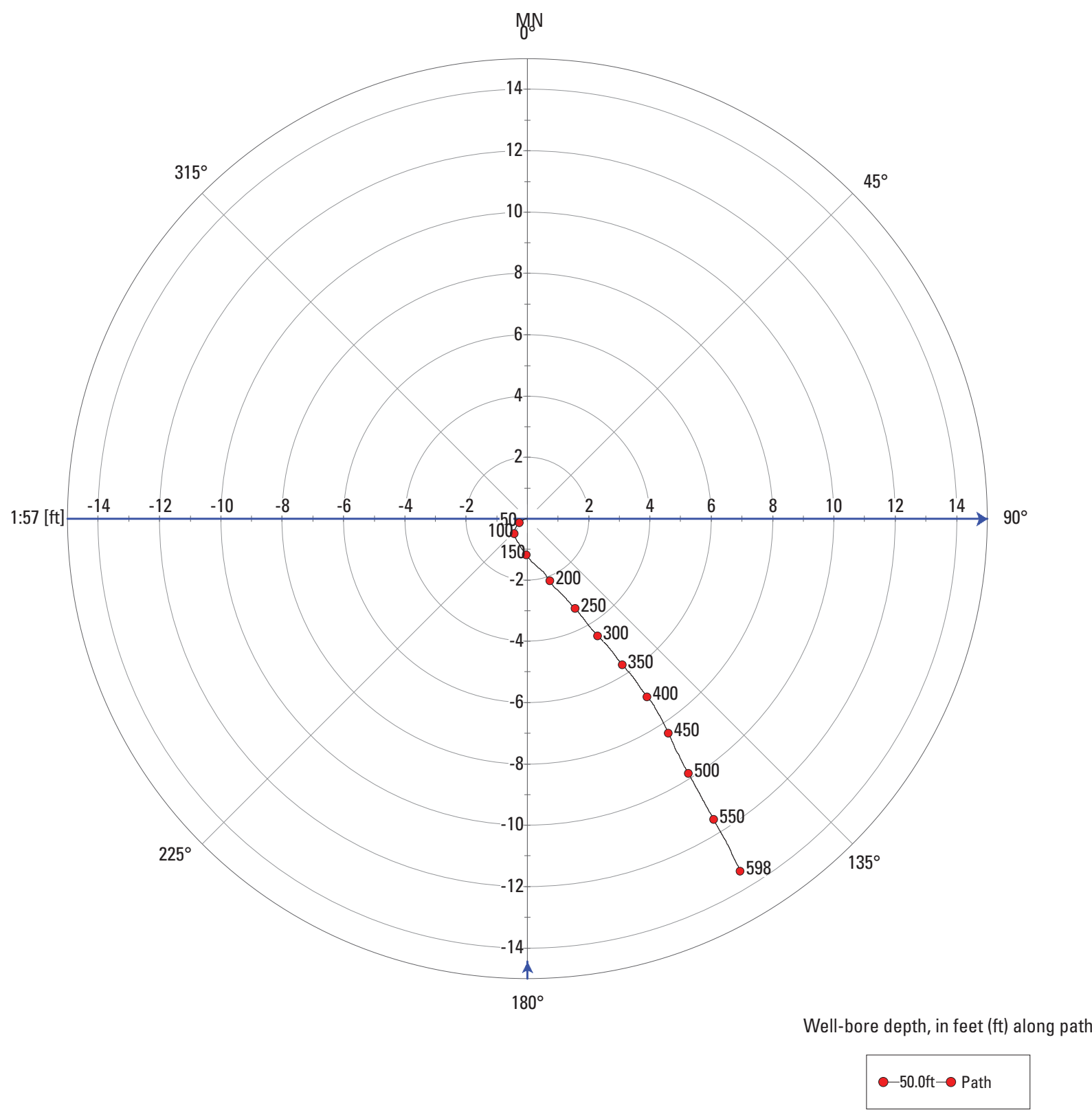

Figure 2.10. Interpretation of well-bore drift (path) as determined from orientation data collected with acoustic televiewer logs for well BK-3063. Direction of path in degrees relative to magnetic north (MN) and deviation from vertical in feet (ft) shown at selected depths. Top of borehole at center of plot. Path of borehole shown at 50 -foot depth intervals. 


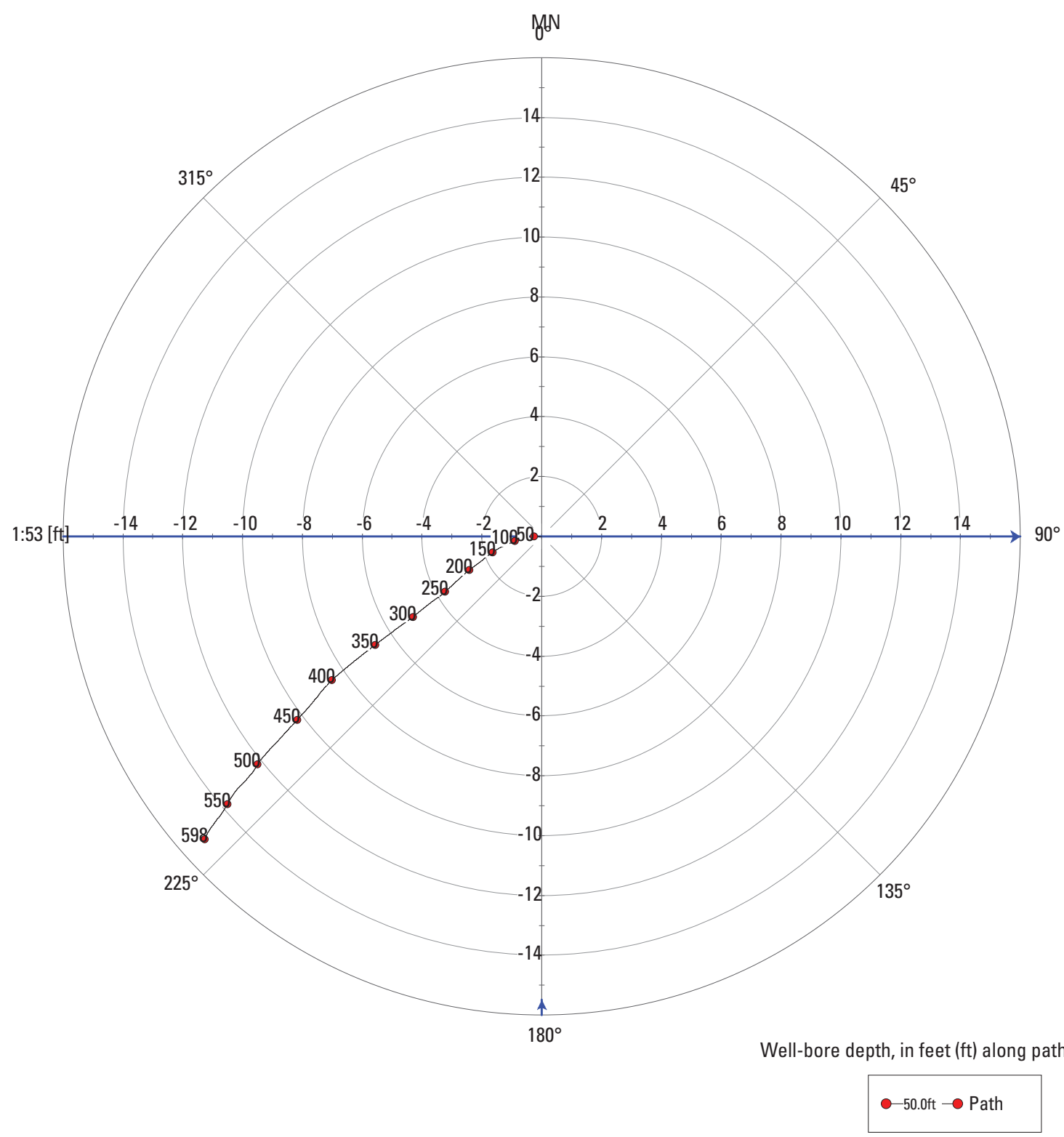

Figure 2.11. Interpretation of well-bore drift (path) as determined from orientation data collected with acoustic televiewer logs for well BK-3066. Direction of path in degrees relative to magnetic north (MN) and deviation from vertical in feet (ft) shown at selected depths. Top of borehole at center of plot. Path of borehole shown at 50-foot depth intervals. 


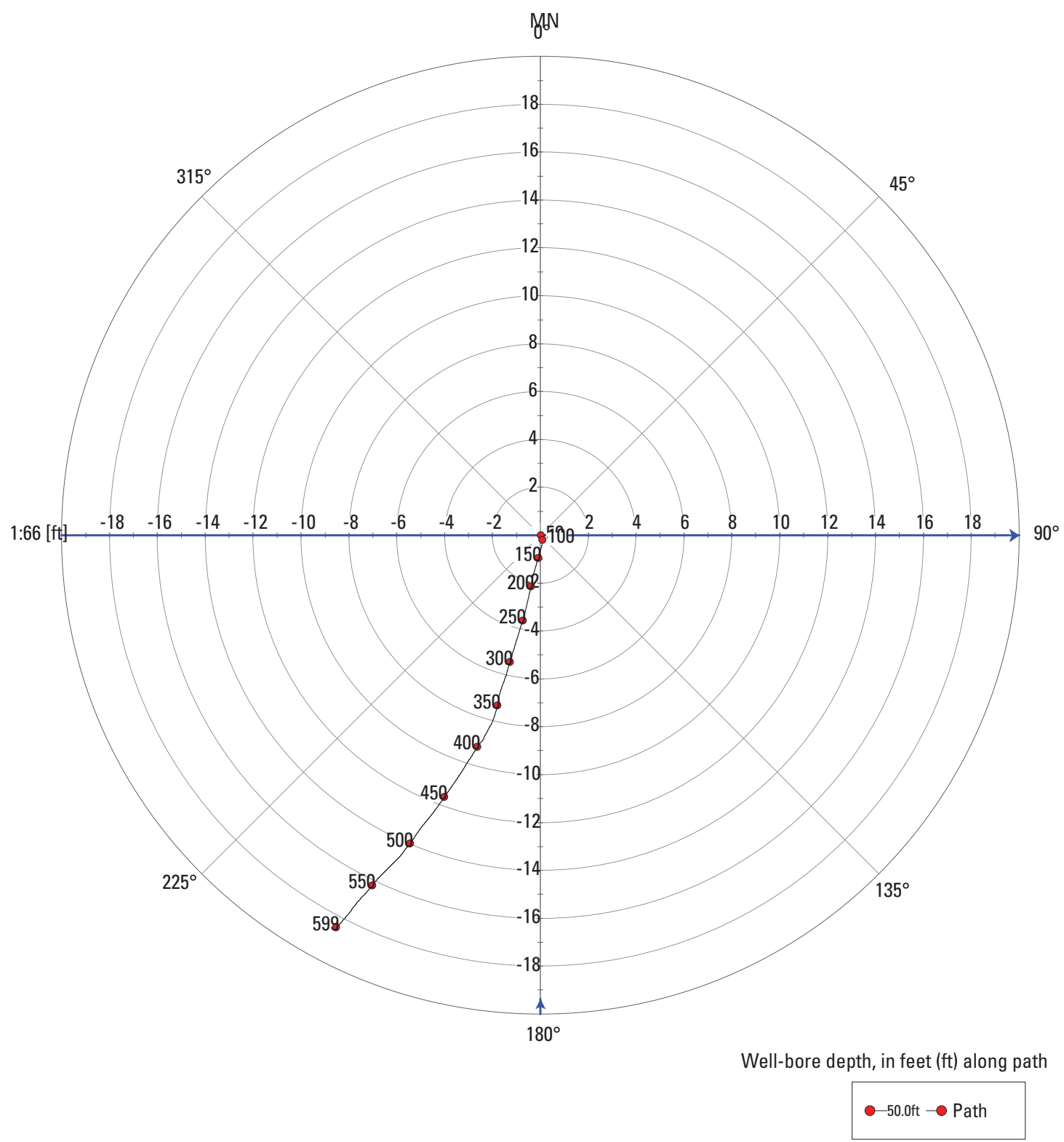

Figure 2.12. Interpretation of well-bore drift (path) as determined from orientation data collected with acoustic televiewer logs for well BK-3067. Direction of path in degrees relative to magnetic north (MN) and deviation from vertical in feet (ft) shown at selected depths. Top of borehole at center of plot. Path of borehole shown at 50 -foot depth intervals. 


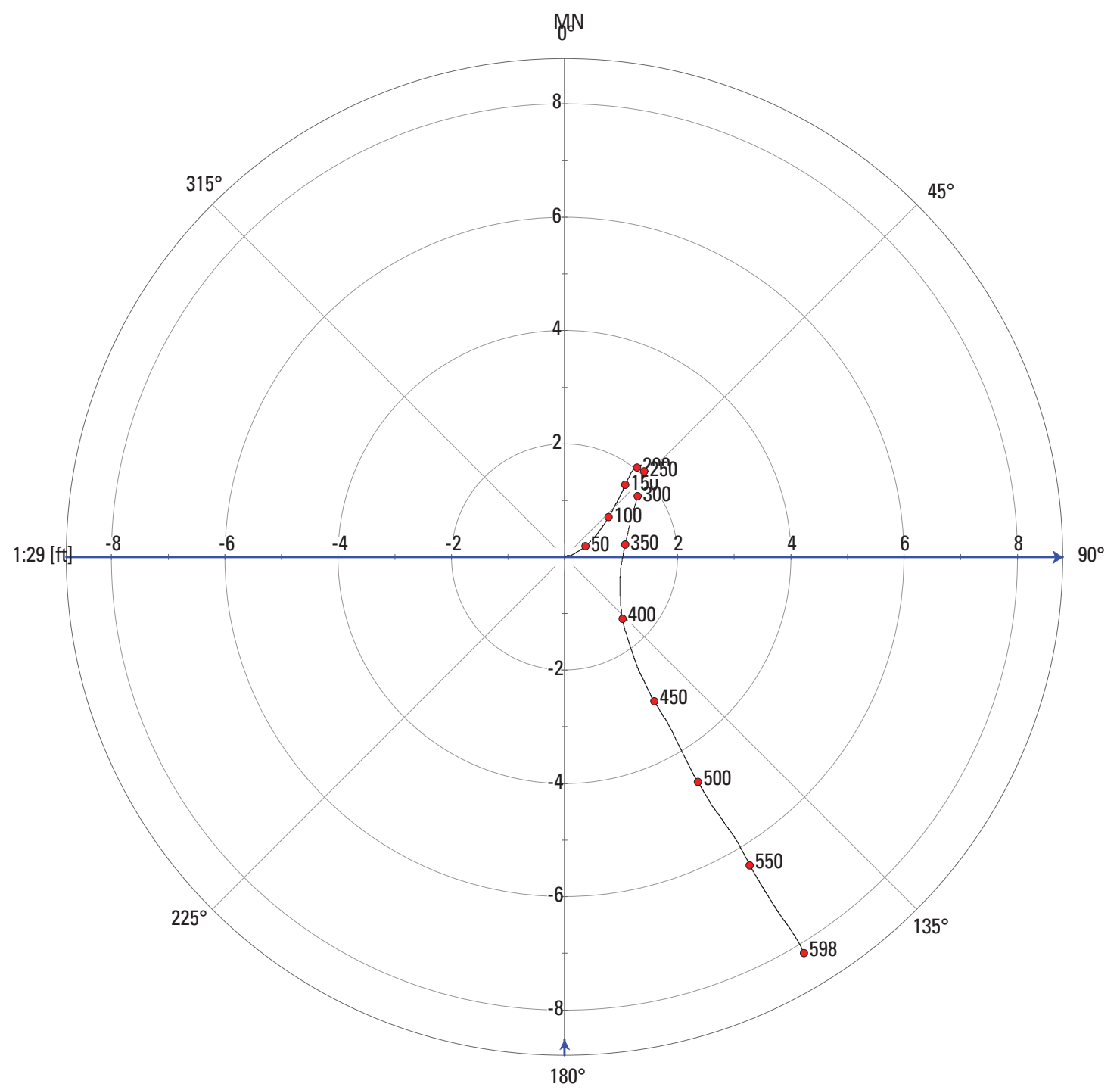

Well-bore depth, in feet (ft) along path

$-50.0 \mathrm{ft} \rightarrow$ Path

Figure 2.13. Interpretation of well-bore drift (path) as determined from orientation data collected with acoustic televiewer logs for well BK-3068. Direction of path in degrees relative to magnetic north (MN) and deviation from vertical in feet (ft) shown at selected depths. Top of borehole at center of plot. Path of borehole shown at 50-foot depth intervals. 


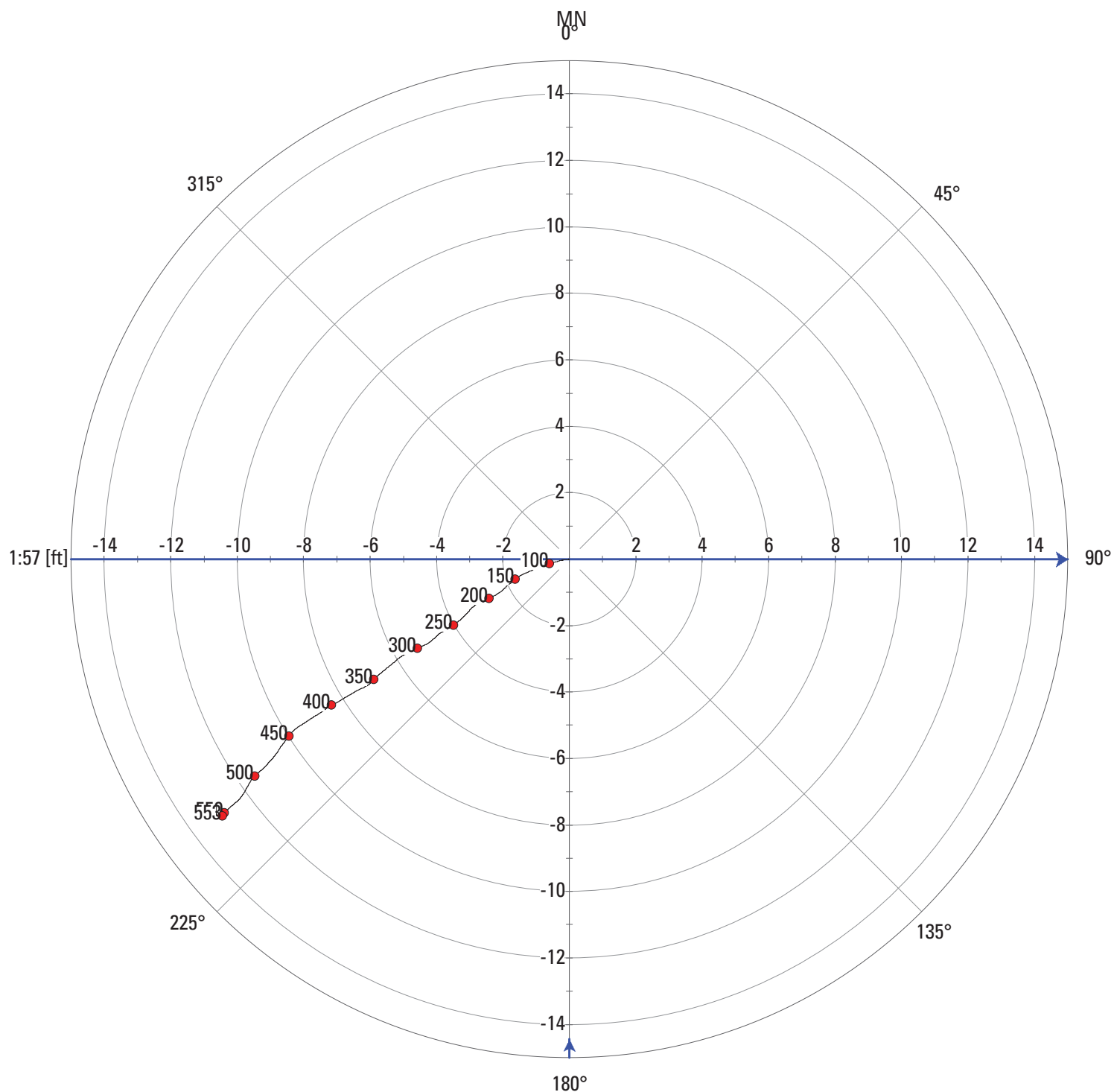

Well-bore depth, in feet (ft) along path

$-50.0 f t \rightarrow$ Path

Figure 2.14. Interpretation of well-bore drift (path) as determined from orientation data collected with acoustic televiewer logs for well BK-3070. Direction of path in degrees relative to magnetic north (MN) and deviation from vertical in feet (ft) shown at selected depths. Top of borehole at center of plot. Path of borehole shown at 50-foot depth intervals. 


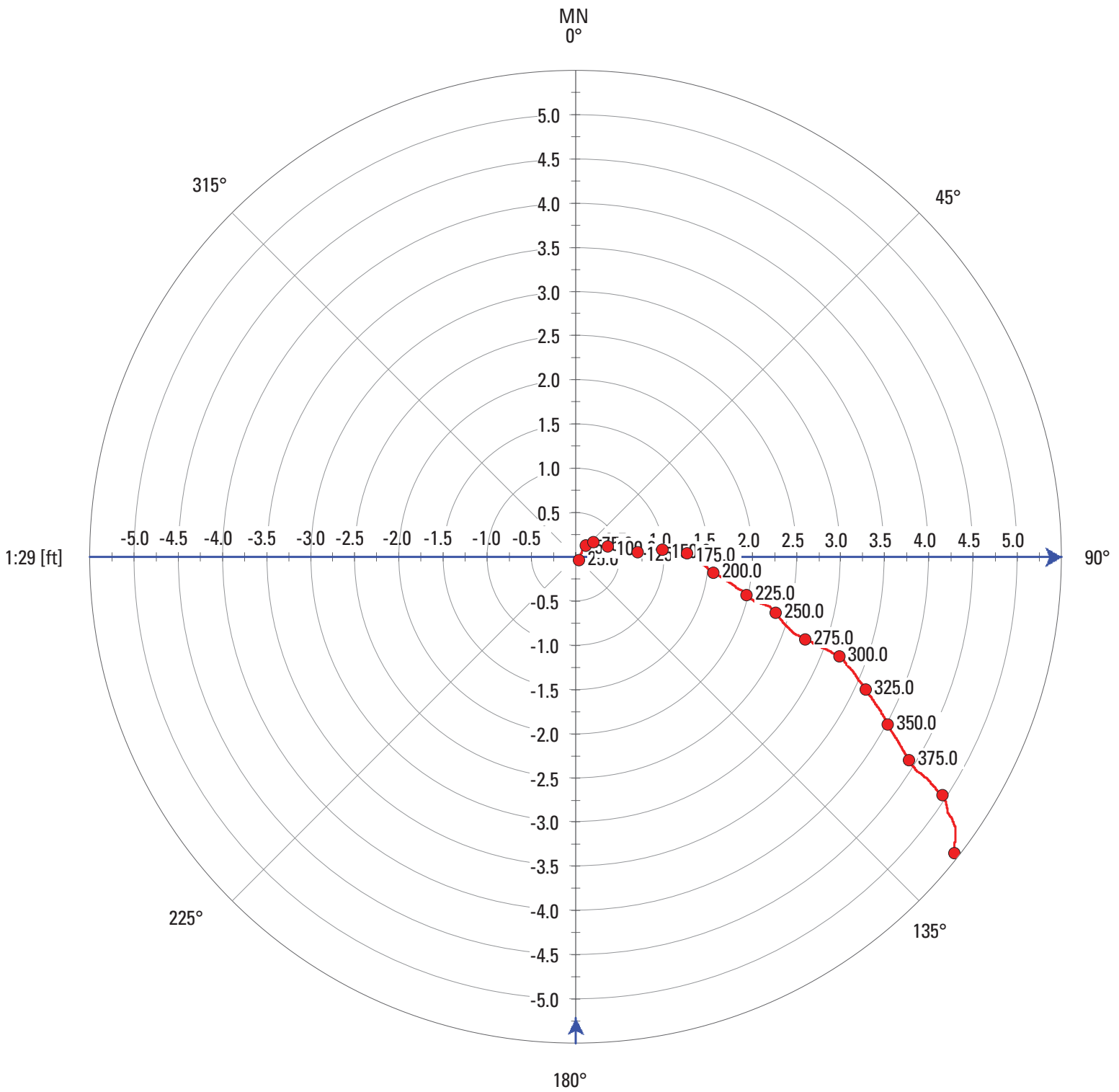

Well-bore depth, in feet (ft) along path

$$
-25.0 f t \rightarrow \text { Path }
$$

Figure 2.15. Interpretation of well-bore drift (path) as determined from orientation data collected with acoustic televiewer logs for well BK-3071. Direction of path in degrees relative to magnetic north (MN) and deviation from vertical in feet (ft) shown at selected depths. Top of borehole at center of plot. Path of borehole shown at 25-foot depth intervals. 
For additional information, contact:

Director, Pennsylvania Water Science Center U.S. Geological Survey

215 Limekiln Road

New Cumberland, PA 17070-2424

Or visit our website at: https://www.usgs.gov/centers/pa-water

Publishing support provided by the U.S. Geological Survey Science Publishing Network, West Trenton Publishing Service Center. 

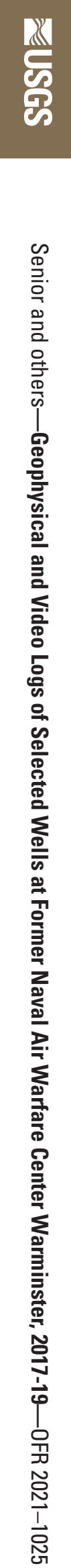